FLÁVIO APRO

FOLIAS DE ESPANHA: O ETERNO RETORNO

SÃo PAULO

2009 
APRO, FLÁVIO. FOLIAS DE ESPANHA: O ETERNO RETORNO

"Dados Internacionais de Catalogação-na-Publicação (CIP)"

(Biblioteca Setorial - UEM. Nupélia, Maringá, PR, Brasil)

Apro, Flávio, 1973-

Folias de Espanha : o eterno retorno / Flávio Apro. -- São Paulo, 2009

A654f $241 \mathrm{f}$ : : il. (algumas color.) +1 DVD

Tese (doutorado em Música)--Universidade de São Paulo, Escola de Comunicação e Artes, 2009.

Orientador: Prof. Dr. Eduardo Seincman.

1. Folias de Espanha - Música instrumental barroca - Temas - Séc. XVIII. 2. Música instrumental barroca - Portugal - Séc. XVI. 3. Violão - Temas e variações. I. Universidade de São Paulo. Escola de Comunicação e Artes. Programa de PósGraduação em Música.

CDD 22. ed. - 784.181248 NBR/CIP - 12899 AACR/2 
FLÁVIO APRO

\title{
FOLIAS DE ESPANHA: O ETERNO RETORNO
}

\author{
Tese apresentada ao Programa de Pós-Graduação em Música \\ da Escola de Comunicações e Artes da USP, como requisito parcial \\ para obtenção do título de Doutor em Música, \\ sob a orientação do Prof. Dr. Eduardo Seincman.
}

SÃO PAULO 
APRO, FLÁVIO. FOLIAS DE ESPANHA: O ETERNO RETORNO

\section{FLÁVIO APRO}

"Folias de Espanha: o eterno retorno"

Tese de Doutorado

Requisito parcial para conclusão do curso de Doutorado

Escola de Comunicacoes e Artes - USP

Área de concentração: Musicologia

Linha de pesquisa: História, Estrutura e Estilo na Música

Aprovado em

BANCA EXAMINADORA: 


\section{AGRADECIMENTOS}

Agradeço ao professor ALBERTO IKEDA pela preciosa contribuição acadêmica que vem desde o mestrado até a qualificação e defesa desta tese; ao violonista ANTHONY GLISE pela generosidade em compartilhar sua música e seus pensamentos originais sobre o tema da pesquisa; ao professor e flautista BERHARD FUCHS pelas traduções do alemão; ao acadêmico DAVI NERY ROCHA que auxiliou coletando e selecionando informações em seu trabalho de iniciação cientifica; ao compositor e diretor de teatro EDUARDO MONTAGNARI pela leitura atenta e revisão textual; ao professor e compositor EDUARDO SEINCMAN pela generosa orientação e experientes conselhos; ao violonista GILSON UEHARA ANTUNES por alguns auxílios emergenciais e pelo incentivo permanente; à pesquisadora GIULIA TETTAMANTE por compartilhar textos importantes; ao violonista LUIGI ATTADEMO que foi uma das fontes de inspiração para esse trabalho e pelo envio de gravações e textos; à bibliotecária MARIA SALETE RIBELATTO ARITA pelo auxílio na elaboração da ficha catalográfica; à professora MÔNICA ISABEL LUCAS que apresentou o universo da retórica musical antiga de forma apaixonada e iluminadora; ao colecionador PAUL GABLER pelo colossal trabalho de divulgação da Folias e pela generosidade em compartilhar materiais raros; ao professor e compositor RAEL BERTARELLI GIMENES TOFFOLO pela leitura atenta e conselhos pontuais; à dançarina e pesquisadora RAQUEL DA SILVA ARANHA pelos esclarecimentos sobre o universo da dança; ao professor e pesquisador REED HOYT pelo envio de seu texto; ao professor e musicólogo ROGÉRIO BUDASZ pelo envio de sua tese; ao professor e musicólogo RUY VIEIRA NERY que dispendeu seu tempo em conversas esclarecedoras; à professora SONIA ALBANO DE LIMA pelo incentivo inicial e contribuição acadêmica desde o mestrado; ao professor e alaudista STEFANO MENGOZZI pela confiança no envio de seu material inédito; e à VANIA MALAGUTTI FIALHO pela compreensão e auxílio profissional.

Esta tese está dedicada à minha esposa KELLY RAMOS, que por alguns anos teve de dividir seu tempo com a elaboração deste trabalho. 


\section{RESUMO}

Esta tese focaliza a trajetória do tema musical Folias de Espanha, que constitui um dos mais notáveis fenômenos na musicologia devido à sua permanente recorrência na História da Música. Nosso objetivo foi ampliar o escopo interdisciplinar de estudo e de reflexão musicológica através da compreensão da utilização do tema na História da Música e sua historiografia, a fim de enriquecer o horizonte de nossa prática acadêmica. A Folias de Espanha é uma melodia simples e de caráter enigmático que surgiu em Portugal no início do século XVI como uma dança selvagem popular das ruas que teve sua estrutura rítmica e harmônica modificadas ao passar pela Espanha. Da península ibérica, migrou para a Itália e foi levada por guitarristas italianos à corte francesa, transformando-se ali em uma dança majestosa. Sua história a partir desse itinerário é complexa e reflete sua grande popularidade, pois ela ainda constitui grande fonte de inspiração para diversos compositores, desde nomes consagrados como Bach, Beethoven e Liszt, até trilhas compostas para filmes comerciais. Outros temas musicais apresentam a mesma recorrência histórica, como por exemplo, o hino católico Dies Irae do século XIII ou o tema do Capricho N.24 de Paganini, mas a retomada da Folias de Espanha como tema musical é a mais recorrente na História da Música.

Palavras-chave: Folias de Espanha, Tema e Variações, Violão, História da Música, Artes. 


\begin{abstract}
This thesis focuses on the trajectory of the theme Spanish Folias, which is one of the most remarkable phenomena in musicology due to its permanent recurrence in music history. Our goal was to broaden the scope of interdisciplinary study and musicological reflection through the understanding of the use of the theme in music history and its historiography, in order to enrich the horizon of our academic practice. The Spanish Folias is a simple melody with enigmatic character that first appeared in Portugal in the early sixteenth century as a wild popular street dance that had its rhythmic and harmonic structure modified by passing through Spain. From the Iberian Peninsula, it traveled to Italy and was taken by Italian guitarists to the French court, becoming into a majestic dance. Its history starting from this itinerary is complex and reflects its great popularity, since it still constitutes a great source of inspiration for several composers, since renowned names such as Bach, Beethoven and Liszt, until soundtracks composed for commercial movies. Other musical themes display the same historical recurrence, as for example, the XIII century catholic hymn Dies Irae or Paganini's Caprice N.24, but the resuming of Spanish Folias as musical subject is the most recurrent in the History of Music.
\end{abstract}

Keywords: Spanish Folias, Theme and Variations, Spanish Guitar, History of Music, Arts. 
APRO, FLÁVIO. FOLIAS DE ESPANHA: O ETERNO RETORNO

Só pode ser eterno aquilo que está fora do tempo.

Richard Wagner (1879) 


\section{SUMÁRIO}

INTRODUÇÃO

CAPÍTULO 1: ORIGENS IBÉRICAS DE UMA IDÉIA MUSICAL PERENE

1.1 Contexto sócio-cultural da Europa moderna 12

1.2 Portugal: primórdios de uma tradição popular na Literatura e na Dança _ 18

1.3 Espanha: diáspora da Folia pela península ibérica ___ 23

1.4 Possíveis transformações do ground Folia em acompanhamento ___ 34

1.5 A Folia chega à Itália __ 38

1.6 Conexões com o surgimento da guitarra barroca ___ 43

1.7 A Folia ascende às cortes da França e Inglaterra __ 51

CAPÍTULO 2: APOGEU DE UM PATRIMÔNIO UNIVERSAL DA ARISTOCRACIA

2.1 Contexto retórico na música dos séculos XVII e XVIII __ 57

2.2 A tópica da loucura nas artes _ 60

2.3 Considerações sobre os afetos da Folias de Espanha na música antiga __63

2.4 Afinidades entre a retórica e a forma tema e variações __ 68

2.5 Auge da popularidade em variações virtuosísticas ___ 71

2.6 Sarabande de Haendel: Folias de Espanha?___ 80

2.7 Bauernkantate de Bach: uma paródia setecentista __ 90

2.8 Declínio da Folias de Espanha no Classicismo __ 104

CAPÍTULO 3: RUÍNAS DE UM PASSADO GLORIOSO

3.1 Renovação da forma Tema e Variações nos séculos XVIII e XIX _ 110

3.2 Folias de Espanha em Beethoven: discurso e temporalidade___ 114

3.3 A época de ouro da guitarra romântica _ 133

3.4 Alguns ecos da tradição no Romantismo __ 148

CAPÍTULO 4: RESSURGIMENTO NO SÉCULO XX

4.1 Paródia no Modernismo 167

4.2 Interdisciplinaridade: a Folias de Espanha no cinema

4.3 Pós-Modernidade e as novas sonoridades da Folias de Espanha ___ 208

4.4 Pastiches neobarrocos da Folias de Espanha __ 215

CONSIDERAÇÕES FINAIS ___ 222

REFERÊNCIAS BIBLIOGRÁFICAS___ 228

\section{DVD ANEXO}

- Anexos (tabela de compositores, estatística de obras, árvore genealógica, lista de gravações, tradução da Bauernkantate BWV 212)

- Áudio (álbuns, compositores, midi)

- Bibliografia (artigos, partituras, teses) 


\section{INTRODUÇÃO}

Folias de Espanha é um caso atípico na história das artes. Não se trata de uma imensa pintura histórica nem de um extenso épico literário. Apenas um breve e misterioso tema musical com duração de menos de um minuto, mas que representa um dos casos mais interessantes de imanência e resistência conhecidos. Imanente, pois permanece há mais de quinhentos anos soando nos ouvidos dos mais variados compositores, intérpretes e ouvintes. Resistente porque talvez tenha sido o único tema musical a não desaparecer frente às incessantes transformações estéticas e estilísticas que corromperam e aniquilaram as mais importantes e tradicionais estruturas consolidadas no decorrer da história da música. Traçar o percurso desta fascinante história é a proposta deste trabalho.

O termo folia é de origem francesa e significa loucura, capricho. A maioria dos estudiosos sobre o tema, como o musicólogo norte americano Richard Hudson - um dos maiores pesquisadores sobre o tema - costuma adotar a terminologia Early Folia e Late Folia que, em português, traduzir-se-ia por algo como Folia "anterior" e "posterior", mas preferimos, por razões práticas e de especificidades da língua portuguesa, denominá-las neste trabalho simplesmente como Folia - a fim de ressaltar sua origem popular ibérica - e Folias de Espanha - para associá-la ao ambiente aristocrático francês em que o tema se transformou, sempre em itálico. No fundo, podemos pensar em um tipo ibérico e outro francês, pois sua trajetória geográfica, conforme veremos, inicia-se em Portugal e Espanha, passa pela Itália como eixo, e desemboca na França espalhando-se por toda a Europa.

Nosso interesse em pesquisar esse tema iniciou-se no ano de 1997, a partir da observação do repertório violonístico e da recorrência do tema atravessando um período muito extenso na história do instrumento. Alguns anos mais tarde, por volta de 2000, iniciamos nossa pesquisa de maneira informal, após algumas pesquisas via internet, que 
nos levou a travar contato com a impressionante homepage do colecionador holandês Paul Gabler, intitulada La Folia, a Musical Cathedral. Essa página contém um enorme acervo fonográfico sobre a Folias de Espanha, além das mais importantes referências bibliográficas. Nela estão reunidas centenas de informações sobre a história fonográfica da Folias de Espanha, com compilações dos libretos de CDs, fotos digitalizadas das capas de discos e partituras, bem como uma ampla disponibilização dos incipts e de arquivos em áudio mp3 e midi, que permitem ao usuário explorar o universo sonoro dessa produção e formar um quadro de referência bastante completo sobre a temática - embora tivéssemos de usar alguns filtros para esta tese ao separar informações importantes de meras opiniões pessoais. Foi o passo definitivo para nosso comprometimento em transformar a curiosidade em um futuro tema de pesquisa, que não foi empreendido durante o mestrado justamente pelo fato de uma maior exigência de fôlego e da necessidade de um amadurecimento maior enquanto pesquisador.

Consideramos que a espera foi produtiva, pois tivemos a oportunidade de recolher uma quantidade maior de material para a pesquisa, além de termos adquirido maior experiência na área metodológica, o que nos propiciou evitar diversos erros recorrentes em trabalhos acadêmicos, o que poderia comprometer o resultado de uma pesquisa tão complexa. Um desses vícios acadêmicos é justamente acreditar que um modelo historiográfico baseado na análise seja suficiente para sustentar um raciocínio mais aprofundado sobre uma determinada temática. Não nos cabe emitir juízo de valor em relação a tal procedimento, porém o simples fato de termos utilizado poucas análises apenas para revelar aspectos relevantes sobre a obra focalizada - dispensa maiores esclarecimentos. 
Preferimos adotar a estratégia de travar diálogos com as disciplinas auxiliares da História Social, Retórica e Estética, tendo sempre em vista trazer à cena uma contextualização histórica que justifique o desenvolvimento do tema focalizado. Nosso modelo historiográfico inverteu a relevância dos papéis entre o sujeito histórico (autores e compositores) - relegado ao segundo plano, o que justifica a quase total ausência de biografias - e o objeto (as obras) - sempre focalizado como elemento preponderante. A História da Música poderia ser ilustrada por meio de outros referenciais que não biográficos, estéticos ou crítico-opinativos, revelando aspectos mais intrínsecos à sua natureza. O próprio tema Folias de Espanha poderia ser um excelente fio condutor histórico. Essa mudança de hierarquia historiográfica também gerou a necessidade de estabelecer relações correspondentes dentro do contexto social (como os aspectos exteriores influenciaram os casos específicos) e seu reverso (como os casos específicos retroalimentaram as culturas locais). Desta forma, essa tese propõe uma abordagem pouco explorada na área musicológica, que é traçar a história do objeto ao invés de destacar os prodígios de determinados "heróis". Neste trabalho, a música é sempre mais importante que seu autor, se é que ele existe.

A principal questão que despertou nosso interesse pela pesquisa sobre história da Folias de Espanha foi seu "eterno retorno", ou seja, seu constante reaparecimento somando mais de três séculos de história e adaptando-se às mais diferentes estéticas e poéticas. Partindo dessa constatação, decidimos investigar quais os fatores que determinaram essa flexibilidade e longevidade, fazendo dessa questão o problema central de nossa pesquisa.

Diversos pesquisadores vêm se debruçando sobre a questão da Folias de Espanha na História da Música há mais de um século, e costumam adotar o ponto de vista de que o uso constante desse tema é um tipo de produção coletiva e não-individualizada, ou seja, um 
mero produto que misteriosamente permanece em algumas culturas. Tal constatação nos pareceu insuficiente e nos instigou a levantar uma série questionamentos que procuramos responder ao longo da tese: a) O que é, de fato, a Folias de Espanha?; b) Onde ela está e onde não está?; c) Quem e onde a executavam?; d) Por que a Folias de Espanha, de origem popular, começou a ser escrita?; e) Quais as modificações que o tema sofreu?, f) Qual o contexto sócio-cultural da Folias de Espanha?; g) Seria o tema de fato a expressão de uma coletividade ou uma mera apropriação de uma prática popular pela cultura dominante?

Nossa hipótese inicial estava direcionada à idéia da "geometrização do tempo" presente, por exemplo, na música polifônica, que proporciona no ouvinte a sensação de flutuação no tempo, versus a criação da narrativa temporal nas formas clássicas e na harmonia tonal, onde existe uma "construção horizontal" do tempo. A longevidade da Folias de Espanha e o seu uso constante na forma Tema e Variações parecia apontar para a questão filosófica do Tempo Mítico, que poderia ser uma resposta à questão do motivo de seu constante reaproveitamento como ponto de partida para inúmeras variações. Entretanto, a pesquisa, a leitura e a comparação de materiais musicais e teóricos revelaram que esse aspecto era parcialmente correto, mais precisamente uma das conseqüências do que propriamente a causa da perenidade histórica. Os fatores que determinaram sua imanência são muito mais práticos e múltiplos do que estéticos e unívocos.

Embora a Folias de Espanha seja uma melodia bastante conhecida do repertório de diversos instrumentistas, especialmente entre os violonistas, ainda não há trabalhos sobre esse tema publicados no Brasil - tampouco encontramos obras escritas por compositores brasileiros que utilizassem esse tema. Uma pesquisa bibliográfica inicial no catálogo RILM (Répertoire International de Littérature Musicale / Abstracts of Music Literature) apontou 
a existência de apenas uma dissertação na França ${ }^{1}$, alguns artigos em periódicos internacionais, verbetes de dicionários (sobretudo os espanhóis) e vários livros e artigos publicados por Richard Hudson, além do verbete que este mesmo pesquisador publicou no The New Grove Dictionary. No que se refere à temática da Folias de Espanha propriamente dita, estendemos a pesquisa à localização de diversos artigos disponíveis em periódicos e livros relacionados ao assunto, e efetuamos uma revisão historiográfica completa que, aos poucos, foi se expandindo até formar um quadro completo sobre sua trajetória, evolução e historicidade.

O uso da internet como veículo de investigação bibliográfica foi decisivo para a pesquisa de fontes primárias e secundárias: ela representa, hoje, uma indispensável ferramenta de trabalho, especialmente para aqueles que vieram da era do livro impresso. $\mathrm{O}$ acesso a edições de livros antigos (Google Books, Biblioteca Nacional de Portugal), artigos especializados em revistas de música (Oxford Music Online, JSTOR) e teses online de universidades contribuíram enormemente para a consolidação de uma bibliografia abrangente, trazendo uma quantidade surpreendente de informações que dificilmente seriam reunidas em tão pouco espaço de tempo em outras épocas.

A tese está dividida em quatro capítulos, cobrindo dois ciclos de grande representatividade da Folias de Espanha: um que se inicia no século XV, atinge seu auge no início do XVIII e decai no final do mesmo; outro que ressurge a partir do início do século XX e segue em linha ascendente até os dias atuais.

O primeiro capítulo trata das origens ibéricas de uma idéia musical que se tornaria permanente na história, focalizando inicialmente o contexto sócio-cultural da Europa pósmedieval, seguindo com os primórdios da Folia enquanto tradição popular na literatura e na

\footnotetext{
${ }^{1}$ RAYNAL, 1993.
} 
dança em Portugal, avançando na Espanha com sua diáspora pela península ibérica, as possíveis transformações do ground em acompanhamento, sua chegada à Itália, suas conexões com o surgimento da guitarra barroca e sua ascensão às cortes da França e Inglaterra. A Folia era, pelo menos até a década de 1670, uma dança muito rápida e tumultuada, na qual dançarinos carregavam homens vestidos de mulheres sobre seus ombros, que literalmente enlouqueciam ao som do ritmo barulhento e vibrante. Apesar de existirem vários temas básicos semelhantes, não existia ainda um traço melódico unificado. Por meio da adaptação do ritmo e fixação da melodia em uma espécie de passacaglia solene, a Folias de Espanha foi fixada em seu arquétipo clássico por Jean Baptiste Lully em 1672 na forma de uma melodia de dezesseis compassos disposta em uma simples progressão harmônica, adquirindo popularidade instantânea. Outros compositores barrocos que compuseram versões importantes foram Arcangelo Corelli (1700) e Georg Friederich Haendel (1727). A moldura harmônica da Folias de Espanha costuma ser apresentada no tom de Ré menor: Dm | A7 | Dm |C | F |C | Dm | A7 | Dm | A7 | Dm |C |F |C | Dm A7 | $\operatorname{Dm} \|$

É impossível determinar a origem deste tema musical: alguns sustentam ter sido Gaspar Sanz quem inaugurou o tema original da famosa Folias de Espanha, em 1674, porém outros autores destacam uma importante contribuição anterior do também guitarrista Francesco Corbetta, em 1671. Enquanto alguns atribuem grande importância histórica a Andrea Falconieri, que, em 1650, publicou uma Folia com todos os traços conhecidos, outros garantem que o violinista inglês Michel Farinel foi o legítimo fundador do tema. Para dificultar ainda mais a localização de sua origem, a progressão de acordes da Folia já é reconhecível no Fitzwilliam Virginal Book, como parte de uma melodia anônima intitulada Pakington's Pownde, podendo-se retroagir sua criação ao ano de 1618. Levando- 
se em consideração que o empréstimo temático era uma prática comum na música do século XVII, é quase impossível determinar quem escreveu primeiro ou quem a tomou emprestada. Por essa razão, elaboramos uma "árvore genealógica" que nos permitiu identificar linhagens de relações temáticas por meio de semelhanças e diferenças entre as obras estudadas.

O capítulo seguinte retrata o apogeu da Folias de Espanha como um patrimônio universal da aristocracia, iniciando-se com o contexto retórico na música dos séculos XVII e XVIII, que aborda a questão da tópica da loucura nas artes, levanta considerações sobre os afetos na música antiga, mostra as afinidades entre a retórica e a forma Tema e Variações. A abordagem retórica prossegue relatando seu auge de popularidade em variações virtuosísticas, analisando alguns casos específicos, como a famosa Sarabande de Haendel e a Bauernkantate de Bach, e finalizando o capítulo com o declínio da Folias de Espanha no Classicismo. Devido ao fato do tema ter sido amplamente explorado durante o século XVII, dedicamos uma parte de nosso estudo à questão da retórica musical, a fím de compreendermos o contexto histórico-cultural em que esse tema musical se inseriu e aprofundamos, dessa forma, o entendimento do fenômeno de permanência da Folias de Espanha dentro da História da Música.

Existe uma estreita relação da Folias de Espanha com a sarabanda cortesã oitocentista devido à ênfase no segundo tempo em figura pontuada, seu andamento lento e seu ethos solene. A progressão harmônica, acima descrita, era recorrente em algumas danças do final do século XVII, além do tema que estamos focalizando. Há traços comuns entre a Folia e a Folias de Espanha: ambas em compasso ternário, semelhanças entre os períodos finalizando na meia-cadência na região da dominante. 
O fato é que ela surgiu a partir de tradições populares pré-existentes, e que a contribuição de Lully costuma ser superestimada. Entenda-se como tradições populares aquelas oriundas de uma classe social não cortesã: no teatro quinhentista, a Folia estava associada às personagens populares (pastores, camponeses) que executavam cantos e danças com energia, identificando sua natureza social para a platéia, ou também na celebração de um alegre desfecho. Foi então a partir dessa "consagração" pelo diretor musical da corte de Luís XIV que se estabeleceria uma tradição historiográfica que inspiraria muitos compositores até o presente, sobre a qual escrever-se-iam milhares de variações, numa diversidade que abrange desde simples versões para harpa solo até variações para orquestra sinfônica² ${ }^{2}$.

Considerando que a presença da Folias de Espanha na música instrumental é bem conhecida, verificamos que o uso retórico de sua melodia para acompanhar poesia permanece largamente inexplorado. O conteúdo da tese é, na melhor das hipóteses, apenas um ponto de partida que promete uma investigação fascinante. $\mathrm{O}$ fato dessa melodia ter sido tão utilizada na poesia leva a concluir que uma parcela muito maior da população estava familiarizada com ela do que o mais restrito círculo de instrumentistas profissionais e amadores. Outrossim, um estudo sobre os textos específicos que foram cantados sobre a Folias de Espanha poderá revelar algo sobre a gama de significados afetivos e simbólicos veiculados pela melodia em si.

Os capítulos 3 e 4 podem ser considerados um bloco único em razão de abordarem o segundo ciclo histórico da Folias de Espanha, com as ruínas de um passado glorioso e seu ressurgimento no século XX. Neles, veremos a renovação da forma Tema e Variações nos

\footnotetext{
${ }^{2}$ Maxime Eilander: Folia Variations for harp solo (2004); Antonio Salieri: XXVI Variazoni sull'aria La Follia di Spagna.
} 
séculos XVIII e XIX, o uso do tema feito por Beethoven na $5^{a}$ Sinfonia como um recurso discursivo e temporal, a época de ouro da guitarra romântica e os ecos da tradição no Romantismo. O bloco final trará uma discussão sobre a paródia no Modernismo, estendendo-se à Pós-modernidade e às novas sonoridades da Folias de Espanha, seu uso interdisciplinar no cinema e os pastiches neobarrocos dos dias atuais. Estes capítulos relatam que a Folias de Espanha caiu em desuso em meados do século XIX, reaparecendo na década de 1930 com as variações de Sergei Rachmaninoff e Manuel Ponce. A partir de então, o tema voltou a ser revisitado intensamente nas décadas seguintes, resgatando sua popularidade entre os compositores do setor erudito, e somando-se a uma impressionante trajetória histórica de aproximadamente 330 anos e mais de 150 compositores. Outros temas musicais apresentam semelhante recorrência histórica, como por exemplo, o tema do Capricho N.24 de N. Paganini, Carnaval de Veneza, ou maior ancestralidade como a Jota Aragonesa. No entanto, a retomada da Folias de Espanha como tema musical é indisputavelmente maior.

Uma dificuldade que não se dissipou tão rapidamente refere-se aos diferentes tipos de Folias de Espanha. Poderíamos mencionar pelo menos três modalidades que costumam confundir os intérpretes: a) as Folias cujo título e seu conteúdo (melodia, harmonia e ritmo) são autenticamente o tema famoso: por exemplo, as variações La Folia (1700) de Corelli; b) as "Folias" apenas no título, cujo conteúdo foge do esquema que será delineado no trabalho: por exemplo, a peça Les Folies françoises (1722) de François Couperin; c) as que são de fato Folias de Espanha em seu conteúdo, mas não no título: por exemplo, a Sarabande (1727) de Haendel. As "Folias" do segundo tipo não foram examinadas ao longo da tese, embora Paul Gabler faça uma distinção arbitrária entre os três tipos, incluindo forçadamente certos exemplos que não respondem a todos os atributos (de 
Paganini a Britney Spears), e ignorando obras inequívocas como as de Alonso Mudarra, Johannes Brahms e Maurice Ohana. Outro caso que não será abordado neste trabalho é a possível conexão entre as origens portuguesas do tema e a tradição da festa de Folia de Reis brasileira, cuja relação pode ser traçada a partir do domínio da cultura popular lusitana: deixaremos essa temática como outra sugestão para uma futura investigação nos campos da antropologia ou da etnomusicologia.

Os materiais bibliográficos, fonográficos e estatísticos resultantes da pesquisa são extremamente reveladores e servem não apenas como material de apoio à tese, mas como contraponto, uma vez que carregam uma importância equivalente ao trabalho desenvolvido, pois nos limitamos a selecionar trechos de obras para discutir determinados aspectos em estudo no desenrolar do texto. Assim, uma consulta aos materiais anexos digitalizados - as gravações, a tabela de compositores, o gráfico com a estatística de obras dispostas cronologicamente, e, sobretudo, a árvore genealógica resultante da pesquisa - poderá até mesmo evidenciar novos aspectos sobre a Folias de Espanha.

O empreendimento desta pesquisa foi ambicioso, porém estamos seguros de que nossa meta - levantar alguns problemas conceituais e abrir um horizonte de respostas que, longe de eliminar o assunto, descortinasse um campo de possibilidades de futuros estudos foi plenamente alcançada. Assim, o desafio proposto de dialogar com diversas teorias não causou dispersão, mas serviu para aumentar nossa intuição e atitude investigativa, pois constatamos que a teoria por si própria não é suficiente para responder aos complexos e esquivos problemas da Arte. Procuramos também evitar o perigo de estabelecer classificações estanques que ignorassem a multiplicidade de um fenômeno tão rico e complexo como a Folias de Espanha. 
CAPÍTULO 1:

ORIGENS IBÉRICAS DE UMA

\section{IDÉIA MUSICAL PERENE}




\subsection{Contexto sócio-cultural da Europa moderna}

Após o declínio das Cruzadas, no final do século XIII, a população européia testemunhou uma notável transformação histórica: a enfraquecimento do poder da Igreja e o surgimento do estado absolutista, ou seja, a centralização política e econômica foi transferida aos reis, com o apoio dos comerciantes burgueses. Além disso, as Cruzadas estimularam o intercâmbio econômico e cultural com o Oriente Médio, resultando num efeito estimulante para a cultura ocidental que, de certa forma, preparou o caminho para o Renascimento.

Em Portugal, o absolutismo passou por várias fases no sentido do aumento de autoridade e concentração de poder nas mãos dos reis. A Espanha conheceu a unificação política através do casamento da rainha Isabel de Castela com o rei Fernando de Aragão em 1469. Na Inglaterra, o absolutismo teve início em 1509 com Henrique VIII, que apoiado pela burguesia, ampliou os poderes monárquicos, diminuindo os do parlamento. $\mathrm{O}$ processo de centralização do poder monárquico na França atingiu seu ponto culminante com Luís XIV, que reinou entre 1643 e 1715.

Desse modo, o absolutismo fez com que as grandes cortes européias passassem a assumir a liderança da vida cultural e artística de seus domínios territoriais. A classe aristocrática passou a seguir um complexo código social que determinava parâmetros que abrangiam desde o comportamento cotidiano até a etiqueta cortesã, incluindo o perfeito domínio dos princípios da música instrumental e vocal, da dança e da poesia.

Diversas manifestações da cultura popular, provenientes de antigas tradições locais, foram incorporadas ao repertório da aristocracia, sofrendo um processo de transformação que as fizeram perder suas características rurais para assumirem novas e elaboradas regras, 
que exigiam um preparo mais cuidadoso, disponível apenas aos membros pertencentes à nobreza.

Porém, essa apropriação não aconteceu de forma unidirecional, mas com trocas recíprocas entre os diversos grupos sociais, dentro do conceito bakhtiniano de Circularidade Cultural. Esse conceito denota o movimento em que as temáticas de origem popular são transmitidas ao ambiente culto por meio de mediadores - como no caso de François Rabelais (1483-1553) - para depois representarem modelos a serem seguidos por toda a sociedade.

Apesar das idéias e da vida cultural serem consideradas produtos exclusivos das classes superiores, sua assimilação pelas classes subalternas é normalmente percebida como algo natural e espontâneo - no sentido ideológico strictu sensu, embora se considere que tal migração acarrete em deterioração e distorção das idéias durante o processo de transmissão. Bakhtin demonstra que o influxo de produtos simbólicos, artísticos inclusive, é recíproco entre as culturas subalterna e hegemônica ${ }^{3}$. Assim, diversos temas musicais, literários e imagéticos foram transformados em "modelos universais" e propagados pelas cortes de maior prestígio para, em seguida, circular por vários países, assumindo traços das culturas locais. Cada corte preservava suas características culturais locais, mesmo quando algum elemento popular era radicalmente transformado em um modelo elitizado ${ }^{4}$.

A partir da mesma chave de raciocínio, Carlo Ginzburg, no prefácio de $O$ Queijo $e$ os Vermes, amplia o conceito da circularidade cultural e nos chama a atenção para o fato de que o discurso da classe subalterna, a partir da escrita transformada em documentos por

\footnotetext{
${ }^{3}$ BAKHTIN, 1999, p. 17-21.

${ }^{4}$ NERY, 2005.
} 
aqueles que detinham o poder da palavra, é incorporado e assimilado pela elite intelectual ${ }^{5}$. A noção de circularidade da cultura nos mostra a dinâmica de movimento na qual, numa dada sociedade, os grupos sociais produzem suas representações, que são assimiladas dialogicamente por outros grupos em um processo de construção de hegemonia e contrahegemonia. No entanto, certas tradições populares mantiveram-se mais próximas de suas origens, enquanto outras foram completamente remodeladas, resultando em algo qualitativamente diferente, conforme demonstraremos ao longo do percurso histórico da Folia.

Estudos recentes sobre tradições musicais na Europa pós-medieval, em particular no Renascimento, demonstram que é impossível associar a música culta apenas com a tradição escrita, pois os tratados de contraponto e improvisação instrumentais dos séculos XVI e XVII revelam que a música não-escrita era também produzida nos ambientes aristocráticos, pois, grande parte da música executada pelos alaudistas, violinistas e tecladistas era improvisada, assim como muito da música vocal elaborada pelas igrejas. Diversos músicos atuavam tanto em praça pública quanto nas cortes. A separação simplista entre os ambientes culto e popular na música renascentista representa uma concepção enganosa, pois, como ressalta o historiador inglês Peter Burke, "se todas as pessoas numa determinada sociedade partilhassem da mesma cultura, não haveria a mínima necessidade de se usar a expressão "cultura popular"”, . Nos séculos XV, XVI e XVII não existia barreira entre a cultura musical popular e de elite. O que existia era um patrimônio compartilhado.

\footnotetext{
${ }^{5}$ GINZBURG, 2007, p.9-26.

${ }^{6}$ BURKE, 1989, p.50.
} 
De acordo com o antropólogo social Robert Redfield existiam, no início da Europa pré-industrial, duas tradições culturais: a "grande tradição" e a "pequena tradição" se de um modelo que aprofunda a questão do movimento recíproco da circularidade cultural, uma vez que oferece uma definição "residual" entre as culturas. Uma definição que não corresponde à divisão clássica povo versus elite e seus respectivos mediadores ou intérpretes - como nas teorias de Bakhtin e Ginzburg - mas aos ambientes de propagação dessas tradições. A grande tradição era transmitida pelas escolas e universidades, nas quais ainda sobrevivia a tradição clássica da filosofia escolástica e teologia medieval, e alguns movimentos intelectuais exclusivos de uma minoria culta, como o Renascimento, o Humanismo, a Revolução Científica do século XVII e o Iluminismo. A pequena tradição vinha representada pelo restante da tradição cultural européia moderna, nas canções e nos contos populares, nas farsas e peças de mistérios, nos folhetos e livros de baladas, etc.

Burke chama a atenção para o fato de que o modelo de Redfield, que foi tomado como ponto de partida em seu estudo da cultura popular na idade moderna, é ao mesmo tempo amplo e restrito, e o reformula considerando:

[...] existiram duas tradições culturais nos inícios da Europa moderna, mas elas não correspondiam simetricamente aos dois principais grupos sociais, a elite e o povo comum. A elite participava da pequena tradição, mas o povo comum não participava da grande tradição. Essa assimetria surgiu porque as duas tradições eram transmitidas de maneiras diferentes. A grande tradição era transmitida formalmente nos liceus e universidades. Era uma tradição fechada, no sentido em que as pessoas que não freqüentavam essas instituições, que não eram abertas a todos, estavam excluídas. Num sentido totalmente literal, elas não falavam aquela linguagem. A pequena tradição, por outro lado, era transmitida informalmente. Estava aberta a todos, como a igreja, a taverna e a praça do mercado, onde ocorriam tantas apresentações.

Assim, a diferença cultural crucial nos inícios da Europa moderna [...] estava entre a maioria, para quem a cultura popular era a única cultura, e a minoria, que tinha acesso à grande tradição, mas que participava da pequena tradição enquanto uma segunda cultura. Esta minoria era anfíbia, bicultural e também bilíngüe. Enquanto a maioria do povo falava apenas o seu dialeto regional e nada mais, a elite falava ou escrevia latim ou uma forma literária do vernáculo, e continuava a saber falar em dialeto, como segunda ou terceira língua. Para a elite, mas apenas

\footnotetext{
${ }^{7}$ REDFIELD apud BURKE, 1989, p.51.
} 
para ela, as duas tradições tinham funções psicológicas diferentes: a grande tradição era séria, a pequena tradição era diversão. Uma analogia contemporânea dessa situação encontra-se na elite anglófona da Nigéria, cuja educação de estilo ocidental não a impede de participar da sua cultura tribal tradicional.

Essa situação não se manteve estática ao longo do período. As classes altas foram deixando gradualmente de participar da pequena tradição, no curso dos séculos XVII e XVIII [...]. (BURKE, 1989, p.55).

Nessas duas tradições, percebemos que o movimento de circularidade não é um fenômeno bilateral, pois enquanto a elite compartilhava da tradição popular, o povo não participava da grande tradição. Assim, as pessoas cultas que tinham acesso à educação e aos textos possuíam uma cultura dupla.

É possível falar na existência de uma pequena tradição na música que as pessoas comuns compartilhavam com os músicos cultos, que não apenas conheciam e praticavam o repertório da tradição oral, mas também os utilizavam em suas composições em gêneros sérios. É de se perguntar até que ponto os músicos cultos propiciaram o fenômeno inverso, trazendo elementos da música da grande tradição aos ambientes da música oral, pois os únicos documentos de que dispomos dessa tradição são as transcrições e os relatos, sendo que o próprio processo de escrita já constitui em si uma interferência intelectual.

Certos elementos da pequena tradição musical, sobretudo a italiana, possuíam conotações locais e regionais, como alguns termos do tipo galliarda milanesa ou tenor di Napoli, porém o conteúdo musical do repertório da tradição oral remanescente em fontes escritas revela procedimentos típicos de uma linguagem internacional. Apesar de muitas cantigas de amor renascentistas compartilharem das mesmas estruturas dos salmos entoados nas igrejas, isto não significa que os instrumentistas improvisadores aprenderam suas técnicas assistindo missas. Os autores de villancicos e romanescas com certeza não adotavam critérios etnomusicólogicos para transcrever fielmente o repertório dos camponeses. Ao contrário, eles sofisticavam as canções e as danças da tradição que 
compartilhavam com as pessoas comuns para dar lugar a uma criação mais refinada, de acordo com critérios estilísticos cultos, gerado a partir da interação entre a pequena e a grande tradição.

Desta forma, a linguagem musical que se desenvolveu no Renascimento por meio da relação entre a pequena e a grande tradição acabou gerando os princípios fundamentais sobre os quais se consolidaria, mais tarde, o estilo Barroco, tais como o pensamento vertical harmônico, as formas binárias e a afirmação da linguagem tonal.

A Folia pode ser considerada como um produto direto desses procedimentos estilísticos e formais herdados do século XVI, que contribuiriam para a formação do novo estilo da música do século XVII. 


\subsection{Portugal: primórdios de uma tradição popular na Literatura e na Dança}

A Folia foi, em sua origem, uma das danças e canções medievais populares da Península Ibérica que se espalharam pela Europa e se transformaram em música polifônica de corte durante o século XVII ${ }^{8}$.

As primeiras referências à Folia provêm de fontes literárias portuguesas entre o final do século XV e início do XVI, sendo que o termo costumava ser associado às manifestações populares que compreendiam dança, canto e baile. A mais antiga parece remontar ao ano de 1490, com as crônicas de Garcia de Resende (1470-1536) sobre o casamento do príncipe Alfonso de Portugal com a princesa católica Isabel de Castilla, ocorrido na cidade de Évora9

Semelhantes descrições a respeito dos bailes e das canções encontram-se em várias peças do poeta e músico Gil Vicente (1465?-1537), tais como O Velho da Orta (1512), Tragicomedia da Serra da Estrela (1527), Auto da Feira (1528), Triunfo do Inferno (1529). No drama litúrgico Auto Sibilla Cassandra (1513), cuja música está perdida, existe uma passagem em que os personagens bíblicos Salomão, Isaías, Moisés e Abraão cantam uma Folia a quatro vozes:

\footnotetext{
${ }^{8}$ NERY, 1998.

${ }^{9}$ RESENDE, apud ESSES, 1992, pp. 636-637.
} 


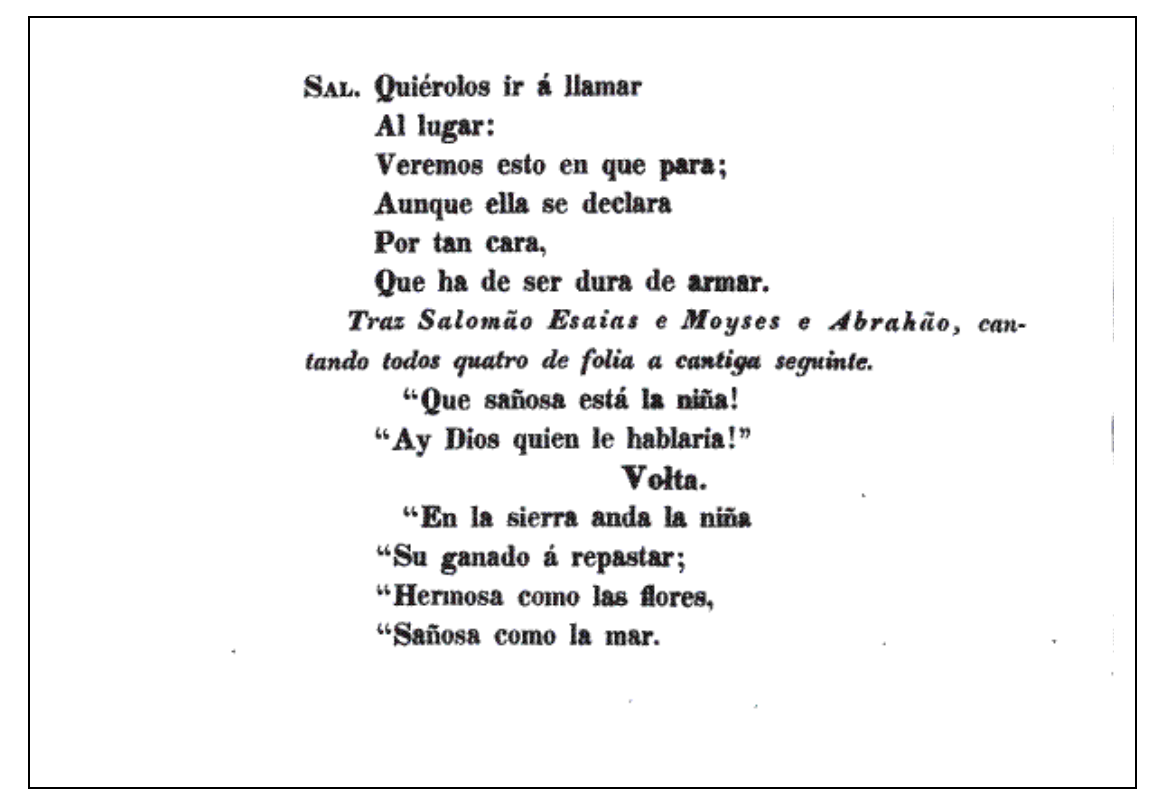

Fig 1.1: Trecho do Auto da Cassandra Sibila. In: Obras de Gil Vicente. Por Gil Vicente, José Victorino Barreto Feio, J. G. Monteiro. Fac-símile da Edição de Langhoff: Paris, 1834, p.46.

São muitas as fontes que indicam a presença da Folia na forma de danças e canções, assim como em diversas crônicas portuguesas dos XVI e XVII que descrevem grupos de camponeses animando os palácios com danças em casamentos e nascimentos, como na tragicomédia Templo d'Apolo (1526), também de Gil Vicente, na cena de casamento da "sacra e preclaríssima emperatriz" Dona Isabel: Cantadme por vida vuestra / en portuguesa folía / la causa de su alegría / y vere deso la muestra / y veréis la gloría mía ${ }^{10}$.

As obras de Vicente que fazem referência à Folia indicam sua presença na cultura popular tanto na forma de dança como de canção:

[...] E porque a graça e alegria

A madre da consolaçao

Den ao mundo ueste dia,

Nos vimos com devacao

A cantar-Шe hua folia.

E pois que ja descansamos

Assi em boa maneira,

Moças, assi como estamos,

Demos fim a esta feira,

\footnotetext{
${ }^{10}$ REMÉDIOS, 1912, p.176.
} 
Primeiro que nos partamos.

Alevantao-se todas, e ordenadas em folia emita rao a cantiga segttinte, com que se despediruo ${ }^{11}$.

Não tardou para que o tema começasse a evidenciar-se também em seus aspectos melódicos em diversos exemplos provenientes do cancioneiro português, como no vilançete, de acordo com a grafia da época, Nao tragais borzeguis pretos, de autor anônimo do século XVI ${ }^{12}$, escrito a três vozes a partir da linha de baixo da Folia, sobre o seguinte texto:

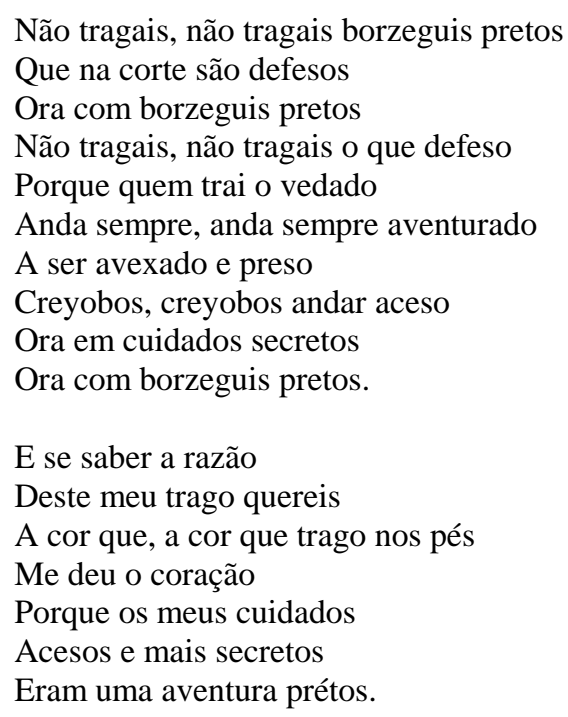

Recentemente, influências das culturas africana e oriental estão sendo apontadas no desenvolvimento da Folia ${ }^{13}$, ou pelo menos, algo de suas influências culturais lhe são atribuídas. Não é de se estranhar, pois escravos africanos eram trazidos para trabalhar nas plantações em Portugal desde o início do século XV. Os navios portugueses que exploravam a costa oeste traficando escravos travaram contato com a cultura moura, que

\footnotetext{
${ }^{11}$ Auto da Alma. VICENTE, apud FEIO, MONTEIRO, 1834, p.183.

${ }^{12}$ Manuscrito da Biblioteca da Escola Superior das Belas Artes de Paris (F-Pba, Ms. 56; CMBP, ff. 129v-130, n. $\left.{ }^{\circ} 127\right)$.

${ }^{13}$ GOMBOSI, apud FIORENTINO, p.6.
} 
ainda era forte na Península Ibérica, apesar da expulsão dos judeus em 1492 pelos monarcas espanhóis católicos Ferdinando e Isabella. Após 1500, a expansão colonial trouxe também à Europa algumas formas musicais africanas e ameríndias, como a chacona e a sarabanda $^{14}$

Os exemplos musicais que chegaram aos nossos dias, provenientes de arquivos preservados em palácios e igrejas datados dos finais do século $\mathrm{XV}$, já estão despidos de sua original dança barulhenta das ruas e dos vilarejos. Os insinuantes ritmos da música popular espanhola antiga, preservados desde o século $\mathrm{XVI}^{15}$, podem ilustrar, ainda que vagamente, como a Folia deveria contagiar os executantes e o público ${ }^{16}$.

A Folia também foi descrita no relato de Giovanni Battista Venturino, sobre a viagem do papa Pio V a Portugal em 1571, como uma dança portuguesa cujos dançarinos atavam címbalos e guizos aos pés, e que era celebrada em torno de um tambor com canções de versos alegres em loucos movimentos rodopiantes ${ }^{17}$, conforme dançada na cidade de Elvas $^{18}$ :

A Folia consistia de oito homens vestidos à moda portuguesa que, com címbalos e pandeiros tocavam juntos, sacudindo chocalhos amarrados aos pés, celebravam em volta de um tambor, cantando em seu idioma versos de alegria [...]. (NERY, 2005 , tradução nossa). ${ }^{19}$

Don Sebastián Covarrubias, famoso lexicógrafo de Toledo, também confirma a origem portuguesa da dança em seu Trésor de la langue castillane ou espagnole (1610):

[...] é uma certa dança portuguesa, muito barulhenta; pois resulta de muitos acessórios aos pés com chocalhos e outros instrumentos, carregadores fantasiados levam rapazes vestidos de mulher sobre seus ombros, que com os braços

\footnotetext{
${ }^{14}$ RESIDA, 2009.

${ }^{15}$ Spagnoletto, Canario, Balletto alle spagnuolo.

${ }^{16}$ Ibid.

17 “[...] cantadme por vida vuestra en portuguesa folia la causa de su alegría”. NERY, 2005.

${ }^{18}$ MORAIS, 2005.

${ }^{19}$ No original: "La follia, era di otto huomini vestiti alla Portughesi, che con cimbalo et cifilo accordati insieme, battendo con sonaglie à piedi, festeggiando intorno à un tamburo cantando in lor lingua versi d'allegrezza..."
} 
levantados vão fazendo giros, e às vezes dançam. E também tocam seus pandeiros: e é tão grande o ruído, e tão rápido, que parecem estar todos fora de seus juízos: e assim deram o nome à dança o nome folia da palavra toscana, Folle, que significa vão, louco, insano, que tem a cabeça vazia. (OROZCO, 1611, tradução nossa). ${ }^{20}$

Curt Sachs, comentando a descrição de Covarrubias, acrescenta que a mesma dança portuguesa estava relacionada com o carnaval $^{21}$, ao passo que Otto Gombosi a relaciona com outras danças européias associadas às celebrações rústicas para a colheita e centradas na figura do louco ${ }^{22}$. O musicólogo Manuel Morais ressalta que a Folia portuguesa, “[...] de baile-cantado renascentista, escrito sobre o modo maior, métrica de pulsação ternária e tempo vivo, passa, no período barroco, a uma dança estilizada, puramente instrumental, composta em tom menor, tocada com um andamento lento e cerimonioso" ${ }^{23}$.

\footnotetext{
${ }^{20}$ No original: "FOLIA, es una cierta dança Portuguesa, de mucho ruido; porque resulta de ir muchas figuras a pie con sonajas y otros instrumentos, llevan unos ganapanes disfraçados sobre sus ombros unos muchachos vestidos de donzellas, que con las mangas de punta van haziendo tornos, y a vezes bailan. $\mathrm{Y}$ tambien tañen sus sonajas: y es tan grande el ruido, y el son tan apressurado, que parecen estar los unos y los otros fuera de juizio: y assi le dieron a la dança el nombre de folia de la palabra Toscana, Folle, que vale vano, loco, sin seso, que tiene la cabeça vana."

${ }^{21}$ SACHS, apud FIORENTINO, 2009, p.6.

${ }^{22}$ GOMBOSI, apud FIORENTINO, 2009, p.6.

${ }^{23}$ MORAIS, op.cit., tradução nossa.
} 


\subsection{Espanha: diáspora da Folia pela península ibérica ${ }^{24}$}

Apesar da rica tradição literária portuguesa que descreve a prática da Folia na cultura popular, nas formas de danças e canções, os primeiros registros de exemplos musicais da Folia provêm da música espanhola renascentista. Nas primeiras décadas do XVI, o padrão musical da Folia ibérica consistia numa linha de baixo ostinato (ou ground $)^{25}$, sobre a qual se escreviam discantus e improvisavam-se variações, chamadas na época de diminuições.

As diminuições eram o protótipo da futura forma Tema e Variações, e surgiu de forma gradual no Renascimento a partir das improvisações que alteravam e embelezavam danças e canções populares. Por outro lado, a variação era um recurso inevitável utilizado pelos músicos que acompanhavam dançarinos, uma vez que essa música não tinha a função de fruição estética de concerto, com limites definidos e previamente concebidos, mas representava um suporte essencial para as coreografias. As matrizes temáticas ou rítmicas para danças populares, como a Folia, eram geralmente muito curtas para preencher uma coreografia completa, e o tema deveria ser repetido muitas vezes. Muitas técnicas de improvisação nasceram, portanto, dos métodos utilizados pelos músicos para adicionar variedade sem confundir os dançarinos ${ }^{26}$.

Alguns autores consideram que durante o século XVI a Folia não se caracterizava como tema musical, mas como uma seqüência harmônica que servia de pano de fundo para diversas canções polifônicas, além da própria Folia. O musicólogo norte-americano

\footnotetext{
${ }^{24}$ Para uma abordagem completa sobre o modelo harmônico da Folias no repertório instrumental e vocal da Espanha renascentista, cf. FIORENTINO, 2009.

${ }^{25}$ A linha de baixo da Folia era: A E A G C G A E / A E A G C G AE A.

${ }^{26}$ LITTLEWOOD, 2004, p.20.
} 


\author{
Richard Hudson sustenta a hipótese de que o Esquema $\mathrm{V}^{27}$ era genérico para diversas \\ canções e peças instrumentais renascentistas, e também que:
}

A primeira música para a folia anterior ocorreu na metade do desenvolvimento de um estilo musical que incorporou esquemas fixos de acordes como parte do processo de composição. A folia posterior surgiu somente depois que este estilo seguia seu percurso. [...] o esquema de acordes da folia anterior, por si próprio, não era uma característica específica da forma, pois a mesma progressão apareceu por mais de um século e meio também em outras formas. Já a folia posterior, por outro lado, não apareceu em nenhum outro formato proeminente. (HUDSON, 1973 , p.118, tradução nossa). ${ }^{28}$

Ainda dentro da teoria da Folia como um processo de composição baseada em uma

sequência fixa de acordes, o musicólogo Giuseppe Fiorentino, autor da pesquisa mais

extensiva sobre a presença da Folia no renascimento espanhol, aponta:

[...] a origem e difusão do esquema da folia nas fontes escritas coincidiu com a origem e difusão do estilo musical popularizante na Itália e Espanha. No caso de alguns temas musicais específicos, como a fórmula [Esquema V] de origem espanhola e La cara cosa, de origem italiana, a presença do esquema da folia em manuscritos e impressos foi o resultado da reelaboração direta do repertório popular. Em outros casos, o esquema da folia parece ser simplesmente a consequência do uso de processos de composição que imitavam o estilo popular, e que podem gerar a sequiência de acordes típica do esquema simplesmente a partir de uma melodia em modo menor. Ao longo dos séculos XV e XVI, a constante presença do esquema harmônico-melódico da folia em fontes musicais em todas as suas diferentes manifestações e variantes foi a conseqüência de um processo de composição e de um estilo musical, mediante os quais os músicos cultos imitavam ou simulavam imitar a tradição musical oral e popular. Junto ao estabelecimento de uma concepção acordal da música e junto às primeiras manifestações da linguagem tonal, o esquema da folia constitui uma das consequiências mais evidentes do lento e silencioso [sic] processo que naquela época marcou, de forma determinante, a evolução da linguagem musical ocidental: a interação entre a música de tradição oral e a música culta, ou melhor dizendo, entre a música da 'pequena tradição' e da 'pequena tradição' [...]. (FIORENTINO, 2009, p.624, tradução nossa) ${ }^{29}$.

\footnotetext{
${ }^{27}$ Os esquemas harmônicos de Richard Hudson são nomeados de acordo com o acorde que o diferencia dos demais, por exemplo: o Esquema IV contém o acorde de IV grau na sequência, enquanto o Esquema V é formado pelos acordes i $\underline{\mathrm{V}}$ i VII III etc. HUDSON, 1973, p.98-99.

${ }^{28}$ No original: "The first music for the earlier folia ocurred midway in the development of a musical style that incorporated fixed chordal schemes as a part of the process of composition. The later folia appeared only after this style had run its course. [...] the chordal scheme of the earlier folia, by itself, was not a special characteristic of the form, since the same progression appeared during the course of over a century and a half also in other forms. For the later folia, on the other hand, it appeared in no other prominent form."

${ }^{29}$ No original: “[...] el origen y la difusión del esquema de folía en las fuentes escritas coincidió con el origen y difusión del estilo musical popularizante en Italia y en España. En el caso de algunos temas musicales específicos, como la fórmula [...] de origen español y La cara cosa de origen italiano, la presencia del esquema de folía en manuscritos e impresos fue el resultado de la directa reelaboración del repertorio popular.
} 
Dentro da tradição ibérica quinhentista, Francisco Salinas, em seu De Mùsica Libri Septem $(1577)^{30}$, apresenta a primeira transcrição documentada da melodia Folia e reconfirma a origem lusitana do tema: "as canções populares que os portugueses chamam Folias, compostas segundo este metro [...] cuja melodia é [...]”31.

Desde então, a linha de baixo da Folia tornou-se recorrente em diversas peças polifônicas do início do século XVI, como base para diversas linhas melódicas contrastantes. Mesmo quando todos os elementos rítmicos e estruturais diferiam-se do tema, sua progressão de acordes era largamente utilizada na música antiga espanhola, aparecendo em várias coletâneas de peças polifônicas de importantes mestres vihuelistas, como na de Alonso Mudarra, publicada em 1546 - talvez a primeira versão escrita com variações do tema.

En otros casos, el esquema de folía parece ser simplemente la consecuencia del uso de procesos de composición que imitaban el estilo popular, y que pueden generar la secuencia de acordes típica de este esquema simplemente a partir de una melodía en modo menor. A lo largo de los siglos XV y XVI, la constante presencia del esquema armónico-melódico de folía en las fuentes musicales en todas sus diferentes manifestaciones y variantes fue la consecuencia de un proceso de composición y de un estilo musical, mediante los cuales los músicos cultos imitaban o pretendían imitar la tradición musical oral y popular. Junto a la afirmación de una concepción acordal de la música y junto a las primeras manifestaciones del lenguaje tonal, el esquema de folía constituye una de las consecuencias más evidentes del proceso lento y silencioso que en aquella época marcó de una forma determinante la evolución del lenguaje musical occidental: la iteracción entre la música de tradición oral y la música culta, o mejor dicho, entre la música de la "pequeña tradición" y de la "gran tradición" [...]."

${ }^{30}$ SALINAS, 1958.

${ }^{31}$ Tradução de MORAIS (2005). No original:[...] ita et ultima in eadem desinat, ut ostenditur in vulgaribus quas Lusitani Follias vocant, ad hoc metri [ypercatalecticis] genus et ad hunc canendi modum institutis, qualis est illa, cujus cantus usitatus est, [...] 


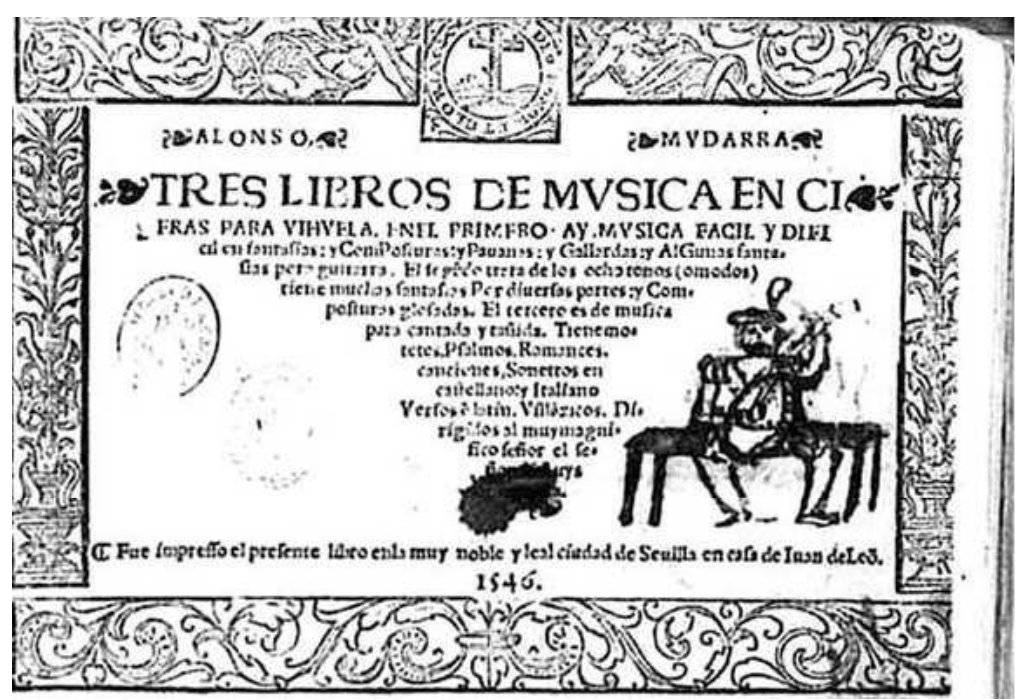

Fig.1.2: Frontispício dos Tres libros de música en cifra para vihuela, 1546.
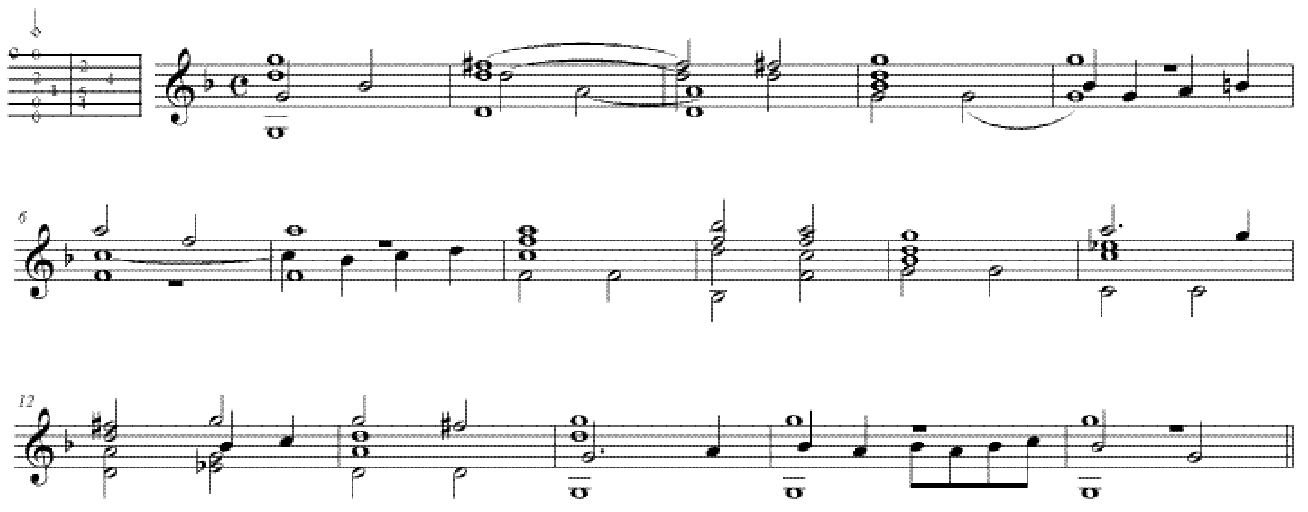

Fig.1.3: Alonso Mudarra: Libro I: Pavana I (Transcrição de E.Pujol). 


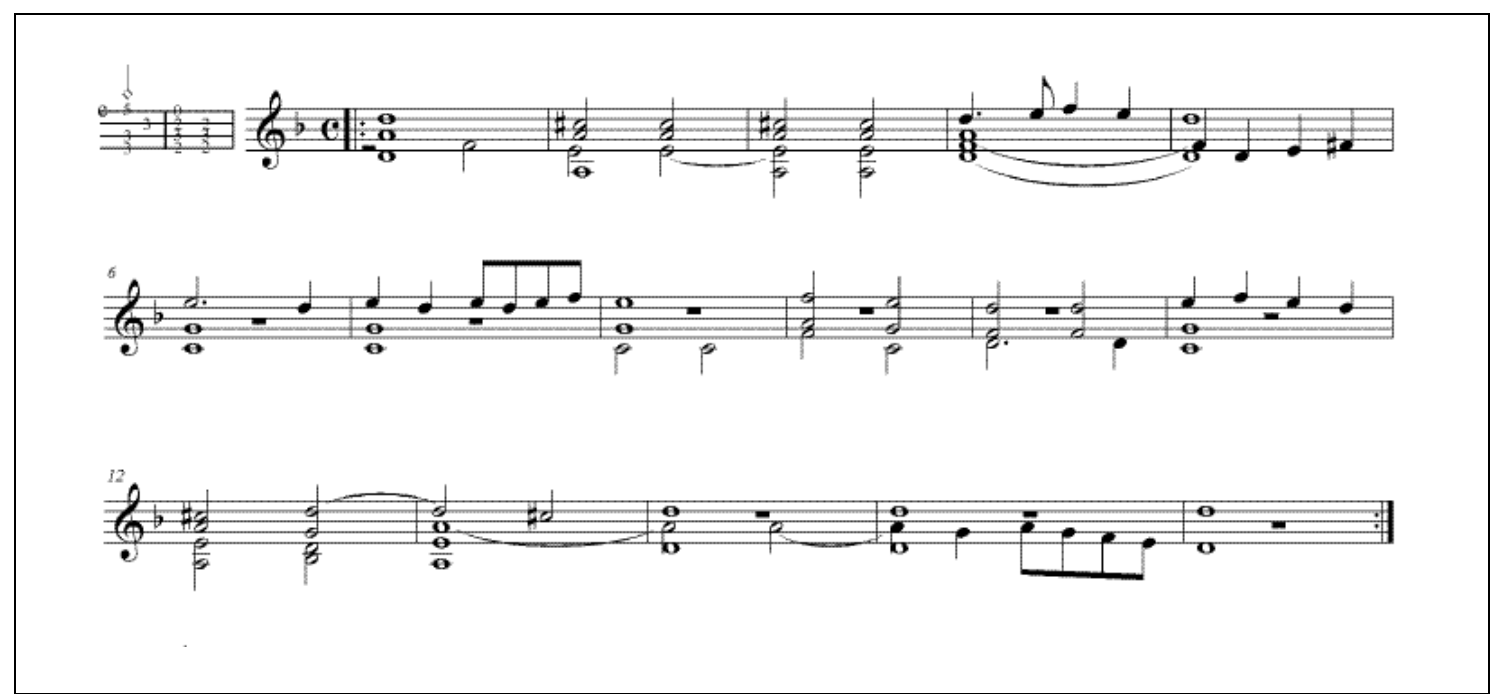

Fig.1.4: Alonso Mudarra: Libro I, N.22: Pavana III al temple nuevo (Transcrição de E.Pujol).

Em 1547 o vihuelista Enríquez de Valderrábano (c.1500-c.1557) publicou quatro variações sobre a Folia intitulada Diferencias sobre la Pavana no sétimo volume do Libro de música de vihuela intitulado Silva de Sirenas, conhecido apenas como Silva de Sirenas.

Considerada uma de suas obras mais ambiciosas, a transparente polifonia - um dos grandes atributos deste compositor - nas duas primeiras variações é contrastada com as rápidas escalas ornamentadas combinadas com acordes polifônicos, especialmente na última variação, exigindo grande habilidade do executante. 


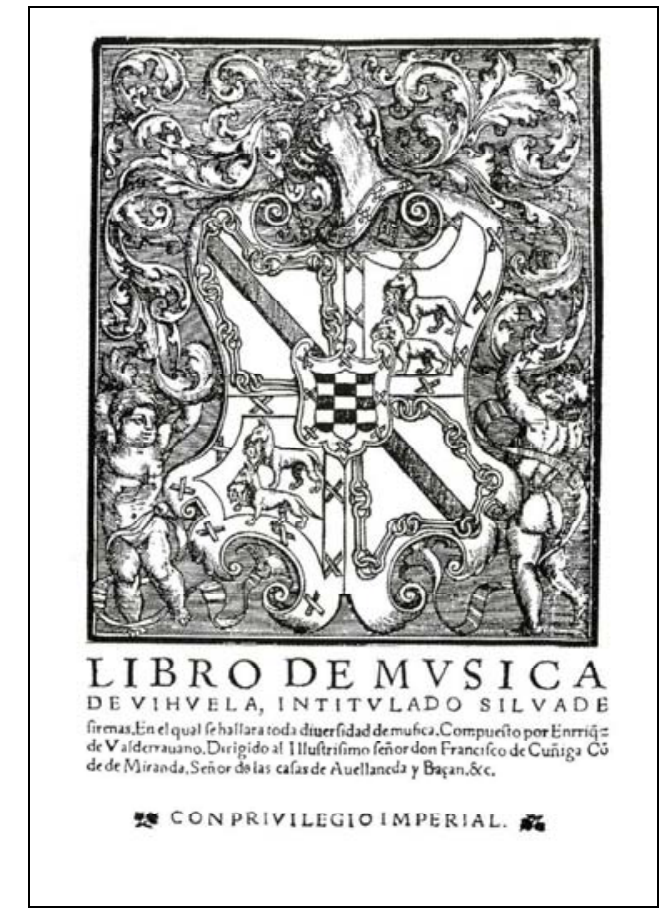

Fig.1.5: Frontispício do Silva de Sirenas, 1547.

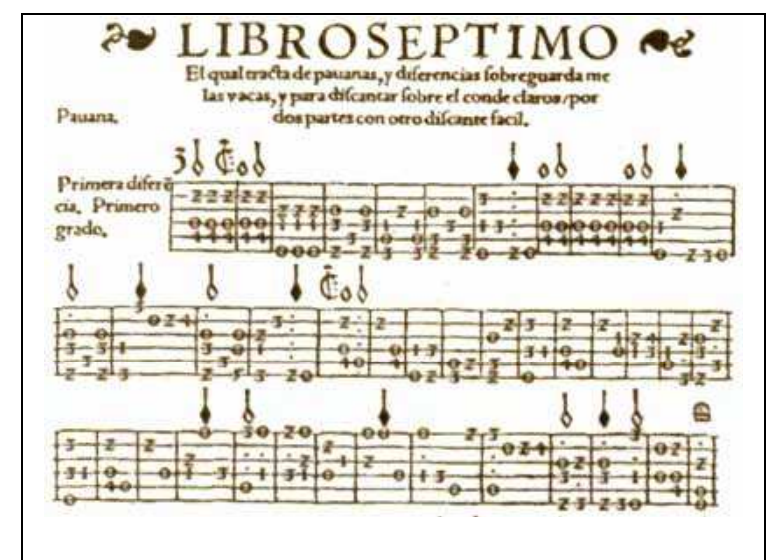

Fig.1.6: Diferencias sobre la Pavana, de E. Valderrabano.

Uma das mais famosas antologias de obras de música renascentista espanhola para vihuela foi compilada por Diego Pisador em $1552^{32}$. Publicada em Salamanca, a obra reúne em sete volumes os principais gêneros da época, resultado de quinze anos de pesquisa de

\footnotetext{
${ }^{32}$ ROA \& GÉRTRUDIX, 1552.
} 
Pisador $^{33}$, contendo 95 peças $^{34}$. Dentre estas, oito missas de Josquin, motetos de Gombert, Basurto, Morales, Mouton e Willaert, 22 canções espanholas e romances, madrigais e vilancicos. As obras originais de Pisador são 26 fantasias, variações sobre Conde Claros e Guárdame las Vacas, hinos contrapontísticos e salmos em falsobordão ${ }^{35}$. A segunda peça do primeiro livro é uma pavana baseada na Folia.

Em 1553 é publicado o famoso Trattado de Glosas para viola da gamba de Diego Ortiz, que contém inúmeros exemplos de variações sobre a linha de baixo da Folia (Recercadas Cuarta e Octava), executada pelo cravo em forma de ostinato, sobre a qual a viola executa diminuições virtuosísticas ${ }^{36}$.

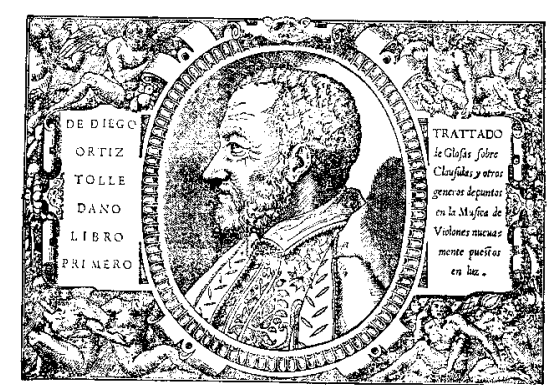

Fig.1.7: frontispício do Trattado de Glosas.

É muito provável que o ground Folia já tivesse adquirido a esta altura a reputação de uma forma musical ${ }^{37}$, extrapolando os limites de mera proposta temática para improvisações.

\footnotetext{
${ }^{33}$ Pisador afirma no livro que trabalhou nele durante seis anos, mas a carta de concessão real de Felipe II relata que o autor trabalhou por mais de quinze anos na elaboração.

${ }^{34}$ Se considerarmos cada parte das missas como uma peça isolada, são 186 peças no total.

$35 \mathrm{O}$ falsobordão, ou fabordão, era um dos antigos gêneros polifônicos que surgiram no final da Idade Média, caracterizado por uma harmonização em terças e sextas, cuja base fundamental é deslocada da voz mais grave, passando "falsamente" para a parte superior. O falsobordão favoreceu a independência das vozes na polifonia, pois se no organum a adição de uma nova voz ocorria com os intervalos de oitava e quinta da voz organal, no falsobordão as três vozes eram partes reais, partindo de notas diferentes, mesmo que em movimento direto.

${ }^{36}$ ORTIZ, 1553.

37 Cf. HUDSON, 1982, p.xv-xxvii, que sustenta que a Folia é uma das formas tradicionais barrocas, possuindo raízes comuns com chacona, passacaglia e sarabanda.
} 
Além disso, sua linha de baixo possui uma particularidade que pode explicar sua forte atratividade e sua promissora perenidade histórica: é possível reconhecer nela uma convergência entre diversos grounds em uso na tradição da música instrumental ibérica quinhentista, todos eles assemelhados ao baixo da Folia. Assim, esta última parece reunir uma confluência de diversos baixos conhecidos, atribuindo-lhe uma característica de síntese entre diversos gêneros instrumentais. Essa característica pode ter sido um fator de preferência de escolha tanto no plano artístico quanto pedagógico, já que a Folia era a linha de baixo mais simples de ser memorizada graças à sua estrutura palindrômica - ou seja, ela é a mesma lida ao inverso - e por utilizar apenas cinco sons.

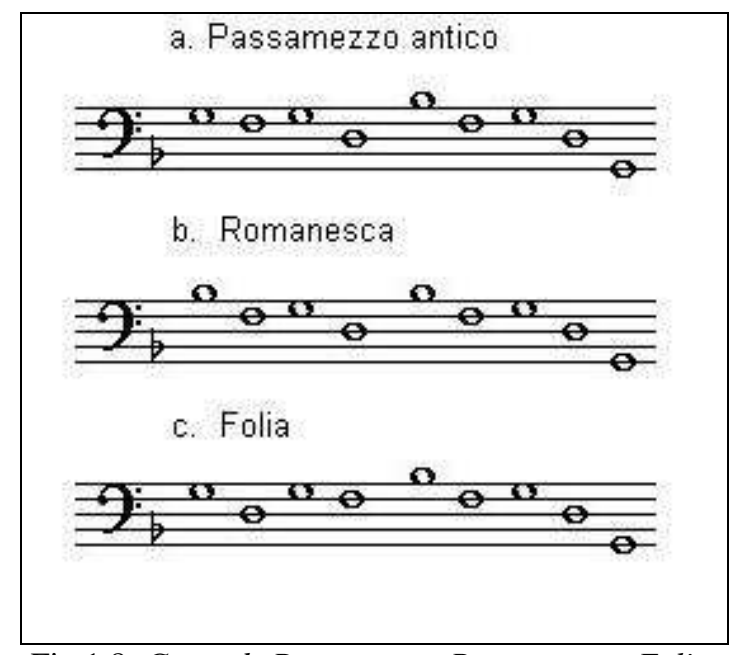

Fig.1.8: Grounds Passemezzo, Romanesca e Folia.

Os grounds acima descritos são provenientes de danças populares e surgiram na mesma época, em meados do século XVI. Estes eram apenas alguns dentre diversos grounds semelhantes, quase sempre elaborados em modo menor - geralmente o dórico - e com uma sequência de acordes que se repetia em variações ao longo da composição ${ }^{38}$.

\footnotetext{
${ }^{38}$ ANDERSON, 1992, p.78-81.
} 
A semelhança entre a Romanesca e a Folia é evidente, diferindo apenas na progressão inicial, em que a sequência A G A E é substituída pela A E A G. Nesses modelos, observamos que tanto a melodia quanto o baixo estão fundados sobre a sétima menor proveniente da escala pentatônica, o que confere às progressões uma sonoridade expressivamente ambígua entre o maior e o menor. Esse procedimento é tipicamente italiano, em que o baixo direciona-se para a relativa maior (III grau no $5^{\circ}$ compasso) enquanto a melodia conserva a estrutura menor ${ }^{39}$.

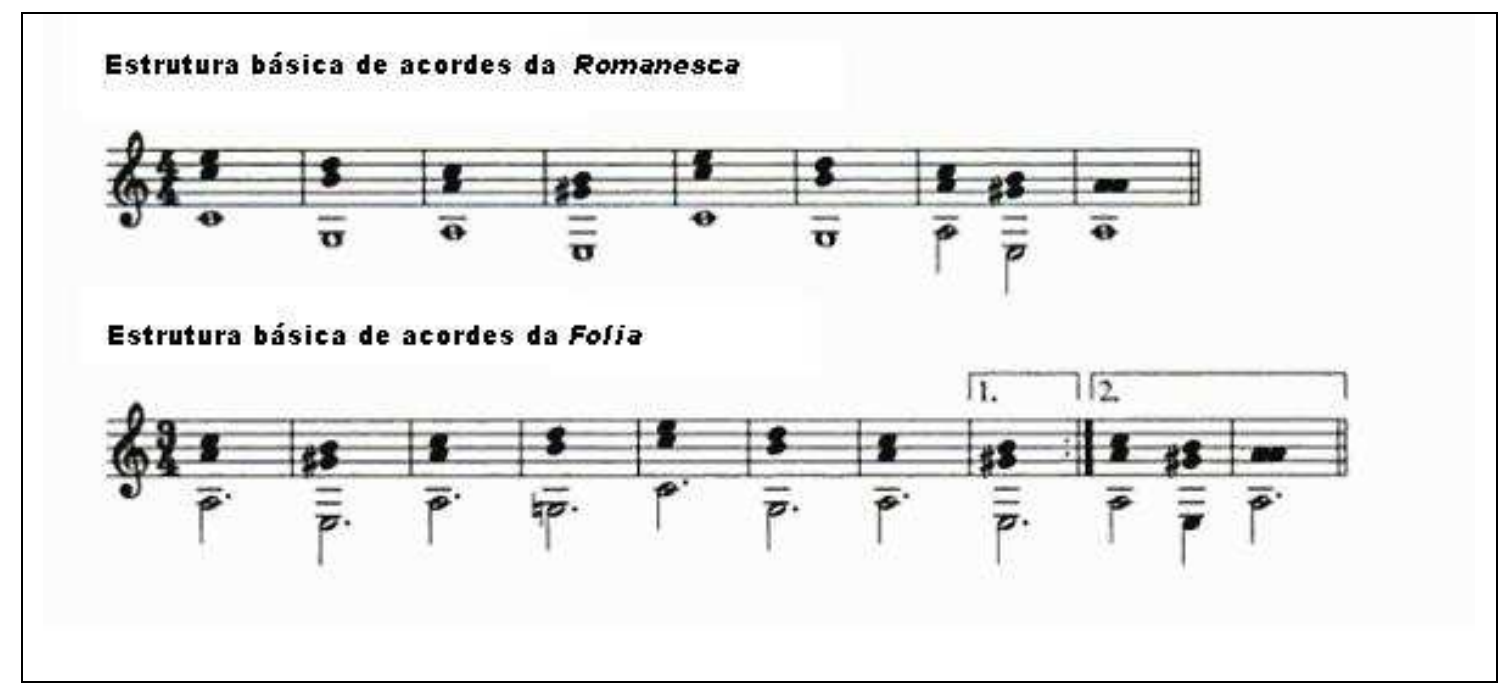

Fig.1.9: Estruturas básicas da Romanesca e da Folia.

Um dos aspectos mais essenciais e importantes no reconhecimento da estrutura melódica e, posteriormente, harmônica do tema Folia é seu formato palindrômico, desde as origens. Esse procedimento de escrita é proveniente da antiga técnica do moteto isorrítmico $^{40}$, já considerado um estilo musical arcaico na época de Guillaume Dufay (1397-1474) e largamente utilizado pelos compositores borgonhenses do final do século

\footnotetext{
${ }^{39}$ MERWE, 2004, p.97.

${ }^{40} \mathrm{O}$ moteto isorrítmico é uma antiga técnica de composição musical que remonta à prática dos séculos XIV e $\mathrm{XV}$. Trata-se da combinação determinada de uma seqüência de notas com uma estrutura rítmica. $\mathrm{O}$ compositor Philippe de Vitry (1291-1361), da Ars Nova, foi um dos primeiros a utilizar esta técnica. HOPPIN, 1978, p.363.
} 
XIV, em geral empregado em cerimônias públicas solenes, em contraste à sonoridade mais "moderna" do estilo da chanson ${ }^{41}$. O recurso palindrômico exerce um efeito de temporalidade ambígua ao tema Folias que, se por um lado, a projeta para as sonoridades já consideradas arcaicas na Renascença, por outro lado antecipa a estrutura harmônica do tonalismo emergente, em um espelhamento que também irá gerar um sentido de completude dentro do ambiente dialético (tese-antítese-síntese) do universo tonal ${ }^{42}$.

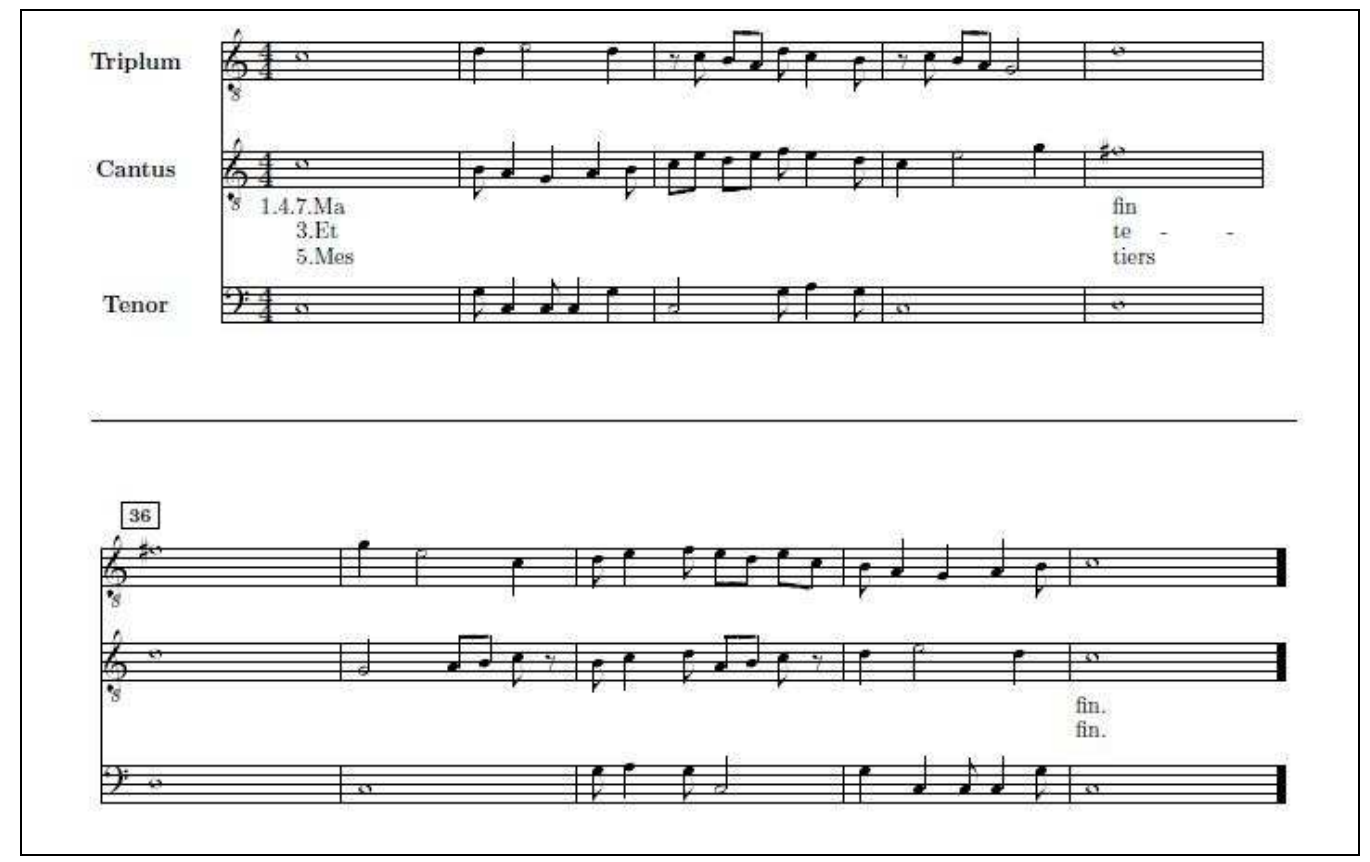

Fig.1.10: Exemplo de escrita palindrômica: compassos iniciais (1 a 5) e finais (36-40) do rondó a três vozes Ma fin est mon commencement de Guillaume Machaut (1300-1377).

A mesma estrutura harmônica baseada no Esquema V, ou Folias, ainda pode ser observada em outros tratados ibéricos, como no Cancionero del Palacio ${ }^{43}$ e em outros importantes livros de canções polifônicas e intabulações instrumentais, como a Pavana con su glosa - versão para órgão de Antonio de Cabezón da canção Para quién crié yo cabellos

\footnotetext{
${ }^{41}$ GROUT, PALISCA, 1997, p.175.

${ }^{42}$ A seqüência harmônica da Folias de Espanha pode ser considerada dialética pela própria função da estrutura de frases: Dm A Dm C (tese) / F C Dm A (antítese) / Dm A Dm C (tese) / F C Dm-A Dm (síntese).

${ }^{43}$ Cf. FIORENTINO, 2009: as canções Rodrigo Martínez, Adormoste Señor, De la vida deste mundo.
} 
- encontrada na antologia para teclado Libro de Cifra Nueva (1557), de Luis Venegas de Henestrosa; e a Folías con 20 diferencias (c. 1670?) de José Jiménez (1601-1678), que é uma das poucas variações para órgão encontradas na música espanhola do século XVII, e uma das mais notáveis, desde Cabezón.

A coleção espanhola de música para vihuela intitulada Ramillete de Flores provavelmente compilada em 1593 - inclui variações sobre a sequiência de acordes da Folia escritas por um obscuro compositor chamado Juan Andres de Mendoza (séc. XVI). Este parece ter sido um nobre aragonês, de quem se sabe que tocava bem a vihuela. Suas Diferencias de Folías seguem o estilo idiomático utilizado pelos autores vihuelistas do século XVI, porém contém certos traços melódicos e procedimentos imitativos que prefiguram as técnicas de variação utilizadas pelos guitarristas do século XVII, o que nos leva à concluir que Mendoza possa ter sido um dos últimos vihuelistas da história desse instrumento e que a Folia deve ter sido amplamente utilizada como tema para improvisações instrumentais na Espanha durante as últimas décadas do século $\mathrm{XVI}^{44}$.

Ao longo do século seguinte até a primeira metade do século XVIII, a Folia representava um símbolo do repertório vocal e instrumental ibérico. Os grandes músicos que escreveram para guitarra barroca, como Gaspar Sanz (1640-1710) e Santiago de Murcia (?-1732), incluíram-na em suas coletâneas para esse instrumento, como na obra Instrucción de Guitarra Española de Sanz, publicada em 1674, e na antologia manuscrita de Murcia do início do século XVIII, que hoje corresponde ao Codex Saldívar N.4.

\footnotetext{
${ }^{44}$ WILSON, 1990.
} 


\subsection{Possíveis transformações do ground Folia em acompanhamento}

Do surgimento da Folia na literatura portuguesa, descrita como uma selvagem dança de rua, até sua configuração tradicional como acompanhamento guitarrístico, podemos observar uma trajetória que teve como ponto de partida a tradição popular oral, que carece de registros mais precisos para uma correta delimitação.

Entretanto, se tomarmos a melodia da Folia como um referencial dado, provavelmente herdado da cultura popular ibérica, é possível visualizar o surgimento da progressão harmônica que se cristalizou como acompanhamento típico da dança. Essa transformação provavelmente ocorreu nas mãos de compositores de erudição e talvez idealizada para o ambiente cortesão, como veremos a seguir.

Um novo estilo de acompanhamento de acordes começou a se desenvolver na Espanha e Itália durante a segunda metade do século $\mathrm{XV}$, em seqüências de tríades distribuídas a quatro vozes, nota contra nota. Este modelo de escrita coral ao instrumento tornou-se um dos ideais renascentistas, expresso pela escrita de partes homogêneas. Apesar do estilo imitativo ser bastante utilizado, este também resultava em uma progressão de acordes, resultando nas primeiras fórmulas cadenciais, utilizadas sobretudo em danças e canções populares, e também no falsobordão.

Sucessões de acordes eram também utilizadas em outros gêneros renascentistas, como a missa, o moteto, as canções vocais, e em outros que incluíam uma linha melódica sobre a progressão harmônica - ou mesmo novos acordes - como no caso da intonazione e da toccata $^{45}$.

De acordo com as regras de construção de falsobordão de Guillelmus Monachus (final do século XV) em seu importante método De praeceptis artis musice et practice

\footnotetext{
${ }^{45}$ HUDSON, 1972, p.398.
} 
compendiosus libellus, escrito entre 1480 e 1490, é possível reconstruir a própria sequência de acordes tradicional da Folia. Nesse método, o autor recomenda a harmonização iniciando-se com uma progressão a duas vozes - soprano e tenor - em sextas, mas começando e terminando na oitava; em seguida adiciona-se a linha de baixo, formando uníssono ou oitava abaixo com o tenor no início e final, caminhando em alternância de intervalos de terças e quintas com o tenor, com uma quinta no penúltimo acorde; a voz contralto também alterna intervalos de terças e quintas com o tenor, utilizando uma quarta na penúltima nota. Richard Hudson aplica a fórmula de Monachus à melodia baseada na Folia transcrita por Salinas ${ }^{46}$, resultando na própria progressão harmônica (i V i VII III VII i V) utilizada largamente pelos guitarristas espanhóis e italianos ${ }^{47}$ :

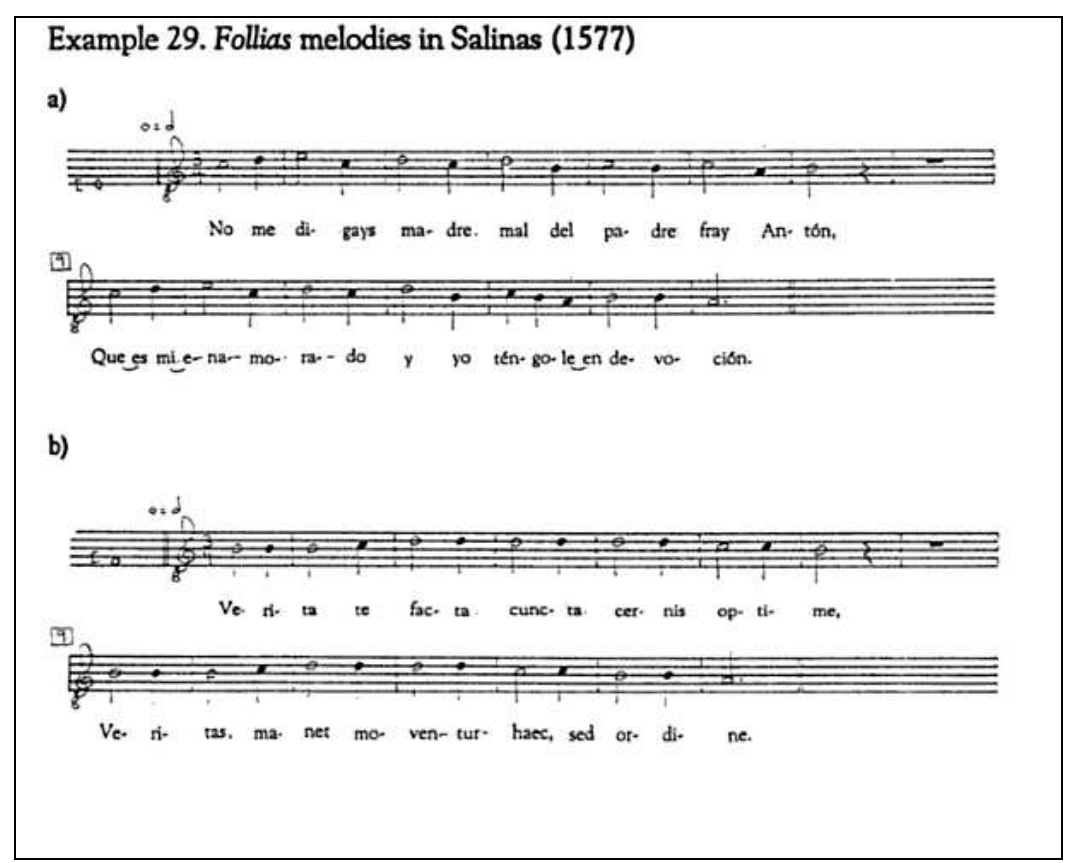

Fig.1.11: Transcrição da melodia publicada por Salinas em 1577.

\footnotetext{
${ }^{46}$ SALINAS, 1958.

${ }^{47}$ HUDSON, 1972, p.403.
} 


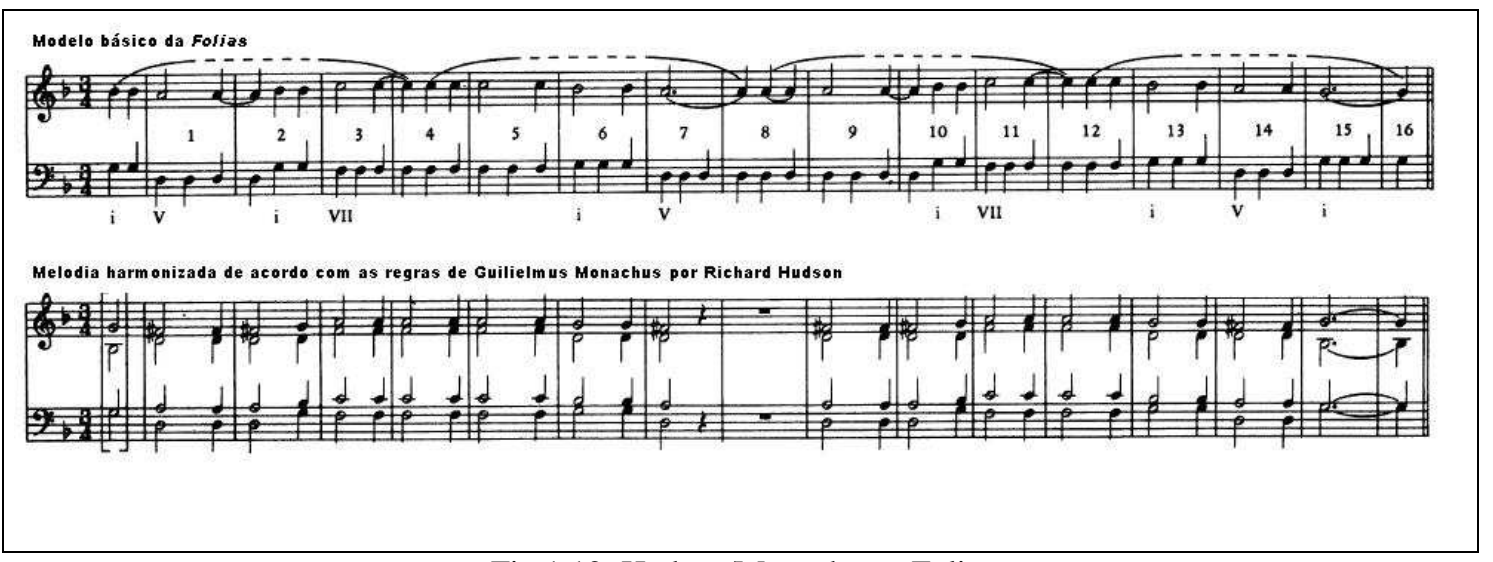

Fig.1.12: Hudson/Monachus = Folia.

É bastante provável que algum músico culto da sociedade européia - ou seja, um instrumentista de corte ou algum religioso, possivelmente espanhol - tenha chegado nessa progressão harmônica através de uma rigorosa harmonização em falsobordão da melodia de tradição oral baseando-se em algum método teórico respeitado, como o de Monachus.

Além da exata coincidência demonstrada através da harmonização da melodia de Salinas, a Folia e o falsobordão possuem outras similaridades. Ambas eram formas vocais estróficas, sendo que a primeira era executada com uma parte vocal solo - eventualmente em estilo coral, acompanhada por instrumentos harmônicos, enquanto que a última era realizada com todas as vozes a capella ${ }^{48}$. Além disso, a origem da história do estilo de acompanhamento em acordes ocorreu no final do século XV, durante o qual surgiram os mais famosos esquemas de acordes - Romanesca, Passemezzo, Folia, etc., de cadências, e também o falsobordão. Por volta dos anos 1570, houve um período de cristalização e revitalização do falsobordão, justamente quando Salinas apresenta a primeira versão conhecida da Folia. A primeira metade do século XVII foi a época do pleno

\footnotetext{
${ }^{48}$ HUDSON, op.cit., p.406.
} 
desenvolvimento do falsobordão e da consolidação da progressão harmônica da Folia no repertório italiano ${ }^{49}$.

As coincidências apontadas podem não esclarecer completamente o vínculo da produção musical renascentista popular com a cultura da elite da época, mas certamente representam um ponto de conexão bastante confiável para o devido rastreamento dessa interconexão entre a dança portuguesa e o acompanhamento tradicional.

\footnotetext{
${ }^{49}$ Ibid., p.410-411.
} 


\subsection{A Folia chega à Itália}

O tema Folia foi também cultuado na Itália no século XVI, podendo ser identificado em diversas variações instrumentais encontradas em obras de mestres italianos seiscentistas. Um dos mais antigos exemplos italianos é a peça La Gamba in Basso, e Soprano, coletada pelo mestre de capela da Catedral de Verona, Vincenzo Ruffo (15081587), e incluída na coletânea Capricci in Musica, de 1564.

Há muitos exemplos de variações sobre a Folia adaptados e desenvolvidos por importantes compositores italianos: o alaudista Alessandro Piccinini (1566-1638) em sua Intavolatura di Liuto (Bolonha, 1623), para teorba; o organista Bernardo Storace em seu Selva di Varie compositioni (Veneza, 1664), para teclado; dentre muitos outros exemplos ${ }^{50}$.

É interessante observar que a versão de Andrea Falconieri (1586-1656), intitulada Folia hecha para mi Señora Doña Tarolilla de Catallenos 1650, já possui todas as características sonoras do tema Folias de Espanha, com seu ethos solene, em ritmo de sarabanda, segundo tempo pontuado, antecipando de certa forma o surgimento da primeira versão do novo tema, que seria desenvolvido vinte anos mais tarde, na corte de Luís XIV, em Paris.

\footnotetext{
${ }^{50}$ NERY, op.cit..
} 


\section{ga Tiple ì g. Folizs echa part mi Scionora Dob̆a Tarolitla de Carallenos. (2) 14}

Fig.1.13: Folia hecha para mi Señora Doña Tarolilla de Catallenos, de Falconieri (original), 1650.

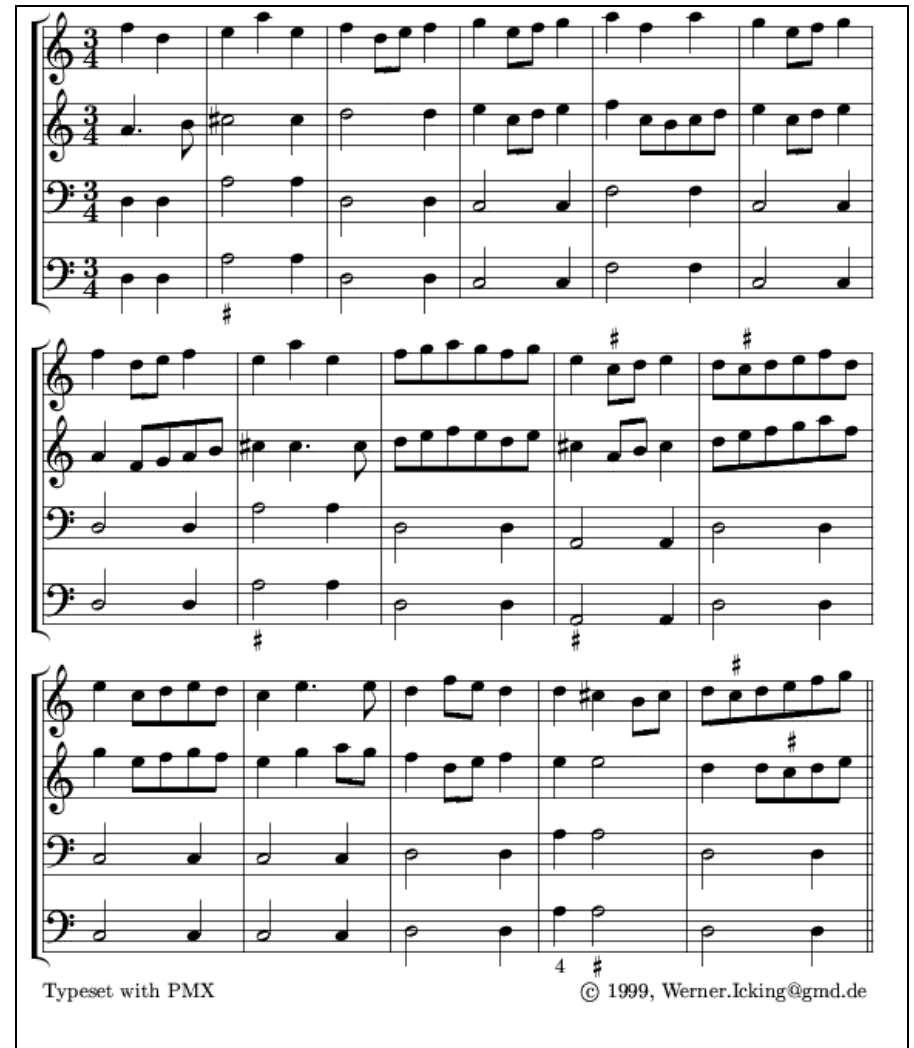

Fig.1.14: Falconieri, 1650, em notação moderna.

O tema aparece também em diversas publicações de música instrumental do norte italiano e de dança, e na estrutura harmônica de algumas frottole, tanto na sua forma 
original como em variantes, como a $L a G_{a m b a^{51}}$, a Pavaniglia ${ }^{52}$ e a famosa canzoneta

\title{
Cara Cosa:
}

\author{
"As Catarinas \\ Parecem rainhas \\ Então, vejamos \\ Que versos podemos compor: \\ Esse é modo que gostamos. \\ Os que já escrevi \\ Estão esquecidos, \\ Por isso tentaremos \\ Escrever alguns novos: \\ Esse é modo que gostamos.
}

Há um que gosto

Mais do que outro:

Mas a Fortuna

Quer o nosso sofrimento;

Esse é modo que gostamos.

Ela é uma coisa querida,

Doce como uma rosa.

Mas a dor que me espreme,

Não dá trégua.

Esse é modo que gostamos.

Ela é graciosa

De grande nobreza

Ardendo com amor

Como os vemos?

Esse é modo que gostamos.

Ó rosto santificado,

Tão cheio de virtude,

Eu não posso sequer dizer-lhe

quantas ele contém:

Esse é modo que gostamos.

Ela é livre

E muda seu humor,

A cada vez

Que brincamos,

Porque esse é modo que gostamos. ${ }^{53}$

\footnotetext{
${ }^{51}$ Título atribuído provavelmente por remissão à tradição de grandes gambistas contemporâneos e do passado que costumavam improvisar sobre a Folia.

${ }^{52}$ Uma dança instrumental bastante popular na Itália durante a primeira metade do século XVII.

53 "Les Caterines / La Cara Cosa". Música de autor anônimo do século XVI; texto de Joan Escrivà (Valencia 1450 - final do século XV, tradução nossa). No original: "Les Caterines / semblen regines; / donques veurem / quines coblas ne fem. / Tala la volem. / Las que he trobades / son obblidades; / per que, cercades, / d'altras ne farem. / Tale la volem. / Jo n'am una / mes que naguna, / e vol Fortuna / trebal passem. / Tale la volem. /
} 
É possível perceber, nesta transcrição do texto, que o acompanhamento de Folia se adaptou à uma canção de temática amorosa com tendência platônica e certos traços do pathos melancólico que a música assumiria no século XVII. Em outra canção do início do mesmo século, identificamos outros elementos que despontarão no afeto melancólico que a Folia assumirá na sua forma de Folias de Espanha, especialmente aqueles apontados nas discussões sobre a loucura e furor - que serão detalhados adiante - em humanistas como Erasmo de Roterdã e Emmanuele Tesauro: "Eu sou a loucura / Que promove / O prazer e a doçura / E a alegria ao mundo / Todos usam meu nome / Pouco ou muito / Mas ninguém / Se considera um louco." ${ }^{54}$

Diversas canções italianas foram baseadas nessa mesma estrutura harmônica, assim como obras polifônicas e intabulações instrumentais. Encontramos exemplos baseados na Folia em diversos métodos instrumentais espanhóis e italianos ${ }^{55}$. Ou seja, ela era um acompanhamento básico originário da cultura popular ibérica seicentista, assimilada pela tradição vihuelística e guitarrística que seria posteriormente exportada para as cortes de maior prestígio da Europa.

As diversas peças que continham apenas uma única apresentação do tema Folia foram provavelmente elaboradas para acompanhamento de danças ou canções do universo social da música popular. Mesmo em algumas composições com variações do tema é

Es cara cossa, / gentil come rosa; / mes no reposa / lo mal que prem. / Tale la volem. / Es molt cortesa, / de gran noblesa; / de amor ensesa / com la veurem?

/ Tale la volem. / Cara de sancta, / de virtut tanta; / no puch dir quanta ne la compren. / Tale la volem. / Es desembolta, / muda la volta / mes de revolta hi jugarem. / Tale la volem"

${ }^{54}$ Passacalle La Folie (1614) de Henri le Bailly (? -1637, tradução nossa). No original: "Yo soy la locura / la que sola infundo / placer y dulzura / y contento al mundo / Sirven a mi nombre / todos mucho o poco, / y no, no hay hombre / que plense ser loco."

Apesar do título, esta não é propriamente a Folia, mas uma passacaglia que fazia parte de um ballet composto por Le Bailly para a rainha Ana de Áustria (1601-1666).

${ }^{55}$ Libro Primo de tablaturas para guitarra (Florença 1640) de Angelo Michele Bartolotti de Bologna (16151650?); Intabolatura de lauto (1546) para viola da gamba de Bianchini (século XVI); Método mui facilissimo (1626) de Luis de Briceño (século XVII). 
possível detectar algo da qualidade simples e rude da música popular ${ }^{56}$. Outras obras já apresentam elaborações de qualidade artística mais refinada, com passagens melódicas virtuosísticas e elevada complexidade rítmica ${ }^{57}$.

Percebemos que, neste momento da história, a Folia está oscilando entre as culturas

popular e dominante:

\begin{abstract}
Até mesmo o maior dos compositores do século XVII da Península [Ibérica], o catalão Joan Cabanilles (1644-1712), não sentiu que seria indigno de seu talento cultivar o gênero [Folia], ao lado de seus majestosos tientos contrapontísticos. A maioria desses compositores ficou conhecida em sua vida não apenas por seu virtuosismo instrumental, mas também por suas habilidades em aplicá-lo às longas improvisações de temas conhecidos. Em suas variações sobre a Folia, não há como evitar a sensação de que elas foram publicadas como meros exemplos de seus talentos improvisatórios, e que os próprios compositores poderiam modificar o texto escrito a cada vez que os executassem, num modo muito mais significativo do que eles ousariam fazer ao executarem um gênero estrito de composição musical. Por outro lado, o estilo de composição dessas peças certamente não é "popular", no sentido próprio do termo, mas uma obra tanto de um habilidoso virtuose como de um compositor academicamente treinado, a força rítmica da música sugere que ela é ainda um repertório pensado para uma elite dominante, mas no entanto mais próxima de suas antigas raízes populares do que poderia ser no caso de gêneros instrumentais mais sofisticados, como no Tiento ou na Fantasia. É também fascinante observar o fato de que os gêneros musicais ibéricos e latino-americanos deste período contêm um forte componente transcultural, como o Cumbés afro-brasileiro de diversas coleções portuguesas para guitarra do início do século XVIII, muitas vezes com sequências de acordes muito similares à Folia, mesmo quando os combinavam com ritmos e modelos melódicos não-europeus. É o caso da Cachua andina extraída da coleção de canções e danças ameríndias, congregadas pelo bispo peruano Baltazar Martinez Companon na metade do século dezoito, que corresponde a um verdadeiro reprocessamento do modelo original ibérico nas mãos de músicos ameríndios. (NERY, 2005, tradução nossa). ${ }^{58}$
\end{abstract}

\footnotetext{
${ }^{56}$ Cf. as obras Folias sopra l'0 com parti variate e Fulias com parti variate (c.1640), para guitarra, de Foscarini; Tonos de Palacio Folias (1707), para teclado, de autor anônimo espanhol.

${ }^{57}$ Cf. a obra Folia, c. 1604 para teorba (Kapsberger).

${ }^{58}$ No original: "Even the greatest of all Peninsular keyboard composers of the late seventeenth century, the Catalan Joan Cabanilles (1644-1712), did not feel that it would be unworthy of his talent to cultivate the genre, side by side with his majestic contrapuntal tientos. Many of these composers were known in their lifetime not only for their instrumental virtuosity but also for their ability to apply it to lengthy improvisations on well-known musical themes. In their settings of variations on the Folia one cannot not avoid the feeling that these are published as mere examples of their improvisatory talent, and that the composers themselves would most likely change a great deal of the written musical text every time they performed it, in a much more significant way than they would dare to do when performing a stricter genre of musical composition. On the other hand, although the style of composition in these pieces is certainly not "popular", in the proper sense of the word, but rather the work of a skilled virtuoso and an academically trained composer, the rhythmic strength of the music suggests that this is still a repertoire intended for an upper-class elite but nevertheless much closer to its remote popular roots than would be the case of the more sophisticated instrumental genres, such as the Tiento or the Fantasia. It is also fascinating to observe the fact that Iberian and Latin-American musical genres of this period that contain a strong cross-cultural component, like the Afro-Brazilian Cumbés
} 


\subsection{Conexões com o surgimento da guitarra barroca}

O surgimento de um novo instrumento também parece estar diretamente associado ao surgimento da Folias de Espanha em sua forma definitiva: a guitarra de 5 ordens ${ }^{59}$.

Durante a Idade Média, existiram guitarras de três, quatro e cinco ordens, sendo que durante o século $\mathrm{XV}$, a de quatro ordens se sobressaiu em termos de popularidade. Uma versão aperfeiçoada da guitarra renascentista de quatro ordens surgiu no século XVII, com a adição de uma quinta corda, talvez introduzida por Vicente Espinel (1550-1624), que abalou consideravelmente a soberania do alaúde como instrumento da classe nobre na Europa e fazendo dela um instrumento indispensável em qualquer corte. O número de compositores, executantes e construtores aumentou consideravelmente.

A primeira evidência da guitarra de cinco ordens provém de uma gravura italiana do século XV. O novo instrumento parece ter o mesmo tamanho dos violões atuais, diferindo apenas no tamanho maior da caixa de ressonância. Sua excelente construção chama a atenção para o artesanato sofisticado pelo qual os construtores italianos eram conhecidos.

A guitarra de cinco ordens foi, portanto, o resultado direto do desenvolvimento daquela de quatro ordens. A afinação da guitarra de cinco ordens era A D G B E. Sendo idêntica à afinação daquela de quatro ordens, a quinta corda foi apenas adicional. Ela emergiu da Itália para uma crescente popularidade no século XVI em toda Europa. O novo instrumento passou rapidamente a gozar de considerável importância na vida musical italiana da época. O grande número de compositores e guitarristas vivendo na Itália, e os

of the several Portugal guitar collections of the early eighteenth century, often present chordal sequences that are very similar to those of the Folia, even when they combine them with non-European rhythmic and melodic patterns. That is the case of an Andean Cachua extracted from the collection of Amerindian songs and dances assembled in the mid-eighteenth century by the Peruvian Bishop Baltazar Martinez Companon, which corresponds to a true reprocessing of the Iberian original model at the hands of Amerindian musicians." ${ }^{59}$ Cordas duplas. 
vários instrumentos remanescentes atestam que este país foi o maior centro guitarrístico no século XVII.

$\mathrm{O}$ fator mais importante que conduziu à popularidade da guitarra e ao enriquecimento de sua literatura foi a introdução do estilo dedilhado, proveniente da Espanha. O estilo de toque dedilhado substituiu o rasgueado que dominava a prática italiana no século XVI. A técnica dedilhada, por sua vez, era derivada da escola da vihuela adaptada à guitarra pelos espanhóis ${ }^{60}$. Por essa razão, a guitarra passou a ser chamada na Itália de Chitarra Spagñuola. Assim que os italianos adotaram o termo "guitarra espanhola", houve uma gradual consolidação que a tornou padrão em vários países no século XVII, perdurando até hoje ${ }^{61}$.

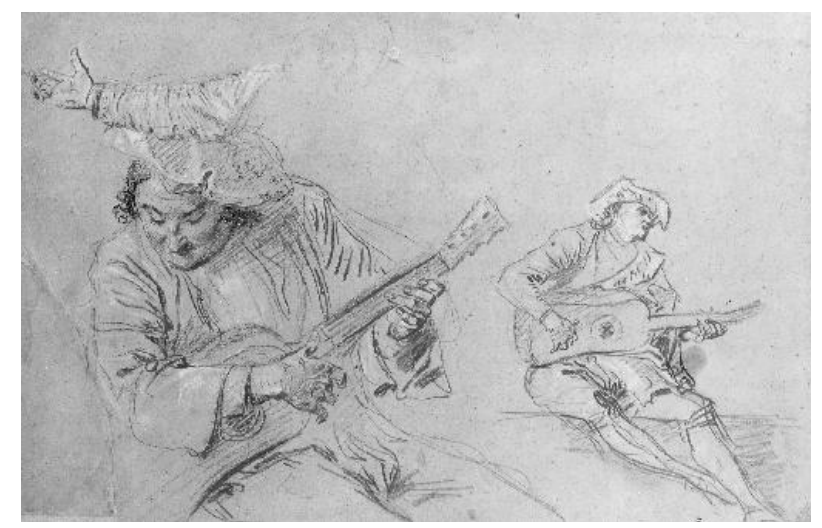

Fig.1.15: Dois rascunhos de um guitarrista por Antoine Watteau (1684-1721), início do século XVIII (British Museum, Londres), em que observamos duas técnicas de execução da guitarra: perto do cavalete (para o estilo punteado) e acima da roseta (para o rasgueado)

Os grandes mestres da guitarra barroca de cinco ordens que publicaram métodos dedicados ao ensino do instrumento, como Gaspar Sanz e Francesco Corbetta (1615-1681),

\footnotetext{
${ }^{60}$ Os estilos dedilhado e rasgueado coexistiram na Itália do século XVII. O dedilhado era escrito em tablatura e os acordes rasgueados eram indicados através de uma notação especialmente desenvolvida pelos compositores dos séculos XVI e XVII, feita pela conversão de letras maiúsculas por acordes prédeterminados, método hoje conhecido como Cifras.

${ }^{61}$ Exceto no Brasil, único país do mundo que adota o termo "violão".
} 
incluíam instruções detalhadas sobre improvisação e execução em tablatura e notação modernas, em ambos os métodos: dedilhado e rasgueado.

A maioria dos métodos para esse novo instrumento incluía exemplos de acompanhamentos rasgueados baseados em canções conhecidas, e como já vimos, a Folia já era um tema favorito. Desse modo, não apenas a guitarra "espanhola" foi importada da Itália para os demais países, como a própria Folia, que passou a ser designada com o mesmo sufixo: "de Espanha".

Várias peças escritas entre o final do século XVII e início do XVIII alternavam entre a Folia e a Folias de Espanha, com distinções bem definidas entre os dois padrões. Porém, as obras que continham passagens em estilo rasgueado eram precariamente notadas, o que dificulta uma comparação mais detalhada no aspecto rítmico ${ }^{62}$.

Richard Hudson propôs uma teoria que pode explicar a transição gradual entre esta e a Folias de Espanha, envolvendo as seguintes etapas ${ }^{63}$ :

a) Redução do andamento: devido às complexas variações melódicas elaboradas sobre o acompanhamento de acordes, especialmente em instrumentos mais graves, como a teorba $^{64}$, que requeriam um tempo muito mais vagaroso para seu tipo de ressonância. Além disso, à medida que foram surgindo novas variações para guitarra em estilo dedilhado, por volta de 1640, o aumento da quantidade de notas exigia uma gradual redução do andamento. Não tardou para que aparecessem marcações individuais para variações específicas, como na nona variação da obra Folías para Señora Doña Tarolilla de Carallenos, de Falconieri, que ostenta a indicação muy despacio;

\footnotetext{
${ }^{62}$ HUDSON, 1982, p.xxv.

${ }^{63}$ Ibid., p.xxv-xxvii.

${ }^{64}$ Cf. as obras: Folia (1604) de Kapsberger; Partite variate sopra la Folia (1623) de Piccinini, ambas escritas para teorba .
} 
b) Ênfase do segundo tempo das anacruses no compasso de abertura: um procedimento identificado na maioria das obras em estilo francês. Instrumentistas de outras nacionalidades, como Luis de Briçeño, Antonio Carbonchi e Giovanni P. Foscarini estavam familiarizados com a métrica das danças de corte francesas, que tinha como uma de suas características pontuar o segundo tempo dos compassos ternários, do mesmo modo que o faziam com danças como a passacaglia e a chacona. Duas versões de 1671 da Folias escritas por Corbetta ${ }^{65}$ já contêm notações precisas de notas pontuadas desde a apresentação do tema, além da redução de andamento devido à abundante ornamentação, também característica do estilo francês;

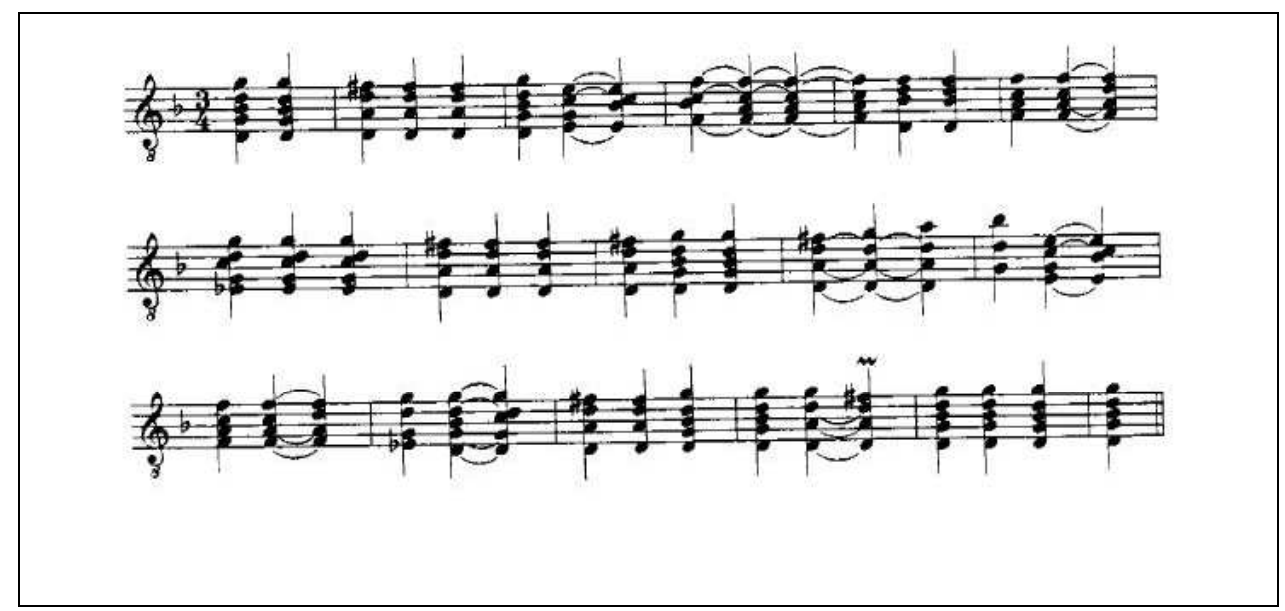

Fig.1.16: Corbetta: Folias, 1671a.

c) Início de figuração de uma nova variação antes do término da anterior: a lembrança da anacruse inicial pode ser ainda mais obscurecida ao iniciar uma nova variação antes da duração completa do compasso, levando ao ouvinte uma sensação temporariamente irregular da métrica, pois ao ouvir o segundo tempo pontuado, ele

\footnotetext{
${ }^{65}$ Cf. figura 1.17 .
} 
assimila a informação de que o acorde inicial era o tempo forte $e^{66}$. Nas variações de Kapsberger de 1604, o tema inicia-se como se estivesse incompleto, porém o compositor adicionou uma pausa iniciando cada variação com a intenção de delimitar a duração completa. Numa execução contínua, é evidente que as pausas devem ser emendadas na variação seguinte. Diversas obras a partir de 1640 utilizam desse efeito ilusório-auditivo. Corbetta, em suas variações de 1671, obscureceu ainda mais a apreensão da anacruse com a adição de uma apojatura, seguindo nos compassos seguintes com notas isoladas, resultando num grande contraste em relação aos acordes rasgueados, o que dá uma sensação de grande instabilidade rítmica.

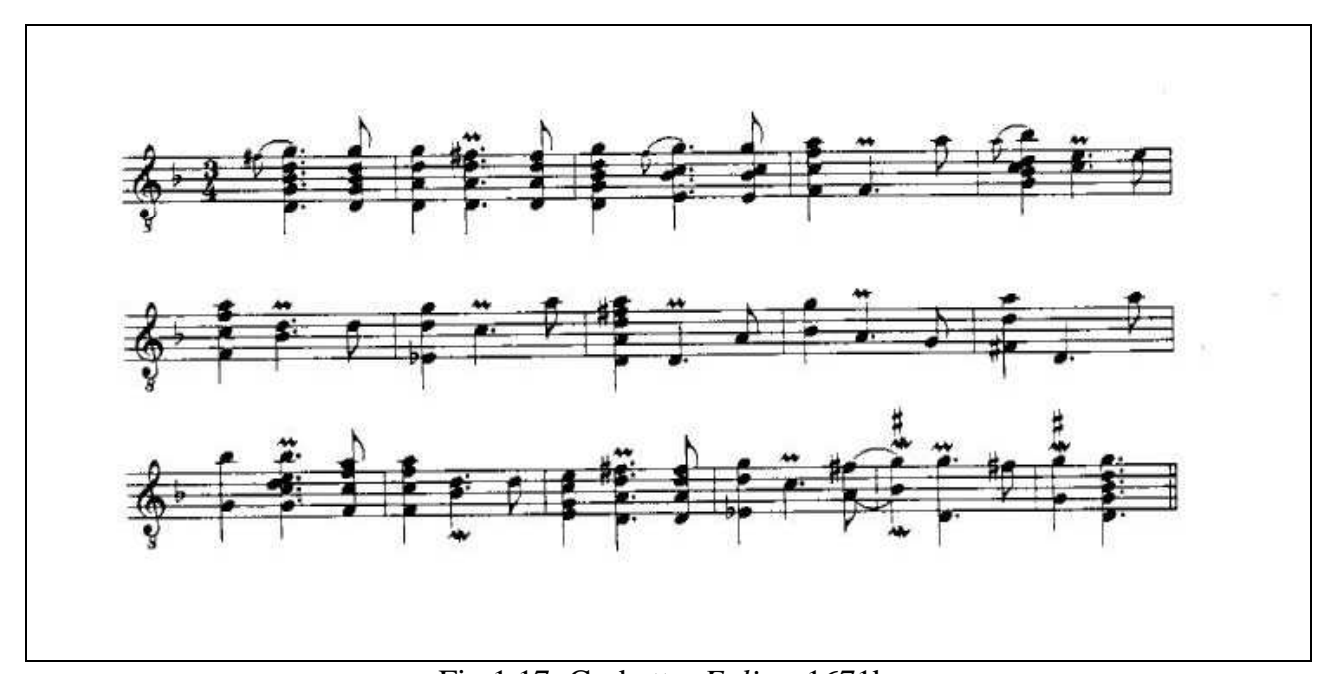

Fig.1.17: Corbetta: Folias, 1671b.

d) Mal-entendimento da estrutura rítmica anacrúsica por quem não lia partitura: um exemplo de notação alternativa ocorre na breve peça de 32 compassos intitulada Folies, localizada no Livre de guitarre publicado em 1671, em Paris, por Antoine Carré ${ }^{67}$. Trata-se de um raro exemplo de Folia publicada na França. As barras de compasso foram trocadas ${ }^{66}$ Cf. a obra Ciaconna BWV 1004 (1720) de J. S. Bach.

${ }^{67}$ CARRÉ, 1977. 
de lugar para um tempo de semínima adiante, fazendo com que toda a peça contenha o acento forte no terceiro tempo de cada compasso. Entretanto, na escrita da repetição da segunda parte, com a mudança de textura para o estilo dedilhado, os acentos começam a coincidir com as barras, o que reflete a influência da escrita na própria estrutura do tema.

Em suma, o deslocamento do acento pode ter percorrido este caminho:

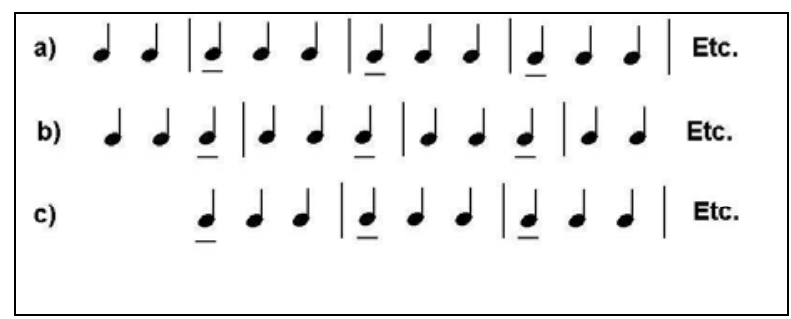

Fig.1.18: possível transição rítmica da Folia para Folias de Espanha

Para consolidar-se finalmente com a rítmica em estilo francês:

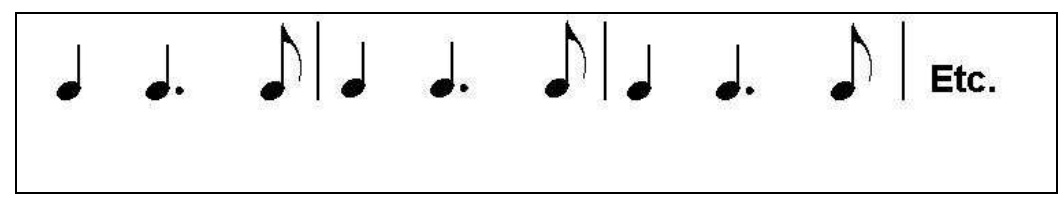

Fig.1.19: rítmica da Folias de Espanha.

Não é de estranhar que a estrutura da Folia, com todas as transformações ocorridas devido às características instrumentais e estilísticas, não soasse ao ouvido dos franceses da mesma forma que os italianos conheciam e escreviam há mais de cinqüenta anos. 


\begin{tabular}{|c|c|c|}
\hline & FOLIA & FOLIAS DE ESPANHA \\
\hline Período & - 1577-1674, com casos isolados até 1774 & - $1672-1750$ \\
\hline Local & - Portugal e Espanha & - Predominantemente na França e Inglaterra \\
\hline Estrutura & $\begin{array}{l}\text { - Quatro frases de } 4 \text { compassos } \\
\text { - Eventualmente com repetição da segunda } \\
\text { parte } \\
\text { - Frequentemente possui dois ritornelli } \\
\text { - O primeiro acento recai sobre o acorde de } \\
\text { Dominante }\end{array}$ & $\begin{array}{l}\text { - Duas sessões de } 8 \text { compassos } \\
\text { - Sem repetição interna além do paralelismo } \\
\text { harmônico das duas partes } \\
\text { - Não possui ritornello } \\
\text { - O primeiro acento recai sobre o acorde de } \\
\text { Tônica, modificando a estrutura por completo }\end{array}$ \\
\hline Ritmo & $\begin{array}{l}\text { - Geralmente possui dois tempos de } \\
\text { anacruse } \\
\text { - Andamento rápido e vivo } \\
\text { - Acentos nos segundos tempos } \\
\text { frequentemente gerados por mudanças de } \\
\text { acordes (ordinariamente em qualquer } \\
\text { compasso, exceto no } 4,8,12 \text { ou 16) } \\
\text { - Os acordes podem apresentar durações } \\
\text { diferentes em relação à estrutura padrão (ver } \\
\text { Fig.XX) } \\
\text { - Alternância entre duas métricas diferentes; } \\
\text { ritmos cruzados entre a melodia e o } \\
\text { acompanhamento de acordes }\end{array}$ & $\begin{array}{l}\text { - Geralmente não possui nenhuma anacruse } \\
\text { - Andamento lento e nobre } \\
\text { - Acentos gerados pelo ponto de aumento dos } \\
\text { segundos tempos, especialmente nos compassos } \\
\text { ímpares. } \\
\text { - Cada acorde ocupa um compasso completo } \\
\text { (exceto o 15) } \\
\text { - Ênfase estável e insistente sobre o tempo ternário } \\
\end{array}$ \\
\hline Harmonia & $\begin{array}{l}\text { - Pode utilizar uma tônica maior ou menor } \\
\text { ou até mesmo misturá-las na apresentação } \\
\text { do tema } \\
\text { - Preferencialmente em Sol menor, mas } \\
\text { pode ocorrer em qualquer outra tonalidade } \\
\text { maior ou menor } \\
\text { - Não inclui o III na estrutura padrão, mas } \\
\text { pode ocasionalmente ser adicionado } \\
\text { - Frequentemente incorpora novos acordes } \\
\text { (IV, II ou III) à estrutura-padrão, como } \\
\text { principal método de variação } \\
\text { - A estrutura padrão de acordes também era } \\
\text { utilizada em outras formas durante esse } \\
\text { período }\end{array}$ & $\begin{array}{l}\text { - Utiliza tônica no modo menor } \\
\text { - Quase sempre em Ré menor } \\
\text { - Quase sempre inclui o III, em ambas as partes } \\
\text { - Raramente inclui novos acordes } \\
\text { - A estrutura padrão de acordes era exclusiva } \\
\text { desta forma nesta época da história }\end{array}$ \\
\hline Melodia & $\begin{array}{l}\text { - A estrutura padrão melódica é baseada } \\
\text { nos graus 3-2-3-4-(5)-4-3-2; o grau } 5 \\
\text { aparece quando o III está incluído } \\
\text { - Ampla gama de variantes, tanto nas } \\
\text { alturas quanto nas durações, em relação à } \\
\text { estrutura padrão melódica } \\
\text { - Podem ocorrer repetições de graus, mas } \\
\text { não como característica fixa }\end{array}$ & $\begin{array}{l}\text { - A estrutura-padrão melódica desce uma terça em } \\
\text { relação à Folia } \\
\text { - Padrão melódico quase fixo na França e na } \\
\text { Inglaterra; em temas com variações a melodia é o } \\
\text { elemento principal a ser variado, a qual permanece } \\
\text { muito próxima aos graus da estrutura padrão } \\
\text { - Cada grau da estrutura padrão é constantemente } \\
\text { repetido duas ou três vezes dentro de seu compasso }\end{array}$ \\
\hline
\end{tabular}

Tabela 1.1: Diferenças entre a Folia e Folias de Espanha (HUDSON, 1982, p.xvi-xvii). 


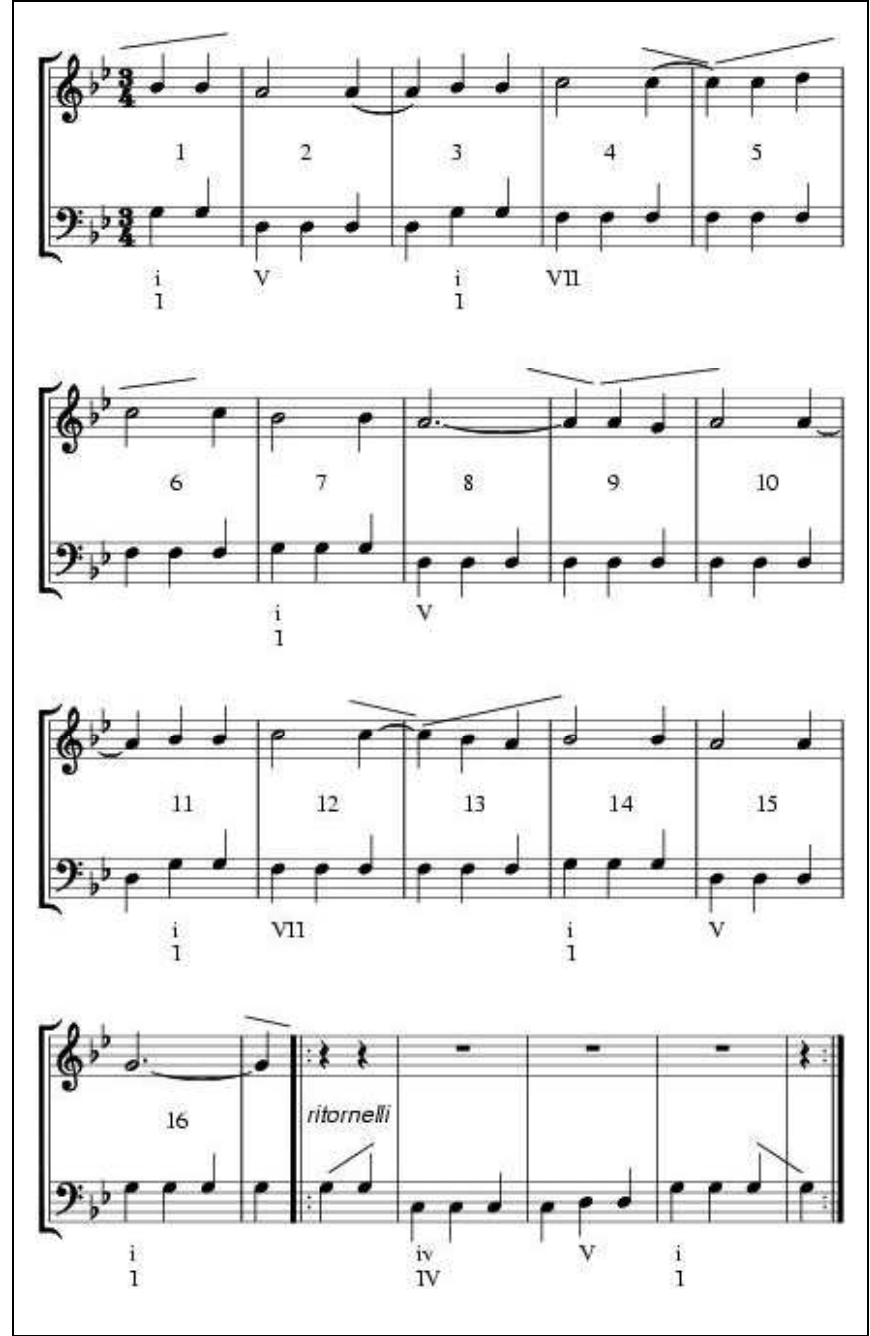

Fig. 1.20: Hudson: Folia ${ }^{68}$

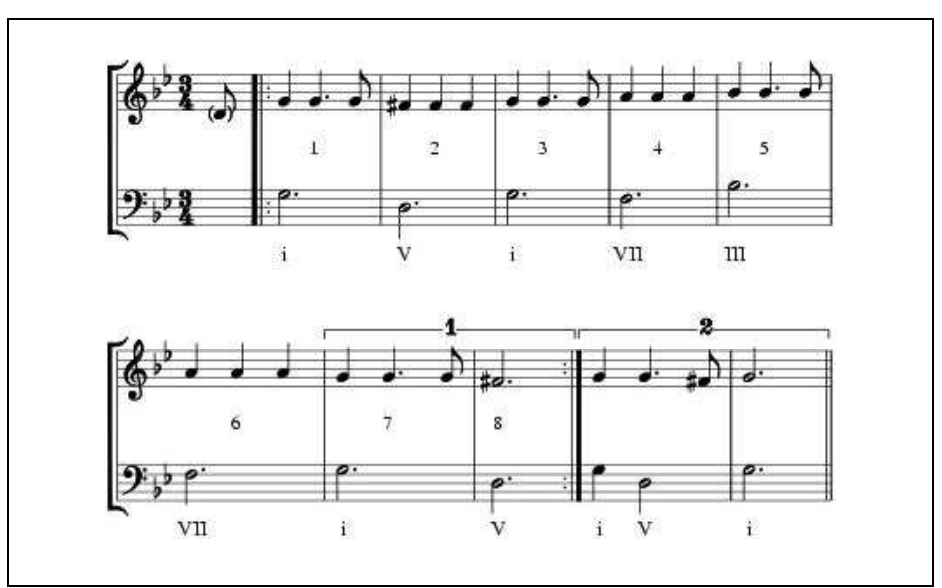

Fig. 1.21: Hudson: Folias de Espanha ${ }^{69}$

${ }^{68}$ HUDSON, 1980, p.691.

${ }^{69}$ Ibid., loc. cit. 


\subsection{A Folia ascende às cortes da França e Inglaterra}

É possível que o maior responsável pela propagação da guitarra de 5 ordens e da Folia como acompanhamento tenha sido o italiano Francesco Corbetta, que trabalhou algum tempo como músico na corte do rei Luís XIV, antes de se transferir para Londres. Suas versões da Folia já contém a linha de baixo característica em métrica ternária, com o segundo tempo pontuado em cada compasso, o que se tornou uma marca característica do tema desde então e o aproximou do ethos solene típico das danças de corte como a sarabande e a ciaconna.

Conhecemos cinco livros para guitarra de 5 ordens publicados por Corbetta. Seu primeiro volume contém quase que exclusivamente danças em rasgueado, enquanto que os últimos demonstram grande habilidade na combinação entre os toques dedilhado e rasgueado. Além disso, observamos uma transição de estilo na música de Corbetta, que inicialmente se enquadra no estilo italiano, mas que nas últimas obras revela firmemente o estilo francês.

Todos os livros de Corbetta contém variações sobre a Folia, sendo que a primeira versão data de 1643. O quatro livro de Corbetta, publicado em 1648 em Bruxelas, Varii scherzi di sonate per le chitara spagnola contém um conjunto de variações que demonstra a versatilidade nos dois estilos de execução em que Corbetta tornou-se especialista: iniciando-se com o rasgueado na parte prima e parte secunda, prosseguindo em punteado (dedilhado) nas três últimas sessões.

As variações mais importantes são aquelas do livro La Guitarre Royalle ( $L a$ Guitarre Royalle Dediee au Roy de la Grande Bretagne), que é a peça mais longa escrita por Corbetta. Nela detectamos, pela primeira vez, a apresentação do tema, já em ré menor, e em sua forma de sarabanda com o segundo tempo acentuado e pontuado, com sete 
variações contrastantes que exigem do intérprete considerável habilidade técnica ${ }^{70}$. Rui

Vieira Nery esclarece esse ponto:

Corbetta parece ser um dos primeiros autores a sobrepor a característica melodia aguda em tempo ternário ao baixo tradicional da Folia, com o segundo tempo pontuado em cada compasso, que ficaria associada ao gênero do final do século XVII em diante. Na verdade, a versão de 1674 de Gaspar Sanz era basicamente uma adaptação da publicação de Corbetta, que o mestre espanhol deve ter adquirido logo após sua edição em Paris. (NERY, 2005, tradução nossa). ${ }^{71}$

Giancarlo Rado enfatiza a importância de Corbetta na história da Folias de Espanha, ressaltando que:

A versão de Corbetta desta forma [Folia] é um vínculo vital entre a Follia anterior
e a posterior, que permaneceu em uso ao longo do século 18. Ela foi publicada
em Paris, onde Corbetta fora convidado por Luís XIV, na mesma época que
Michel Farinel e Arcangelo Corelli visitavam a cidade. Ambos compuseram
variações sobre esse celebrado tema, que prosseguiu como modelo por
compositores de toda a Europa. (RADO, 2005, tradução nossa). ${ }^{72}$

Por volta da década de 1630, algumas versões italianas para guitarra da Folia começaram a incluir variantes melódicas, consolidando-se como parte estrutural do tema ${ }^{73}$. Duas versões de Corbetta de 1639 possuem um interessante discanto.

Na década seguinte surge um novo estilo melódico na linguagem guitarrística que combinava notas dedilhadas com acordes rasgueados, e mais uma vez a Folia é utilizada como ponto de partida para variações ${ }^{74}$, porém com bem menos exemplos após a década de

\footnotetext{
${ }^{70}$ LINDBERG, 1997.

${ }^{71}$ NERY, 2005. No original: "Corbetta seems to be one of the first authors to superimpose to the traditional bass of the Folia the characteristic treble melody in triple meter, with a dotted second beat in each measure, that was to become associated with the genre from the late seventeenth century on. In fact, Gaspar Sanz' 1674 version was basically an adaptation of Corbetta's setting, which the Spanish master must have acquired shortly after its publication in Paris."

${ }^{72}$ RADO, 2001. No original: "Corbetta's version of the form is a vital link between the early Follia and the later, which remained in use throughout the whole of the 18th century. It was printed in Paris, Corbetta having been invited there by Louis XIV, at the very time when Michel Farinel and Arcangelo Corelli were visiting the city. Both composed violin variations on this celebrated bass line, which went on to be used as models by composers all over Europe."

${ }^{73}$ HUDSON, 1982, p.xxi.

${ }^{74}$ Cf. as obras: Folias sopra l'0 com parti variate e Fulias com parti variate (c.1640) de Foscarini; Follia (c.1640) de Bartolotti; Follia (1643) e Follias (1648) de Corbetta.
} 
1650. Outros instrumentos também apresentavam recorrências do mesmo tema nesta nova configuração.

A alteração mais expressiva na constituição da nova versão da Folia está associada ao aspecto rítmico: o segundo tempo pontuado, introduzido por Falconieri ou Corbetta, torna-se o principal elemento de vitalidade e variedade rítmica da Folias de Espanha. As obras de Corbetta exerceram um papel determinante na transmissão da Folia na França, já com todos os elementos característicos da nova roupagem do tema, agora definitivamente batizado como Folies d'Espagne.

Corbetta instalou-se em Paris em 1656, no auge da moda da guitarra de 5 ordens nas cortes de Luís XIV em Paris e de Carlos II em Londres, após ter participado como músico num balé composto por Jean-Baptiste Lully (1632-1687) para o rei. Sabe-se que Lully também tocava a guitarra, assim como o próprio Luís XIV, que a considerava seu instrumento favorito, tendo tido como professor um dos mais importantes instrumentistas da época, Robert de Visée (1650-1725). Por essa razão, Corbetta desfrutou de grande prestígio nas cortes francesa e inglesa.

Um ano após a publicação em Paris do livro de Corbetta dedicado a Carlos II, que incluía as duas versões da Folia de 1671 citadas anteriormente, o monarca francês solicitou a Lully que escrevesse um arranjo da Folia para seus músicos do regimento real. No manuscrito de Lully aparece o seguinte texto: fait par Mr. de Luly ...par ordre du Roy l'an 1[6]72, Philidor l'aîne em ayant reçeu l'ordre du Roy à St. Germain-en-laye pour le porter à Mr. de Luly, (LWV 48). De acordo com Hugo Reyne ${ }^{75}$, a nova Folias de Espanha foi incorporada ao repertório fixo do regimento real a pedido dos próprios oficiais, juntamente

\footnotetext{
${ }^{75}$ REYNE apud GABLER, 2008.
} 
com a Marcha do Regimento Real (1670) e a Marcha dos Mosqueteiros, tradicionalmente executadas desde a fundação do regimento.

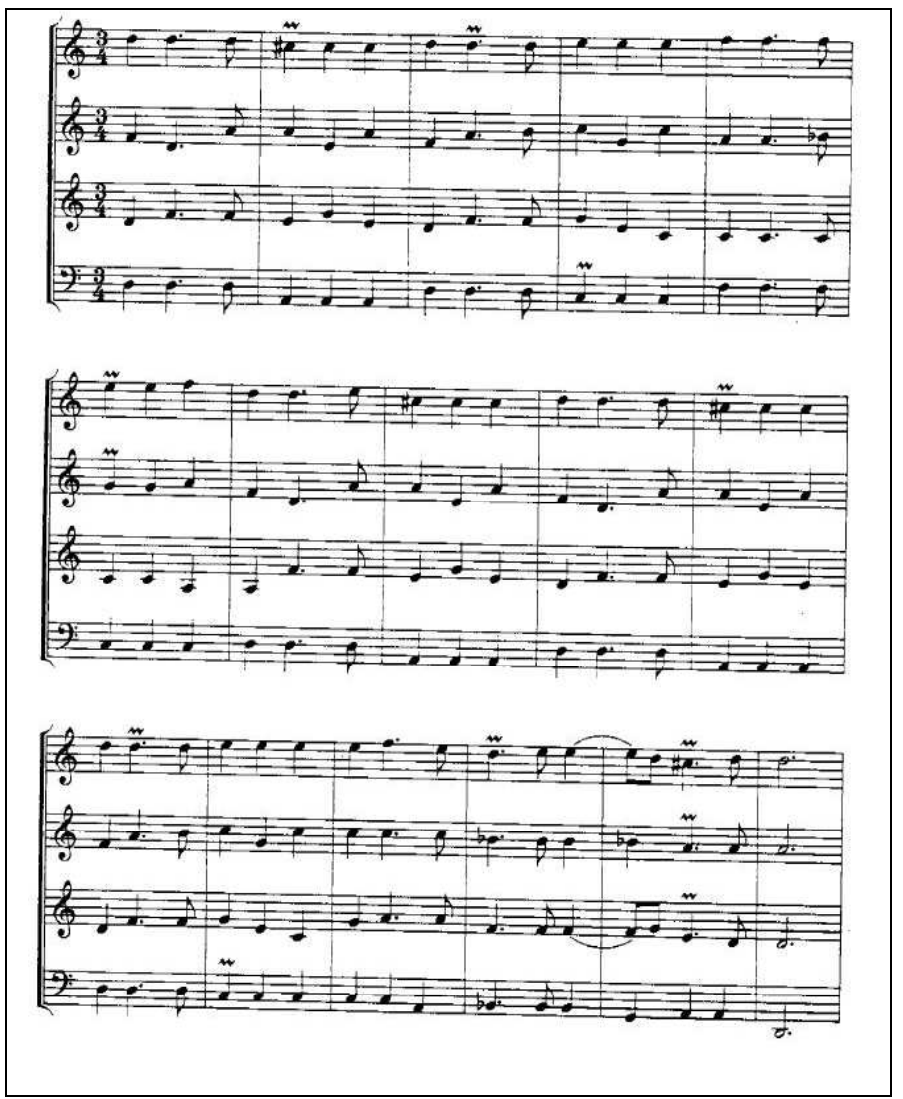

Fig.1.22: Lully: Air des hautbois Les folies d'Espagne para quatro sopros (1672).

A música resultante é considerada o primeiro exemplo oficial da estrutura típica da Folias de Espanha. Em 1674, Corbetta publica um livro de composições dedicadas a Luís XIV que contém uma Folia bastante simplificada e conservadora para a época: ênfase nos acordes rasgueados, barras duplas cuidadosamente alocadas para identificar a estrutura, e os dois acordes anacrúsicos claramente escritos. Presume-se que tais simplificações devam-se ao fato do guitarrista ter levado em consideração as modestas habilidades instrumentais do rei francês. 


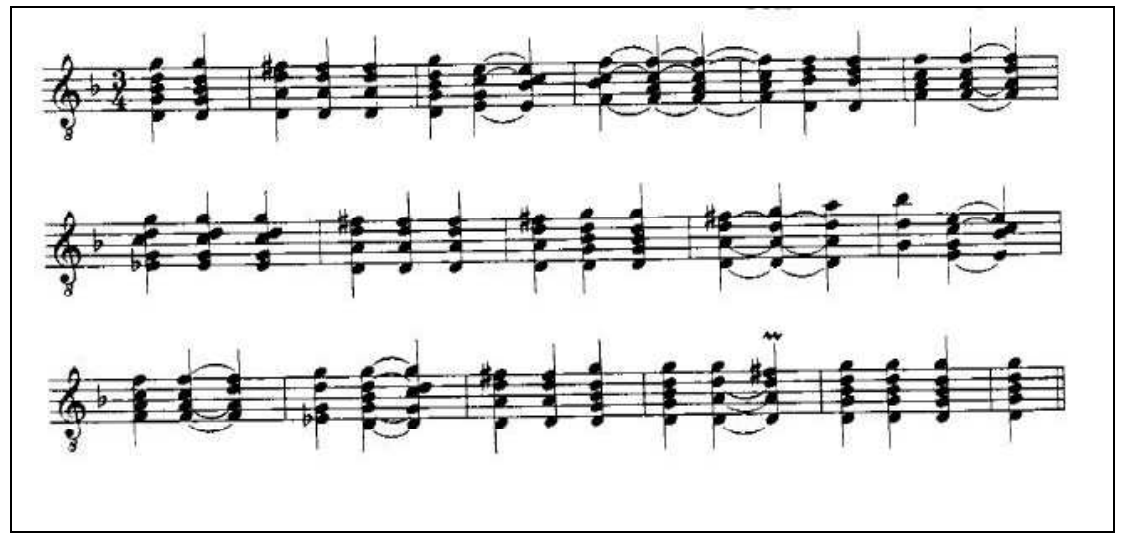

Fig.1.23: Corbetta, 1674.

É de se perguntar se, a partir da criação da música e da coreografia da Folias de Espanha, ela voltou a ser dançada na corte portuguesa, uma vez que Lully criou um estabelishment, tanto na ópera quanto na música de concerto, tomando como ponto de partida a dança. E como esse padrão foi adotado por toda a Europa, é preciso saber até que ponto a corte portuguesa adotou os critérios de Versailles para determinar a influência dessa música nas danças portuguesas.

Sabe-se que na corte portuguesa se praticava a dança barroca francesa, embora a Folias de Espanha - que mesmo na França não era dançada pelos nobres, mas por profissionais em virtude da complexidade da coreografia, e do uso de castanholas - não apareça em nenhuma coletânea encontrada conhecida. Como muita coisa se perdeu, então podemos apenas suspeitar que a Folias de Espanha como dança de corte poderia ter sido praticada em Portugal, dada a grande popularidade da dança e da música. 


\section{CAPÍTULO 2:}

APOGEU DE UM PATRIMÔNIO

UNIVERSAL DA ARISTOCRACIA 


\subsection{Contexto retórico na música dos séculos XVII e XVIII}

A retórica antiga é um sistema de regras que não apenas constituem, mas também organizam a eloquiência do discurso verbal, ou do bem dizer ${ }^{1}$. Sua etimologia provém do grego rhetoriké (rhetorica, em latim) e possuía duas tendências em suas origens: lógica e psicagógica. A primeira tratava de estabelecer um sistema de silogismos (dedutivos) e exemplos (indutivos) que tornassem o discurso razoável e lógico pela via da razão, enquanto que a segunda relacionava-se a um tipo específico de sedução irracional, cuja persuasão se fazia pela via do pathos (emoção) ${ }^{2}$. A retórica antiga findou por unir as modalidades lógica e psicagógica nas suas provas intrínsecas: logos (razão, argumentos lógicos), ethos (sentimento ou imagem de si próprio) e pathos (emoção e paixão). Cícero recomendava que orador deveria saber regular essa tríplice variedade para ter grande discernimento e extraordinárias qualidades ${ }^{3}$.

A corrente psicagógica provinha da tradição pitagórica, na qual a geometria (espaço), o cálculo (abstração) e a música (acústica) ocupavam os papéis de demonstração da essência numérica de todas das coisas e fenômenos. As demonstrações da onipresença numérica eram materializadas, representadas de forma concreta e, para tanto, valiam-se freqüentemente de figuras geométricas ou de elementos sólidos - como pedras - para efeitos de comprovações pelo aspecto visual, já que o conceito de abstração numérica é historicamente mais recente e característica do pensamento moderno ${ }^{4}$. Assim, a presença do número nesta tradição não é apenas um valor ontológico, mas também uma essência oculta, dotada de poderes mágicos.

\footnotetext{
${ }^{1}$ HOUAISS, 2001, p.2447.

${ }^{2}$ Os retóricos das letras evitam o termo emoção, que implica em um sujeito individual, caracteristicamente pós-iluminista, preferindo termos não anacrônicos, como afeto, pathos, patético, etc.

${ }^{3}$ CÍCERO, 1991. \$100-103.

${ }^{4}$ TOMÁS, 2005, p.16.
} 
A onipresença numérica pitagórica e o poder mítico da palavra estavam intrinsecamente associados, pois, ao abandonar sua prerrogativa ontológica em prol das demonstrações concretas para efeitos didáticos, a palavra também teve de abrir mão de sua transcendência para cumprir com sua finalidade sofística de persuasão ${ }^{5}$. Lembrando que Aristóteles classificou três tipos de silogismos: apodítico (baseado em premissas verdadeiras), dialético (baseado em premissas verossímeis) e sofístico (baseado em premissas falsas).

Tal natureza sofística foi combatida pelo platonismo, que reivindicava uma atitude ética da retórica praticada pelos sofistas pré-socráticos, pois como técnica, poderia ser perigosamente administrada por pessoas de índole duvidosa, além do fato de que os mestres dessa arte eram, em sua maioria, estrangeiros e cobravam por seus serviços. Para Platão, a retórica deveria ser um meio de se conhecer a verdade, e nunca iludir o interlocutor por meio de sedutoras técnicas oratórias.

A sistematização da retórica e da poética por Aristóteles foi um verdadeiro marco na história, cuja influência atravessou todo o medievo e culminou até meados do século XVIII, devido às suas detalhadas organizações metodológicas. Autores posteriores, tanto do ramo da retórica (como Cícero e Quintiliano) quanto da poética (de Horácio a Boécio), foram influenciados pelo sistema aristotélico, quer tenham tido eles contato direto ou não com a obra do estagirita.

A retórica antiga se subdividia em três gêneros: laudatório, forense e político. O gênero laudatório é aquele que visa a aprovação do público, podendo ser da natureza de louvação (ode, panegírico) ou vitupério (sátira). Seu tempo está ligado ao presente. O gênero forense, ou judiciário, é aquele que resulta numa sentença de acusação ou de defesa,

\footnotetext{
${ }^{5}$ ASSUMPÇÃO, 2007, p.7.
} 
e remete-se aos acontecimentos do passado. O gênero político projeta seus objetivos a uma votação, ou mesmo a uma proposta de mudança (utopia), baseando-se em valores que oscilam entre o útil e o nocivo, visando o futuro. Vale ressaltar que tais gêneros não constituem formas puras, misturando-se os elementos de formas diversas, porém havendo sempre o predomínio de um deles: o laudatório resultando num julgamento subjetivo acerca do valor do discurso, o judiciário terminando na condenação ou absolvição de um réu e o político resultando na votação de uma determinada decisão ${ }^{6}$.

Podemos dizer que os fundamentos retóricos e poéticos das três principais tradições gregas - pitagórica, platônica e aristotélica - formaram a base de todo um sistema de pensamento interdisciplinar que iria penetrar de maneira irreversível em quase todas as áreas do conhecimento nas culturas romana, cristã medieval e, mais tarde, no Humanismo e no Luteranismo, perdendo seu fôlego apenas com o surgimento do Iluminismo.

A penetração da Poética de Aristóteles na música pode ser traçada por duas vias principais: a humanista, com o reaparecimento do primeiro volume na Europa do século XIV em traduções latinas e vernáculas, e a luterana, que enfatizou as disciplinas de música e de retórica no sistema de ensino da Lateinschule ${ }^{7}$.

A partir dessa estreita associação entre as duas disciplinas, especialmente na Alemanha reformada, fermentou-se um sistema de analogias e um modus operandi entre elas a ponto de não se pensar na música sem se remeter naturalmente à retórica.

\footnotetext{
${ }^{6}$ TRINGALI, 1988, p.57.

${ }^{7}$ BARTEL, 1998, p.7.
} 


\subsection{A tópica da loucura nas artes}

As idéias do furor, da loucura e da melancolia eram caras ao imaginário das artes na antiguidade, e representavam um dos lugares comuns da retórica antiga, usada como res ${ }^{8}$ em diversas obras na pintura, literatura e música. Possivelmente a origem dessa tópica remonte à tradição do furor na mitologia grega, sendo uma das mais antigas aquela em que Ájax disputa as armas de Aquiles após sua morte, mas que foram legadas a Ulisses, deixando o primeiro tão possesso que, durante a noite, massacrou todos os rebanhos do acampamento, imaginando que se tratava da tropa espartana. Desde então, o Furor transformou-se em tópica de vários mitos (Orlando, Hércules) e foi reproduzido em diversas obras artísticas (Lucrécia, Dom Quixote, etc). Cabe observar, aqui, que Erasmo de Rotterdam (1467-1536), fazia uma distinção qualitativa entre a loucura - de natureza alegre - e o furor - de característica perversa - inspirada pelas Fúrias da mitologia grega 9 .

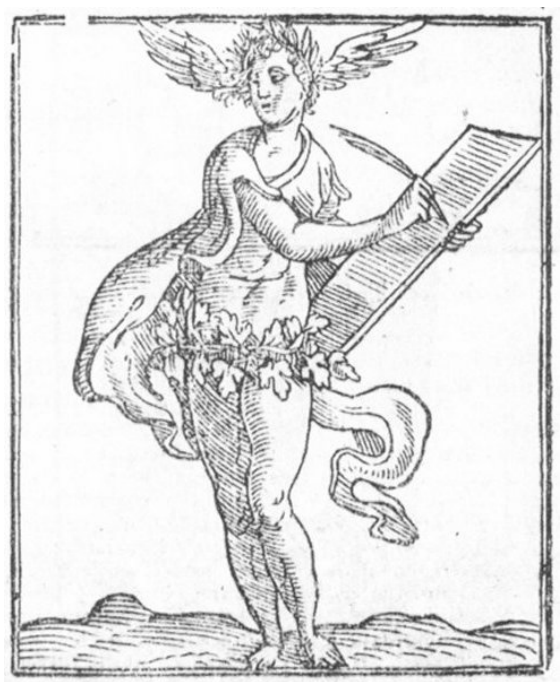

Fig.2.1: Cesare Ripa (1560-1622), Furor Poetico (1611).

\footnotetext{
${ }^{8}$ Res - substantivo latino que designa coisa, assunto - significa a matéria que será aboradada no discurso dentro do sistema da retórica antiga.

${ }^{9}$ ERASMO, 2003, p.61, passim.
} 
Em princípio, a loucura é tomada como falta de coerência no discurso, tendo sido também codificada retoricamente como estilo fantástico. Emanuele Tesauro (1592-1675), em seu tratado Cannocchiale Aristotelico, de 1652, afirma que a metáfora é a "mãe de todas as agudezas" e que ela pode ser invocada para fecundar as mentes humanas através de três formas: o engenho, o furor e o exercício. Para ele, o furor é uma alteração da mente causada por paixão, inspiração ou loucura. A paixão corresponde às disposições transitórias do espírito (como a raiva, o ciúme, a euforia) que afiam o gume do engenho humano e adicionam forças à persuasão. A inspiração refere-se a um tipo especial de entusiasmo, que geralmente acometia os profetas; portanto, existem dois tipos de poetas (artistas): os engenhosos e os inspirados. A loucura podia ser entendida pelo próprio mecanismo da metáfora: tomar uma coisa pela outra, sendo que os loucos eram considerados os mais belos exemplos de engenho. Acreditava-se, inclusive, que os engenhosos mais sutis, como os poetas e matemáticos, eram os mais propensos a enlouquecer. Tal como ocorre no gênero capricho da pintura, "nada é mais artificioso que pecar contra a arte, nada é mais sensato que perder o juízo"10 . A tópica da loucura foi elaborada também a partir de outras vias na inventio $^{11}$ - podendo abranger, na retórica, nas artes e na música, desde conexões meramente engenhosas até relações numéricas e místicas ${ }^{12}$, além da poética de Tesauro:

\footnotetext{
${ }^{10}$ TESAURO, p.1997, p.6.

11 O sistema poético-retórico geral clássico dividia o discurso em cinco categorias básicas: inventio, dispositio, elocutio, memoria e actio, e esse modelo foi integralmente adaptado às técnicas de composição musical dos séculos XVII e metade do XVIII. A primeira categoria trata da matéria do discurso (res), ou seja, um tema musical que deve conter em sua estrutura o afeto almejado pelo compositor. Na retórica antiga, a inventio tratava da busca de provas em um repertório prévio. Lembramos que a etimologia latina desse termo remete ao sentido de "encontrar", e era exatamente essa a tarefa do compositor: buscar, em meio a uma biblioteca de procedimentos musicais (esses paradigmas eram chamados de "lugares comuns", loci em latim ou topici em grego) o sentimento adequado para seu tema musical ou para ajustar perfeitamente uma melodia às palavras de um texto.

12 Ou seja, o próprio conceito de Agudeza. Sobre essa tópica, cf. a primeira parte do Cannocchiale Aristotelico, e os primeiros capítulos de Agudeza y Arte de Ingenio, em que o autor define agudeza.
} 
pela medicina antiga - o humor colérico da teoria dos humores ${ }^{13}$ - e pelo misticismo de tradição platônica, cujas diversas transformações medievais neo-platônicas - Cristianismo, Agostinanismo, Hermetismo - desembocam na teoria do humanista florentino Marsílio Ficino (1433-1499) de que o amor platônico só pode ser alcançado pelo estado da melancolia.

Assim, é possível que a Folias de Espanha não representasse tão somente uma temática enquadrada num lugar comum, mas uma tópica em si. O tema musical findou agregando, de forma engenhosa, diversos aspectos que tangiam desde a simples idéia de loucura até aspectos políticos e culturais: o furor controlado pela razão, representado por um tema musical de caráter selvagem que foi transformado em uma inofensiva e solene dança cortesã francesa e elegante; a sátira que vitupera a cultura ibérica; a folia ou loucura que eram associadas à Espanha, etc.

\footnotetext{
${ }^{13}$ A teoria remonta a Hipócrates (460-377 a.C.), antigo médico grego que formulou a idéia das substâncias básicas dos quatro tipos de temperamentos: fleumático (fleuma), sanguíneo (sangue), melancólico (bílis amarela) e colérico (bílis negra).
} 


\subsection{Considerações sobre os afetos da Folias de Espanha na música antiga}

Um dos aspectos mais importantes de um tema musical na música dos séculos XVI ao XVIII é a escolha adequada da tonalidade que melhor expresse o afeto que está sendo representado. As diferenças entre os modos maior/menor e os andamentos rápido/lento já são os indicativos iniciais de um pathos determinado. Ademais, o distanciamento ou proximidade da tonalidade de Dó maior - que era considerada a mais "pura" devido à ausência dos acidentes, sem mencionarmos os agravantes decorrentes da afinação justa - no círculo das quintas, podia revelar uma tendência a uma ambiência generalizada de euforia (sustenidos) ou tristeza (bemóis). Esse aspecto geral deveria ser sublinhado na execução prática.

Uma sofisticação mais detalhada desses parâmetros gerais e sua correlação entre a gramática musical e os afetos resultou em toda uma pesquisa de caráter empírico, embora se objetivassem resultados objetivos, dentro dos moldes científicos do século XVII ${ }^{14}$. Essa tentativa de sistematização dos efeitos patológicos da música é, hoje, batizada como Doutrina dos Afetos (Affektenlehre), muito polêmica em seus aspectos ontológicos. Assim, a combinação de andamento, tonalidade, modo, intervalos, tipos de acordes, combinações rítmicas, etc. formavam todo um sistema de códigos que era compartilhado entre os músicos e o público da época, de acordo com o estilo nacional ${ }^{15}$. A relação com a retórica antiga, aqui, é novamente transparente, pois cada procedimento musical tinha seu correspondente proveniente das figuras de retórica da tradição oratória: anaphora, anadiplosis, pleonasmus, etc.

\footnotetext{
${ }^{14}$ Cf. DESCARTES, 1999, passim.

${ }^{15}$ BARTEL, 1998, passim.
} 


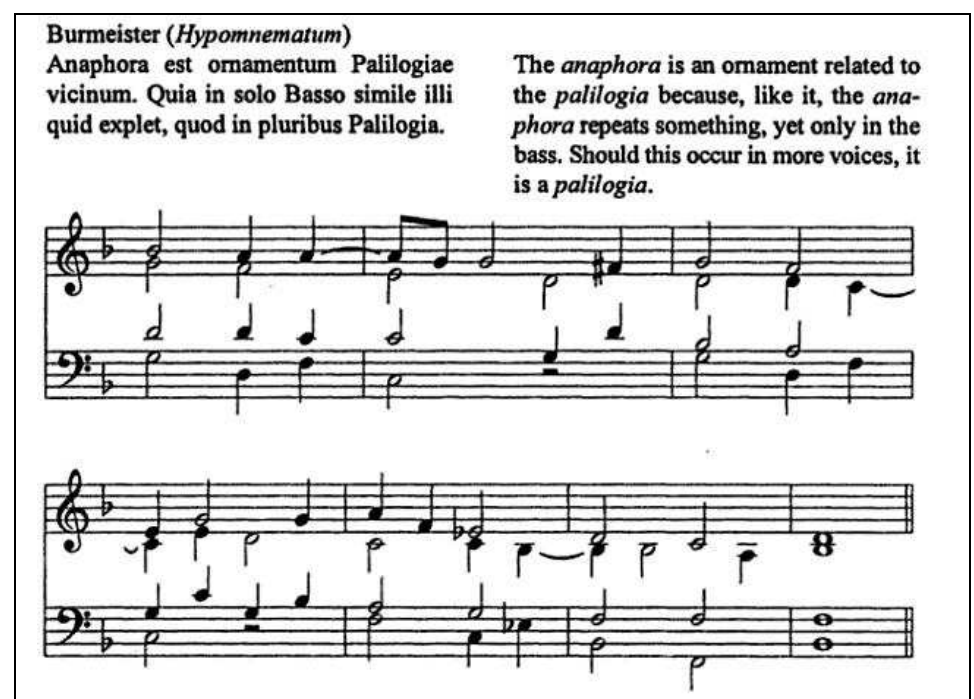

Fig.2.2: Exemplo de um procedimento retórico-musical, nomeado de acordo com a tradição da oratória clássica ${ }^{16}$.

Dessa maneira, poderíamos destacar os elementos mais importantes que provavelmente circundavam a Folias de Espanha, bem como seu antecedente, a Folia, dentro do contexto de uma análise retórico-musical.

Conforme descrito anteriormente, a Folia em suas origens de dança popular era tocada em tempo rápido, geralmente no tom de Sol menor, e cultivada inicialmente na Espanha e Itália entre os séculos XVI e meados do XVII. Sua moldura harmônica era recorrente em diversas tablaturas italianas e podia, dentro dos moldes estruturalistas que isolam as invariantes e as transformam em funções, ser resumida na seguinte seqüência:

\begin{tabular}{|l|l|l|l|l|l|l|l|l|l|l|l|l|l|l|}
\hline $\mathrm{i}$ & $\mathrm{V}$ & $\mathrm{i}$ & $\mathrm{VII}$ & $\mathrm{VII}$ & $\mathrm{VII}$ & $\mathrm{i}$ & $\mathrm{V}$ & $\mathrm{i}$ & $\mathrm{V}$ & $\mathrm{i}$ & $\mathrm{VII}$ & $\mathrm{VII}$ & $\mathrm{i}-\mathrm{V}$ & $\mathrm{i}$ \\
\hline
\end{tabular}

\footnotetext{
${ }^{16}$ BARTEL, 1997, p.187.
} 


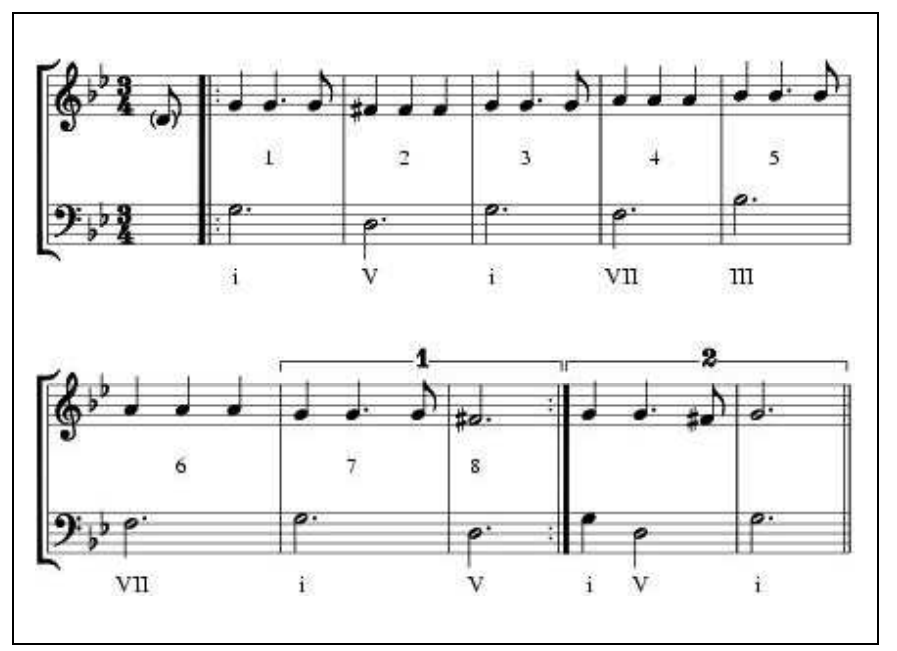

Fig.2.3: Tema básico da Folia

Conforme podemos observar no exemplo acima, seus impulsos melódicos são em tempos ternários (3/2) ou binário composto (6/4), com a thesis recaindo sobre o acorde de Dominante.

Considerando-se a visão afetiva dos autores do século XVII sobre as tonalidades, podemos inferir que uma dança rápida em Sol menor tinha uma característica que oscilava entre a doçura ${ }^{17}$, graciosidade e seriedade ${ }^{18}$, sendo que a partir do XVIII a mesma tonalidade passa a assumir um pathos mais amargo, associando-se tanto aos sentimentos de descontentamento quanto ao equilíbrio temperamentos (tristeza e alegria simultaneamente).

Já a Folias de Espanha que, como vimos, foi adotada como dança de corte na França e Inglaterra na segunda metade do século XVII, possui acento recaindo sobre a Tônica, e não mais sobre a Dominante (Folia), com mudanças significativas na estrutura rítmica. Era popularmente conhecida como de Folie(s) d'Espagne na França ou Farinelli's Ground na Inglaterra. A melodia desce do III grau à tônica, os compassos ímpares são

\footnotetext{
${ }^{17}$ RAMEAU, 1722, apud STEBLIN, 1996, p.278.

${ }^{18}$ MATTHESON, 1713, id., ibid.
} 
pontuados no $2^{\circ}$ tempo, razão pela qual Taubert e Mattheson a relacionam com a sarabande ${ }^{19}$.

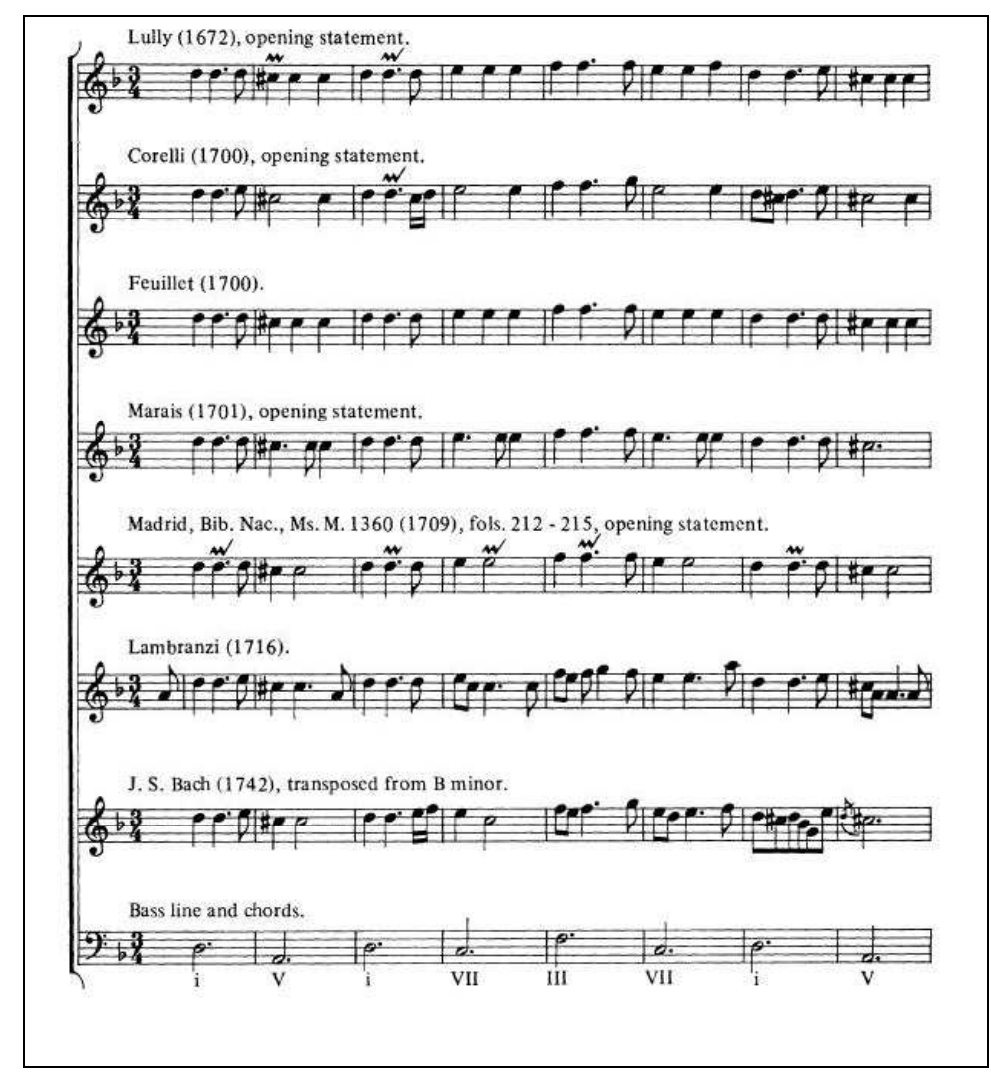

Fig. 2.4: tabela comparativa com os percursos melódicos e harmônicos de diversas versões do tema Folias de Espanha ${ }^{20}$.

Um aspecto importante, já mencionado anteriormente, reside em sua harmonia em espelho, em forma de palíndromo - figura retórica de metataxe, ou seja, uma alteração simultaneamente gramatical e de expressão de uma frase, de aplicação análoga à música com recorrência no tom de Ré menor, em tempo lento e solene.

\footnotetext{
${ }^{19}$ HUDSON, 1980.

${ }^{20}$ HUDSON, 1973, p.112.
} 
Sua moldura harmônica pode ser resumida na seguinte seqüência:

\begin{tabular}{|l|l|l|l|l|l|l|l|l|l|l|l|l|l|l|l|}
\hline i & V & i & VII & III & VII & i & V & i & V & i & VII & III & VII & i-V & i \\
\hline
\end{tabular}

O tom de Ré menor - associado ao modo Dórico, de pathos tipicamente sério e solene, em tempo lento adaptado à sarabande ou à passacaglia, era associado à devoção e seriedade no final do século XVII ${ }^{21}$, passando depois a representar o afeto mais cultivado do universo da música barroca: a melancolia. Os autores do século XVIII e do início do XIX são praticamente unânimes ao indicarem a natureza melancólica de Ré menor ${ }^{22}$, alguns chegando a adjetivá-la como "melancolia feminina"23. Mais tarde, o mesmo tom passa a assumir o caráter de tristeza ${ }^{24}$.

${ }^{21}$ CHARPENTIER, 1692, apud STEBLIN, 1996, p.242.

${ }^{22}$ GALLEAZZI, 1796; GRÉTRY, 1797; LICHTENTHAL, 1826; SCHRADER, 1827; WEICKART, 1827; GATHY, 1835; HAND, 1837, apud ibid., p.242 et seq.

${ }^{23}$ SCHUBART, 1784; SCHILLING, 1836, apud ibid., loc,cit.

${ }^{24}$ KNECHT, 1792; EDHARDT, 1830; GARDINER, 1817, apud ibid., p.224 et seq. 


\subsection{Afinidades entre a retórica e a forma tema e variações}

A relação entre a retórica e a forma Tema e Variações se deve não apenas à influência da primeira na produção musical dos séculos XVII e XVIII, mas principalmente aos dois elementos comuns à persuasiva retórica e à forma em questão: repetição e ornamentação $^{25}$.

Em 1793, o abade George Joseph Vogler (1749-1814) definiu a forma tema e variações como "um tipo de retórica, onde o sentido dado aparece em diferentes maneiras, com a diferença de que as linhas divisórias são muito mais rigorosamente determinadas na música do que na oratória,26.

$\mathrm{O}$ arcabouço da idéia de variações sobre um tema surgiu da ars praedicandi - ou seja, da técnica de oratória de pregação medieval, na qual o orador construía seu sermão a partir de uma citação das escrituras e, a partir dela, elaborava uma série de "divisões" que serviam para esclarecer e amplificar o sentido.

Uma das mais importantes fontes que ligam a variação com a retórica é o tratado de Erasmo sobre a cópia das palavras e das idéias, de $1512^{27}$. Nele, o humanista ressalta a importância de dizer a mesma idéia de modos diferentes, e inclui procedimentos de variações em uma lista de figuras. Como exemplo, demonstra a possibilidade de 200 variações sobre a frase "eu me lembrarei de você enquanto eu viver" e 150 sobre "sua carta agradou-me imensamente": "sua epístola alegrou-me intensamente", "suas páginas engendraram-me um deleite incomum"; "sua carta expeliu imediatamente todas as tristezas

\footnotetext{
${ }^{25}$ SISMAN, 2009.

${ }^{26}$ VOGLER apud SISMAN, 2009, tradução nossa. No original: "Variations are a type of musical rhetoric, where the given meaning appears in different guises, with the distinction that the boundary lines are much more rigorously determined in music than in oratory."

${ }^{27}$ ERASMUS, 1999.
} 
de minha mente", "eu morreria se algum dia encontrasse algo em toda minha vida mais agradável que sua carta", etc ${ }^{28}$.

A grande vantagem do recurso da variação, para Erasmo, é que o orador evita a repetição literal, tida por ele como uma grave falha, pois a "natureza, acima de tudo, deleita-se na variedade" 29 .

Os problemas referentes à técnica da variação são praticamente os mesmos na retórica e na música. Os teóricos das duas áreas recomendam que a aplicação das figuras é um recurso natural e necessário, porém não deve ser exagerado. A tensão decorrente entre res e verba, ou seja, como um pensamento pode ser revestido por palavras ou sons, é maior na música do que na retórica, pois o próprio tema já possui uma "roupagem" - algumas variações antigas trazem o primeiro segmento indicado como prima variatio $^{30}$.

As figuras de retórica musical possuem a função de adornar e tornar mais expressiva uma entidade musical simples, da mesma maneira que na retórica verbal. A simples repetição variada pode ser considerada não apenas como uma demonstração de domínio de estilo como também uma figura de retórica que inclui novas figuras. Por exemplo, a figura de retórica verbal conhecida como expolitio consiste em dizer algo prolongando-se no mesmo assunto e, ainda assim, parecer que algo novo está sendo dito. Um exemplo de discurso baseado nesta figura é aquele que o tema é exposto de maneira simples, depois reelaborado em um novo formato, seguido de argumentos de comparação, contestação e exemplo, e uma conclusão que retome o assunto principal. Diversas formas musicais são

\footnotetext{
${ }^{28}$ ERASMUS, 1999, p.38-42.

${ }^{29}$ Id., 1963, p.14.

${ }^{30}$ SISMAN, 2009.
} 
provenientes da expolitio, como a aria da capo barroca ou a sonata clássica, ou mais especificamente, a forma tema e variações do século XVII ${ }^{31}$.

As correspondências entre a forma tema e variações e a técnica retórica de variação revelam os elementos de exposição de idéias comuns a ambos em seus aspectos persuasivos e expressivos.

${ }^{31}$ SISMAN, 2009. 


\subsection{Auge da popularidade em variações virtuosísticas}

A Folias de Espanha circulou amplamente pela Europa durante os séculos XVII e primeira metade do XVIII como tema favorito para improvisações e composições na forma tema com variações de característica virtuosística, inicialmente na França, depois na Alemanha, Holanda e Inglaterra. Simultaneamente, os tratados de coreografia franceses e italianos de maior prestígio da época - tais como o do coreógrafo francês Raoul Auger Feuillet (Chorégraphie, 1700) e o do veneziano Gregorio Lambranzi (Nuoua e curiosa scvola de' balli theatrali, 1716) - contribuíram para a disseminação da versão coreográfica da Folias de Espanha por todo o mercado editorial europeu.

As danças de corte desenvolveram-se a partir de modelos rurais, simples e despretensiosos na coreografia, com amplo uso da improvisação nos passos e na música de acompanhamento. Durante os séculos XV e XVI elas saíram de seus contextos originais para as realidades palacianas, tornando-se cada vez mais padronizadas, tecnicamente mais complexas, despidas de quaisquer traços de suas origens camponesas, e completamente adaptadas ao gosto refinado de seus novos praticantes e espectadores, ou seja, findaram por pertencer ao domínio dos profissionais da dança, compositores e virtuoses. A dança barroca distanciou-se consideravelmente do acento popular, apenas mantendo algumas formas "geométricas", como no caso das contradanças, gerando dois tipos de situação: a dança da corte, em que predominavam as coreografias mais simples, e a dança teatral, onde as coreografias mais complicadas eram feitas por profissionais, com exceção de alguns nobres que também se destacavam. 


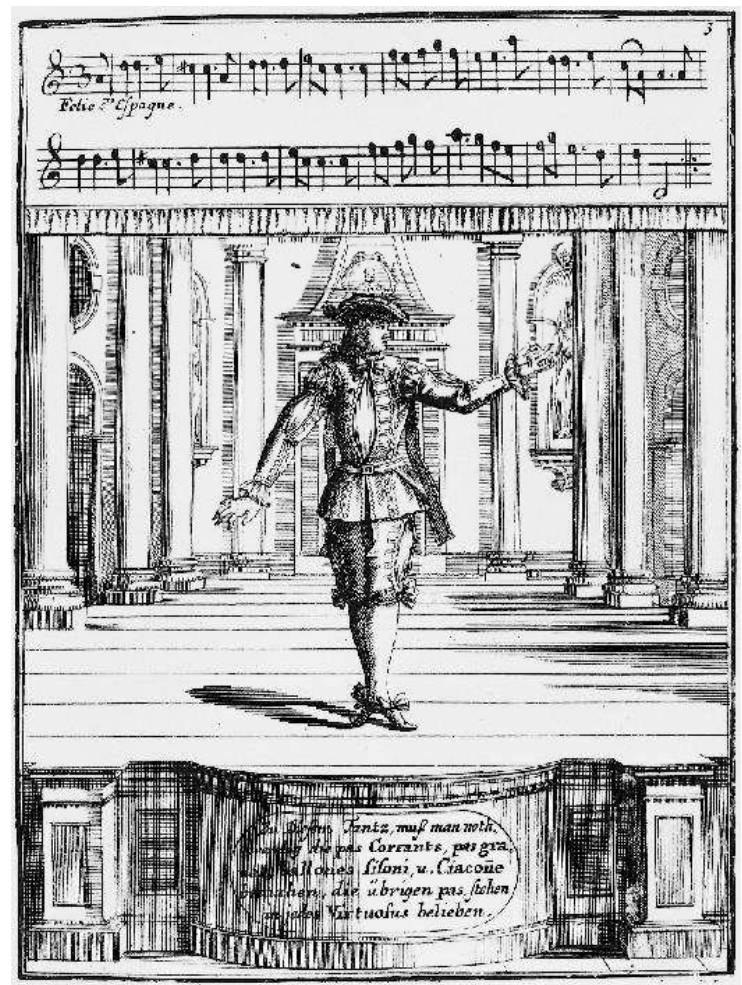

Fig.2.5: Frontispício do tratado de dança Nuoua e curiosa scvola de' balli theatrali de Gregorio Lambranzi (Nuremberg, 1716), estampado com o incipt musical da Folias de Espanha.

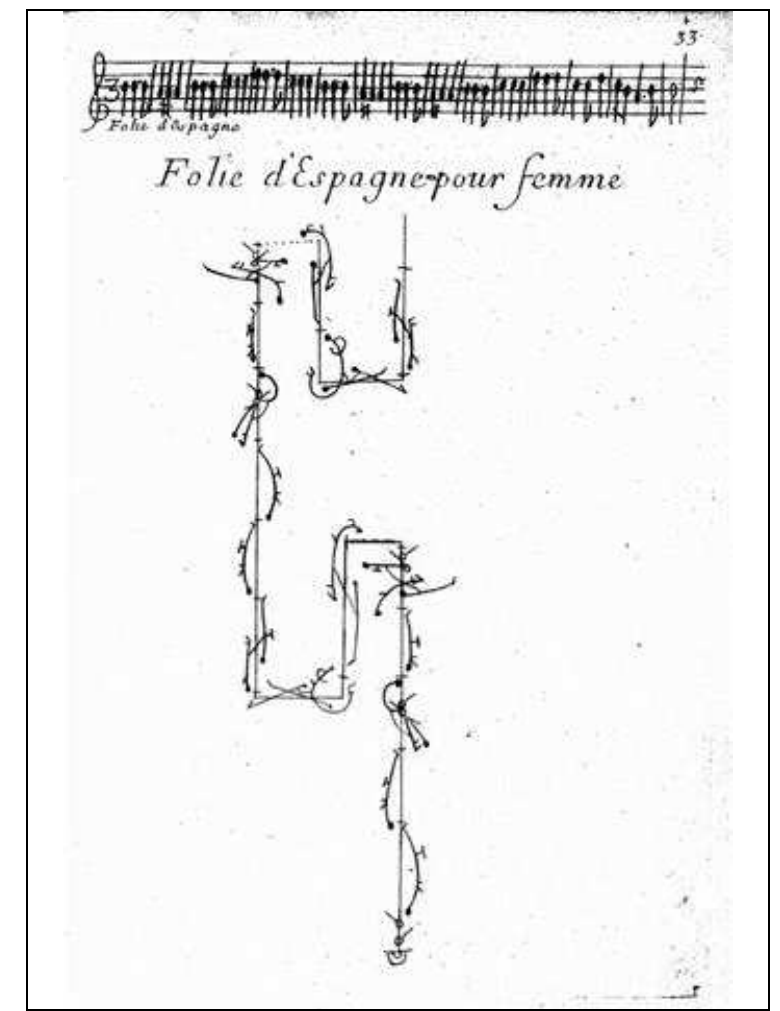

Fig.2.6: Coreografia da Folias de Espanha, Feuillet (1709). 
O editor inglês John Playford (1623-1686) incluiu variações sobre a Folias de Espanha para violino e contínuo escritas por Michel Farinel (1649-1726) - violinista e compositor, tio do famoso castratto Carlo Maria Broschi (Farinelli) - em sua coleção de música instrumental chamada The Division Viol (Londres, 1685), com o título de Faronell's Divisions. As variações de Farinel foram tão bem recebidas na Inglaterra que logo a Folias de Espanha ficou conhecida naquele país como Farinell (ou Faronell) Ground ${ }^{32}$. O mesmo tema foi utilizado também diversas em canções inglesas de caráter satírico, como, por exemplo, a canção Joy to great Caesar, de Tom Durfey (1653-1723).

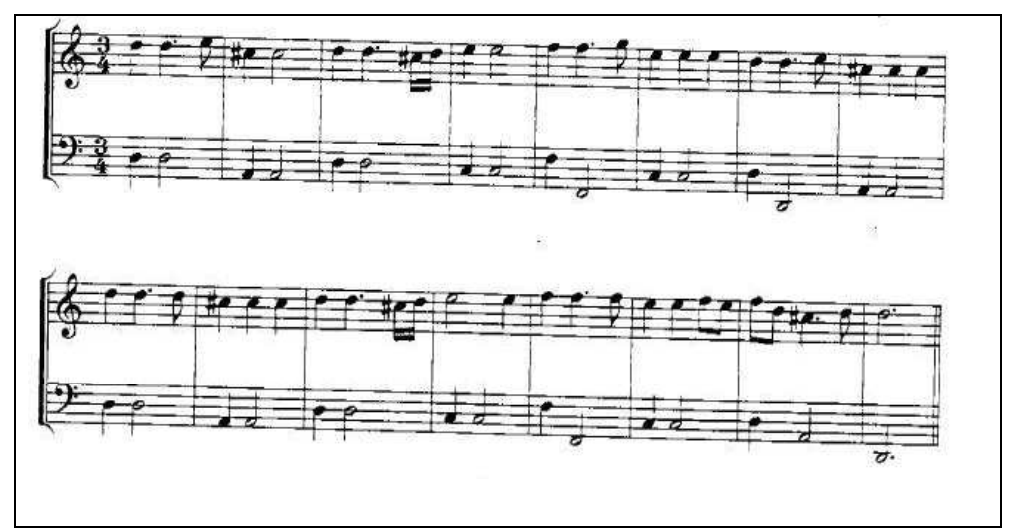

Fig.2.7: Farinell, 1685 .

Durante a metade do século XVII a Itália reagiu às extravagâncias dos violinistas virtuoses com um estilo mais sóbrio, sendo que a cidade de Bolonha foi um importante centro. Arcangelo Corelli (1653-1713) teve sua formação nesta cidade, embora tenha passado a maior parte da vida em Roma, e costumava incluir o título de il Bolognese em seus escritos e partituras autógrafas.

Corelli representa uma figura curiosa na história do violino: não era um grande virtuose, não viajava muito, compôs pouca música, mas sua influência na Europa foi

\footnotetext{
${ }^{32}$ NERY, 2005.
} 
estrondosa. Sua obra completa - quatro Trio Sonatas, uma Sonata solo e alguns Concerti Grossi - circulou por vários países como símbolo da composição barroca "clássica"33. A inovação de Corelli, entretanto, está no tratamento técnico do violino durante a consolidação da sonata de câmara, incluindo cordas duplas e triplas, escalas rápidas arpejos e passagens em estilo moto perpetuo. Essas sonatas para violino contêm um conteúdo fortemente didático, cuja influência está presente na música de Antonio Vivaldi (16781741) e de Giuseppe Tartini (1692-1770). Alguns contemporâneos e sucessores ultrapassaram seu estilo em termos de virtuosismo, mas nenhum na elegância de seu cantabile e no bom gosto com que evitou as meras exibições de dificuldades que não se justificassem pelo conteúdo musical ${ }^{34}$.

Corelli usou a Folias de Espanha como tema para a sonata com 23 variações que conclui sua mais importante coletânea de sonatas para violino e contínuo, as Sonatas Opus 5, sendo que a La Folia tornou-se conhecida por ter circulado por dez anos em sua versão manuscrita antes de sua publicação, em 1700. Trata-se da obra mais difícil de todo o repertório do compositor italiano, pelo menos no que se refere ao manejo do arco. A popularidade das sonatas de Corelli deu um forte impulso para a consolidação definitiva da Folias de Espanha no repertório da música instrumental durante o final do barroco, seguindo-se dois importantes ciclos de variações (de Vivaldi e Marais) em menos de cinco anos.

\footnotetext{
${ }^{33}$ STOWELL, 1992 p.49 et seq.

${ }^{34}$ GROUT \& PALISCA, 1997, p.409.
} 


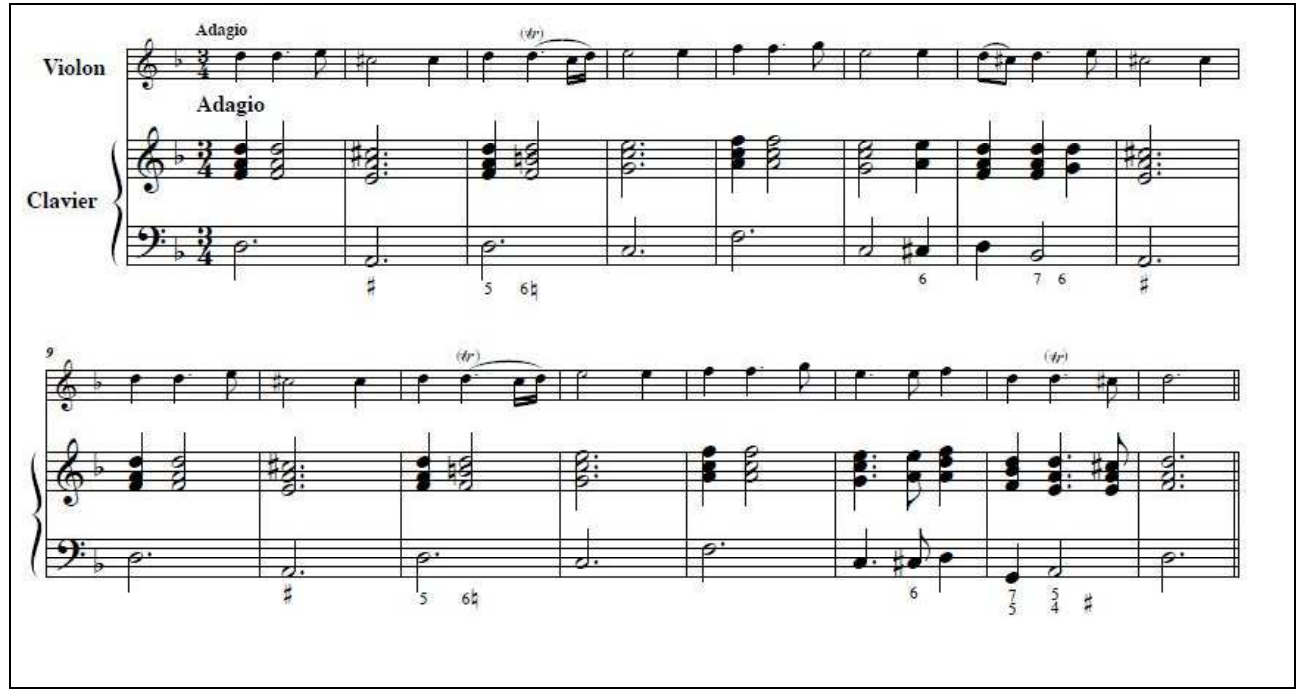

Fig.2.8: Corelli: Sonata 12 - La Folia (1700), tema.

A análise dos procedimentos de variação na tabela abaixo demonstra que as variações de Corelli privilegiam o desdobramento do tema Folias de Espanha em diversos tipos de arpejos sobre tríades e suas inversões:

\begin{tabular}{|c|c|}
\hline & CORELLI Op.5/12 \\
\hline Tema & Sarabanda \\
\hline I & Tríades (incompletas) ascendentes \\
\hline II & Tríades em arcos \\
\hline III & Imitação (violino/contínuo); mudança de perfil (tercinas) \\
\hline IV & $3^{\text {as }}$ com arpejos em arcos; mudança de perfil (tercinas) \\
\hline $\mathrm{V}$ & Cravo repete perfil da variação IV (violino: $3^{\mathrm{a}}$ e tônicas) \\
\hline VI & Arpejos ("batterie”) \\
\hline VII & Contínuo repete perfil da variação VI (violino: $3^{\mathrm{a}}$ e tônicas) \\
\hline VIII & Arpejos descendentes; mudança de perfil \\
\hline
\end{tabular}




\begin{tabular}{|c|c|}
\hline IX & Diálogo (violino/ contínuo) \\
\hline $\mathrm{X}$ & Arpejos ascendentes $(3 / 8)$ \\
\hline XI & Contínuo solo (graus conjuntos), violino $3^{\text {as }}$; compressão rítmica (4/4) \\
\hline XII & Arpejos descendentes $(3 / 8)$ \\
\hline XIII & Arco \& escala descendente $(12 / 8)$ \\
\hline XIV & Cravo solo (estaticidade); extensão rítmica (adagio); retorno ao 3/4 \\
\hline $\mathrm{XV}$ & $\begin{array}{l}\text { Inversão: violino repete perfil da variação XIV (nova figuração de arpejos em tercinas no } \\
\text { contínuo) }\end{array}$ \\
\hline XVI & Arpejos acendentes acéfalos; contínuo solo (inversão de perfil) \\
\hline XVII & Síncopas e saltos \\
\hline XVIII & Arpejos descendentes (extensão de $8^{\mathrm{a}}+5^{\mathrm{a}}$ ); mudança de perfil (ascendente) \\
\hline XIX & Imitação violino/contínuo (cânone) \\
\hline $\mathrm{XX}$ & Arpejos (ondulações); ritornello \\
\hline XI & Inversão: contínuo repete perfil da variação $\mathrm{XX}$; ritornello \\
\hline XII & Cordas duplas (saturação do arpejo) \\
\hline XIII & Inversão: contínuo varia perfil da variação XXII; extensão da coda (+4 compassos) \\
\hline
\end{tabular}

Tab.2.1: Perfis das variações da Sonata XII La Folia, de Corelli.

Existem especulações sobre a conexão entre os compositores Farinel e Corelli: Frederick Niecks (1845-1924) relata em um histórico artigo, publicado em 1888, que o violinista francês era mestre de capela em Hanover desde 1684, e que em 1690 Corelli que costumava viajar freqüentemente a Alemanha - havia visitado aquela cidade e recebeu 
das mãos de Farinel uma linha de baixo como desafio para que ele compusesse variações ${ }^{35}$. Entretanto, a falta de fontes primárias do autor do artigo na época pode colocar em dúvida a supracitada ligação entre os mestres francês e italiano, e talvez o relato tenha sido produzido com a finalidade de gerar um "pedigree" para as variações de Corelli, pois sabemos que naquela época não era tão difícil de se ouvir esse tema, tanto na Itália quanto em qualquer parte da Europa.

No ano seguinte à edição das Folias de Corelli, Marin Marais (1656-1728), celebrado músico das cortes dos reis Luís XIV e XV, publicou sua Les Folies d'Espagne, tema com 31 variações denominadas couplets. As variações são partes integrantes da coleção Pieces de Viole, 2e livre (Paris, 1701), entretanto, é possível que a composição da obra tenha ocorrido muito antes, uma vez que este foi discípulo direto de Lully, que, como sabemos, havia escrito sua Folies d'Espagne há menos de 30 anos. Durante seu período de aprendizado com Monsieur de Sainte-Colombe (1640-1693) ${ }^{36}$, na década de 1670, Marais presenteou seu colega Harie Maule - um nobre escocês que também era discípulo do mesmo mestre - com várias partituras autógrafas que foram posteriormente levadas a Edimburgo $^{37}$. Dentre elas, há uma versão preliminar manuscrita da Folies d'Espagne, porém sem os baixos cifrados.

\footnotetext{
${ }^{35}$ NIECKS, 1888, p.719.

${ }^{36}$ No filme Tous les matins du monde (1991) de Alain Corneau há uma cena em que o mestre Sainte-Colombe solicita ao então discípulo Marais que improvise sobre o tema Folias de Espanha para avaliar seu mérito artístico. O filme foi baseado no livro homônimo de Pascal Quignard, com Jean-Pierre Marielle no papel de Sainte-Colombe.

37 Recentemente, o gambista norte-americano John Hsu divulgou três manuscritos de Marin Marais depositados na Livraria Escocesa de Edimburgo, que continham aproximadamente 150 peças, sendo 40 delas inéditas. Entretanto, todas elas são apenas simples rascunhos de obras que apareceriam posteriormente em suas publicações de 1686, 1701 e 1711. Alguns registros apontam a existência dessa coleção na Escócia antes de 1685, ou seja, antes mesmo da publicação de seu primeiro volume, o Premier Livre, de 1686 (DUNFORD apud GABLER).
} 
Se nas variações de Corelli o tratamento técnico do violino é mais conservador, as de Marais são verdadeiros exemplos de engenho instrumental: a tonalidade de Ré menor explora uma ampla paleta de timbres da viola da gamba, além do uso da extensão total do instrumento, demandando um profundo conhecimento do intérprete para superar as dificuldades de muitas passagens.

François-Pierre Goy esclarece que:

Um manuscrito autógrafo de aproximadamente 1680 contém um primeiro esboço da 'Couplets de folies', a qual Marais deve ter provavelmente revisado gradualmente e enriquecido até a publicação em seu segundo livro de peças para viola da gamba (1701) [...]. Este distante eco da tradição inglesa de 'divisões sobre um ground' introduzida na França por André Maugars - é a única obra de Marais a fazer uso de um tema emprestado, na verdade um esquema harmônico afirmado na Espanha desde meados do século dezesseis e extremamente popular na França do último quarto do século dezessete em diante. A versão de Marais, uma das mais notavelmente longas e variadas elaborações do tema, iguala-se àquelas de seus predecessores franceses, como o alaudista Jacques Gallot e os cravistas Jean-Henry d'Anglebert e Marc-Roger Normand Couperin, e com a celebrada sonata 'La Follia' de Corelli, publicada em 1700. Marais explora os registros do instrumento e joga com as arcadas e tempos contrastantes. O baixo emerge frequentemente de seu papel de simples suporte harmônico para travar diálogo com a linha solista ou acompanhamento em terças. (GOY, 2006, tradução nossa). ${ }^{38}$

Marais escreveu, no prefácio de seu segundo livro, que a maioria das peças poderiam ser executadas em muitos outros instrumentos, como o órgão, o cravo, a guitarra ou a flauta transversal.

\footnotetext{
${ }^{38}$ No original: "An autograph manuscript from around 1680 contains a first draft of the 'Couplets de folies', which Marais must have gradually revised and enriched until the publication in his second book of viol pieces (1701) of the version recorded here. This distant echo of the English tradition of 'divisions on a ground' introduced to France by André Maugars - is the only work by Marais to make use of a borrowed theme, in fact a harmonic scheme attested in Spain since the mid-sixteenth century and extremely popular in France from the last quarter of the the seventeenth onwards. The version by Marais, one of the most strikingly extensive and varied elaborations of the theme, stands up well to comparison with those of his French predecessors such as the lutenist Jacques Gallot and the harpsichordists Jean-Henry d'Anglebert and MarcRoger Normand Couperin, and with Corelli's celebrated sonata 'La Follia', published in 1700. Marais exploits all the instrument's registers and plays on contrasting bowings and tempos. The bass often emerges from its role of simple harmonic support to engage in dialogue with the solo line or accompany it in thirds."

GOY, François-Pierre. Marin Marais: Les Folies d'Espagne, Suite en mi, Le Labyrinthe. Ensemble Spirale, Marianne Muller viola da gamba and conductor. France: Zig-Zag Territoires, 2006.

RADO, Giancarlo. Libreto do CD Folia from La guitarre royalle, Paris 1671. Tradução inglesa de Kenneth Chalmers. Erato Disques, Paris, 2001.
} 
Em 1704, Henricus Albicastro ${ }^{39}$ (1660-1730) - um dos maiores exponentes da música violinística alemã e holandesa - publicou a sonata La Follia, com uma escrita virtuosística inspirada em Corelli. E não foi por acaso que o Opus 1 (1705) de Antonio Vivaldi também finalizou sua primeira coleção de Trio Sonatas com um esplêndido conjunto de variações sobre a Folias de Espanha, cujo interesse reside na transição de seu típico caráter solene setecentista para a selvageria de sua versão antiga (a Folia de tradição ibérica) aumentando gradualmente seu andamento e a dificuldade das variações.

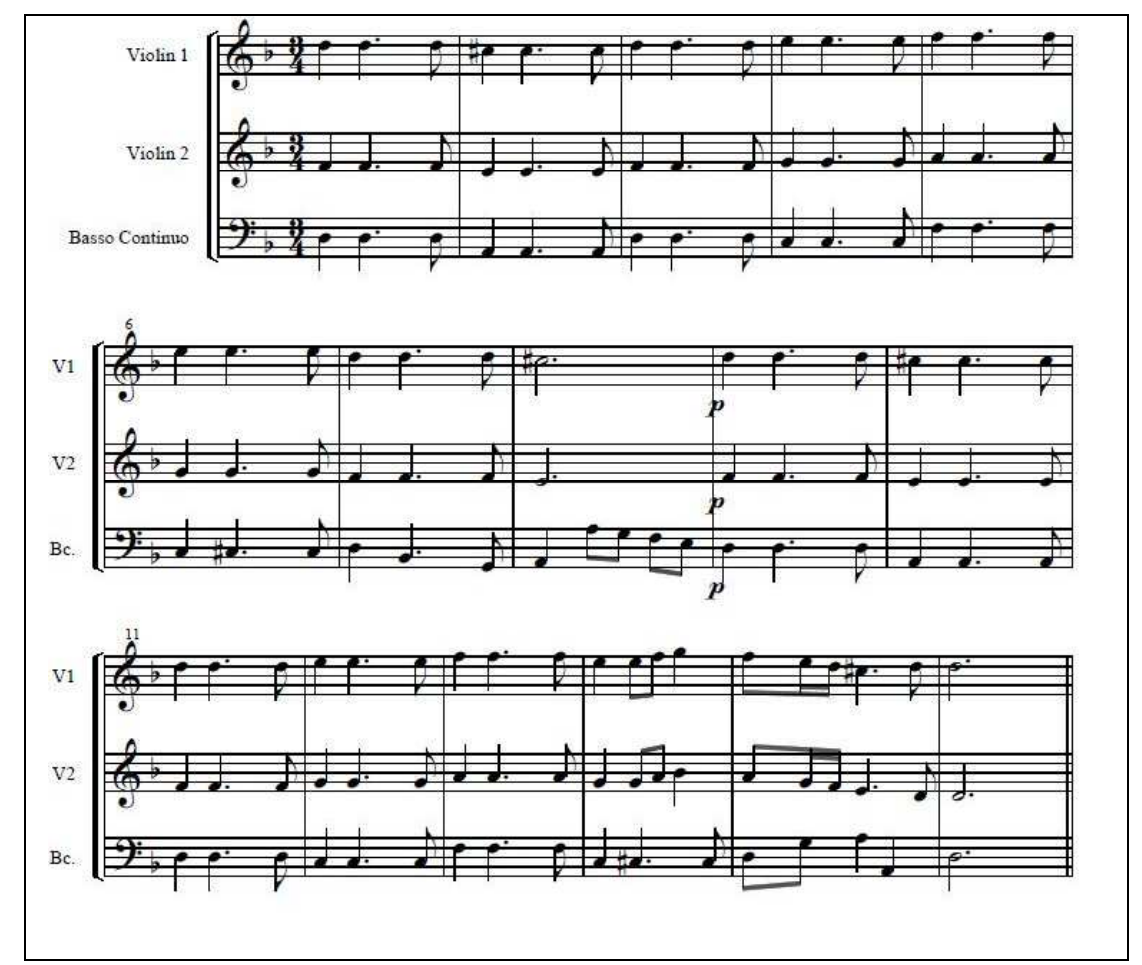

Fig.2.9: Vivaldi - Trio Sonata in d minor opus 1 No. 12 RV63 La Follia (1705), tema.

\footnotetext{
${ }^{39}$ Pseudônimo de Johann Heinrich von Weissenburg.
} 


\subsection{Sarabande de Haendel: Folias de Espanha?}

O famoso tema Folias de Espanha foi transformado em dança de corte e depois retomado por compositores de todos os estilos nacionais importantes da música barroca européia, tais como Corelli (representante do expansivo estilo italiano) e Haendel (les goûts réunis). A escolha para uma análise retórico-musical da Sarabande da Suíte para Cravo N.11 em Ré menor (1727) de George Frideric Haendel (1685-1759) pretende comparar e demonstrar aspectos retóricos que a ligam à ária para oboés de Lully e que, mais tarde, se desdobrarão na história futura da Folias de Espanha. Outras peças contemporâneas e de autores de outros países possuem algum tipo de relação mais estreita ou mais distante com esse tema, juntamente com a versão de Corelli.

A Suíte N. $11^{40}$ foi provavelmente composta entre 1703 e 1706, de acordo com a edição de um manuscrito por Chrysander, no século XIX ${ }^{41}$. Existia uma confusão sobre a autenticidade das diversas edições das suítes de Haendel, devido às publicações nãoautorizadas: de acordo com Ken Whitcomb ${ }^{42}$, o compositor encarregou o editor John Cluer, em 1720, de publicar o primeiro volume das Suites de Pièces pour le Clavecin. Para confundir as edições apócrifas, Haendel revisou as suítes e encorajou seu público a adquirir apenas as versões autorizadas, sendo que o segundo volume saiu pela edição de John Walsh, com a permissão do compositor.

Em primeiro lugar, destacamos o acessível nível técnico da Suíte $\mathrm{N}^{\circ} 11$. O cravista Temple Painter escreveu que Haendel se inspirou na música do passado ao compor essa suíte, deixando de lado seu famigerado brilhantismo técnico ao teclado para fazer o

\footnotetext{
${ }^{40}$ Vol.II, N.4, HWV 437.

${ }^{41}$ VIGNAL, apud GABLER, 2008.

${ }^{42}$ WHITCOMB apud id., ibid.
} 
instrumento soar como se fosse um delicado alaúde ${ }^{43}$. A propósito dessa analogia, observamos que o repertório violonístico conta com excelentes transcrições da Sarabande de Haendel, resultando muito bem no tom original de Ré menor. Painter descreve ainda o caráter dos demais movimentos: uma ondulante allemande e uma divertida courante servem de prelúdios a uma extraordinária sarabande, fechando com um toque de humor na gigue. Empreenderemos, em seguida, uma análise das características retórico-musicais contidas na Sarabande de Haendel.

No nível geral, sua inventio foi extraída de um locus testimoniorum, cujo citatum (citação de Lully) está implícita aos conhecedores do tema - que, na época, vale lembrar, gozava de grande popularidade. Seu tom é Ré menor, associado, conforme verificamos na época de Haendel, ao afeto da melancolia, em andamento grave, assim como seu caráter geral. Sua rítmica pontuada aponta para um afeto de coloração fúnebre, e está associada a uma figuração melódica que utiliza a anabasis (desenhos ascendentes) combinada ao gradatio (nas progressões) e ao suspiratio (nas pausas dos terceiros tempos).

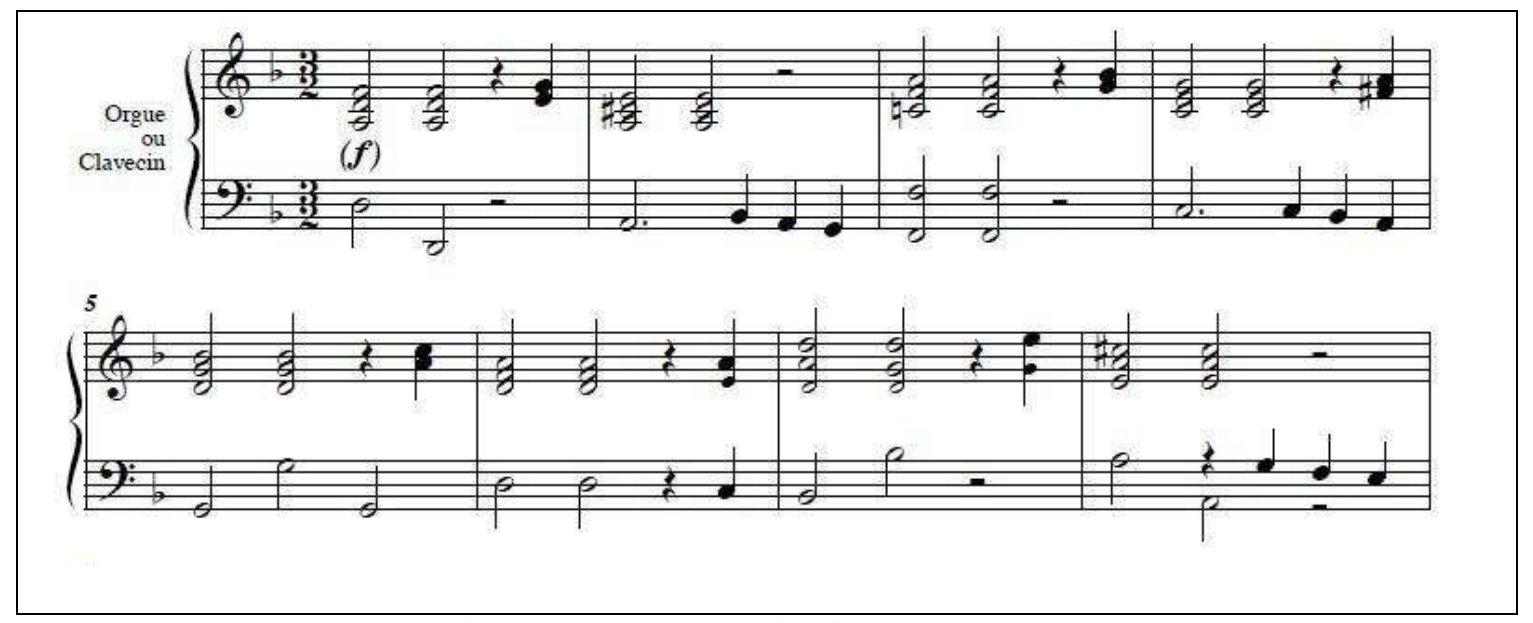

Fig.2.10: Haendel: Sarabande (1727), tema.

\footnotetext{
${ }^{43}$ PAINTER, apud GABLER, ibid.
} 
Seus intervalos-chave são a terça menor descendente (nas finalizações das semifrases) e a quarta ascendente (nas retomadas de frase), que podem representar tanto resignação (terças descendentes) quanto coragem (quartas ascendentes). A sarabande é uma dança tradicionalmente cortesã, coreografada com acentuada pomposidade.

A dispositio ${ }^{44}$ é o tema com (duas) variações, sendo que o sujeito principal já constitui uma variação harmônica da Folias de Espanha, exposto na forma retórica exabrupto, ou seja, sem introdução,. O fato de essa obra conter duas variações, assim como a ária de Lully, pode ser significativo: o número 2, dentro da tradição retórica luterana - na qual Haendel teve sua formação - significava a dualidade homem/mulher. Cada variação poderia ser representada por um pólo desta divisão: enquanto que a primeira variação caminha pela tessitura de vozes femininas a duas vozes distribuídas contrapontisticamente entre soprano e contralto, em disposição vertical,

\footnotetext{
${ }^{44}$ A dispositio consistia na maneira de organizar o discurso, baseada na estrutura do discurso de Quintiliano. Vale lembrar que as formas musicais barrocas e, sobretudo, clássicas são decorrentes desse tipo de organização do discurso proveniente da arte retórica. Na disposição, ou estrutura - em retórica adota-se o termo estrutura no lugar de forma pois este último é um conceito platônico e implica em uma fôrma ontologicamente pré-existente, o que não é o caso da dispositio - o autor pode seguir dois caminhos: a sequência natural (ordo naturalis), baseada nos ciclos da natureza: nascimento, crescimento e morte; ou o estilo fantástico (ordo artificialis), como uma desproporção intencional, cujo objetivo não é ser coerente com a natureza, mas com a finalidade proposta - em música, o gênero fantasia. Neste último estilo, conta-se com o discernimento do ouvinte para corrigir a aparente desproporção.
} 


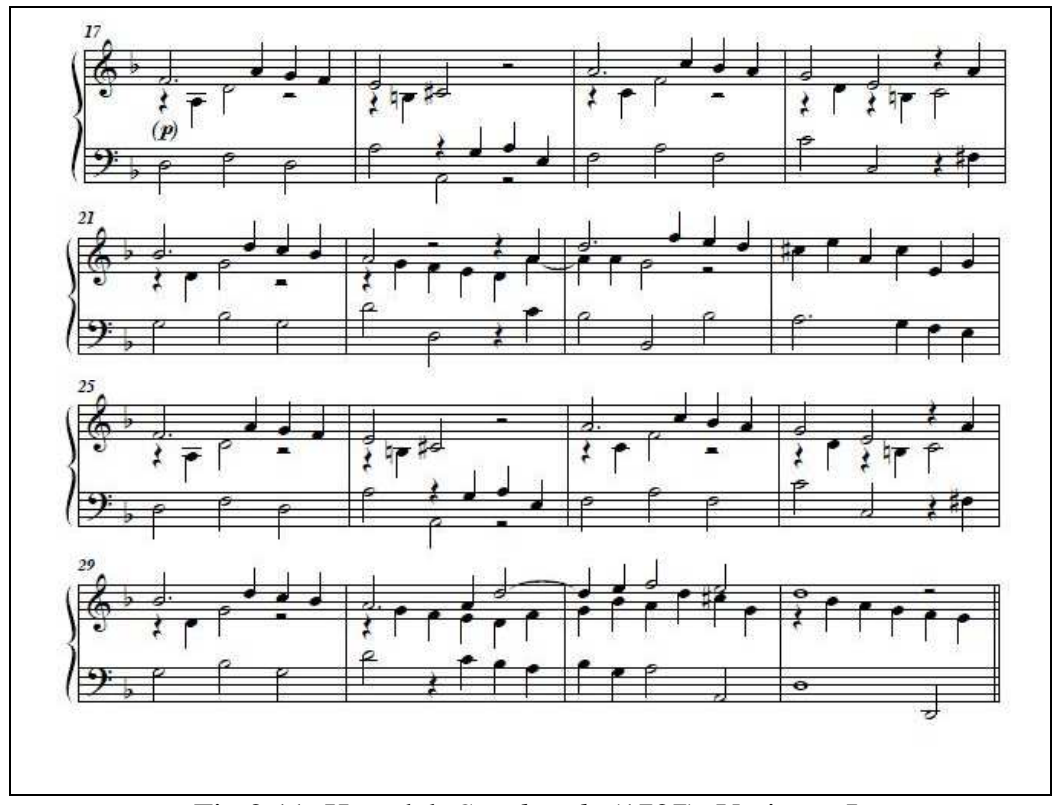

Fig.2.11: Haendel: Sarabande (1727), Variação I.

a segunda variação explora as tessituras masculinas, iniciando-se no registro do tenor na primeira frase, passando, no compasso 41, ao do barítono, em disposição horizontal:

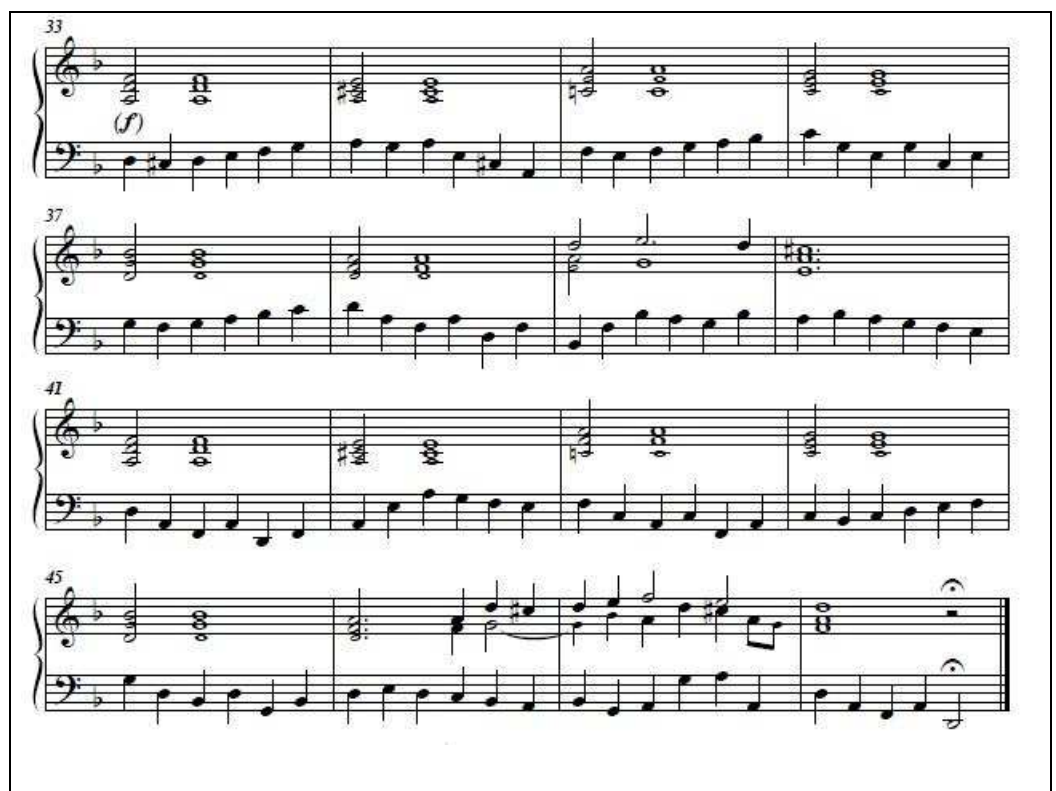

Fig.2.12: Haendel: Sarabande (1727), Variação II. 
Observando a estreita conexão das variações em Haendel com o modelo de Lully, percebemos que o compositor alemão inspirou-se tanto no aspecto formal quanto de textura - duas variações, sendo que a primeira explora a região aguda e a segunda, a grave:

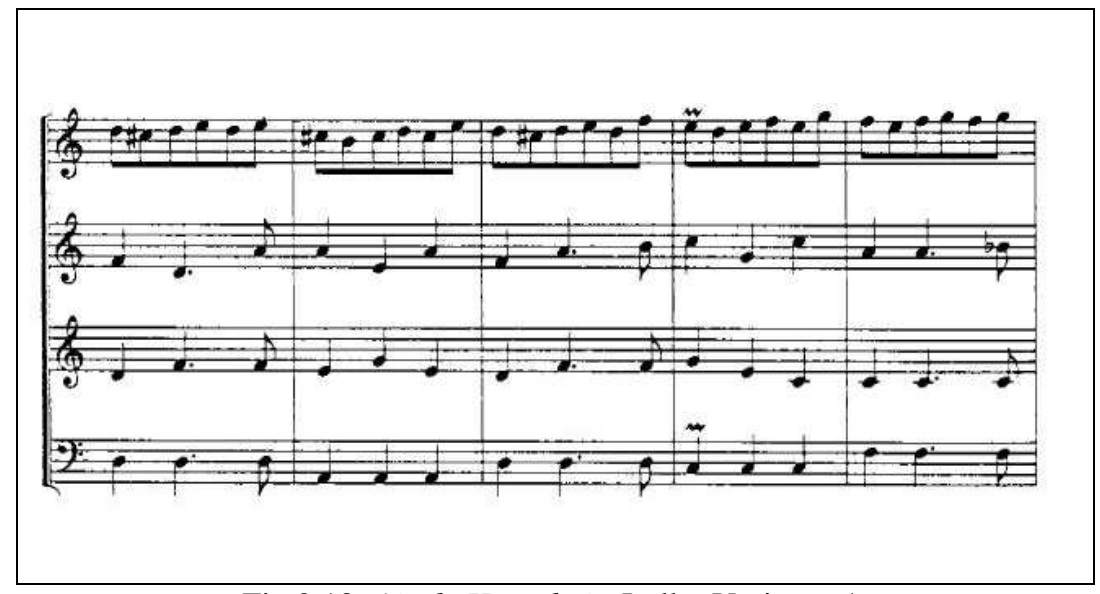

Fig.2.13: Air de Hautobois, Lully, Variação 1.

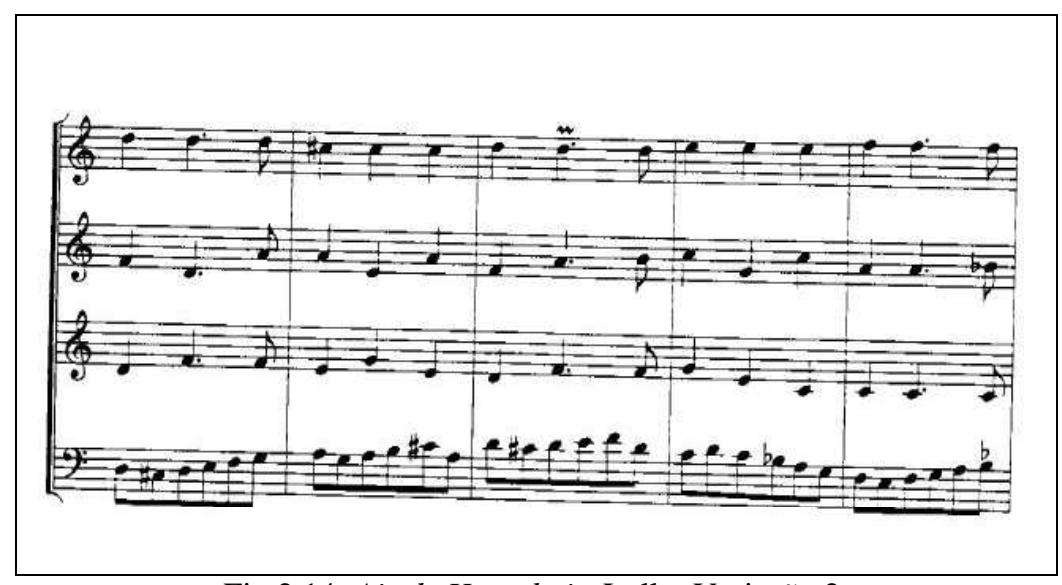

Fig.2.14: Air de Hautobois, Lully, Variação 2.

Somando-se as variações com o tema, temos o número 3 , indicativo da trindade e da perfeição divina - lembrando que o tema está exposto em escrita homofônica coral. Essa disposição é aparentemente artificial e poderia tender ao gênero fantástico, pois foge do 
padrão retórico-musical tradicional da dispositio ${ }^{45}$, mas o equilíbrio no jogo das vozes das duas variações parecem trazer a sensação de que se trata de uma ordem de caráter não apenas natural, mas transcendente. O ouvinte fica com uma agradável sensação de que "não poderia ser de outra maneira".

Sua elocutio $^{46}$ denota a invocação da tradição do passado em forma de locus circumstantiarum (tributo) pela escrita em estilo polifônico. A ausência de ornamentações e a escrita emulando um estilo vocal/coral afirmam o tom de gravidade e seriedade transcendente que a peça invoca. O estilo é temperado, pois reúne tanto extraordinárias agudezas em seu engenho composicional (conforme constatamos na inventio) quanto a objetividade da escrita a quatro vozes, e provavelmente foi destinada a aprazer seu público (possivelmente destinado aos cravistas de nível amador). Suas qualidades de elocução são todas muito bem resolvidas: pureza de linguagem (sobretudo na harmonização) e clareza (contém inquestionável eloqüência); seu decoro é de sentimento profundo, mas sem pedantismos: pode ser usufruída tanto por um expert quanto por um ouvinte comum; sua elegância reside na sobriedade e economia no uso das figuras e da ornamentação.

\footnotetext{
${ }^{45}$ Exordium, narratio, confutatio, confirmatio, peroratio.

${ }^{46}$ A elocutio tratava da escrita em si: enquanto a inventio busca o material (res), a elocutio busca a palavra (verba) ou o som, em música. É a arte da composição e do estilo, ou seja, a adequação dos elementos da proporção res/verba em função do decoro do orador, do tempo, da circunstância, etc., na qual evidenciam-se os procedimentos que atribuem ênfase e força no decorrer da composição. As qualidades/virtudes do orador também foram observadas pelos compositores: correção (puritas), clareza (perspicuitas), adequação (decorum) e elegância (elegantia). Enquanto a correção e clareza correspondiam ao domínio da gramática e da eloqüência, o decorum tratava da escolha apropriada dos estilos e gêneros musicais de acordo com a ocasião da execução: por exemplo, se a ocasião era solene, convinha utilizar o estilo alto - música sacra ou qualquer ocasião que requeria dignidade - se o público era misto ou se a ocasião exigia o deleite, o estilo médio era mais adequado devido ao uso de afetos medianos - música instrumental utilizada, por exemplo, nas conversas de salão ou na Taffelmusik, em que o público era misto - enquanto que para as platéias mais vulgares, se a matéria era chã ou visava o ensinamento, o estilo mais apropriado era o baixo (canções). A elegância consistia no uso de figuras de estilo, cujo objetivo era maravilhar e causar estranhamento. Em música, o emprego de figuras musicais era confiado aos recursos melódicos, intervalares, rítmicos, harmônicos, ou mesmo suas combinações, que se destacam por potencializar o afeto geral da obra.
} 
A actio $^{47}$ desta peça requer um cuidado especial em relação ao toque cantabile num instrumento cuja articulação é seca, como o cravo. Existe uma margem para embelezamentos e improvisações pelas indicações de ritornello em cada uma das três partes da obra, mas o critério adotado pelo executante deverá se adequar ao espírito elevado e melancólico que a peça ostenta, levando sempre em consideração a característica vocal da composição $^{48}$.

Uma das maiores dúvidas em relação à Sarabande de Haendel reside no fato dela ser, efetivamente, o próprio tema da Folias de Espanha de tradição lullyiana. Para o pesquisador Paul Gabler:

Esta melodia, com o mesmo tipo de moldura e idéia da Folia, é freqüentemente chamada de Folia de Händel. Todos podem ouvir que ele não é Folia mas desde que Händel não escreveu quaisquer Folias e essa peça respira da mesma atmosfera, e muito provavelmente Händel tinha o tema da Folia em mente quando escreveu esta Sarabande, ela se tornou conhecida como a 'Folia de Händel' da mesma forma que o equívoco generalizado de que o 'Take Five' foi escrito por Dave Brubeck, porque seu quarteto sempre tocava a peça. As semelhanças entre o tema Folia e a Sarabande de Händel são marcantes de qualquer maneira: tema e variações de mais de 16 compassos com duas frases regulares de oito compassos, ritmicamente o valor pontuado no segundo tempo de cada compasso e o mesmo tipo de condução nos registros graves e agudos. (GABLER, 2008, tradução nossa). ${ }^{49}$

\footnotetext{
47 A actio abrangia as habilidades teatrais do orador: pronúncia (ortopéia e paralinguística), prosódia (entonação, ritmo, intensidade, pausas), gestualidade (corpo, mãos, quironomia [gestos retóricos decodificados] e quirologia [movimentos naturais das mãos, face]), proxêmica (relação do corpo em um determinado espaço), preparação física e psicológica. Esse conjunto de habilidades correspondia à tarefa do orador que proferia os discursos elaborados por ele próprio ou por um logógrafo, ou do intérprete em música. É bom lembrar que a maioria dos músicos das eras barroca e clássica era, simultaneamente, compositor e executante. No caso dos cantores, a questão de actio mais debatida entre os teóricos era: qual tipo de cantor mais apropriado numa representação musical? Um cantor-ator ou um ator-cantor? Na actio, um dos recursos mais importantes era o apropriado uso do pathos, ou seja, a emoção ou paixão que o intérprete se valia a fim de atribuir verossimilhança ao afeto do discurso, tanto na oratória quanto na performance musical.

${ }^{48} \mathrm{O}$ estilo elevado permitiria então grande profusão de ornamentos, o que não é o caso desta peça.

${ }^{49}$ No original: "This tune with the same sort of framework and idea as the Folia is often called Händel's Folia. Everybody can hear that it is no Folia but since Händel did not write any Folias at all and this piece breaths the same atmosphere, and most likely Händel had the Folia-theme in mind when composing this Sarabande, it became known as 'Händel's Folia' in much the same way as the widespread misunderstanding that 'Take Five' was written by Dave Brubeck because his quartet always played the piece. The similarities between the Foliatheme and the Sarabande by Händel are striking in any way: theme and variations over 16 bars with two regular eight measure phrases, rhythmically the dotted value on the second beat of each measure and the same sort of voicing in upper and lower register."
} 
O principal argumento dos estudiosos da Folias de Espanha ao negar o uso do tema é que a sarabanda de Haendel não usa o esquema harmônico típico, em forma de palíndromo. De fato, é forçoso admitir que o aspecto circular arcaico do tema ibérico favoreceu o aspecto evolutivo de uma harmonia em progresso na versão haendeliana. No entanto, uma rápida análise comparativa entre as harmonias da Folias de Espanha e da Sarabande indica diferenças muito sutis: do ponto de vista da análise tradicional (por classificação em graus) elas diferem consideravelmente, porém suas funções harmônicas principais são bastante semelhantes:

\begin{tabular}{|c|c|c|}
\hline C. & $\begin{array}{c}\text { Folias de Espanha } \\
\text { (arquétipo): }\end{array}$ & $\begin{array}{l}\text { Sarabande } \\
\text { (Haendel) }\end{array}$ \\
\hline 1 & $\mathrm{Dm}$ & $\mathrm{Dm}$ \\
\hline 2 & A7 & A7 \\
\hline 3 & Dm & $\mathbf{F}$ \\
\hline 4 & $\mathrm{C}$ & $\mathrm{C}$ \\
\hline 5 & $\mathbf{F}$ & Gm \\
\hline 6 & $\mathbf{C}$ & Dm \\
\hline 7 & Dm & Gm \\
\hline 8 & A7 & A7 \\
\hline 9 & $\mathrm{Dm}$ & $\mathrm{Dm}$ \\
\hline 10 & A7 & A7 \\
\hline 11 & Dm & $\mathbf{F}$ \\
\hline 12 & $\mathrm{C}$ & $\mathrm{C}$ \\
\hline 13 & $\mathbf{F}$ & Gm \\
\hline 14 & $\mathbf{C}$ & Dm \\
\hline 15 & Dm/A - A7 & Gm - Dm - A7 \\
\hline 16 & $\mathrm{Dm}$ & $\mathrm{Dm}$ \\
\hline
\end{tabular}


Tabela 2.2: Análise harmônica comparativa entre Folias de Espanha e Sarabande de Haendel.

Nos compassos 3 e 11, temos a função de Tônica substituída pelo acorde relativo tríade maior de Fá. Nos compassos 5-6 e 12-13 há uma diferença cadencial, em que a resolução Dominante-Tônica é substituída pela cadência deceptiva: DominanteSubdominante Relativa, ou V-ii. O compasso 6, com o retorno à Tônica, é o que mais se distancia em relação ao tema original, que está na função de Dominante da Relativa Maior, mas a retomada ao segundo grau da relativa maior - tríade menor de Sol - faz o tema voltar a sua identidade original.

Outro aspecto relevante é que o perfil melódico, em vista da nova harmonização, teve seu alcance ampliado, chegando a uma $8^{\mathrm{a}} \mathrm{em}$ sua tessitura - em contraste à amplitude limitada da Folias de Espanha, que compreende apenas uma $3^{\mathrm{a}}$ maior $^{50}$.

Poderíamos aqui adotar o critério de análise de Arnold Schoenberg (1874-1951), sem o perigo de utilizar erroneamente uma chave de análise de dois séculos à frente, no que tange à mudança harmônica efetuada por Haendel nesta sarabanda. O compositor e teórico austríaco sustenta que a forma Tema e Variações pressupõe a modificação de um dos elementos e a conservação dos demais ${ }^{51}$. Portanto, uma vez que o perfil rítmico e estrutural se mantêm preservados, a melodia e harmonia são meramente elementos de variação na Sarabande de Haendel.

A fim de arrematarmos a questão, citamos um bem-humorado veredicto de Richard Yates:

Portanto, à parte desta análise teórica [do autor citado, não a que acabamos de apresentar], o que você acha? A 'Sarabande' de Händel tem o sentimento da

\footnotetext{
${ }^{50}$ Cf. figuras 1.21 e 2.11 .

51 SCHOENBERG, 1993, p.203. Veremos adiante como a harmonia passou a ser tipificada como um dos recursos-chave de variação.
} 
'folia'? Você ouvirá ecos de uma multidão de outros compositores? Ficará cantarolando para si mesmo pelos próximos quinhentos anos? Então, trata-se de uma folia! (YATES, 2004, p.53, tradução nossa). ${ }^{52}$

Hoje, a Sarabande da Suite $\mathrm{N}^{\mathbf{0}} 11$ de Haendel goza de imensa popularidade, sem precedentes na história, após a utilização de um arranjo orquestral na trilha do filme Barry Lindon, de Stanley Kubrick - que será analisada na parte final deste trabalho, que a partir de 1975 superou a fama da versão de Corelli. O tema tem sido revisitado em diversas ocasiões, utilizada inclusive como vinhetas, desde campanhas publicitárias até documentários televisivos.

\footnotetext{
${ }^{52}$ Richard Yates, G.F. Handel, Sarabande con variazioni, transcribed for guitar. Magazine: Soundboard (the journal of the Guitar Foundation of America), Vol. XXX, No. 2, p. 50-53, published in October 2004, tradução nossa. No original: So, aside from this theoretical analysis, what do you think? Does Händel's 'Sarabande' have that 'folía feel? Will you be hearing echoes of it in a multitude of other compositions? Will you be humming it to yourself for the next five hundred years? Then that's a folia!
} 


\subsection{Bauernkantate de Bach: uma paródia setecentista}

O conceito de paródia, termo de origem grega (parodia), foi estudado extensivamente em diversos contextos e épocas por teóricos como Margaret Rose ${ }^{53}$, e seu aprofundamento neste trabalho será útil para compreendermos o declínio que o tema Folias de Espanha sofreu a partir da segunda metade do século XVIII e seu reaparecimento na segunda metade do século XX.

Colocando de maneira resumida, para em seguida examinar as nuances desse processo em seus casos específicos, a paródia é um procedimento de imitação com intenção de produzir um efeito cômico ${ }^{54}$.

A concepção romântica do termo, que associa a paródia ao burlesco - um termo historicamente mais recente e de conotação negativa - provocou imprecisões que distorcem o entendimento deste recurso no barroco alemão ${ }^{55}$. Outras imprecisões são oriundas da atribuição de equivalência entre a paródia e outros conceitos próximos, tais como a sátira, o pastiche, o plágio, a paráfrase, etc. O crítico literário português Carlos Ceia resume as diferenças entre esses termos tão próximos ${ }^{56}$ :

- Alusão: referência indireta a um texto preexistente;

- Citação: transcrição de um texto preexistente;

- Paráfrase: desenvolvimento de um texto preexistente;

- Paródia: deformação de um texto preexistente;

- Pastiche: imitação criativa de um texto preexistente;

- Plágio: imitação ilegítima de um texto preexistente;

\footnotetext{
${ }^{53}$ Cf. também autores como Frederic Jameson, Linda Hutcheon, etc.

${ }^{54}$ ROSE, 1993, p.59

${ }^{55}$ Id., ibid., p.5.

${ }^{56}$ CEIA, 2009.
} 
- Sátira: censura de um texto preexistente.

Partindo dessas definições iniciais, tomadas da linguagem literária, podemos nos aproximar um pouco mais do significado musical da paródia no barroco, particularmente em seu modo de funcionamento na obra de J. S. Bach (1675-1750), uma vez que encontramos algumas citações paródicas da Folias de Espanha em algumas de suas obras ${ }^{57}$, especialmente na Bauernkantate BWV 212, de 1742.

Bach nunca tomou melodias profanas para compor ciclos de Tema e Variações, mas empregou-as em outros contextos. Nikolaus Harnoncourt, em seu livro O Diálogo dos Sons, esclarece a função da paródia nas cantatas profanas de Bach, afirmando:

Texto e música em Bach estão intimamente inter-relacionados de uma maneira cujas raízes remontam à Itália do início do século XVIII [...]. Esta relação, direta e inaudita, é da maior importância para os músicos. Assim é que não separamos o texto da música, nem procuramos apenas fazer boa música com palavras que, mais ou menos, se adaptam a ela; ao contrário, vemos uma combinação ideal de sons e palavras e uma interpretação ideal que, no caso de Bach, se realiza freqüentemente em vários níveis. Isto significa que o cantor canta o texto, enquanto a orquestra comenta este texto, sem se limitar a meramente acompanhá-lo, mas interpretando e explicando seu conteúdo, no sentido que Bach queria transmitir. A idéia de um sermão está implícita neste tipo de música: sem dúvida um sermão uniforme onde são simultâneas a expressão verbal e a interpretação retórico-musical, em que até o elemento gestual é incorporado ao espírito do antigo drama musical, de uma maneira que seria inconcebível do ponto de vista meramente declamatório. A descoberta desta pluralidade de níveis pressupõe evidentemente uma análise precisa da parte do intérprete. Cada parte instrumental deve portanto receber sua própria configuração retórica, que com frequiência contradiz o texto cantado. Somente a interação do conjunto revela o sentido do texto, habitualmente de caráter moral e pedagógico. (HARNONCOURT, 1993, p.76).

Vemos, portanto, que a paródia, no contexto do repertório bachiano, não possuía conotações satíricas ou cômicas conforme o conceito básico acima aludido, mas funcionava como um procedimento usual adotado por vários compositores barrocos. Na prática, é até mesmo impossível determinar a diferença estilística entre as cantatas profanas e sacras de Bach, pois a música secular só era inapropriada na igreja quando o texto da canção continha

\footnotetext{
${ }^{57}$ Cf. também a obra Concerto em Ré menor sobre Johann Ernst von Sacksen BWV 987 (ca. 1708-1717).
} 
associações não religiosas ${ }^{58}$. Para ele, não havia algo como música puramente religiosa ou profana, pois em sua concepção, proveniente daquela do próprio Lutero, toda música glorifica Deus ${ }^{59}$. Bach costumava registrar, inclusive, o famoso anagrama SDG (soli deo gloria) em muitas de suas obras não religiosas ${ }^{60}$.

Esse entendimento era compartilhado com os fiéis da época, que sabiam muito bem que a diferença entre o sacro e o profano na música residia na finalidade da composição e no conteúdo poético da mesma, de modo que ninguém censurava as cantatas profanas de Bach posteriormente transformadas em sacras durante o período de Leipzig, entre 1723 e 1750. A divisão estrita e irreversível entre música sacra e profana é uma visão proveniente não apenas da tradição católica, mas também iluminista:

\begin{abstract}
Foi somente com estética posterior a Bach que o conceito de paródia aparece de forma desfavorável. À medida em que a música se tornou uma arte mais autônoma e uma atividade cada vez menos dentro de certas estruturas sociais, o compositor lutava para encontrar uma voz individual; gênio e originalidade tornaram-se conceitos virtualmente sinônimos. Na época de Bach, entretanto, um certo grau de paródia era quase inevitável, uma vez que a música tinha de ser provida regularmente para ocasiões específicas na igreja, na corte e no teatro. (BUTT, 1991, p.42, tradução nossa). ${ }^{61}$
\end{abstract}

O legado remanescente do conceito romântico de "gênio criador" e "obra original" ainda permanece no imaginário do público hodierno, razão pela qual o pastiche adquiriu uma conotação negativa em nossos dias, normalmente associada a uma aparente falta de criatividade do compositor. É preciso lembrar que os compositores do Barroco:

\footnotetext{
${ }^{58}$ WESTRUP, 1969, p.17.

${ }^{59}$ SWARTZ, 2009.

${ }^{60}$ Id., 1998.

${ }^{61}$ No original: "Only with a musical aesthetic later than Bach's does the concept of parody [...] appear in a unfavourable light. As music became more an authonomous art and less an established craft within certain social structures, the composer strove to find an individual voice; genious and originality were virtually synonymous concepts. In Bach's time, however, a certain degree of parody was almos unavoidable, since music had to be provided so regularly for specific ocasions in church, court and theatre."
} 
[...] não eram gênios torturados despejando suas almas nas Escrituras da Criatividade; eles eram profissionais contratados para entregar música sob demanda. Eles se assemelhavam mais aos compositores de trilha de cinema dos tempos atuais do que aos compositores ditos 'sérios'. [...] Além disso, muitas das obras originais encomendadas seriam tocadas apenas uma vez e nunca mais ouvidas novamente; frequentemente, os compositores parodiavam para terem mais tempo livre fora da boa música. Enquanto os grupos musicais podem hoje gravar uma canção e reproduzi-la repetidamente, os compositores barrocos só podiam ouvir suas músicas ao vivo: a paródia, nesse contexto, não é pior do que ouvir a mesma canção repetida no rádio - pelo menos, com a paródia, algo é diferente na segunda vez! (SWARTZ, 1998, tradução nossa) ${ }^{62}$.

A relação música e texto já estava na berlinda das discussões entre os músicos há vários séculos, porém a paródia entra em cena como um novo elemento a ser considerado a partir do início do luteranismo, sendo que em Bach este procedimento torna-se mais contundente. Se considerarmos que o aspecto sistemático da retórica na música era ainda presente na música alemã do século XVIII, sobretudo na de Bach, entendemos a importância de sua função discursiva, em que a expressão musical deveria sempre estar associada à expressão poética e afetiva.

Bach considerava esse vínculo um elemento essencial em sua obra justamente pelo fato de ser um intérprete convicto da tradição luterana, porém essa questão é polêmica, uma vez que alguns o viam como um simples mestre de capela, que não estava preocupado com suas implicações religiosas ou confessionais. Harnoncourt cita um exemplo da famosa dedicatória da Missa em Si menor ao rei católico da Saxônia Frederico Augusto II, na qual ele se oferece como um compositor de todo tipo de música sacra e profana ${ }^{63}$. Este ponto da biografia de Bach nos interessa particularmente, pois sua produção de cantatas sacras

\footnotetext{
${ }^{62}$ No original: "Baroque composers were not tortured geniuses pouring their souls into great Creative Statements; they were hired hands, expected to deliver music on demand. They resembled present-day movie score composers more than 'serious' composers. [...] Furthermore, many of the original, commissioned works would be played once and never heard again; often, composers would parody these occasional works to get more play time out of good music. While today's music groups can record a song and play the recording over and over again, Baroque composers would only hear their music live: parody, in this context, is no worse than playing a song over and over again on the radio-at least with parody, something is different the second time!"

${ }^{63}$ HARNONCOURT, 1993, p.77.
} 
começa a diminuir a partir de 1729, após ter assumido a direção da sociedade musical Collegium Musicum de Leipzig.

Dessa época em diante, o compositor começa a compor e adaptar cada vez mais música profana, não por falta de interesse ou por ter simplesmente dominado o gênero sacro, mas devido ao seu requerimento por um título, cujo processo iniciou-se a partir de 1733 com a morte de Frederico I, antecessor do referido rei católico. Em menos de dois meses após ter submetido as partituras da Missa em Si menor, Bach iniciou uma produção intensa de cantatas profanas lisonjeadoras em homenagem ao novo Eleitor e seus familiares. Essas cantatas profanas faziam parte da tentativa do compositor em obter o título, que foi a ele concedido em 1736, com sua nomeação como compositor da corte de Dresden $^{64}$.

Das 200 cantatas de Bach que restaram e conhecemos hoje, 170 foram escritas para a igreja e as restantes estão relacionadas a temáticas de celebração, tais como casamentos, funerais, celebrações da nobreza ou líderes de cidades. A estrutura dessas cantatas profanas é idêntica à das sacras, exceto pela ausência dos corais luteranos, e estão divididas em três tipos:

- Cantatas de homenagem a pessoas importantes (ex.: BWV 214, para a realeza);

- Cantatas para ocasiões especiais (ex.: BWV 210, para uma cerimônia nupcial);

- Cantatas de entretenimento (ex.: BWV 201, em homenagem ao café) ${ }^{65}$.

A Bauernkantate, ou Cantata Camponesa (1742) costuma ser apresentada junto com a Cantata do Café (1734), pois ambas foram escritas sobre textos de Picander $^{66}$ e

\footnotetext{
${ }^{64}$ SWARTZ, 2009, p.7.

${ }^{65}$ Id., 1998.

${ }^{66}$ Pseudônimo do poeta alemão Christian Friedrich Henrici (1700-1764), com quem Bach estabeleceu uma produtiva parceria que inclui diversas cantatas sacras e profanas, além das Paixões de Marcos e Mateus.
} 
possuem temáticas humorísticas - uma faceta pouco conhecida de Bach - e levemente críticas. Enquanto o roteiro geral desta última trata das maneiras e costumes dos concidadãos de Leipzig, a primeira descreve os jogos amorosos de um casal camponês (baixo e soprano), cujos diálogos descrevem sua atração recíproca, suas preferências por bebidas e elogios à posse do novo senhor do domínio feudal de Kleinzchocher, nas proximidades de Leipzig.

No fundo, é também um retrato burlesco dos camponeses da Saxônia, já que o texto foi escrito no dialeto saxônico. A idéia para esta cantata veio de Picander, sendo ele próprio um oficial do governo em Leipzig, responsável pela coleta das impostos na região e, portanto, subordinado ao novo soberano ${ }^{67}$. A estréia da obra aconteceu no dia da posse do novo senhor do condado, Carl Heinrich von Dieskau, em 30 de agosto de 1742 no Solar de Klein-Zschocher, perto de Leipzig.

A atmosfera burlesca que Bach utilizou para Mer hahn en neue Oberkeet procura ressaltar a oposição entre a cidade e o campo, como é possível constatar logo na ouverture, uma eloquente paródia de uma pequena orquestra camponesa, tanto na instrumentação violino, viola e contínuo - quanto no estilo - um poutporrit de danças populares:

${ }^{67}$ CROUCH, 1999. 


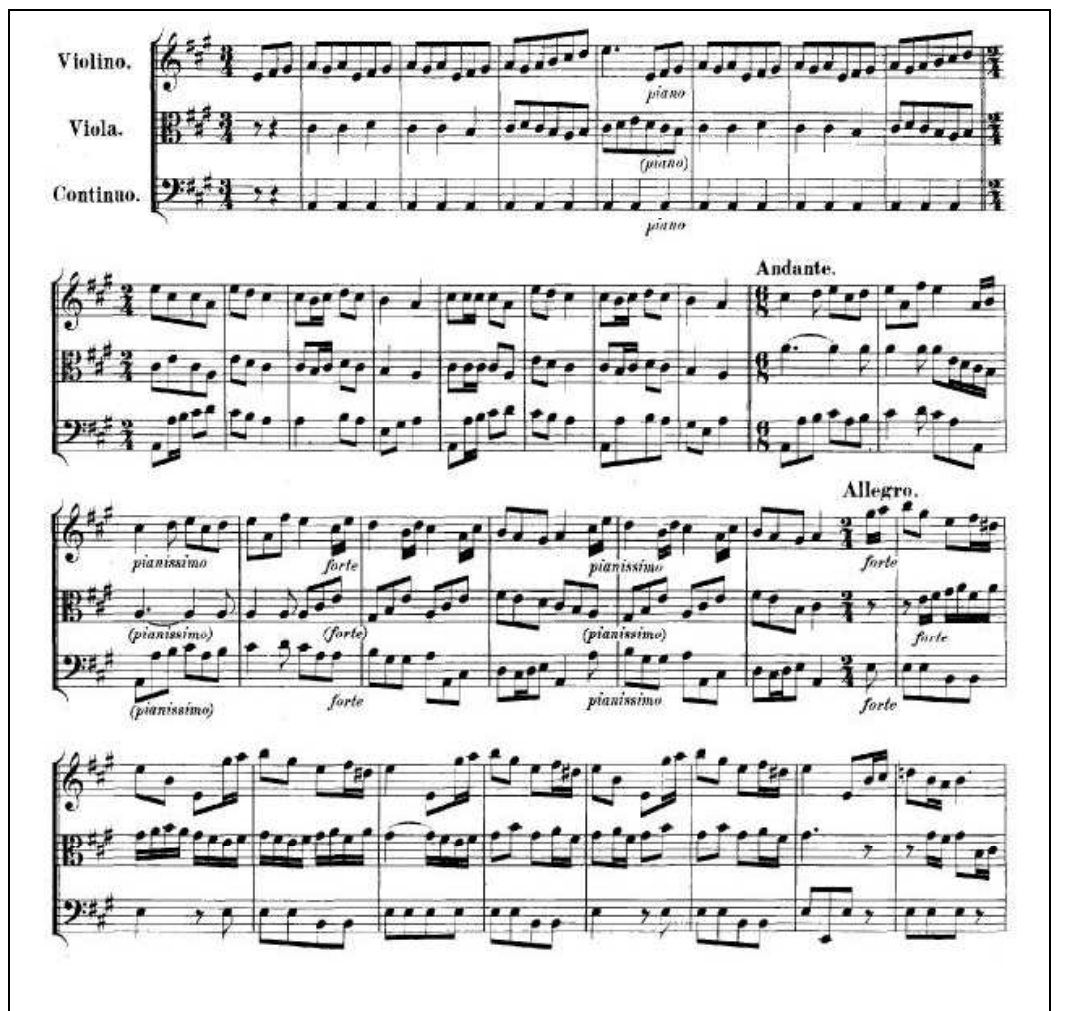

Fig.2.15: Bach: ouverture da Cantata BWV 212

Albert Schweizter reconhece nesta abertura pelo menos três melodias folclóricas: Frisch auf zum frohliches Jagen, uma famosa cantiga de ninar alemã, e uma terceira que reaparece nas Variações Goldberg ${ }^{68}$ :

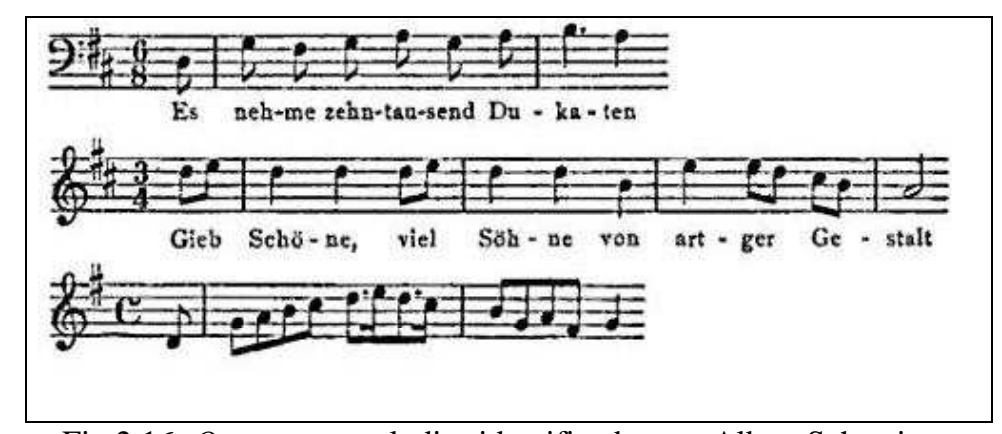

Fig.2.16: Ouverture: melodias identificadas por Albert Schweizter

\footnotetext{
${ }^{68}$ SCHWEIZTER, 2008, p. 290.
} 
A obra é toda concebida em forma de paródia, e sua estratégia retórica consiste em soar propositalmente trivial: os ouvintes familiarizados com a sofisticada escrita contrapontística bachiana são capazes de reconhecer a maneira com a qual o compositor emula o estilo baixo, por meio do uso de bordões, frases de quatro compassos, gestos de dança rígidos, rudezas rítmicas, melodias e encadeamentos harmônicos repetitivos, contraponto de qualidade primitiva. Em apenas 87 compassos da ouverture existem seis mudanças de métrica e cinco de tempo, demonstrando logo de início que a cantata poderia ser de outro compositor, como se tivesse sido realmente inventada por um camponês.

Bach recorreu às melodias populares de sua época, pois nos 23 movimentos que se seguem, encontramos alusões musicais a diversos gêneros de danças e canções que remetem tanto aos ambientes rústicos quanto às danças refinadas da sociedade burguesa: bourrée, sarabanda, minueto, polonesa, mazurca e passepied. Cada solista interpreta uma ária refinada, estilizada à maneira urbana, ao lado dos cantos folclóricos ${ }^{69}$.

As personagens Miecke e seu companheiro, sem nome, são um casal que estão em uma conquista amorosa, sendo que o papel masculino assume a forma de um aldeão que está mais interessado em satisfazer seus instintos básicos, enquanto a mulher procura assumir um ar de sofisticação pretensiosa ${ }^{70}$.

Bach é particularmente mordaz nos números de soprano, como no N.14, KleinZschocher müsse so zart und süsse, que é uma aria da capo em estilo galante com todos seus recursos típicos: uma longa introdução orquestral, interlúdio, uma parte de flauta ricamente ornamentada, tercinas elegantes, embora a parte vocal seja monótona e previsível. No final desta ária há um recitativo ("isso foi muito chique, do jeito que se faz

\footnotetext{
${ }^{69}$ REYES, 2007.

${ }^{70} \mathrm{O}$ texto na íntegra, e sua tradução para o português, encontra-se no DVD anexo.
} 
na cidade") em que o baixo se queixa da música sofisticada e propõe uma boa música camponesa, que por sua vez é considerada grosseira pela soprano ("isso soa muito caipira, temos gente fina por aqui”), convencendo o parceiro a adotar ares mais civilizados ("eu tenho que me esforçar para cantar alguma coisa do tipo que cantam na cidade”).

A ária N.8, Unser trefflicher lieber Kammerherr, para soprano, é a que nos interessa por utilizar o tema Folias de Espanha, verbatim, na tonalidade de Si menor:

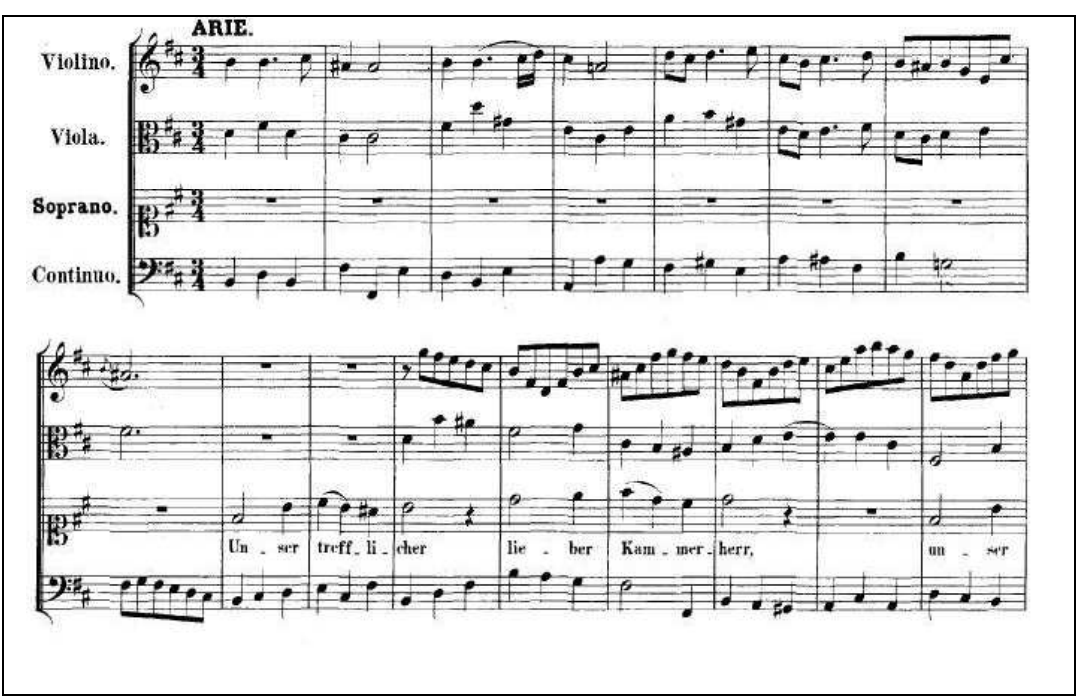

Fig.2.17: Início da ária Unser trefflicher lieber Kammerherr, para soprano.

Esta ária é, de fato, estruturalmente marcante por duas razões: é a primeira virada à tonalidade menor na cantata, bem como a primeira referência claramente "erudita" que aparece até então.

Em contraste com o ambiente geral da cantata, esse número é uma obra prima de ambigüidade musical e textual ${ }^{71}$. A própria tonalidade de Si menor, escolhida por Bach substituindo o tradicional Ré menor, possuía qualidades afetivas ambíguas: se para

\footnotetext{
${ }^{71}$ MENGOZZI, 2003, p.10.
} 
Mattheson (1713) ela era "bizarra e morosa", para Rameau (1722) a representava a "doçura e ternura"72.

Após a chamada para as festividades do dueto inicial ("músicos, fiquem prontos logo!”), a segunda ária da soprano com alusões sexuais ordinárias (“dá uma coceira na barriga, como se pulgas e moscas, e um enxame de vespas estivessem brigando“), e a fria referência do avarento coletor de impostos da terceira ("ah, senhor coletor de impostos, não seja tão mau“), esta ária focaliza a atenção sobre a figura do novo soberano:

\author{
Unser trefflicher, Lieber Kammerherr \\ Nosso excelente, querido governador \\ Ist ein kumpabler Mann, Den niemand tadeln kann. \\ É um homem agradável que ninguém pode censurar.
}

Nikolaus Harnoncourt lembra que:

\begin{abstract}
No período barroco, a noção de Deus estava intimamente ligada ao respeito pelo soberano, o que levava a uma concepção hierárquica em que a identificação simbólica das duas figuras não tinha a conotação de uma blasfêmia. Deus era por definição o soberano supremo e a distância entre o rei, ou seus prepostos, e os mortais comuns era tão grande que o hiato entre príncipe e burguês era considerado intransponível. A partir da época do Barroco, a realeza vivia em palácios suntuosos, semelhantes às igrejas e que nada tinham em comum com as habitações de seus súditos. Por conseguinte, o rei era um ser "superior": na corte de Luís XIV, os fiéis que assistiam à missa deveriam sentar de costas para o altar e de frente para o rei, como se Deus só pudesse ser alcançado pela intervenção do soberano, o demiurgo. (HARNONCOURT, 1993, p.78).
\end{abstract}

Não é o que acontece exatamente nesta ária, que oscila entre o estilo burlesco e laudatório a fim de ressaltar a artificialidade do discurso da soprano. Particularmente durante a segunda estrofe, a música parece comunicar o contrário ao ouvinte, lançando dúvidas em relação às qualidades pessoais e morais do soberano. É como se uma aldeã tentasse, com muito esforço, proferir um discurso elevado que acabasse resultando no efeito contrário, devido às constantes gafes que comete com suas infelizes metáforas ("não se

\footnotetext{
${ }^{72}$ Apud STEBLIN, 1996, p.306.
} 
poderia imaginar um melhor", "nem com um saco de moedas honrá-lo"). A música retrata como seu discurso ordinário trai suas nobres intenções.

É, no mínimo, de se estranhar que exatamente no momento de prestar homenagens ao soberano von Dieskau, a Cantata muda completamente de humor com a adoção do ritmo de sarabanda e uma virada harmônica para um tom menor. E mais ainda: justamente usando o locus testimoniorum Folias de Espanha - que já era um lugar comum trivial por estar em declínio de popularidade e provavelmente representasse algo que o público já estivesse cansado de ouvir - como subtexto, cuja disparidade entre as matrizes verbal e sonora gera um efeito de ácida ironia aos ouvintes mais cultos ${ }^{73}$.

Stefano Mengozzi observa que existem evidências de que a Folias de Espanha não desfrutava de boa reputação na Alemanha em meados do século XVIII, como o relato de Philip Spita sobre o poema "Du strenge Flavia, ist kein Erbarmen da", de Erdmann Neumeister (1671-1756), cantado com a própria melodia Folias de Espanha. De acordo com Spita, o também poeta Johann Friedrich Gräfe (1711-1787) referia-se a este poema, em 1737, como uma coisa miserável que ressaltava o mau gosto dos alemães ${ }^{74}$.

Neste número, que emula o estilo baixo, Bach emprega alguns procedimentos típicos de sua escrita em estilo alto, resultando numa sofisticada paródia da Folias de Espanha: linhas de baixo enriquecidas com acordes em primeira inversão, notas de

\footnotetext{
${ }^{73}$ Utilizamos aqui o conceito de matrizes da linguagem e do pensamento (Sonora, Visual e Verbal) expostos por SANTAELLA (2002), que resumiremos da seguinte maneira: a matriz sonora pode ser classificada em nível de primeiridade, funcionando como eixo de transição entre as matrizes, permitindo o hibridismo entre as linguagens. Essa permeabilidade da matriz sonora favorece que a linguagem musical encaminhe a compreensão dos níveis de primeiridade, quer na visualidade quer no discurso verbal. Um ponto fundamental exposto por Lúcia Santaella parece ser uma das razões da primazia do texto sobre imagem e som como formas de reflexão, a partir de dados culturais: "Quanto mais o simbólico avança dentro da sonoridade e da visualidade, mais estas últimas ficam submissas à lógica do verbal“" (p.375).

${ }^{74}$ MENGOZZI, 2003, p.12.
} 
passagem e cromatismos adicionados à linha melódica, etc. No final da ária a voz central migra para a linha de baixo:

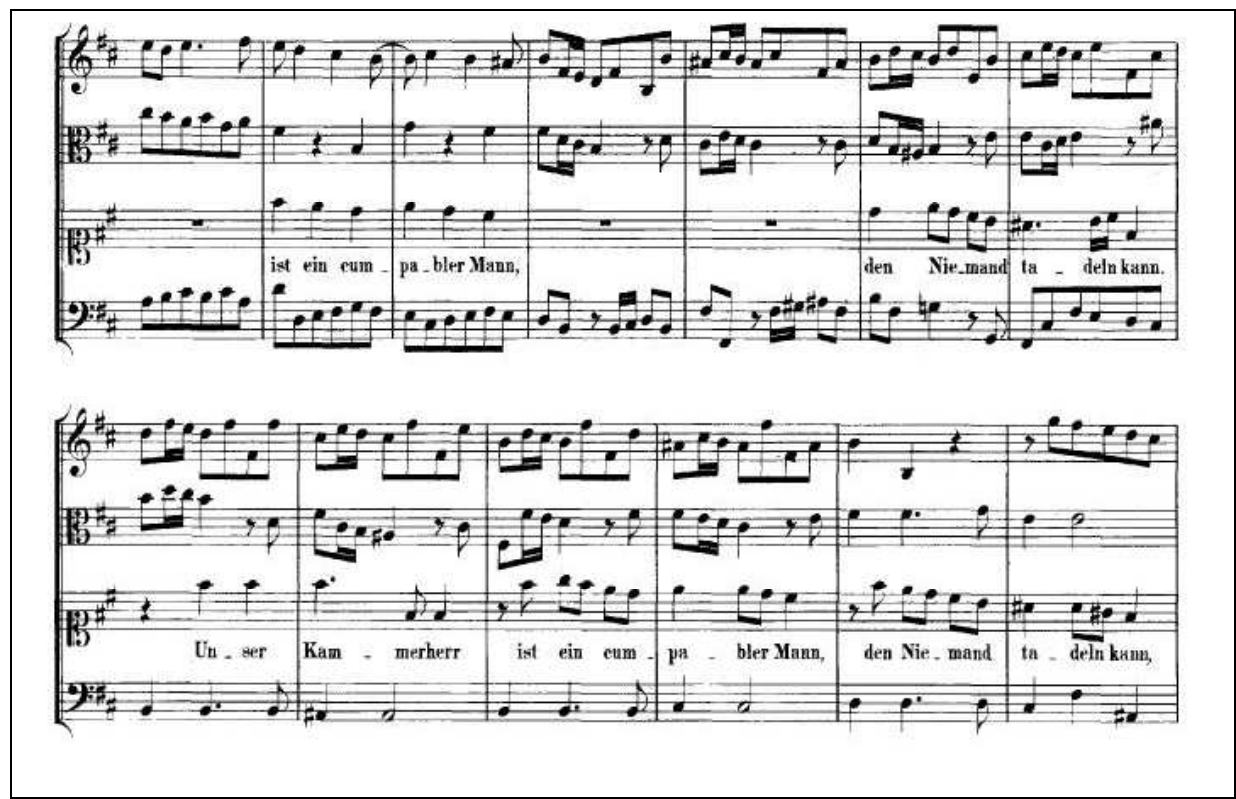

Fig.2.18: Ária Unser trefflicher lieber Kammerherr, compassos 40-52.

A curta passagem instrumental na coda da sustenta-se por uma linha de baixo remanescente de outro lugar comum: a típica passagem descendente da passacaglia (B-A$\mathrm{G}-\mathrm{F} \#)^{75}$.

Martin Geck, ao analisar as características estilísticas da música de Bach do período tardio, afirma que apesar da Bauernkantate possuir pouco em comum com a típica imersão do compositor na expressão pura da linguagem, a obra representa um recorte da totalidade social no âmbito da música. Neste sentido, ela representa uma:

[...] música sobre a própria música, um comentário filosófico-musical para a temática social e ao mesmo tempo um discurso sobre as formas de escrita - como o texto de Picander, que representa uma descrição sobre a vida dos camponeses. Neste sentido, essa despretensiosa composição é uma transição para a "obra tardia": após ela, importa cada vez menos a reflexão sobre a existência da música

\footnotetext{
${ }^{75}$ MENGOZZI, 2003, p.11.
} 
social, e sim a sua essência. Isso é atestado pela Arte Da Fuga, com a qual o compositor já estava intensamente ocupado durante o ano de composição da Bauernkantate. (GECK, 2000, p.473, tradução de Bernhard Fuchs). ${ }^{76}$

O uso do tema Folias de Espanha, dentro do contexto poético da Bauernkantate, foi inteligentemente parodiado por Bach como um recurso retoricamente indecoroso de se prestar uma homenagem a alguém importante através do conflito entre a falta de adequação da linguagem e a tentativa de se alcançar um nível de discurso incompatível com a natureza da personagem camponesa, gerando a ambigüidade de o homenageado ser realmente digno de louvores.

O tom humorístico da cantata completa, sua retórica textual ambígua, assim como a crítica sub-textual de Bach sobre os gêneros musicais urbano e cortesão (ao qual a Folias de Espanha pertencia), contradizem a natureza desta ária como uma homenagem direta e sincera ao novo soberano.

A partir das considerações sobre a cantata profana BWV 212, podemos constatar o alto nível do uso da paródia em Bach: seu proceso é cuidadoso, judicioso e sensível, resultando no enobrecimento do seu material original, cujo resultado equipara-se ao alto nível de sua música original.

A paródia bachiana possui força dramática e musical, costura uma unidade estrutural coesa a partir de fontes desconexas, e resulta numa música nova a partir da adaptação de materiais antigos.

\footnotetext{
${ }^{76}$ No original: "In diesem Sinne ist sie Musik über Musik, musikalisch-philosophischer Kommentar zum Thema Gesellschaft und zugleich ein Diskurs über Schreibarten — wie der Text Picanders einen Diskurs über das Bauernleben darstellt. In diesem Sinne ist die harmlos klingende Komposition überleitung zum "Spätwerk": Danach geht es Bach immer weniger um die Reflexion der gesellschaftlichen Existenz von Musik, immer mehr um ihre Essenz. Dafür steht die Kunst der Fuge, mit der Bach bereits im Jahr der Bauernkantate intensiv beschäftigt ist."
} 
Podemos afirmar que as habilidades retóricas de Bach são suficientemente elaboradas tanto para criar tanto paridades perfeitas quanto para gerar disparidades críticas, dependendo da estratégia retórica do compositor que é revelada pelo equilíbrio entre o conteúdo do texto e a sua intenção de comunicação. 


\subsection{Declínio da Folias de Espanha no Classicismo}

A retórica musical foi praticamente abandonada na segunda metade do século XVIII, com as discussões iluministas sobre os estatutos das artes. Um papel preponderante nesse redirecionamento foi exercido pelo filósofo alemão Alexander Baumgarten (17141762), não apenas pela introdução do termo estética em 1735, como também o classificando como nova ramificação filosófica, ao lado da lógica, metafísica e ética. Baumgarten defendia a premissa de que cada arte tem suas leis próprias ${ }^{77}$. Já os iluministas sustentavam a tese de que a arte resulta de uma atividade simultaneamente intelectual e sensorial, resultando em idéias que podem conter a essência da verdade, não de forma clara, mas como uma imagem desfocada ${ }^{78}$.

A recém fundada teoria filosófica das artes respondia plenamente às necessidades epistemológicas do estatuto das obras, por ajustar-se de maneira mais convincente às metodologias científicas do início do século das luzes. Era tida como ciência que trata do conhecimento sensorial, por meio da qual se chega à apreensão do belo contido nas imagens da arte, em contraposição à lógica, tida como ciência do saber cognitivo. Foi por essa razão que a Estética foi considerada gnosiologia inferior, artifício - por que não dizer retórico? - adotado por tratar de matérias cuja natureza pendia muito mais ao plano da sensibilidade do que da razão.

O pensamento retórico cede, portanto, espaço à concepção subjetiva do belo, associando a obra de arte ao homem. Na verdade, os românticos respeitavam o fascínio da retórica antiga e estavam opondo-se à retórica das figuras, que não apenas reduziu a estrutura retórica à elocução das figuras, mas também alcançou um nível exagerado de

\footnotetext{
${ }^{77}$ BAUMGARTEN, 1735, p.20.

${ }^{78}$ GADAMER, 1997, p.88 et seq.
} 
extravagância nos nomes e nas suas intermináveis classificações. Para os artistas do dezenove, a linguagem era naturalmente figurada e dispensava o artifício das complexas elaborações da retórica das figuras. O belo era tido como característica intrínseca da arte, modelo de perfeição da Natureza que deveria ser imitada (mimesis), de acordo com os parâmetros aristotélicos. A partir de então, a música romântica e, por extensão também a do passado, passou a ser encarada como uma linguagem autônoma, desprovida de significados e afetos, centrada nas figuras do compositor e do intérprete dotados de genialidade transcendental. Assim, a práxis musical iniciaria um caminho sem volta em sua associação interdisciplinar com a retórica, em direção à sua autonomia enquanto linguagem.

A "revolta do espírito" inaugurada pelo movimento filosófico conhecido como Iluminismo abalou as sólidas estruturas em todos os âmbitos da vida social, política e econômica: da autoridade da religião sobrenatural sobreveio a religião natural e a moral; a metafísica foi substituída pelo senso comum, pela psicologia empírica, pela ciência aplicada e pela sociologia; a autoridade foi revogada pela liberdade individual; os privilégios foram derrubados em prol da igualdade de direitos ${ }^{79}$. As novas concepções de mundo introduzidas nas artes por influência do Iluminismo acarretaram mudanças significativas também sobre a produção musical durante o Classicismo.

Dentre as muitas inovações que o século das luzes trouxe para a esfera musical, destacamos o cosmopolitismo, em que as diferenças nacionais foram diluídas na natureza comum de todos os homens e na internacionalização da vida e do pensamento: "Hoje há apenas uma música em toda a Europa [...] esta linguagem universal do nosso continente" ${ }^{\text {. }}$. Além disso, o novo ideal de música de meados do século XVIII incluía a característica de

\footnotetext{
${ }^{79}$ GROUT \& PALISCA, 1988, 475.

${ }^{80}$ CHABANON apud GROUT \& PALISCA, 1988, 477.
} 
ser nobre e agradável, expressiva dentro dos limites do decoro, e "natural", isto é, desprovida de complexidades inúteis técnicas e capaz de cativar qualquer tipo de ouvinte.

O surgimento das formas musicais, como a Sonata, fundou um novo paradigma estético que privilegiava o ouvinte, no sentido de que a música deveria ir ao seu encontro ao invés de obrigá-lo a entender sua estrutura. Seu decoro iluminista exigia que a música deveria cativar e comover através de uma estrutura racional, e que não deveria surpreender ou causar perplexidade com elaborações ou excesso de complexidade ${ }^{81}$. A forma-sonata propiciava não apenas expressão e sentimento, mas um efeito narrativo de intriga e resolução. Isso dava ao texto musical uma independência total das palavras, uma vez que a força expressiva da sonata está concentrada na sua estrutura, na sua larga escala de modulações e na transformação dos temas em novos personagens ${ }^{82}$.

A atividade editorial beneficiou-se de uma grande expansão, pois as publicações musicais destinavam-se prioritariamente aos amadores, e estes criaram a demanda de música fácil de se entender e de se tocar, ao mesmo tempo em que se interessavam em ler e discutir música. É importante destacar que, para as novas formas, recursos como as improvisações e ornamentações tornavam-se obsoletos, garantindo assim, seu significado exclusivamente através de sua estrutura, e não mais da ornamentação virtuosística ${ }^{83}$.

A última obra da longa tradição que enfoca a Folias de Espanha como tema para variações foi publicada em 1778. Trata-se da 12 Variationen auf die Folie d'Espagne in d mineur Wq118/9 - H263, de Carl Philipp Emanuel Bach (1714-1788). Se, por um lado, a Cantata Camponesa de Johann Sebastian Bach, que estudamos neste capítulo, constitui um exemplo marcante do uso sutil da Folia como subtexto, por outro lado não encontramos

\footnotetext{
${ }^{81}$ GROUT \& PALISCA, op.cit., 479.

${ }^{82}$ ROSEN, 1980, p. 10.

${ }^{83}$ GROUT \& PALISCA, ibid., loc.cit.
} 
uma referência tão densa de alusões nas variações para teclado de seu filho: a lógica geral do trabalho de Carl Philipp não passa de mais uma reflexão sobre o gênero Tema e Variações do ponto de vista do estilo e da forma.

O estilo expressivo de C. P. E. Bach explorava o elemento surpresa, com mudanças abruptas de harmonia, estranhas modulações, inflexões melódicas inesperadas, pausas tensas, mudanças de textura, repentinas acentuações. Seu objetivo artístico era expressar os afetos unicamente pela escrita instrumental, o que de outra forma seria muito mais fácil usando a voz ou as palavras. Os aspectos subjetivos e emotivos do Empfindsamkeit (sensibilidade) atingiram seu ápice nas décadas de 1760 e 1770, com o surgimento do estilo literário Sturm und Drang (tempestade e ímpeto), que depois foi absorvido pelas demais artes. Os compositores clássicos posteriores controlariam o excesso de emotividade, que estaria subordinada às diretrizes da unidade entre conteúdo e forma ${ }^{84}$.

O conteúdo e a sensibilidade são os atributos essenciais da abordagem de Carl Philipp ao tema ibérico: suas variações são dramáticas. Se a tradição inspirada em Corelli e Marais privilegiava o charme e as diferenças sutis de variações, as de Bach são radicalmente diferentes em ritmo, textura e humor, com constantes modulações, mudanças de tonalidade, alterações rítmicas, além de um brilhante e expressivo tratamento instrumental ${ }^{85}$.

A apresentação propositalmente simplificada do tema em acordes com arpejos simples cria um efeito de estranhamento na apresentação da primeira variação, repleta de retardos e apogiaturas melódicas, a qual divide cuidadosamente o trabalho entre as mãos. A segunda variação possui uma atmosfera crescente de poder reprimido, enquanto que a

\footnotetext{
${ }^{84}$ GROUT \& PALISCA, op.cit., p.490.

${ }^{85}$ HINSON, 1982.
} 
terceira atinge um efeito sonoro magnífico e moderno em virtude de certas "notas erradas" sutilmente inseridas no arpejo. A variação IV é em estilo imitativo, a seguinte é especialmente impressionante devido à figura de baixo que é perseguida implacavelmente à cadência final. A sexta explora a figura retórica suspiratio e a sétima é inspirada pelo o estilo tecladístico acrobático de Domenico Scarlatti (1685-1757). A oitava está escrita na forma de uma abertura francesa lenta com dinâmicas contrastantes, servindo de introdução para a próxima variação, que explora rápidas figurações. A variação X é imitativa entre as mãos e a XI, um estudo de síncope até os três compassos finais, substituídos por ritmos suaves. A última variação é um moto perpetuo com dedilhado específico indicado pelo compositor, terminando de maneira inesperadamente súbita.

Depois dessa versão de C.P.E. Bach, a Folias de Espanha, que antes satisfazia plenamente os parâmetros retóricos musicais, entrou em franco declínio por não atender mais aos novos ideais estéticos iluministas, tais como as formas narrativas, a facilidade de execução e o cosmopolitismo incorporados pelo Classicismo. 
CAPítulo 3:

RUÍNAS DE UM PASSADO GLORIOSO 


\subsection{Renovação da forma Tema e Variações nos séculos XVIII e XIX}

O desmembramento da Sonata em novas formas durante a metade do século XVIII fez com que as variações sobre o baixo ostinato - na verdade, qualquer tipo de técnica com ostinato - fossem abandonadas ${ }^{1}$. A forma Tema e Variações clássica seria consolidada por Haydn e Mozart em termos de um equilíbrio entre distanciamento e retorno, ao passo que Beethoven, inspirado pelo estilo de Carl Philipp Emanuel Bach, exploraria o aspecto de distanciamento e contrates em relação ao tema principal ${ }^{2}$.

Até meados do século XVIII, o princípio da variação regulava diversos gêneros, como a passacaglia e a ciacona, e muitos desses gêneros continham seções de variantes interligadas. Após o século XVIII, a forma consolidou-se estruturalmente em partes mais definidas, nas quais cada variação possuía equivalência e autonomia formal em relação ao tema. Em diversas obras de Beethoven, as variações passaram a ser coadjuvantes em relação ao tema, como, por exemplo, nas 6 Variações op.34 (1802).

A variação é um procedimento espontâneo na execução musical, utilizado como um recurso para repetir uma idéia sem perder o interesse do ouvinte, porém na forma Tema e Variações ela funciona como princípio estrutural. A escolha do tema pode facilitar ou dificultar a elaboração das variações, assim, se o tema contém muitos elementos não há espaço para adições como num tema simples, especialmente no que se refere à harmonia ${ }^{3}$.

A distribuição das variações passou a ser elaborada de acordo com princípios de contraste, substituindo a prática antiga da unidade, como por exemplo, mesclando-se as variações de caráter com as formais, as líricas com as rítmicas, as lentas com as rápidas,

\footnotetext{
${ }^{1}$ SISMAN, 2009.

${ }^{2}$ Id., Ibid.

${ }^{3}$ SCHOENBERG, 1993, p.201-203.
} 
alternando-se as tonalidades - especialmente após o surgimento da sonata e da sinfonia e/ou as fórmulas de compasso, etc. Schoenberg acrescenta que:

[...] desde Beethoven, a tendência geral tem sido a de construção em direção a um clímax (ou vários pontos culminantes em séries mais longas), que pode ter uma característica emocional, rítmica, dinâmica, de velocidade, ou quaisquer combinações destas. (SCHOENBERG, 1993. p.210).

Cada variação deve possuir algum tipo de afinidade com o perfil básico do tema: melodia, linha de baixo, ritmo, harmonia ou estrutura, ou uma combinação de um ou mais desses elementos. As técnicas empregadas podem estar girando em torno da idéia de alteração de elementos ou de adição sobre eles, e até mesmo de subtração. Esses princípios são freqüentemente combinados entre si. Levando-se em consideração as diferentes relações entre os elementos constantes e variáveis, podemos enumerar alguns tipos básicos de variação, que costumam ser identificados em análises de obras:

- Ostinato: um grupo de notas, de preferência a linha de baixo, permanece constante. Neste tipo de procedimento é comum manter também a harmonia e a forma geral (frases, número de compassos).

- Cantus Firmus: uma melodia, geralmente muito conhecida, permanece intacta ou com apenas um leve ornamento em alguma das vozes ou na voz superior, ou distribuída em tempo mais estendido, diluindo perceptualmente sua presença.

- Harmonia fixa: a harmonia - e geralmente também a forma - permanece inalterada. Esta categoria abrange grande parte do repertório dos séculos XVI ao XVIII, como as romanescas e a Folias de Espanha, originadas a partir de uma linha de baixo projetando uma seqüência de acordes. 
- Melódica: as principais notas da melodia do tema permanecem constantes, ou ligeiramente ornamentadas. Mesmo quando são empregadas alterações de figuração, simplificação ou rítmica, estas não chegam a alterar o reconhecimento de seu perfil.

- Formal: os únicos elementos preservados são a forma e estrutura de frase do tema, produzindo um efeito de afastamento sutil ou radical. É um recurso mais empregado no repertório do século XIX, como por exemplo as Variações sobre um tema de Diabelli (1823) de Beethoven e as Variações sobre um tema de Haendel (1861) de Johannes Brahms.

- Característica: o tema assume o caráter de alguma dança, estilo nacional ou associação programática/onomatopéica, como ocorre no poema sinfônico Dom Quixote (1898), de Richard Strauss.

- Fantasia: também conhecida como "variação livre", costuma manter algum elemento característico do tema principal - à maneira de um leitmotiv, com grande transformação dos aspectos formal e fraseológico. Esse tipo de variação é típico em obras dos séculos XIX e XX, e pode ser ilustrado em obras como os Estudos Sinfônicos (1837) de Robert Schumann ou Nocturnal after John Dowland (1963) de Benjamin Britten.

- Série: utilizado como princípio fundamental da música serialista, a variação é determinada por meio da recombinação de uma ou mais configurações - melódica, rítmica, dinâmica, etc. - em uma ordem determinada. Neste tipo de variação, alguma ordem é alterada ou manipulada, e não o tema propriamente dito. Esta técnica de variação é mais freqüentemente encontrada em obras da primeira metade do século XX, especialmente nos compositores da Segunda Escola de Viena.

Não existem fronteiras e limites que permitam uma classificação fechada sobre o tipo de técnica de variação empregada pelo compositor, pois em grande parte é possível 
identificar uma mistura dos procedimentos arrolados acima ou até mesmo a transição entre técnicas em uma mesma variação.

A própria idéia de variação torna-se, após o século XVIII, um conceito amplo e aplicável a outros gêneros, como por exemplo na seção Durchfürung das sonatas clássicas e românticas, ou nos refrões variados da forma Rondó. Entretanto, em todos os períodos da história da música, a permutação entre o princípio da variação e a forma Tema e Variações foi sempre flexível, sendo que a própria forma incorporou elementos que a aproximou de outros gêneros, como por exemplo a aria da capo (quando o tema é retomado em sua forma literal no final de um conjunto de variações), a sonata (quando uma seqüência de variações é emoldurada por uma introdução e um finale, ou mesmo uma fuga), ou a suíte (quando há inclusão de um intermezzo que não possui relação direta com o tema). 


\subsection{Folias de Espanha em Beethoven: discurso e temporalidade ${ }^{4}$}

A Folias de Espanha utilizada como subtexto possui, como vimos, seu precedente na Bauernkantate de Johann Sebastian Bach, revelando-se como uma eficaz estratégia narrativa a partir de seu próprio percurso histórico e de sua conexão com o antigo regime monárquico francês.

O novo ethos irônico da citação do tema e seu elemento auto-reflexivo é um fator relevante no uso que Beethoven fez dele no segundo movimento de sua Sinfonia N.5 Op.67, escrita entre 1804 e 1808, tanto no aspecto narrativo quanto temporal.

Embora seja provável que Beethoven conhecesse o tema Folias de Espanha em muitas versões diferentes, não existem evidências de que o compositor tivesse tido a oportunidade de ouvir a Cantata BWV 212 de Bach ou de estudar a sua partitura. Martin Geck destaca algumas semelhanças entre esta cantata e algumas obras de Beethoven compostas entre 1806 e 1808, como a Sinfonia N.6 ou o segundo movimento do Quarteto Op.59 n.1 ("Razumovsky”)" Porém nada assegura essas possíveis conexões como fonte direta de inspiração: apenas destacamos o fato de que o uso retórico-discursivo da Folias de Espanha já possuía precedência histórica além da óbvia utilização no repertório instrumental como tema para variações e de sua recente inserção em diversas óperas cômicas.

O pesquisador John Rice comprova que a Folias de Espanha foi uma das melodias mais populares entre os anos 1780 e 1820 em Viena, onde o tema circulava em materiais impressos e manuscritos da música instrumental e da ópera. Através do inventário e dos catálogos de música do editor de música Johann Traeg, sabe-se que as Sonatas Op.5 de

\footnotetext{
4 A discussão que será desenvolvida neste capítulo está baseada em um artigo inédito elaborado pelo musicólogo italiano Stefano Mengozzi, da Universidade de Michigan.

${ }^{5}$ GECK, 2006, p.292.
} 
Corelli estavam circulando na capital austríaca em meados da década de 1790. Traeg também publicou as variações de C. P. E. Bach em $1804^{6}$. Outras inserções do tema estão presentes em diversas óperas cômicas e bufas, além de uma orquestração da Sonata $L a$ Folia de Corelli realizada por Joseph Leopold Eybler (1765-1846), arranjada para a imperatriz Maria Tereza e preservada nos arquivos musicais da corte austríaca ${ }^{7}$.

Alguns autores vão ainda mais longe e procuram possíveis conexões em outras obras de Beethoven - como, por exemplo, na Sinfonia N.4 (compassos 89-92 do primeiro movimento), na Sonata para piano Opus 109 (compassos 27-32 do primeiro movimento), no Concerto Triplo Op.56 (compassos 35-36 do primeiro movimento) - e de outros autores, como na Serenata K.320 (compassos 17-21 do $6^{\circ}$ movimento) de Mozart, na Sinfonia N.90 (compassos 2-4 da introdução) de Haydn e na Sinfonia N.4 de Bruckner (compassos 532-533 do $4^{\circ}$ movimento) ${ }^{8}$. Entretanto, é necessário usar o bom senso, pois, como vimos na tradição renascentista, a linha de baixo da Folia e sua posterior harmonização, por ser uma condensação de várias seqüências semelhantes, pode estar presente em qualquer obra. Especialmente a partir do Classicismo, em que diversos modelos de combinação de acordes herdados da tradição instrumental assumem formatos cadenciais, muitas obras podem conter uma moldura harmônica semelhante, ou até mesmo idêntica, a Folias de Espanha, sem necessariamente haver uma citação direta.

Há pelo menos três aspectos relevantes sobre o aparecimento da Folias de Espanha no Andante com moto da $5^{a}$ Sinfonia de Beethoven: em primeiro lugar, a estrutura de frase da variação em modo menor introduz um elemento de regularidade e previsibilidade ao movimento, que por sua própria qualidade anti-dramática faz com que o momento de

\footnotetext{
${ }^{6}$ RICE, 2006, pp.85-86.

${ }^{7}$ Id., ibid., p.94.

${ }^{8}$ HOYT, 1982, p.196-198.
} 
aparecimento da Folias de Espanha seja maçante o suficiente para baixar mais um degrau no discurso retórico da sinfonia; segundo, sabe-se que o compositor - por meio do estudo dos rascunhos dessa sinfonia - mudou de idéia diversas vezes até decidir a localização exata dessa variação durante o processo de composição, até o momento de finalização da partitura completa ${ }^{9}$; finalmente, seu isolamento na estrutura geral do movimento, devido à sua tonalidade remota, ao seu rebaixamento dramático e às longas transições antes e depois de seu aparecimento, são aspectos que contribuem para conferir-lhe uma ambientação fortemente arcaica, conforme veremos adiante.

De maneira análoga, Beethoven repete a estratégia retórica no primeiro movimento do Concerto para piano N.5 "Imperador" (1809), citando novamente o tema Folias de Espanha de maneira trivial e monótona, antes da reafirmação do segundo tema no modo maior:

${ }^{9}$ MEREDITH, 1991, pp.102-121. 


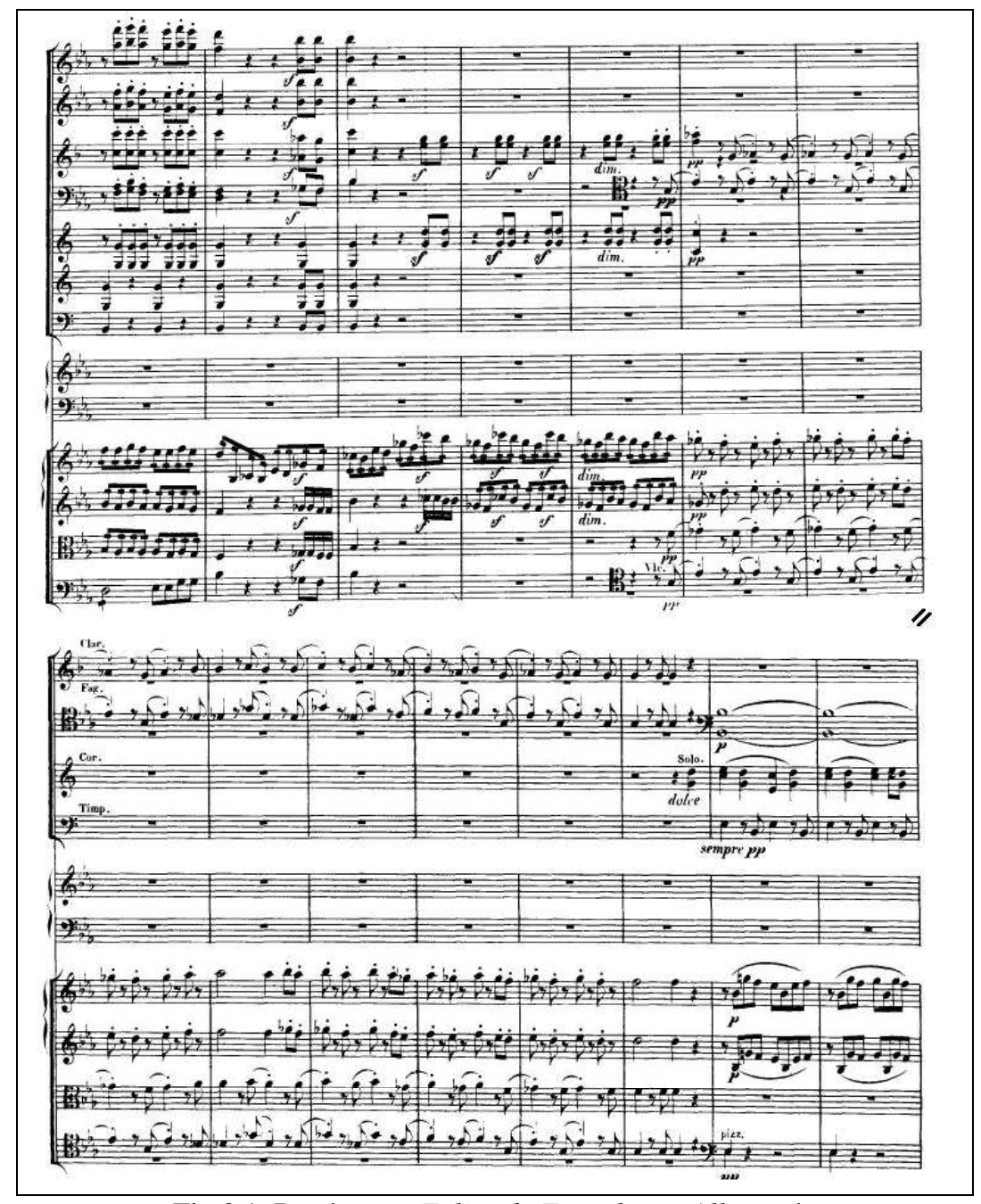

Fig.3.1: Beethoven: Folias de Espanha no Allegro do

Concerto para piano N.5, compassos 5-13 (da figura).

Os dois exemplos, provenientes de obras com menos de um ano de distância entre si, bem como o modo de apresentar a Folias de Espanha em cada um deles, revelam que o compositor alemão não estava interessado em meramente prestar mais uma homenagem ao tema, mas sim utilizá-lo como pretexto para ressaltar outros temas mais importantes do ponto de vista estrutural. Além disso, há de se destacar o deslocamento de função ocasionado pelo uso da melodia como variante, e não como tema gerador. Assim, o uso da Folias de Espanha na $5^{a}$ Sinfonia assume um caráter semiótico que carrega uma narrativa 
subliminar, ou talvez abertamente significativa - dependendo do tipo de ouvinte. Esse procedimento poderá lançar luzes sobre a compreensão das funções estética e narrativa de toda a sinfonia, que foi concebida como uma grande unidade dinâmica.

Um dos compositores que influenciaram a segunda fase de Beethoven foi o italiano, radicado em Paris, Luigi Cherubini (1760-1842), embora esta influência tenha sido “minimizada por respeitados historiadores preocupados em preservar a pureza da sucessão austro-germânica" ${ }^{\prime 10}$. Beethoven conheceu Cherubini em sua visita a Viena em 1805 e era um entusiasta de sua música, chegando a declarar que ele era um dos maiores compositores $\operatorname{vivos}^{11}$. A influência do compositor ítalo-francês pode ser reconhecida em várias de suas obras, como na ópera Fidelio e também no estilo heróico de algumas de suas aberturas, como Egmont e Coriolano ${ }^{12}$.

A ópera Hôtellerie Portuguese de Cherubini estreou em Viena no ano de 1803, tendo sido apresentada nos teatros de corte em 17 récitas e vista por Beethoven. A abertura desta ópera contém uma citação direta da primeira frase do tema Folias de Espanha (até a semi-cadência sobre a dominante), sendo possivelmente a primeira versão para orquestra sinfônica do antigo tema ibérico. Beethoven aproveita a melodia da mesma maneira que Cherubini apresentou na abertura desta ópera, interrompendo-a também na semi-cadência, porém prolongando o acorde de dominante por mais três compassos.

É interessante observar que Cherubini aponta, talvez de forma intuitiva, para a origem portuguesa do tema - algo que seria debatido mais de um século adiante pelos musicólogos na disputa entre suas origens espanholas ou portuguesas. A citação aqui é

\footnotetext{
${ }^{10}$ DEANE, Basil apud DEAN, 1966, p.871. No original: "Cherubini's influence on Beethoven has been minimized by reputable historians anxious to preserve the purity of the Austro-German sucession".

${ }^{11}$ BROYLES, 1987, p.119.

${ }^{12}$ Id., ibid., pp.120 e 144.
} 
bastante simples e direta, como um símbolo da cultura ibérica que seria facilmente reconhecido pelo público parisiense, que estava mais do que habituado a ouvir o tema há, pelo menos, mais de um século. Curiosamente, o mesmo compositor retomou a Folias de Espanha em 1813, na forma tradicional tema e variações, no balé do primeiro ato de sua ópera Gli Abencerragi.

Ao considerarmos a influência ainda presente do espírito revolucionário-francês em diversos temas da Sinfonia N.5 - especialmente na fanfarra do Andante con moto, percebemos que a inclusão da Folias de Espanha como variação é um elemento desconcertante e deslocado em termos discursivos.

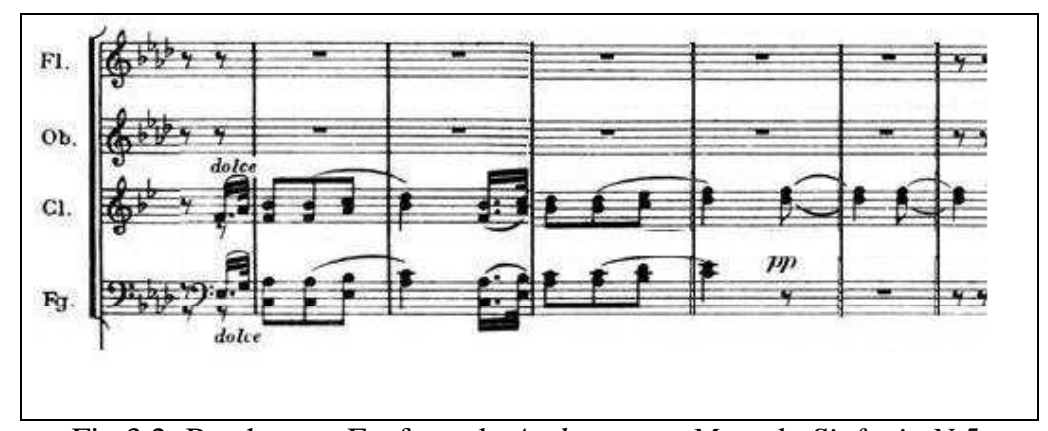

Fig.3.2: Beethoven: Fanfarra do Andante con Moto da Sinfonia N.5.

Para Michael Broyles, a música revolucionária francesa, em geral, possui quatro aspectos básicos: seriedade e grandeza, gestos militares, qualidade vocal, sonoridades massivas ${ }^{13}$. Herbert Schneider descreveu o élan triomphal do hinário revolucionário francês, que pode ser identificado, além dos aspectos levantados por Broyles, pela organização estrutural em torno do gesto da forma-refrão (Refraingestalt) ${ }^{14}$. A partir de 1790, o hino revolucionário adotou a forma-refrão do tradicional vaudeville para expressar

\footnotetext{
${ }^{13}$ BROYLES, 1987, p.125

${ }^{14}$ SCHNEIDER, 1988, p.421-478.
} 
a mensagem de otimismo, como um símbolo da vitória final do povo contra as forças do antigo regime monárquico:

\begin{abstract}
A mudança da estrutura do refrão, do retorno descontraído na canção do regime antigo até o ponto culminante empático do hino revolucionário não foi uma abstração estética, um procedimento musical, mas tinha uma função política comunitária/social. (SCHNEIDER apud KOSELLECK \& REICHARDT, p.457. Tradução de Bernhard Fuchs). ${ }^{15}$
\end{abstract}

O passo definitivo para a consolidação da forma-refrão revolucionária foi a introdução de um episódio em modo menor, cuja finalização ocorre em uma nota sustentada por fermata, imediatamente antes do refrão no modo maior, a fim de gerar um efeito de catarse auditiva. Este tipo de organização estrutural - episódio (modo menor), fermata, hino triunfal (modo maior) - transformou-se rapidamente em um gesto retóriconarrativo convencional que simboliza as luzes após as trevas, e que pode ser identificado, de maneira mais elaborada, em diversas obras: em todos os movimentos da própria Sinfonia N.5 de Beethoven, assim como no primeiro movimento do Quarteto em Dó maior Op.76 N.3 "Imperador" de J. Haydn, dentre outras.

Estudiosos da relação entre Beethoven e a Revolução Francesa, tais como Arnold Schmitz, Beate Angelica Kraus e Peter Gülke ${ }^{16}$, identificaram semelhanças melódicas surpreendentes entre os temas da Sinfonia N.5 e diversos hinos revolucionários de autores como Cherubini, Lisle, Lacombe, dentre outros ${ }^{17}$. As próprias óperas de Cherubini

\footnotetext{
${ }^{15}$ No original: "Der beachtete Strukturwandel des Refrains vom lockeren Kehraus im Lied des Ancien Régime zum emphatischen Höhepunkt der Revolutionshymne war kein abstrakt-ästhetischer, rein musikalischer Vorgang, sondern hatte eine politisch-gesellschaftliche Funktion"

${ }^{16}$ SCHMITZ, 1927, pp.166-167; BOYD, 1992, pp.302-314; GÜLKE, 1978, p.51.

${ }^{17}$ As obras revolucionárias citadas por MENGOZZI (2003, pp.23-24) que possuem relações motívicas com a Sinfonia N.5 são as seguintes: Hymne du Panthéon de Luigi Cherubini (relação intervalar idêntica entre as palavras "nous jurons tous" e o motivo do "destino". Para GÜLKE, 1978, pp. 51-52, o texto dramático do hino já é uma antecipação do terrível ímpacto na abertura da sinfonia: Sobre o vosso caixão heróico/Juramos todos com ferros nas mãos/Morrer pela Revolução/E pelos direitos da humanidade [no original: "Sur votre cercueil héroique/Nous jurons tous le fer en main/De mourir pur la Révolution/Et pour les droits du genre humain", tradução nossa]); Hymne Dithyrambique de Rouget de Lisle (ritmo pontuado e ascensão melódica
} 
representavam o meio mais sofisticado de expressão das idéias e da retórica típicas da música revolucionária francesa ${ }^{18}$. Beethoven conheceu muita música revolucionária francesa por volta de 1800 por meio da amizade com o general Jean-Baptiste Bernadotte (1763-1844), que possuía exemplares da revista Magasin de Musique, os quais continham músicas propagandísticas e hinos dos compositores franceses filiados à causa revolucionária.

Apesar das conexões entre Beethoven e o movimento revolucionário, o compositor não se limitou a meramente citar os temas e adotar as estruturas típicas da música francesa, mas foi além criando um novo tipo de discurso musical, articulando as sessões em períodos extensos e incluindo o elemento da temporalidade para valorizar ainda mais o aspecto dramático da narrativa. Se, por um lado, os hinos triunfais adotam a forma-refrão como um elemento previsível e conhecido de antemão pelos ouvintes, a apropriação feita por Beethoven em suas sinfonias e aberturas é realizada de maneira gradual e planejada, através de prolongados crescendos orquestrais nos quais o ouvinte nunca sabe ao certo quando acontecerá a catarse. O efeito psicológico geral da escuta, em Beethoven, é muito mais permanente.

Uma das estratégias formais de Beethoven é o uso da repetição da capo transfigurada, procedimento que se coaduna tanto à ideologia revolucionária quanto ao novo conceito sinfônico beethoveniano enquanto processo dinâmico. Tal procedimento já é perceptível na Sonata Op.57 “Apassionata” (1804-1806) cuja tradicional repetição temática da capo na recapitulação incorpora elementos motívicos gerados no desenrolar do desenvolvimento. O efeito temporal desta nova estratégia narrativa - repetição variada com 
elementos do passado - lança o ouvinte, usando uma terminologia agostiniana, ao "presente do futuro"; substituindo a tradicional experiência temporal da repetição da capo, em que se projeta uma temporalidade do tipo "presente do passado"19. Eduardo Seincman esclarece essa questão, afirmando:

[...] o tempo adquire no classicismo um sentido histórico, não exatamente épico, mas sobretudo dramático. Ao contrário da forma barroca que operava a partir da justaposição e do conflito das partes, a forma clássica adquire um caráter orgânico, um sentido de evolução, de desenvolvimento, de elaboração, em que as partes contêm em si o germe de seus futuros desdobramentos e se metamorfoseiam umas nas outras. Assim, o passado não conta mais porque é somente lembrança, mas porque de fato impregna e toma parte das ocorrências do presente. As sínteses ou imagens do passado tornam-se, assim, eixos sincrônicos que se superpõem aos eixos diacrônicos da performance consubstanciando, com isso, as expectativas ou imagens do futuro no presente. $\mathrm{O}$ presente, assim deslocado das coisas presentes, torna-se tenso e denso, e na relação da obra com o ouvinte este é transportado ora mais ao passado, ora mais ao futuro, ou mesmo, em determinadas circunstâncias, colocado em estado de pura suspensão. (SEINCMAN, 2008, p.64).

O conceito tradicional de história cíclica foi substituído pelo da história do progresso, alinhada aos ideais iluministas e revolucionários que toda sociedade civilizada deveria cumprir rumo às etapas superiores de organização e produção. A própria elite francesa já possuía a mentalidade baseada na busca pela novidade, em lugar da antiga valorização das tradições, mesmo antes da revolução:

\begin{abstract}
O 'velho regime' [...] não era uma sociedade trêmula caminhando para o túmulo. Longe de parecer moribunda, sinais de dinamismo e energia podem ser encontrados em qualquer lugar que o historiador observe. Abaixo do rei, a elite estava menos obcecada com a tradição do que pela novidade, e menos preocupada com o feudalismo do que com a ciência. No grande pilar do Louvre estava abrigada não apenas a Académie Française e as academias de pintura e inscrições e medalhas, mas aquelas de ciência e a mais recente fundação real, a Academia de Medicina. (SCHAMA, 1989, p. 185, tradução nossa). ${ }^{20}$
\end{abstract}

\footnotetext{
${ }^{19}$ AGOSTINHO, 1999, PP.322-325.

${ }^{20}$ No original: "The "old regime" [...] was not a society doddering its way to the grave. Far from appearing moribund, signs of dynamism and energy may be found wherever the historian looks. From the King downward, the elite were less obsessed with tradition than with novelty, and less preoccupied with feudalism than with science. In the great pile of the Louvre were housed not just the Académie Française and academies of painting and inscriptions and medals, but those of science and the latest royal foundation, the Academy of Medicine”.
} 
Reinhold Brinkmann também observa que uma das mais dramáticas mudanças trazidas pela revolução foi a noção de aceleração e escalonamento na experiência humana do tempo, ou seja, um modo inteiramente novo de se experimentar o tempo, que culminou na concepção moderna de história baseada no progresso. Ele ressalta que essa nova experiência foi absorvida por Beethoven desde a Sinfonia Eroica, que a traduziu para o discurso sonoro por meio da temporalização da forma musical:

Forma enquanto arquitetura é simetria construída, referência a um centro, à figura do círculo, ao permanecer-em-si-mesmo. Forma enquanto processo é direcionalidade, movimento dinâmico para diante, a metáfora da flecha, e uma ênfase na orientação da finalidade e meta na forma musical. Composições do tipo forma como processo são destinadas tanto ao percurso quanto à meta. Em relação ao percurso, os modelos descritivos usuais referem-se a compor tematicamente e em extensão quase-lógica [...] Mais importante é o conceito de forma como uma cadeia de eventos os quais invariavelmente referem-se além de si mesmos, uma cadeia de eventos que não concluem mas progridem, empurrando continuamente para frente, nas quais os processos geram uma experiência dinâmica de tempo. (BRINKMANN, 2000, p. 17, tradução nossa). ${ }^{21}$

As estruturas musicais tradicionais, como a forma sonata, não eram adequadas para sustentar a concepção de forma como processo, uma vez que o elemento da repetição traz à tona a lembrança do passado. Com a Sinfonia Eroica, Beethoven propôs um novo tipo de solução a este dilema ao trazer:

[...] conclusões diferentes a partir de situações análogas que estão organizadas uma em relação a outra em termos de intensificação. Acrescente a isso [...] uma acelereção simulada, conquistada por meio do desdobramento do aparato orquestral, criando a experiência de 'tempo torrencial', de um 'fluxo de idéias torrencial e transbordante'. (BRINKMANN, 2000, p. 17, tradução nossa). ${ }^{22}$

\footnotetext{
${ }^{21}$ No original: "Form as architecture is constructed symmetry, reference to a center, the figure of the circle, being-in-itself. Form as process is directedness, dynamic forward motion, the metaphor of the arrow, and an emphasis of the finality and goal orientedness of the musical form. Compositions of the form-as-process variety address both path and goal. As for the path, the usual descriptive models refer to composing thematically and quasi-logical extension [...] More important still seems the concept of form as a chain of events which invariably refers beyond itself, a chain of events that does not conclude but progresses, continually pressing forward, in which the processes create a dynamic experience of time."

${ }^{22}$ No original: "[...] different conclusions from analogous situations that are organized in relationship to one another in terms of intensification. Add to this... a simulated acceleration, achieved through the unfolding of
} 
O movimento Andante con Moto da Sinfonia N.5 é construído na forma Variação Dupla $^{23}$, em que o tema gerador não é mais a Folias de Espanha, mas sua sétima variação. Na verdade, conforme será demonstrado, seu papel histórico de protagonista gerador é totalmente revertido, pois sua inclusão neste movimento possui um caráter arcaico e antiheróico, estrategicamente essencial para destacar os temas mais importantes do movimento. A forma geral do movimento está organizada na seguinte configuração:

- Tema A: compassos 0-22;

- $\quad$ Tema B (Fanfarra): compassos 22-49;

- Variação A1: compassos 49-71;

- Tema B' (Fanfarra): compassos 71-98;

- Variação A2: compassos 98-127;

- Variação A3 (Episódio): compassos 127-147;

- Tema B" (Fanfarra): compassos 147-166;

- Variação A4 (Folias de Espanha): compassos 166-184;

- Variação A' (Tema A, da capo): compassos 185-205;

- Codetta: compassos 205-229;

- Coda: compassos 229-247.

Em resumo:

the orchestral apparatus, [which] creates the experience of 'torrential time,' of a 'torrential and overflowing stream of ideas'."

${ }_{23}$ Variação Dupla é um dos desdobramentos formais da tradicional forma Tema e Variações, no qual são apresentados dois temas (A e B) ao invés de um, com variações alternadas de cada tema (A1, B1, A2, B2, etc.). Este formato particular foi utilizado inicialmente por Carl Philipp Emanuel Bach (Cf. Sonata VI, em Dó menor, W. 50/6, H. 140, escrita em 1760) e retomado em diversas obras de Joseph Haydn a partir da década de 1770. Beethoven abordou essa forma de maneira particular, em que o tema $\mathrm{A}$ é mais variado que o $\mathrm{B}$, que geralmente permanece intacto (A1, B', A2, B"'); além do fato do discurso beethoveninano ser mais assimétrico que o de Haydn por meio de interrupções e truncagens de um dos temas ou de ambos. Outras obras de Beethoven que empregam a Variação Dupla são: Sinfonia N.3 (iv), Trio para Piano Op.70/2 (ii); Sinfonia N.7 (2), Sinfonia N.9 (3) e Quarteto de Cordas N.15 (iii). 


\section{A | B | A1 | B' | A2 |A3 | B', | A4 | A' | Codetta | Coda ||}

Tab.3.1: estrutura geral do Andante con Moto da Sinfonia N.5.

Uma breve descrição de cada seção irá esclarecer as funções discursiva e temporal da Folias de Espanha na variação A4. O tema A, em Lá bemól maior, possui um contorno assimétrico, mais assemelhado às estruturas do estilo de concerto italiano do Alto Barroco ${ }^{24}$ do que à quadratura do arquétipo clássico, que lhe confere uma coloração de música antiga e remete a uma temporalidade de uma época passada:

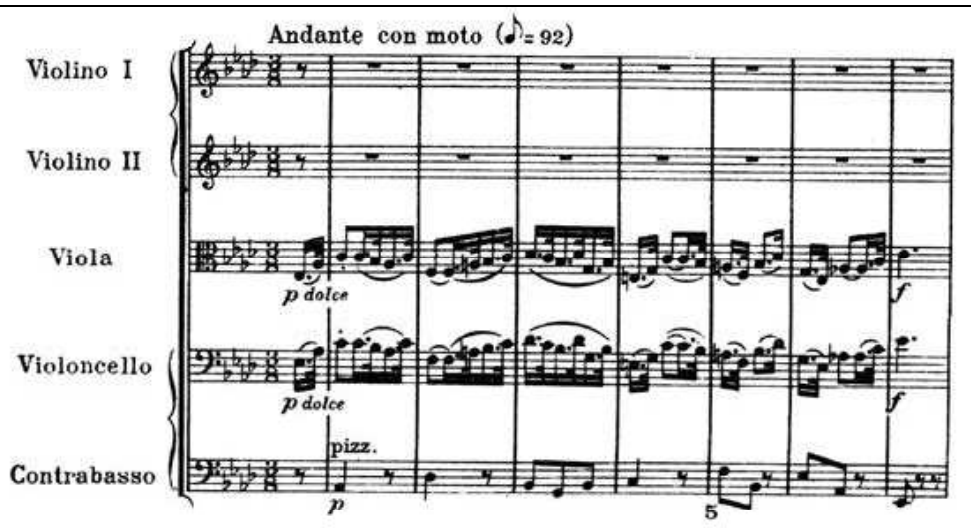

Fig.3.3: Beethoven: Tema A do Andante con Moto da Sinfonia N.5, compassos 0-7.

O tema B (fanfarra) possui exatamente o perfil dos hinos revolucionários franceses descrito por Broyles e Schneider, porém possui uma estrutura incompleta: a frase antecedente não possui sua natural contrapartida, a frase conseqüente, além de um estranho prolongamento da célula inicial pontuada sobre a tríade maior da tônica repetida três vezes

\footnotetext{
${ }^{24}$ Referimo-nos à estrutura adotada por compositores como Vivaldi, Albinoni, Bach, a qual Wilhelm Fischer tipificou numa estrutura tripartida (Fortspinnungstypus): Vordersatz (abertura), Fortspinnung (desenvonlvimento) e Nachsatz (epílogo). FISCHER apud McVEIGH \& HIRSHBERG, 2004, pp.12-13.
} 
- e em seguida mais cinco vezes na repetição, deixando a atmosfera geral do tema B em suspensão:

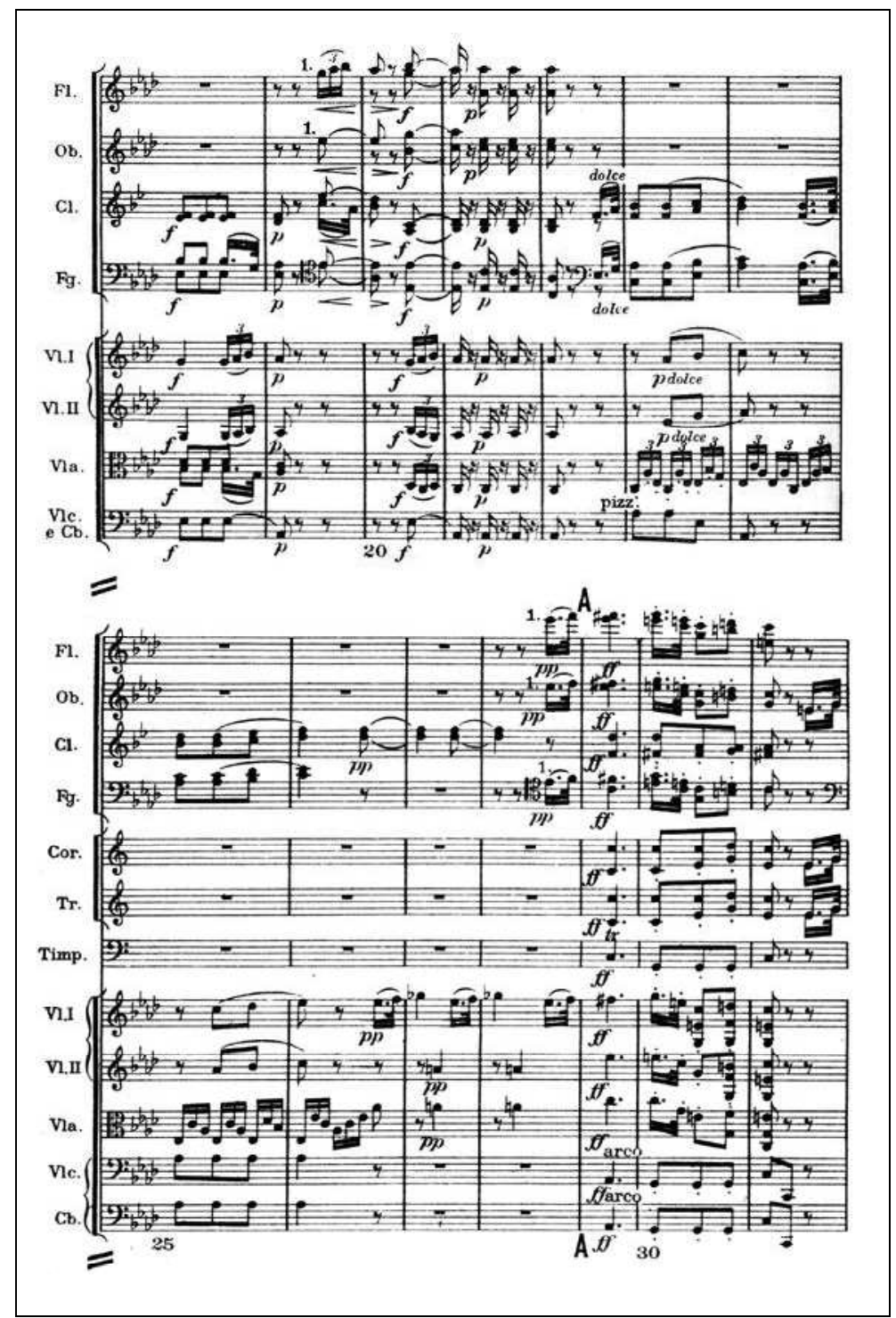

Fig.3.4: Beethoven: Tema B do Andante con Moto da Sinfonia N.5, compassos 18-31.

Após a repetição enfática da célula pontuada e de uma transição de acordes de 8 compassos, ouvimos a primeira variação do primeiro tema (A1), mais rica e ornamentada, dissipando o caráter afirmativo dos temas A e B. A fanfarra (B') é retomada sem alterações nos contornos melódico e harmônico, mas com leves alterações no acompanhamento e na 
orquestração. As duas variações já remetem à concepção dinâmica de forma-processo beethoveniana, que lança o ouvinte a uma percepção renovada dos eventos passados, envolvendo-o na sensação de experiência do "presente do passado".

A sessão seguinte (A2) repete os mesmo procedimentos de variação de A1, apresentando novas configurações do primeiro tema, concluindo em tom dramático sobre um acorde de dominante em fermata que não será resolvido: ao invés de seguir o curso normal dos eventos e introduzir a fanfarra, a expectativa é frustrada e a tensão prolongada e diluída na seção seguinte (A3) inteiramente construída sobre a região da dominante, que se apresenta mais como um episódio ${ }^{25}$ do que como variação:

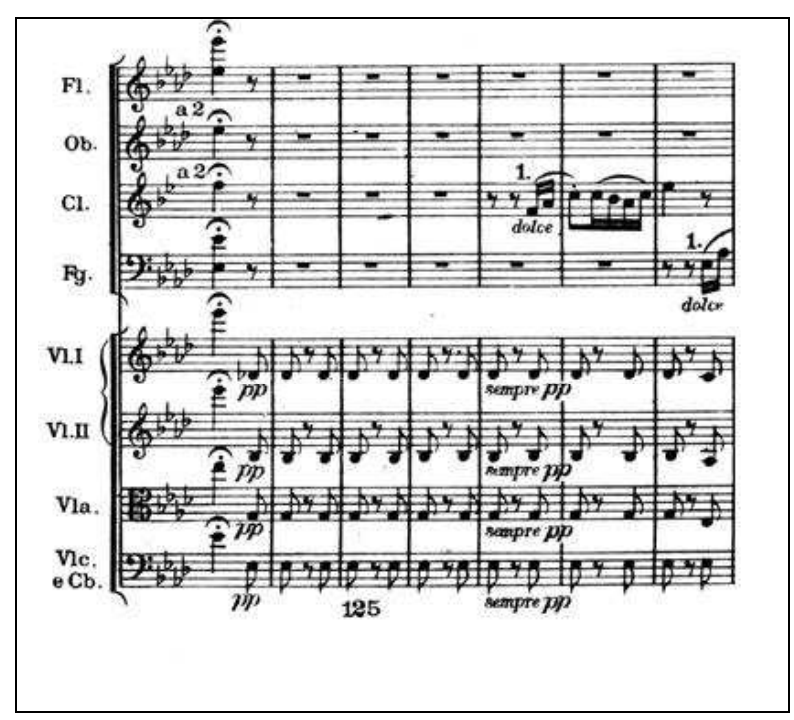

Fig.3.5: Beethoven: acorde sobre a dominante em fermata e início da Variação A3 do Andante con Moto da Sinfonia N.5, compassos 123-129.

Toda a sessão A3 está construída sobre movimentos contrários - nas madeiras e depois nas cordas - que neutralizam a direcionalidade harmônica, gerando um efeito errático e de expectativa. A virada para o acorde de dominante de Dó maior e o crescendo do compasso 146 anunciam, de forma bastante abrupta, a nova erupção do tema B:

\footnotetext{
${ }^{25}$ SCHOENBERG (op.cit., p.189) esclarece que o episódio interrompe o fluxo normal de uma seção, mantendo-se em progressões harmônicas estáticas, sem cadências ou modulações.
} 


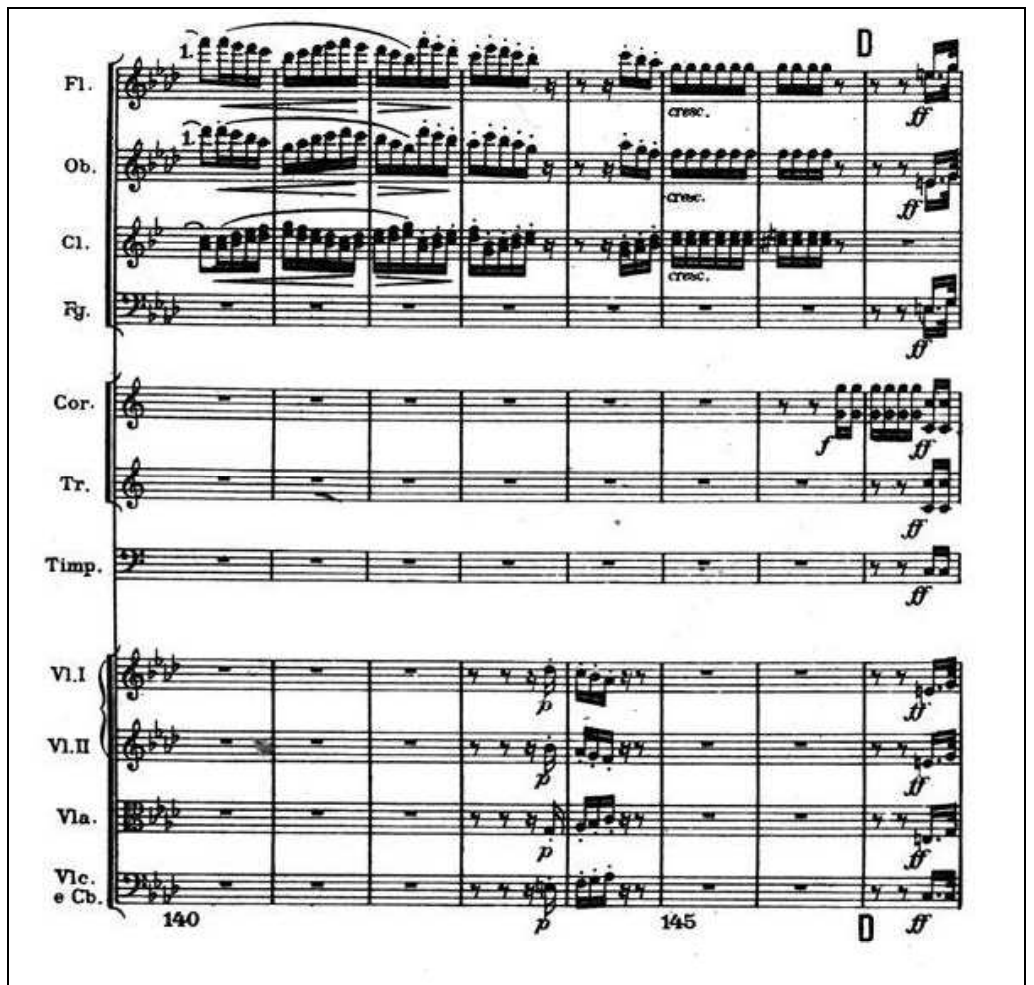

Fig.3.6: Beethoven: início da Variação B” do Andante con Moto da Sinfonia N.5, compassos 140-147.

Esse talvez seja o momento mais apoteótico do Andante, com uma pesada orquestração em tutti, porém após a já conhecida repetição da célula pontuada sobre a tríade maior, presenciamos um efeito de anti-catarse, com um "final morto", seguido de tentativas para recuperar o movimento (compassos 157 a 161), cujo clima de indecisão converte-se em um monótono acompanhamento prolongado por 5 compassos, à maneira dos antigos perfis de variações instrumentais - não sem uma certa dose de ironia, que possui a finalidade de introduzir o tema da Folias de Espanha: 


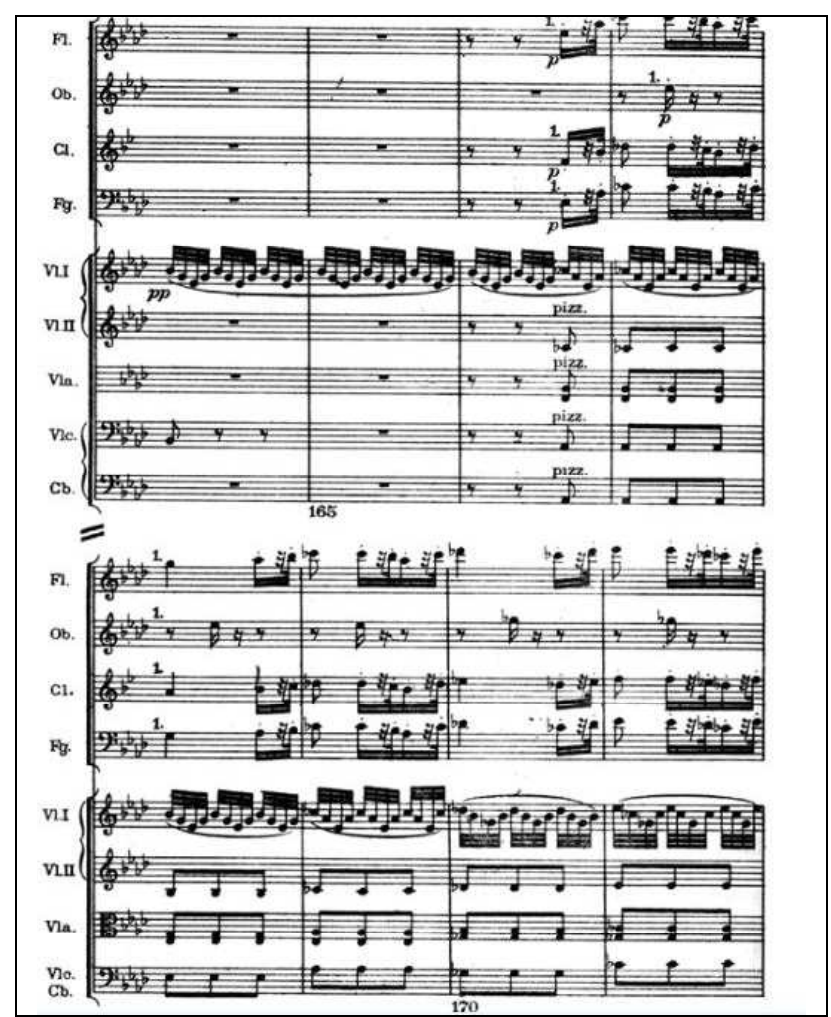

Fig.3.7: Beethoven: transição e Variação A4 (Folias de Espanha) do Andante con Moto da Sinfonia N.5, compassos 164-171.

O uso da tonalidade menor, o acompanhamento em pizzicato das cordas e a dinâmica geral em piano conferem a esta variação um clima obsoleto, arcaico. A estratégia narrativa revela-se, desde o anticlímax da fanfarra (B"), como um fracasso planejado. A recorrência do intervalo de $4^{\mathrm{a}}$ diminuta descendente (compassos 168 e 178) reforçam o caráter anti-heróico, como uma antítese perfeita à $3^{\text {a }}$ maior ascendente, que é o traço heróico da sinfonia. A citação da Folias de Espanha pode ser reconhecida na harmonização (i V i III VII III i V) e nos graus melódicos chave, concluindo apenas na primeira frase sobre a Dominante, que é prolongada por 3 compassos (de 174 a 176) como idéia remanescente do tema B. As platéias francesas, na época das primeiras execuções dessa sinfonia, certamente devem ter identificado algum ranço do antigo regime melhor do que os vienenses nesta versão transfigurada da Folias de Espanha. A referência que Beethoven faz 
e sua elaboração em termos narrativos é tão sofisticada que dificulta seu reconhecimento imediato, especialmente para as platéias de hoje.

Após uma inusitada síncopa, a música assume novamente o caráter vagante, com escalas ascendentes na extensão de $4^{\mathrm{a}}$ diminuta, inicialmente apresentadas pelas flautas e pelo clarinete, passando para os violinos e depois aos violoncelos, como uma expansão contrapontística da região da dominante. Depois da entrada dos violoncelos, o movimento de escala é ampliado, com um grande crescendo orquestral para o objetivo final do movimento, que á a repetição da capo do primeiro tema (A'), em nova roupagem orquestral que se alinha com o élan triunfal da fanfarra. A elevação de espírito sugerida nesta reprise talvez possa representar uma representação de celebração de um tema de perfil antigo - o tema A com sua estrutura tripartida do concerto italiano, que após a experiência da lembrança de um regime antigo e corrupto - simbolizado pela Folias de Espanha - assume um perfil heróico dignificante. Podemos dizer que trata-se de um procedimento retórico que simboliza os ideais iluminista e revolucionário em termos puramente musicais.

A codetta possui uma atmosfera momentaneamente otimista e leve, evocando, mozartianamente, a tradição da ópera bufa. Sua função estrutural parece ser a de equilibrar os humores preparando o retorno da tonalidade trágica de Dó menor no scherzo que se segue. 


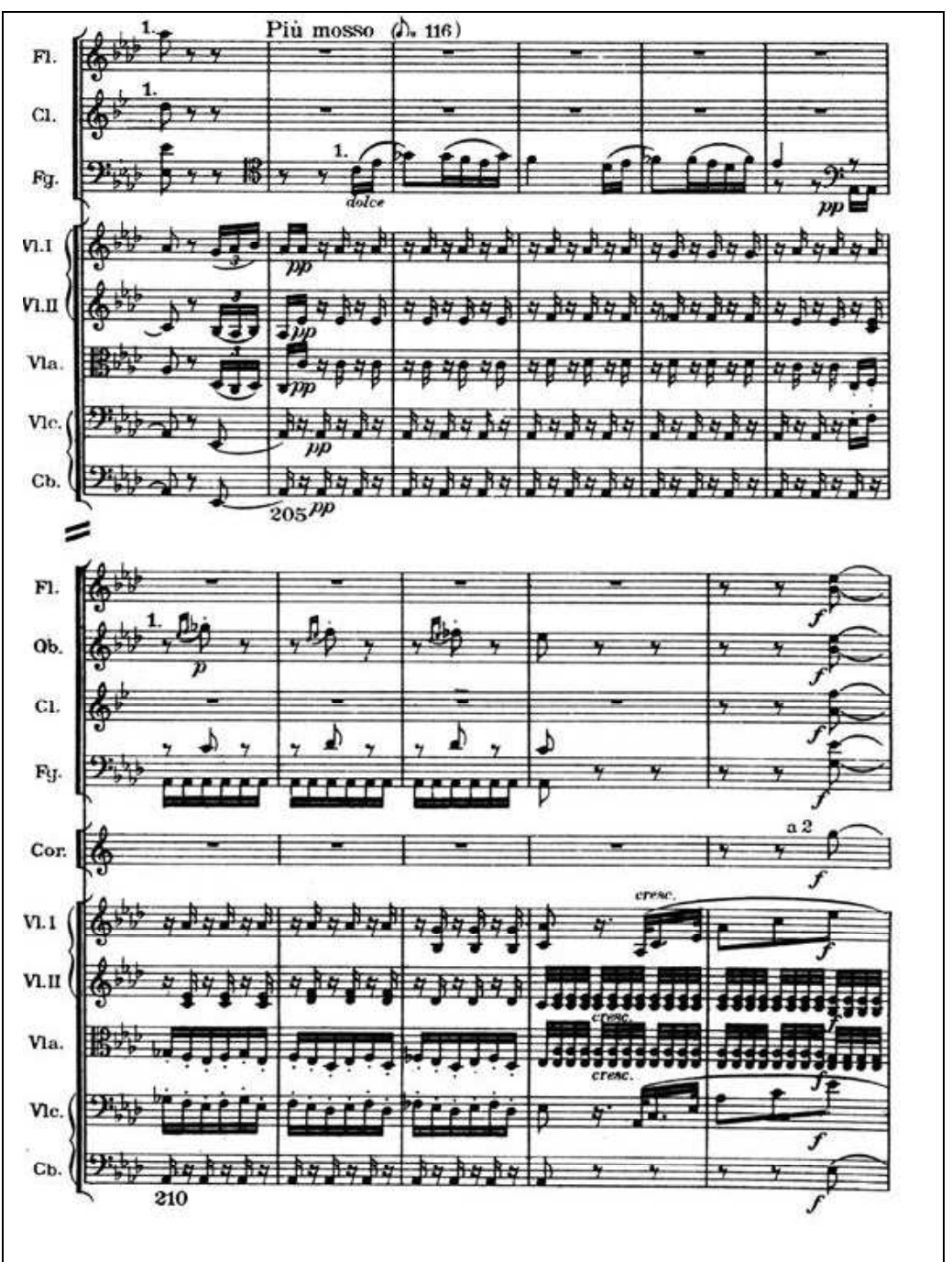

Fig.3.8: Beethoven: Codetta do Andante con Moto da Sinfonia N.5, compassos 204-214.

O movimento conclui com a figura pontuada sobre a tríade maior da tônica como gesto final, que talvez tenha sido o motivo mais repetido em todo o andante, e talvez uma resposta, ao mesmo tempo um complemento, à questão formulada no primeiro movimento pelo famoso tema do destino: duas terças descendentes.

O Andante con moto não está associado a uma visão escatológica da experiência e consciência humanas, como nos demais movimentos da Sinfonia N.5, mas aos aspectos de sua historicidade. Esta é revelada através de referências temporais que se desdobram em 
pequenos quadros, iniciando com um olhar sobre o passado (na estrutura barroca do tema A), passando por momentos triunfais (tema B), crises (A4) e longas esperas (episódio e transições).

Além disso, a música contém aspectos de ironia, particularmente na variação sobre a Folias de Espanha e no gesto operístico da codetta, contrabalançando o tom trágico que permeia toda a sinfonia, que afinal das contas, trata justamente da questão do destino e da irreversibilidade do tempo. 


\subsection{A época de ouro da guitarra romântica}

Embora o século XVIII não tenha sido um século essencialmente propício ao desenvolvimento da guitarra, foi quando houve o acréscimo da sexta corda, fazendo emergir todo seu potencial expressivo. Com a sexta corda, foram abandonadas as cordas duplas e o instrumento adquiriu doçura e suavidade, som redondo e aveludado, e maior variedade de expressão tímbrica.

Esse novo instrumento derrubaria todos os outros modelos, incluindo o alaúde, e sua aceitação tornou-se universal, espalhando-se rapidamente por toda Europa e pelo continente americano. A intensa atividade na área da performance foi equiparada pelos esforços de luthiers que produziam instrumentos de qualidade superior. Os frutos de tal progresso foram colhidos pelos guitarristas do Ottocento, que valorizaram o significado histórico e musical do instrumento.

A Europa, especialmente nas duas primeiras décadas do século XIX, testemunhou o surgimento de duas escolas guitarrísticas importantes: a Italiana - mais influente no ambiente europeu centro-meridional, representada por músicos como Mauro Giuliani (1780-1840) e Ferdinando Carulli (1770-1841) - e a Espanhola, viva e essencial pela tradição e pelo valor, imortalizada por músicos como Fernando Sor (1778-1839) e Dionisio Aguado (1784-1849). A escola italiana talvez tenha sido a que mais contribuiu no Ottocento ao desenvolvimento guitarrístico europeu pela maior quantidade de obras e de executantes virtuoses e amadores, dando o ímpeto necessário para o reconhecimento da guitarra romântica como um veículo sério de expressão artística. Muitos guitarristas profissionais emigraram para os grandes centros musicais da época, como Paris e Viena ${ }^{26}$.

\footnotetext{
${ }^{26}$ DUDEQUE, 1994, p.66.
} 
Para entendermos os princípios estéticos da escola italiana, é preciso considerar antes os elementos de reciprocidade na relação entre a guitarra romântica e o violino no início do século XIX. Muitos elementos técnicos que formam a gramática virtuosística individual de alguns instrumentos são resultantes da apropriação de recursos próprios de outros instrumentos. Se, por um lado, esta relação fortalecia o âmbito técnico de um determinado instrumento, por outro alimentava o imaginário do público novecentista, que apreciava muito associar texturas orquestrais no piano ou efeitos de harpa na guitarra. A técnica de escala era, por exemplo, um recurso originário da técnica violonística que foi importado pela guitarra devido à estreita relação entre guitarristas e violinistas, ao passo que os arpejos foram transportados para o violino por inspiração direta da guitarra. A escola italiana manteve essa relação direta com o virtuosismo violinístico por influência de Niccolò Paganini (1782-1840), que inspirou artistas como Giuliani, Carulli, Luigi Legnani (1790-1877) e Marco Aurelio Zani de Ferranti (1801-1878) durante as décadas de 20 e 30 do século $\mathrm{XIX}^{27}$.

A escola espanhola manteve uma posicionamento distante do fenômeno virtuosístico adotado pelos guitarristas italianos. O conceito de "brilhantismo" desenvolvido pelo compositor espanhol Dionisio Aguado em obras como os Três Rondós Brilhantes, de 1882 - compostos no mesmo ano dos 36 Caprichos Op. 20 de Legnani, baseados nos de Paganini - não são nada mais do que a busca do máximo efeito com o mínimo de esforço, exatamente o oposto do objetivo do virtuose, que procura impactar seus ouvintes não apenas pela evidência de um grande esforço, mas também pela expressão e comunicação resultantes dessa energia ${ }^{28}$.

\footnotetext{
${ }^{27}$ SUÁRES-PAJARES, 2004, p.232.

${ }^{28}$ Id., ibid., loc.cit.
} 
Na segunda metade do século 18, o tema Folias de Espanha foi utilizado em muitos métodos de guitarra como um veículo para o ensino de arpejos de mão direita, que aparece com um grande número de variações, cada uma delas explorando uma combinação diferente.

O primeiro guitarrista a publicar variações sobre a Folias de Espanha foi o napolitano Ferdinando Carulli, que iniciou sua carreira como violoncelista mas dedicou-se depois exclusivamente à guitarra, tornando-se um de seus mais aclamados virtuoses e escrevendo 360 obras, além de um importante método. Fez sucesso nos salões da aristocracia de Paris, transformando a capital francesa numa referência da atividade guitarrística européia do início do século XIX. Dele, existem duas versões: a) Les folies d'Espagne et un theme Opus $15 \mathrm{c}$, de 1810 , cujo manuscrito original encontra-se na Biblioteca Musicale G. Greggiati, em Ostiglia, Lombardia; b) Les Folies de Espagne: variées de deux manieres pour guitare ou lyre Opus 75, de 1814, manuscrito localizado na Biblioteca do Conservatório de Nápoles ${ }^{29}$.

Entretanto, as variações mais conhecidas sobre Folias de Espanha foram escritas por Giuliani e Sor. Giuliani foi um dos maiores expoentes da escola italiana da guitarra romântica, iniciando a moda das grandes turnês de guitarristas e propagando a aceitação da guitarra como instrumento de concerto por toda Europa. Sua influência na vida musical de Viena foi profunda: ele inaugurou os concertos com violão e orquestra e tocou com as mais importantes personalidades do mundo musical devido a sua extraordinária habilidade técnica e musical ${ }^{30}$.

\footnotetext{
${ }^{29}$ Não foram encontradas, no decorrer desta pesquisa, partituras, gravações ou referências que permitissem uma análise mais detalhada destas obras de Carulli. A única fonte que aponta a existência dessas variações é a homepage de GABLER, 1997.

${ }^{30}$ HECK, 1995, passim.
} 
Sua obra VI Variations pour la guitarre sur les folies de Espagne, Op. 45 publicada em 1814 é uma das mais revisitadas no repertório violonístico de hoje. Como vimos anteriormente $^{31}$, existia uma enorme difusão da melodia Folias de Espanha em Viena entre o final do século XVIII e início do XIX, que foi acompanhada por um forte interesse editorial no mercado da guitarra romântica, o que nos permite afirmar que todo guitarrista vienense conhecia bem o tema muito antes da publicação de Giuliani em $1814^{32}$. O mesmo pode ter ocorrido em Paris nessa mesma época, com as edições de Carulli e de Sor.

O tratamento do tema na versão de Giuliani é semi-contrapontístico, uma vez que a linha do baixo se movimenta num sentido mais harmônico do que melódico, pontuando as próprias notas dos acordes que acompanham a exposição da Folias de Espanha:

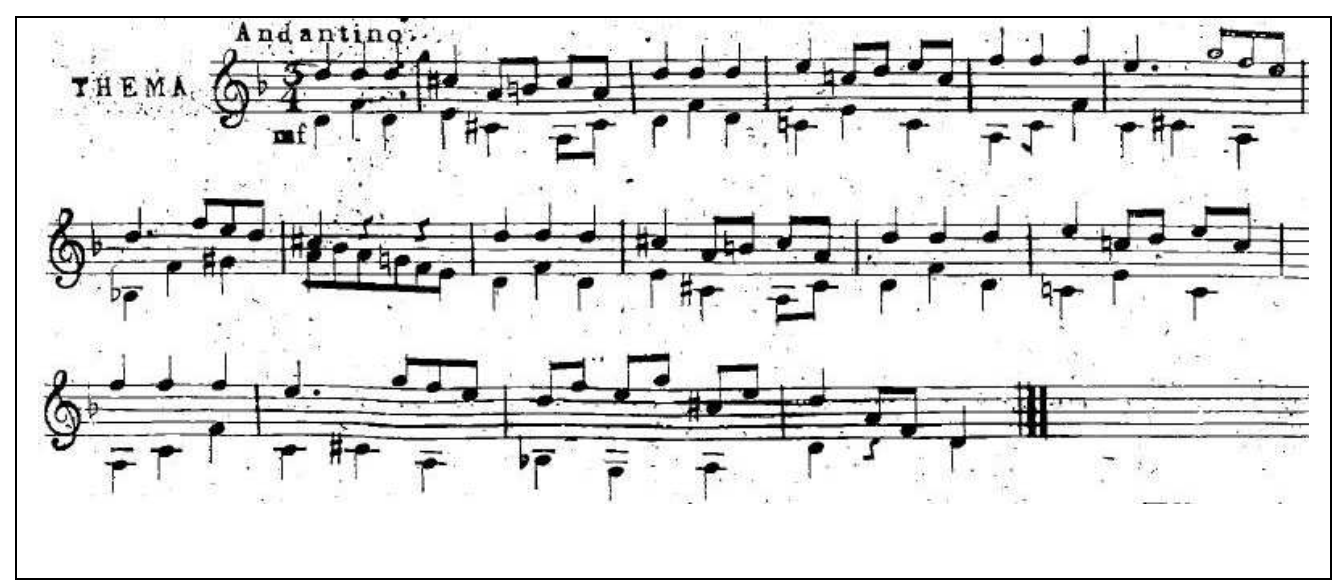

Fig.3.9: Giuliani: VI Variations pour la guitarre sur les folies de Espagne (Tema), 1814.

A primeira variação possui um perfil mais polifônico, numa disposição em imitação a duas vozes, quase em forma de cânone; a seguinte possui um ostinato na voz superior, transferindo a melodia para o grave, lembrando as peças virtuosísticas em movimento perpétuo, ou spinning. A terceira variação é toda construída em arpejos de tercinas, na

\footnotetext{
${ }^{31}$ Cf. capítulo 3.2.

${ }^{32}$ MENGOZZI, 2003, p.7.
} 
região aguda enquanto que a seguinte, a variação IV, explora a figuração de oitavas quebradas, o que produz um belo efeito sonoro e de complexas movimentações na mão esquerda.

Neste conjunto de variações, Giuliani introduz uma variação (V) em Ré maior, que funciona como um intermezzo, na qual o intérprete tem uma oportunidade de explorar a interpretação cantabile. Todo o ambiente afetivo é afetado, inclusive pela primeira indicação de andamento diferente do tema (un poco piú Adagio), pela extensão ampliada de compassos e pela escrita mais transparente. Esse procedimento já não era mais original no repertório de variações da época de Giuliani, mas certamente inaugura um novo elemento ao histórico de procedimentos composicionais da Folias de Espanha.

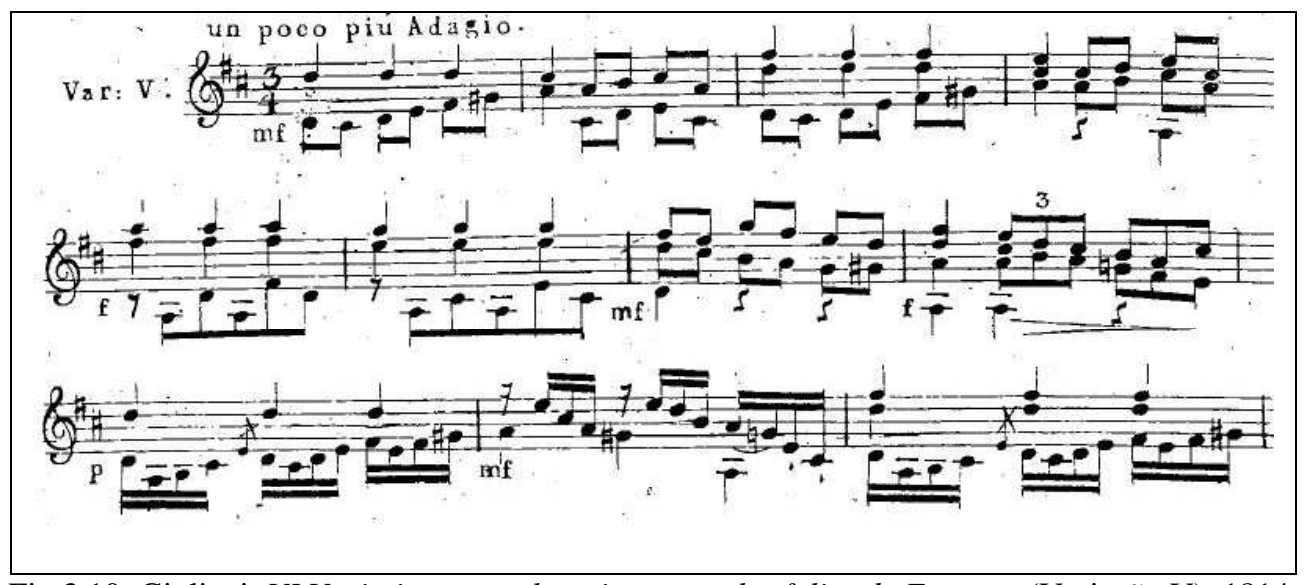

Fig.3.10: Giuliani: VI Variations pour la guitarre sur les folies de Espagne (Variação V), 1814.

A variação VI introduz uma escrita a três vozes, o que também contribui para uma textura mais sonora, em estilo militar. A coda final está interligada com a variação anterior e retoma a idéia do tom maior, subdividida em três partes: uma com um pedal na corda solta ré, passando para um breve trecho em acordes rebatidos que são logo desmembrados em arpejos, numa conclusão triunfante. 
No ano seguinte é editada em Paris a versão das Folias de Espanha do seu contemporâneo Fernando Sor (1778-1839), que foi um dos principais expoentes da guitarra romântica e considerado um dos maiores instrumentistas de seu tempo. Nascido em Barcelona, residiu em Paris entre 1813 e 1815, e mais tarde de 1826 a 1849, e em Moscou entre 1815 e 1823. Trabalhou intensamente como concertista, professor e compositor. Suas composições somam mais de 250 obras, abrangendo desde peças de salão até óperas. Escreveu para a Enciclopédia Francesa de D’Alembert \& Diderot o primeiro verbete oficial sobre danças espanholas como o bolero, a seguidilla e a sevillana. Sua obra para violão inclui sonatas, fantasias, variações e estudos. Sua publicação mais importante foi o Méthode pour la guitare, de 1830, certamente o livro mais notável sobre técnica violonística já escrito ${ }^{33}$.

Suas variações e minueto sobre Folies d'Espagne Op.15 N.1, de 1815, é talvez a primeira versão conhecida em uma tonalidade diferente (Mi menor), o que traz algumas vantagens do ponto de vista técnico: desnecessidade de afinar a $6^{\mathrm{a}}$ corda em ré, maior uso de cordas soltas, desenhos de mão esquerda mais simétricos no âmbito harmônico, possibilidades ampliadas de harmônicos naturais.

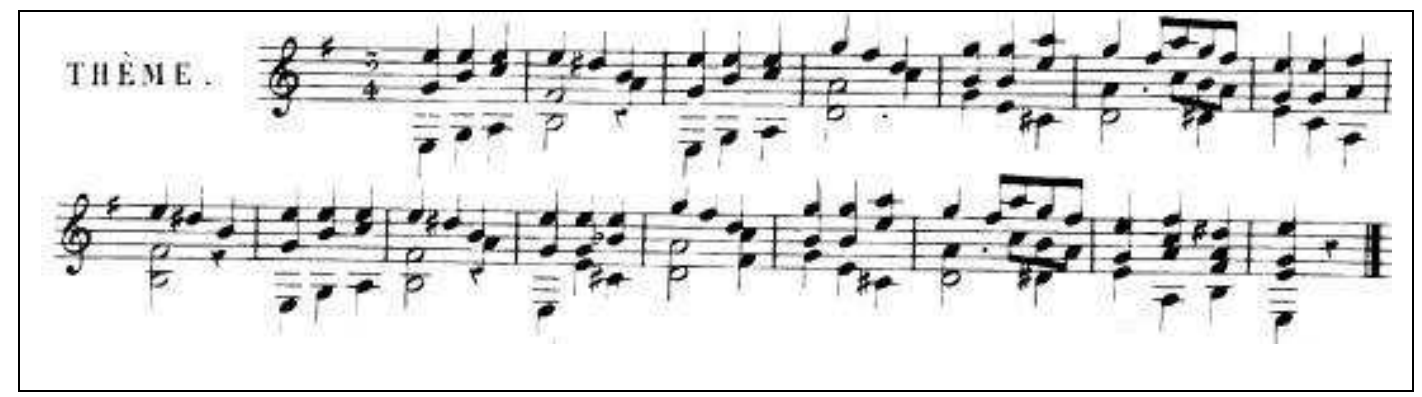

Fig.3.11: Sor: Folies d'Espagne (1815), tema

\footnotetext{
${ }^{33}$ Cf. versão traduzida e comentada de CAMARGO, 2005.
} 
A própria exposição temática, em acordes ascendentes a três vozes, já demonstra que a escrita de Sor privilegia outros aspectos, se comparados à versão de Giuliani que acabamos de examinar (esclareceremos tais diferenças adiante). A primeira variação de Sor introduz um traço característico de muitas obras deste compositor, que é o ritmo de marcha militar, com uma harmonização que explora mais a escrita coral, sempre distribuída com perfeição nas conduções internas. A próxima variação introduz uma idéia polifônica (a três vozes) de terças paralelas que dialoga com a voz superior ou com a linha grave. A terceira variação está disposta em acordes rebatidos, também a três vozes e com acordes em movimentos contrários. A última variação, ao contrário de ser virtuosística, é uma elegante barcarola a três vozes, com perguntas e respostas em estilo imitativo.

O violonista espanhol introduz um finale (ou "anti-finale") em forma de minueto, o que definitivamente afasta da obra qualquer pretensão de exibição técnica, em favor de uma exposição musical mais sofisticada. A forma utilizada é inclusive a mesma do minueto barroco, com duas seções em ritornello, evocando inequivocadamente o ethos do antigo regime, cuja simpatia de Sor é discutida por alguns autores ${ }^{34}$. Sor, embora já tenha escrito algumas obras virtuosísticas, como as Variações sobre um tema de Mozart, Op.9, prefere caminhar na contramão dos efeitos fáceis tão apreciados pelo público e pelos guitarristas de sua época. Sua música, de maneira geral, destinava-se a um público mais aristocrático e refinado, o que rendeu-lhe inclusive o apelido de "Beethoven da guitarra"35.

\footnotetext{
${ }^{34}$ Cf. DUDEQUE, Op.cit., p.63.

${ }^{35}$ PELLEGRIN, 2006, p.178.
} 


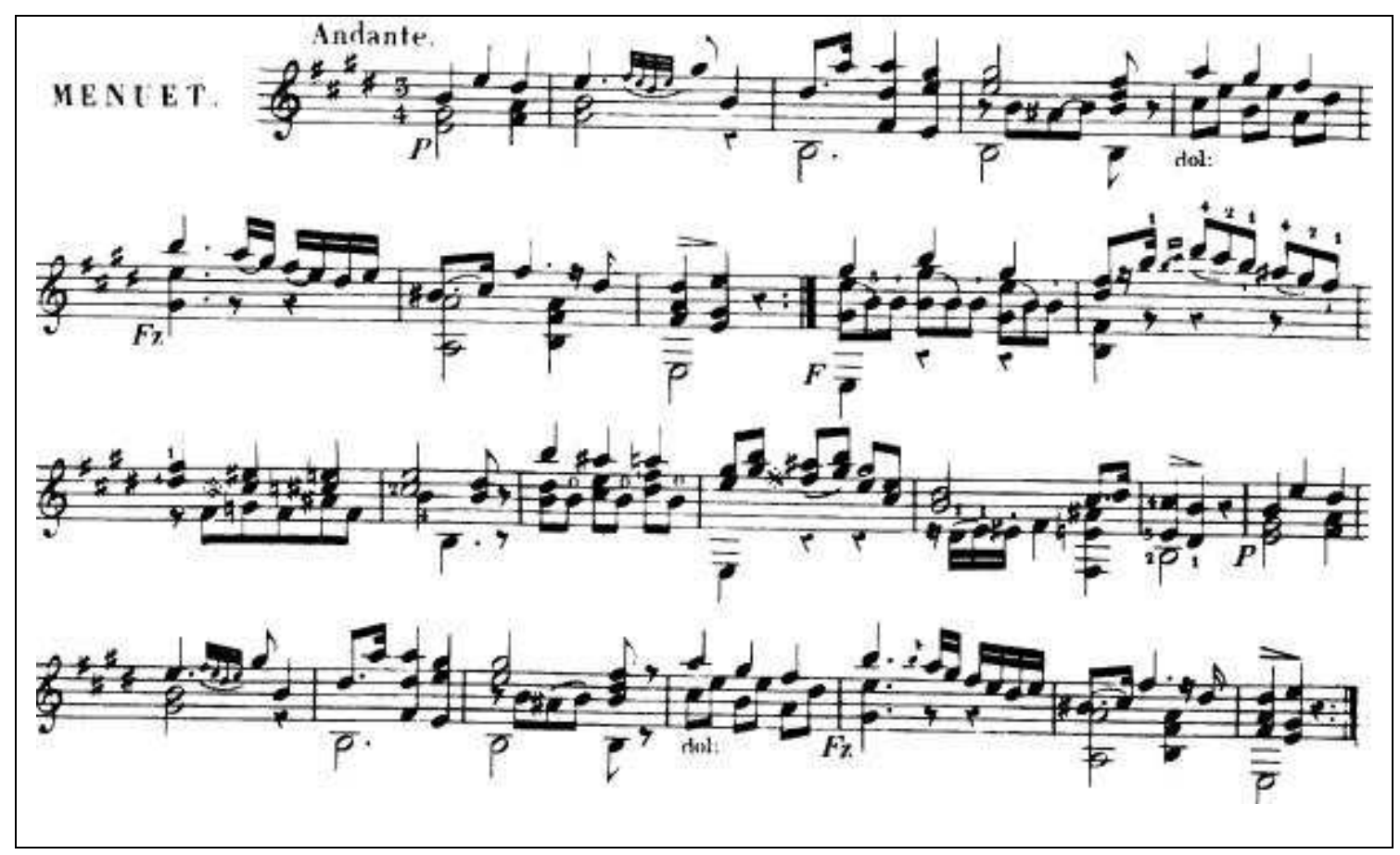

Fig.3.12: Sor: Folies d'Espagne (1815), minueto

A comparação entre as questões técnico-musicais nestas duas versões das variações sobre a Folias de Espanha somente reforçam a grande diferença estética na linguagem instrumental entre Giuliani e Sor, que por sua vez sintetiza a própria filosofia das escolas italiana e espanhola, em geral, da época de ouro da guitarra romântica. 


\begin{tabular}{|l|l|l|}
\hline \multicolumn{1}{|c|}{ SOR Op.15/1 } & \multicolumn{1}{|c|}{ GIULIANI Op.45 } \\
\hline Tema & Andante (coral a 3 vozes) & Andantino (contraponto 2 vozes) \\
\hline I & Marcha (terças a 3 vozes) & Imitação (2 vozes) \\
\hline II & Contraponto (terças a 3 vozes) & Spinning (2 vozes) \\
\hline III & Acordes rebatidos (terças 3 vozes) & Acordes (tercinas) \\
\hline IV & Barcarola (tercinas a 3 vozes) & Oitavas (eco) \\
\hline V & & Cantabile (tom maior, a 2 vozes) \\
\hline VI & --- & Militar (3 vozes, stacatto) \\
\hline Coda & Minueto (tom maior: AABBA) & Finale (tom maior: pedal-acordes-arpejos) \\
\hline
\end{tabular}

Tab.3.2: Comparação dos perfis de variações entre as versões da Folias de Espanha de Sor e Giuliani.

Este fato é claramente manifestado nos escritos de Sor. Na longa conclusão do seu famoso método, o guitarrista catalão elogia, ironicamente, o estilo abertamente virtuosístico de seu colega Giuliani:

Antes de executar o Trio de Hummel sobre 'a Sentinela' com os Srs.Hertz [Herz no original] e Lafont, fui obrigado a fazer a variação de guitarra Ex. 88, porque aquela encontrada no trio apresenta dificuldades muito maiores que a minha. A partir desta confissão, pode-se ver que se o gênero peculiar à guitarra é o da variação em questão, não sou tão habilidoso no instrumento quanto quem a escreveu. Eu poderia tocá-la, mas à custa de princípios dos quais não quero jamais distanciar-me. (SOR apud CAMARGO, 2005, p. 143, tradução de Guilherme de Camargo). ${ }^{36}$

\footnotetext{
${ }^{36}$ No original: "Devant jouer avec MM. Hertz et Lafont le trio de Hummel sur la Sentinelle, j’ai été obligé de me faire la variation de guitarre Ex.88, parceque celle qui s'y trouve m'offrait des difficultés bien plus grandes que la mienne. D'après cet aveu, on peut voir que si le genre péculier à la guitarre est celui de la variation em question, je ne suis pas si fort sur cet instrument que celui qui l'a écrite. Je pourrais l'exécuter, mais ce serait aux dépens des principles dont je ne voudrais me départir jamais.”
} 


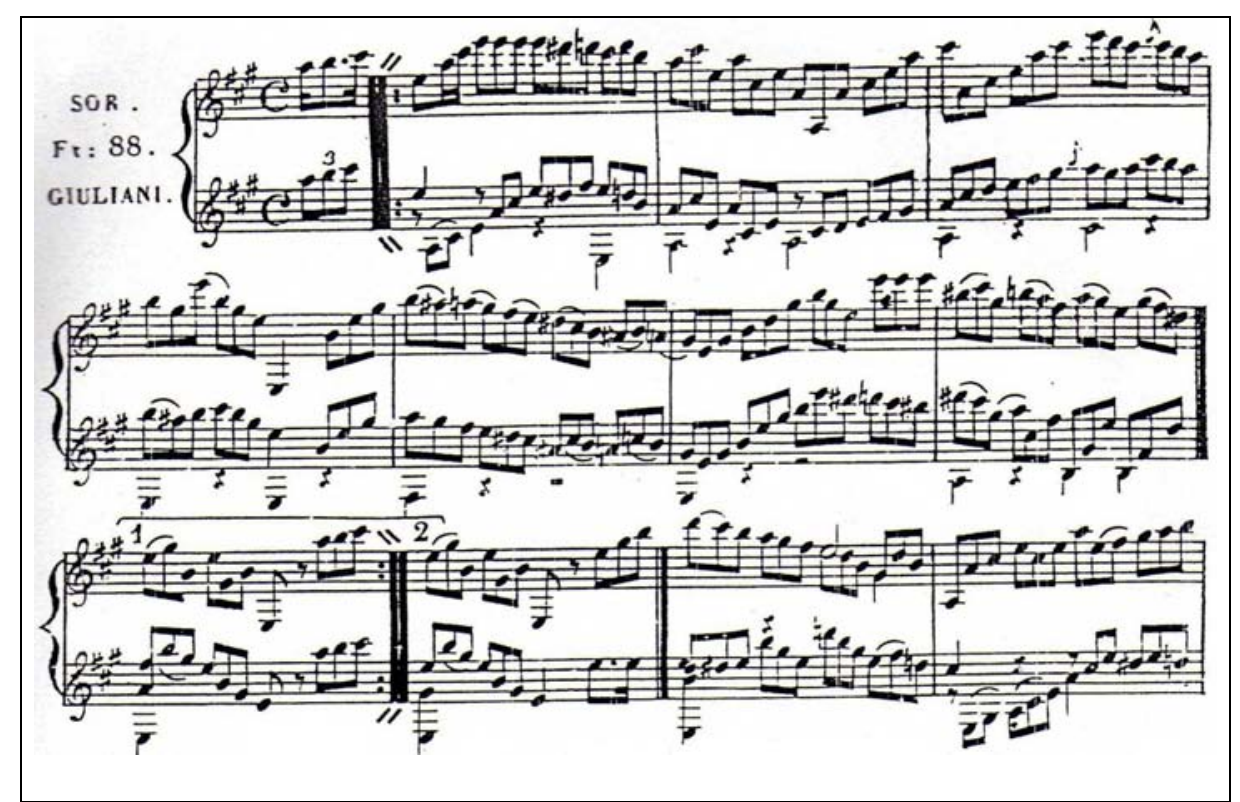

Fig.3.13: Exemplo 88 do Método de Sor, comparando as duas versões das variações sobre La Sentinelle, de Hummel, conforme a realização de Giuliani (pauta inferior) e Sor (pauta superior).

A comparação entre duas versões da mesma peça, um caso único na história do violão, demonstra duas maneiras distintas de abordar o mesmo problema musical. O que é surpreendente nesta comparação é que as duas realizações, embora totalmente diferentes entre si, são perfeitamente idiomáticas.

Os "princípios" mencionados por Sor, dos quais ele nunca se desviaria, podem ser identificados na disposição do arranjo que elimina as linhas de baixo e favorece o dedilhado fluente sobre os dedos polegar e indicador, à maneira dos antigos alaudistas ${ }^{37}$. A fim de favorecer essa textura, Sor procura minimizar a necessidade de uso dos dedos indicador e médio através do uso extensivo de ligados, determinando a preferência pelo uso de figurações que possam ser executadas em apenas uma corda ${ }^{38}$. A concepção de dedilhado de Giuliani, por outro lado, encarrega o polegar com a tarefa de conduzir a linha dos baixos deixando os demais dedos livres para manejar as passagens rápidas na região aguda com

\footnotetext{
${ }^{37}$ HECK, 1995, p.158.

${ }^{38}$ MICHELI, 2003, p.60.
} 
fórmulas alternadas, gerando um efeito mais "pirotécnico"39. Suas fórmulas de arpejos exploram ao máximo as constantes e rápidas mudanças de posição, o que, na opinião de Sor provocava vertigens, além de serem desnecessárias ${ }^{40}$.

Em relação ao uso de fórmulas de arpejos, Sor desaprovava o uso contínuo dos dedos indicador e médio, conforme exposto na segunda parte do seu Método:

Em geral, tudo a que se chama bateria [baixos de Alberti], se não representa qualquer outra coisa senão a si mesma, produziu-me sempre o efeito de um rodar contínuo cuja monotonia é insuportável. (SOR apud CAMARGO, 2005, p. 47, tradução de Guilherme de Camargo). ${ }^{41}$

O autor limita o uso de fórmulas de acordo com as poucas necessidades de sua própria música:

[...] só apresento aqui os meios que levam a tocar como eu, e porque combinações como aquelas do exemplo vigésimo terceiro afastam desse objetivo, ao invés de aproximar. A razão é que não só eu precisaria ter empregado o dedo anular, mas com muita frequencia ele seria obrigado (sendo o mais fraco) a marcar as notas acentuadas. (SOR apud CAMARGO, 2005, p. 4546 , tradução de Guilherme de Camargo). ${ }^{42}$

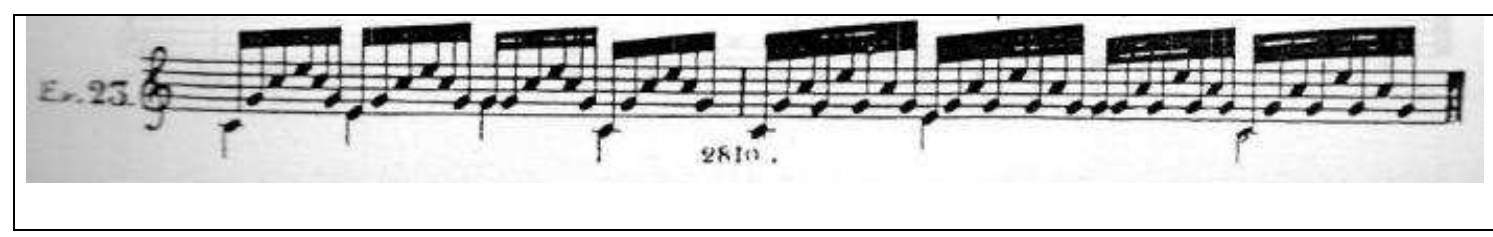

Fig.3.14: Exemplo 23 do Método de Sor.

\footnotetext{
${ }^{39}$ HECK, Op.cit., p.158.

${ }^{40}$ MICHELI, Op.cit., loc.cit.

${ }^{41}$ No original: "En général tout ce que l'on appelle batterie, si elle ne représente quelque autre chose qu'ellemême, m'a toujours produit l'effet d'un roulement continuel dont la monotonie est insupportable."

${ }^{42}$ No original: "Je ne présente ici que les moyens qui conduisent à jouer comme moi des combinaisons comme celles de l'exemple vingt-troisième em éloignent au lieu d'en approcher. La raison en est non seulement il m'aurait fallu employer le quatrième doigt, mais très souvent il aurait été obligé (lui étant le plus faible) de marquer les parties acentuées."
} 
Os exemplos "monótonos", utilizadas por praticamente todos os guitarristas compositores do início do século XIX, nada mais são do que as próprias fórmulas de arpejos números 31 e 83 dos 120 Arpejos Op.1 de Mauro Giuliani:

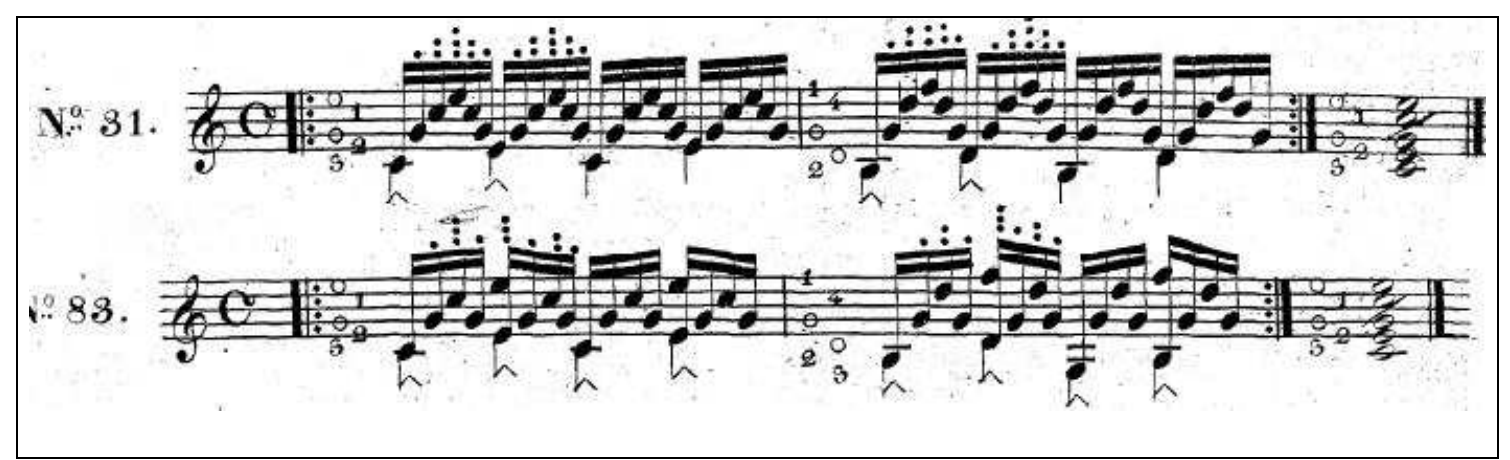

Fig.3.15: Giuliani: 120 Arpejos Op.1, Ns.31 e 83

Dez anos mais tarde, uma outra edição parisiense trouxe ao público uma nova versão das Folias de Espanha, desta vez de autoria de um compositor menos famoso, François de Fossa (1775-1849), que foi soldado do exército francês e guitarrista. Filho de um jurista da nobreza, combateu no México e na Espanha, onde foi capturado pelas tropas napoleônicas. Retornou à França em 1814, após a derrota das tropas francesas pelo exército inglês. Deixou a carreira militar em 1844 e instalou-se em Paris, onde morreu em 1849.

Sua obra começou a ser resgatada e publicada no ínicio dos anos 1980, revelando um compositor que conhecia profundamente a linguagem idiomática da guitarra. Fossa também foi responsável pela preservação em manuscritos dos quintetos com guitarra de Luigi Boccherini (1743-1805) e pela tradução francesa do famoso método de Dionísio Aguado.

De maneira geral, as variações de Fossa exigem um preparo técnico superior às duas versões anteriores de Sor e Giuliani, entretanto seu estilo composicional é herdeiro do estilo 
de Fernando Sor, incluindo as texturas a três e quatro vozes, o desinteresse pelo efeito fácil e as recorrentes citações de marchas militares.

Um dos elementos que salta à vista ao examinar a partitura de Fossa são as indicações detalhadas do metrônomo de Maelzel. Isso ocorreu devido ao fato de que o aparelho, embora tenha sido inventado muito tempo antes, estava sendo divulgado como uma grande novidade no universo musical, obtendo inclusive a aprovação de músicos como Beethoven e Berlioz.

$\mathrm{O}$ conjunto de seis variações, que recebeu o pomposo título Cinquième fantaisie pour la guitare seule sur l'air des Folies d'Espagne Opus 12, pode ser considerado como o "canto do cisne" de toda uma tradição que estava em processo de extinção com o final do romantismo, o que por pouco não fez a Folias de Espanha desaparecer por completo.

Após uma introdução em estilo de abertura operística e explorando os timbres dos sons harmônicos sobre uma nota ré pedal, o tema é apresentado em forma de hino militar revolucionário, em um movimento agitado em sextas paralelas, contrastando com a estaticidade da introdução: 


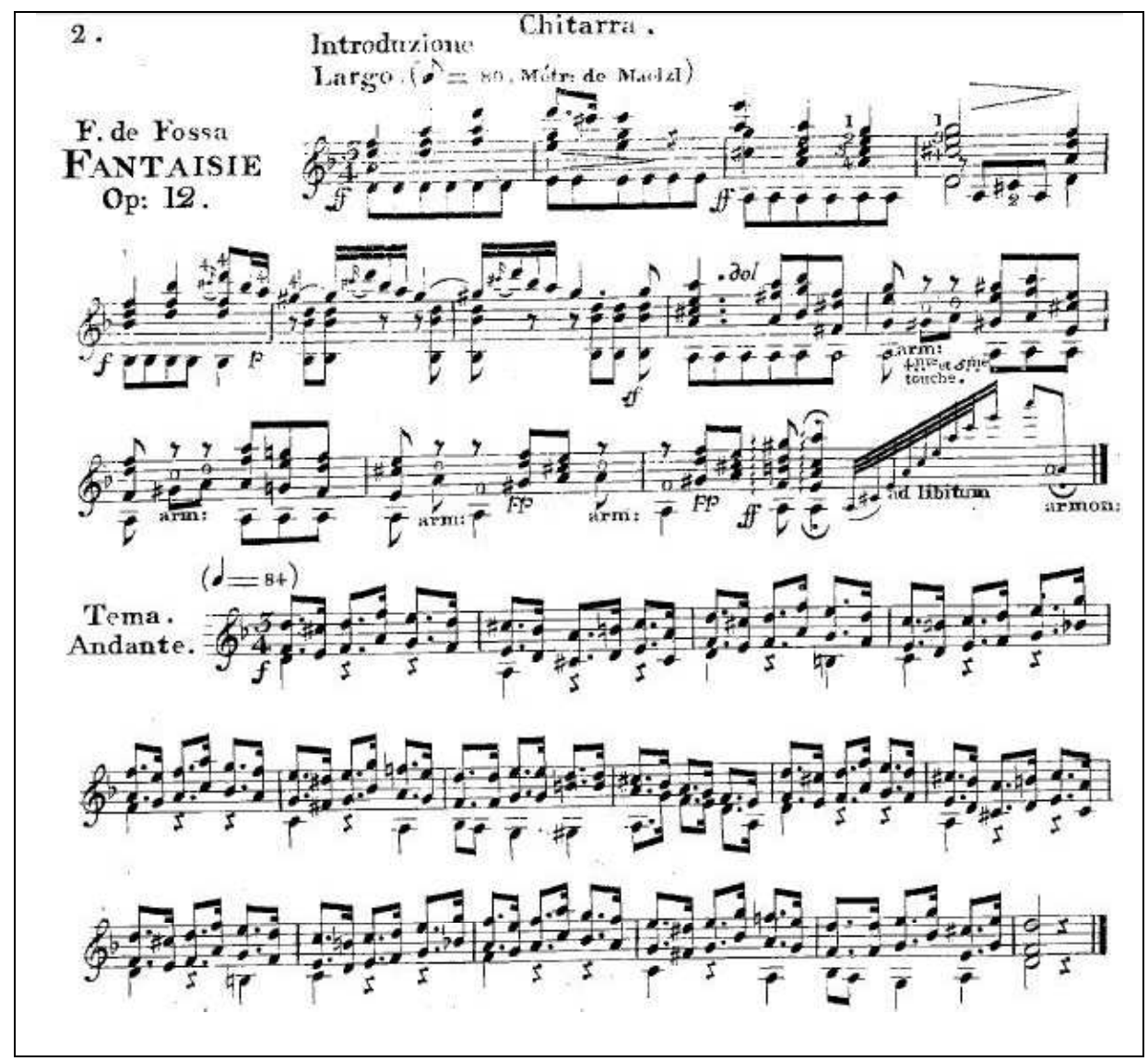

Fig.3.16: Fossa, Cinquième fantaisie (1825), introdução e tema

A variação I é em estilo imitativo a três vozes, alternando os intervalos de terças com os de sextas, para prosseguir na segunda variação em campanelas - cujo movimento contínuo possui forte semelhança com a segunda variação de Giuliani. A variação seguinte é uma imitação a três vozes, cujos diálogos entre os registros agudo e grave são travados a partir dos intervalos também alternados entre terças e sextas. A quarta variação é também semelhante à III de Giuliani, em arpejos rápidos na região aguda. A variação V também possui uma textura de arpejos, porém mais assemelhada ao tipo de figuração de Sor, remetendo à variação IV das Variações sobre um tema de Mozart Op.9: 


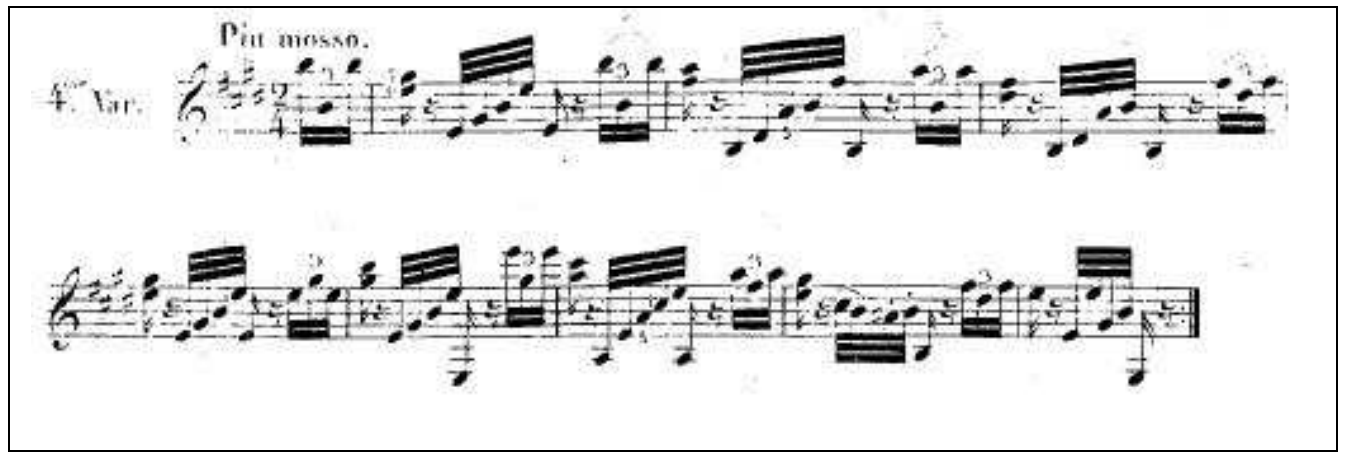

3.17: Sor, Variações sobre um tema de Mozart Op.9, variação IV

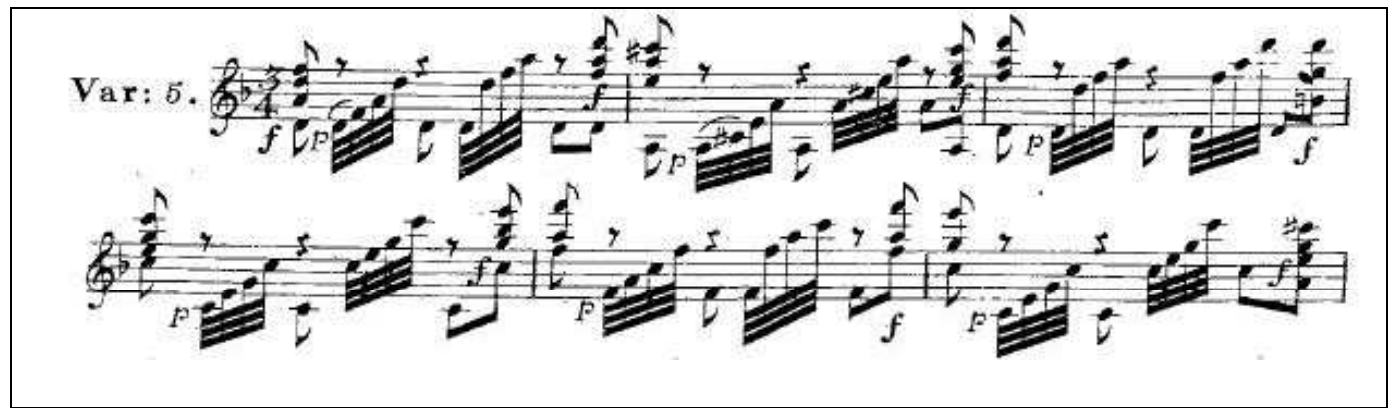

3.18: Fossa, Cinquième fantaisie (1825), variação V

A última variação é de rápidos arpejos de mão direita, numa abordagem mais virtuosística que evidencia um curioso padrão: a alternância entre os estilos de Giuliani e Sor. Essa hipótese se confirma com o anticlímax, com precedência no Op.15/1 de Sor, da coda final, conduzindo a conclusão da obra em acordes pianíssimos e delicados harmônicos. Dessa forma, esta breve análise nos indicou que era muito plausível que François de Fossa conhecesse bem as versões da Folias de Espanha de Giuliani e de Sor e tivesse feito de ambas o modelo para a elaboração de suas variações. 


\subsection{Alguns ecos da tradição no Romantismo}

A estética romântica, em sua busca pela maior liberdade formal e pela expressão mais intensa e vigorosa das emoções, trouxe inovações que mudaram o cenário musical do século XIX. As harmonias tornam-se mais ricas, com maior emprego de dissonâncias. Se por um lado houve um rico florescimento do lied e das pequenas formas - valsas, romances, canções sem palavras, prelúdios, estudos, etc., por outro o gênero sinfônico cultivou a preferência pelos grandes conjuntos sinfônicos e corais e pelas grandes massas sonoras. A orquestra cresceu não só em tamanho, mas também em variedade. O gênero sinfônico caminhava ao lado da crescente popularidade dos virtuoses do piano e do violino, e o concerto romântico também adquiriu proporções transcendentais.

O gênero Tema e Variações sobre um tema de outro autor previamente escolhido foi praticamente abolido no início do século XIX. Até mesmo o título "Variações sobre um tema de ...” era depreciado, tendo sido substituído por tendências nacionalistas mais atraentes do ponto de vista comercial (variações sobre temas russos, eslavos, etc.). Beethoven reabilitou a historicidade do gênero, mas usando em geral o recurso da escrita para grupos camerísticos a fim de preservá-la de preconceitos, enquanto Johannes Brahms (1833-1897) resgatou-a mais ostensivamente em seu repertório para piano ${ }^{43}$.

Além disso, se levarmos em consideração o fato de que os compositores da "Época de Ouro" da guitarra romântica adotaram uma estética composicional anacrônica, baseada nos procedimentos formais e harmônicos da linguagem mozartiana do classicismo vienense (portanto quase um universo à parte), é possível afirmar que a Folias de Espanha, em seu formato Tema e Variações, ficou adormecida por um período de aproximadamente 80 anos,

\footnotetext{
${ }^{43}$ LITTLEWOOD, 2004, p.30.
} 
com as variações de Carl Phillip Emmanuel Bach como último compositor de uma corrente centenária.

Brahms foi também o compositor que reacendeu a chama das variações sobre a Folias de Espanha em 1860, com o segundo movimento (Andante, ma moderato) do Sextuor a cordes No. 1 em Si bemól maior, Opus 18 - também conhecido como Frühlingssextett (Sexteto da Primavera). Brahms realizou uma versão para piano solo do segundo movimento - que seria publicada apenas em 1927 sob o título genérico de "Tema com Variações" ${ }^{44}$ - que foi presentada a Clara Schumann (1819-1896) em seu aniversário no ano de $1860^{45}$.

Brahms apreciava particularmente a forma Tema e Variações, por ser um meio que lhe permitia combinar disciplina e imaginação ${ }^{46}$. Além disso, ele prestou diversas homenagens aos grandes mestres utilizando essa mesma forma, como as Variações sobre um tema de Robert Schumann Op.9, Variações sobre um tema de Haendel Op.24, Variações sobre um tema de Paganini Op.35, Variações sobre um tema de Haydn Op.56a. Brahms assimila tão bem o espírito e a estética desses compositores que suas variações resultaram numa particularidade estésica, dando a impressão de que o autor homenageado poderia estar improvisando sobre um tema do próprio Brahms, o que gerou uma espécie de "duplicidade autoral”, e vice-versa, como se Brahms fosse momentaneamente tomado pela idiossincrasia do outro.

Sempre que Brahms escrevia sobre os princípios básicos da composição, ele valorizava as velhas técnicas em detrimentos das novas e recomendava fidelidade à melodia

\footnotetext{
${ }^{44}$ Talvez a publicação tardia dessa versão para piano possa ter contribuído para que Rachmaninoff escrevesse suas variações sobre a Folias de Espanha, em 1930.

${ }^{45}$ KOREVAAR, 2004, p. 10.

${ }^{46}$ KELLER, 1982.
} 
do tema nas variações. Entretanto, sua obra contrariava muitas vezes seus próprios enunciados teóricos, especialmente no que se refere ao tratamento inovador de suas conduções de baixo baseadas em inversões, que ampliou os próprios cânones da escrita clássica. Seu poético aforisma sobre o tema no baixo como uma "firme fundação" sobre a qual ele "construía estórias" revela sua dupla faceta de arquiteto e contador de estórias, infundindo em cada edifício um espírito vivo ${ }^{47}$.

Ao longo de sua trajetória criativa, Brahms buscava o perfeito equilíbrio entre as facetas emocional e intelectual de sua música, e seus conjuntos de variações refletem bem essa busca em direção a uma perspectiva mais "clássica" e racionalista: enquanto as primeiras obras demonstram um ímpeto mais passional, com ocasionais desvios da estrutura temática - como no Opus 9 - encontramos em obras tardias uma total aderência ao perfil temático - vide o Opus $56 \mathrm{a}^{48}$.

O Sexteto N.1 é considerado como a obra camerística mais acessível de Brahms, por sua qualidade "neoclássica" lisztiano combatido por Brahms e seu colega, o violinista Joseph Joachim (1831-1907). Este lamentava, em um manifesto publicado em 1859, a respeito da:

[...] influência malígna exorcizada pelos 'Novos Alemães' que, em sua vaidade e arrogância, consideram tudo que foi criado até agora do grande e sagrado talento musical de nosso povo como mero fertilizante para as sementes indecentes e miseráveis que brotam das fantasias lizstianas. (JOACHIM apud KOREVAAR, 2004 , p.9, tradução nossa). ${ }^{50}$

\footnotetext{
${ }^{47}$ SISMAN, 1990, p.153.

${ }^{48}$ KOREVAAR, 2004, p.7.

${ }^{49}$ MUSGRAVE, 1994, p.90.

${ }^{50}$ No original: "the evil influence exercised by the 'New Germans' who, in their vanity and arrogance, regard everything great and sacred which the musical talent of our people has created up to now as mere fertilizer for the rank, miserable weeds growing from Liszt-like fantasias.”
} 
É possível que o uso do tema Folias de Espanha no segundo movimento tenha sido uma escolha consciente, no sentido de olhar para o passado e buscar nele elementos para um novo revigoramento estético, sem apelar para os novos recursos das harmonias cromáticas wagnerianas e das formas programáticas lisztianas. O tratamento do tema ostenta a dignidade de um coral luterano ${ }^{51}$ :

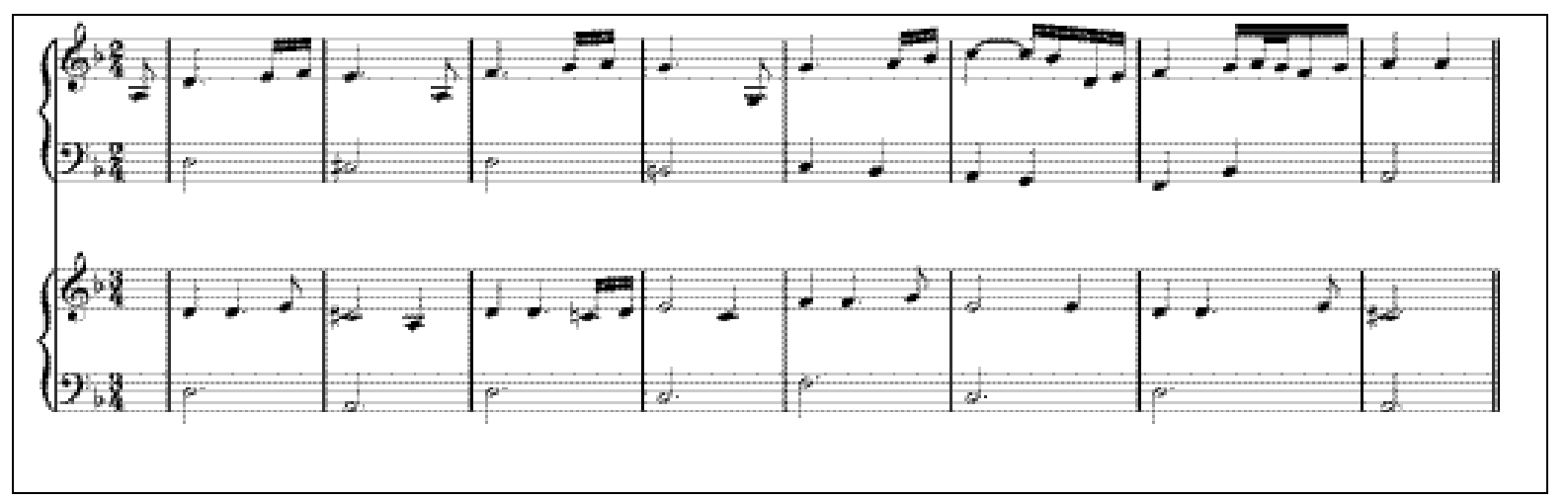

Fig.3.19: Tema do Andante, ma moderato do Sexteto N.1 Op.18 de Brahms, comparado com o tema Folias de Espanha.

A citação da Folias de Espanha está parcialmente transmutada: se por um lado temos um afastamento ocasionado pelo tempo binário ao invés do tradicional ternário, por outro há uma referência à tradição pela simulação de um acompanhamento guitarrístico nas cordas. Existem vários recursos arcaicos no Andante (como o típico interligamento das variações barrocas, as articulações e as ornamentações que aludem às práticas antigas) ao lado de gestos tipicamente românticos (como as amplas melodias, repetições com harmonias enriquecidas e os contrastes de texturas, que oscilam entre a delicadeza intimista e a saturação massiva). Na segunda parte do tema (compassos 17-36), a emergência das harmonias cromáticas aumentam a intensidade, formando um grande arco que conduz ao clímax na cadência final (compasso 36$)^{52}$.

\footnotetext{
${ }^{51}$ KELLER, op.cit.

${ }^{52}$ LITTLEWOOD, op.cit, p.146.
} 
As seis variações que se seguem colocam em cena dualidades como arcaísmo versus romantismo, afastamento versus proximidade do tema, texturas camerísticas versus sinfônicas. Observamos que, desde a apresentação do tema, há uma aceleração rítmica que acompanha o afastamento gradual da melodia geradora, em uma subdivisão do pulso rigorosamente ordenada e cada vez mais dinâmica ${ }^{53}$ :

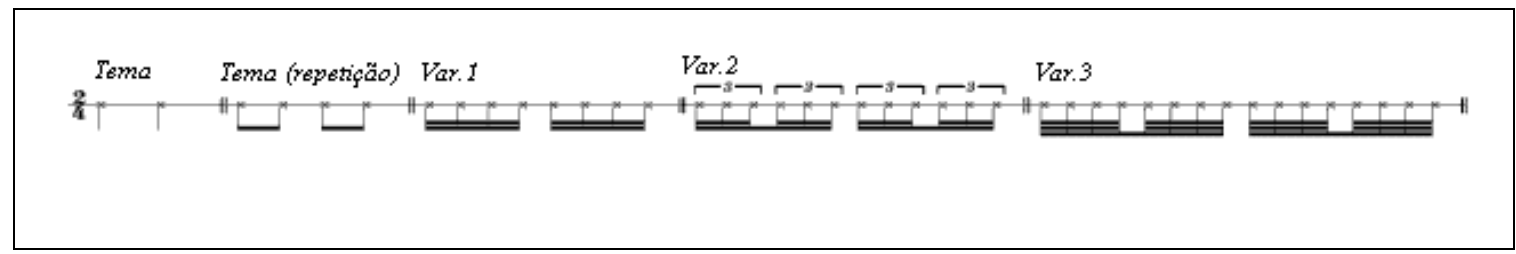

Fig.3.20: Aceleração rítmica controlada do tema até a Variação 3.

Tal projeção rítmica em grande escala conduzindo o afastamento remete a uma percepção temporal diferenciada, dentro do conceito de "duração pela razão" formulado por Gaston Bachelard (1884-1962), em que “[...] longe de os ritmos serem necessariamente fundados numa base temporal bem uniforme e regular, os fenômenos da duração [...] são construídos com ritmos" $" 54$.

Para Brahms, o papel da linha de baixo é fundamental para controlar a estrutura e o caráter de cada variação individualmente e de todo o conjunto. Ele afirmava que para criar algo novo e descobrir novas possibilidades melódicas, era necessário confiar ao baixo um papel ao mesmo tempo passivo e ativo. Enquanto entidade passiva, o baixo não era considerado por Brahms como um tema, mas simplesmente a parte mais grave de uma textura. Assim, vemos como o compositor atribuía importância equivalente às partes agudas e graves em suas composições ${ }^{55}$. A primeira variação, por exemplo, parte do

\footnotetext{
${ }^{53}$ LITTLEWOOD, op.cit., p.147.

${ }^{54}$ BACHELARD apud SEINCMAN, 2001, p.126.

${ }^{55}$ SISMAN, 1990, p.135.
} 
registro grave descrevendo uma trajetória ascendente em arcos de duas oitavas no campo de tessitura em contrapontos imitativos que se intensificam à medida que a variação progride:

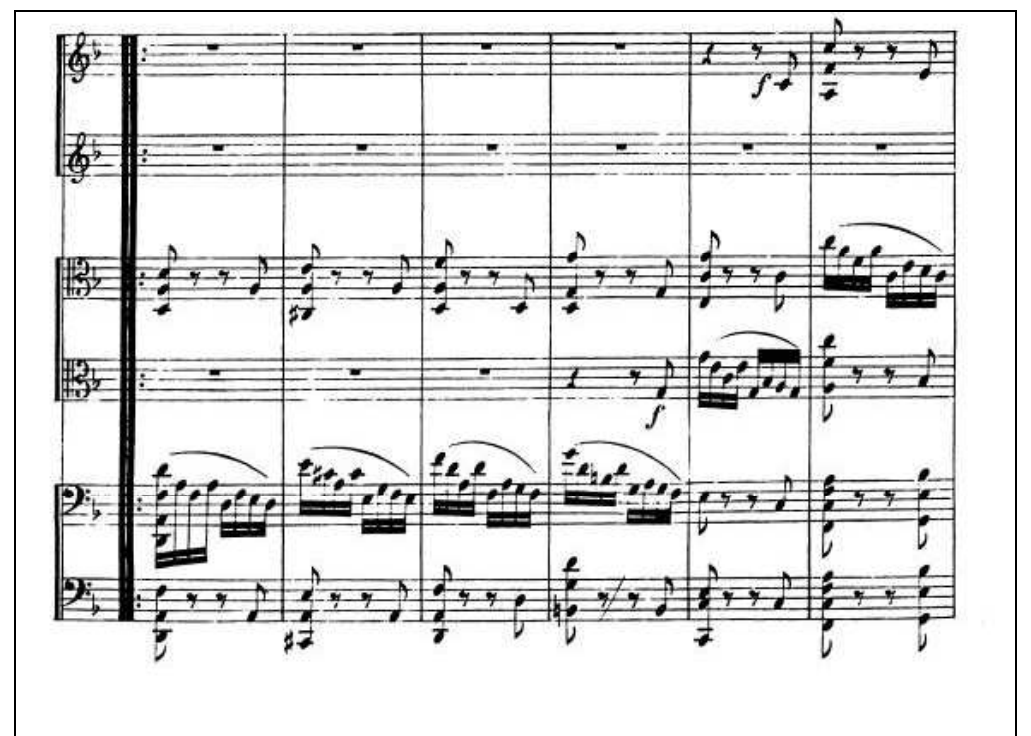

Fig.3.21: Variação I do Andante, ma moderato do Sexteto N.1 Op.18 de Brahms.

A segunda variação assume um caráter mais sutil e reforça o aspecto contrapontístico, desenvolvendo a técnica do cânone entre os violinos e violas. O ponto culminante sobre a nota dó (compasso 53, primeiro violino) é reforçado pela mudança de articulação para o legato, pela nova sonoridade ( $p$ dolce) e pela emergência de uma voz melódica interna, gerando um inesperado efeito dramático por estarem situadas no meio do curso de uma frase: 


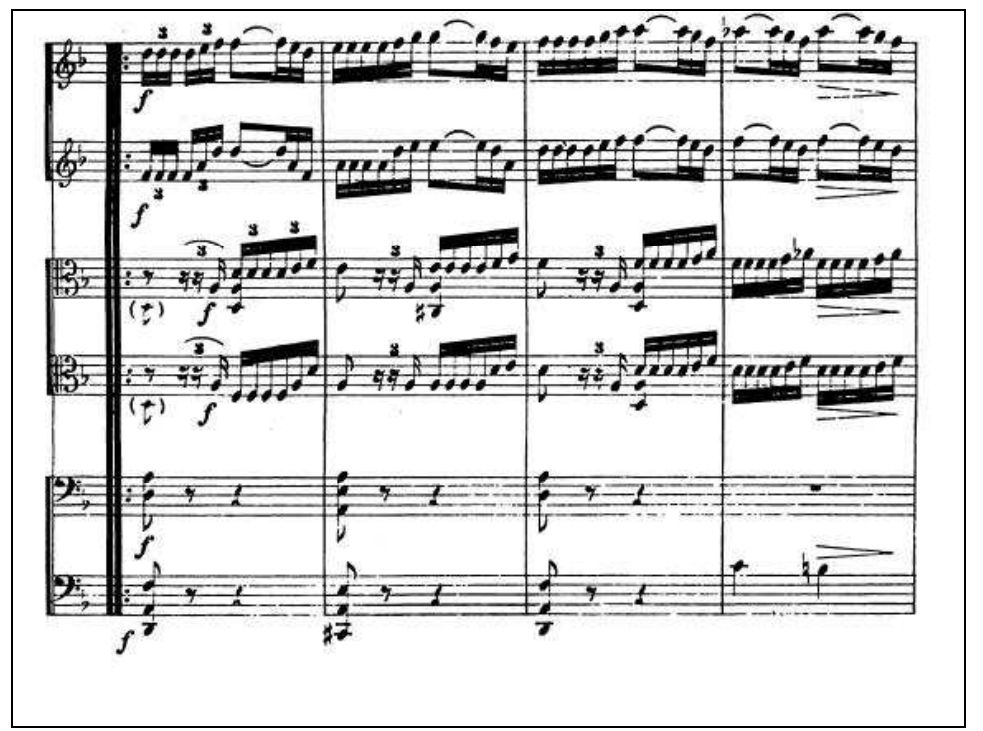

Fig.3.22: Variação II do Andante, ma moderato do Sexteto N.1 Op.18 de Brahms.

Esta é o primeiro momento em que as sonoridades suaves são apresentadas no movimento, mudando o foco da estabilidade barroca para um gesto mais intimista e romântico $^{56}$.

$\mathrm{Na}$ variação seguinte, Brahms afirma plenamente a ambientação burguesa do movimento que vinha sendo sugerida nas variações anteriores, apresentando agora um caráter mais sinfônico e dramático, afastando-se totalmente da idéia temática original em suas facetas mais extremas, uma vez que o tema original, reconhecível nas duas variações iniciais, ficou completamente dissolvido. Se antes estavam sendo explorados os aspectos referentes à superfície, desta vez a música convida a uma reflexão sobre a sua substância ${ }^{57}$. As mudanças de textura são bem mais radicais: o violoncelo desce uma oitava abaixo equiparando-se ao registro do contrabaixo; a fluidez e o floreamento das linhas em movimentos escalares sugerem um movimento ondulante quase glissando; as dinâmicas estão gradualmente mais intensas $(f$, più $f, f f \ldots)$ :

\footnotetext{
${ }^{56}$ LITTLEWOOD, Op.cit., p. 148.

${ }^{57}$ Id., ibid, loc.cit.
} 


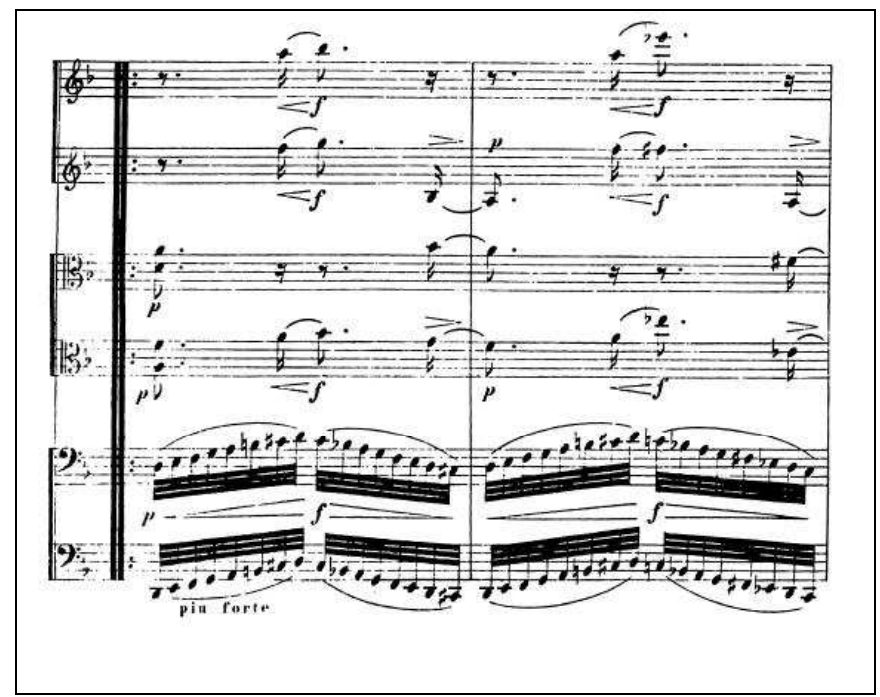

Fig.3.23: Variação III do Andante, ma moderato do Sexteto N.1 Op.18 de Brahms.

A variação IV é ambígua no sentido em que propõe simultanemente um novo afastamento - causado pela mudança ao modo maior - e um retorno ao ambiente barroco do tema. Os procedimentos antes mantidos, como o tom menor e a regularidade de pulsação rítmica são abandonados ao mesmo tempo em que são resgatados certos elementos descartados, como a ornamentção barroca, o plano dinâmico centrado nas intensidades fortes e o formato dos doubles com mudança de oitavas. Se por um lado o universo sinfônico da variação III foi abandonado, a austeridade do tema ainda é incompleta por certos recursos românticos: todas as partes contêm a indicação molto espressivo, amplos arcos de ligadura, e mais um ponto culminante tratado como um momento de relaxamento ao invés de intensificação: 


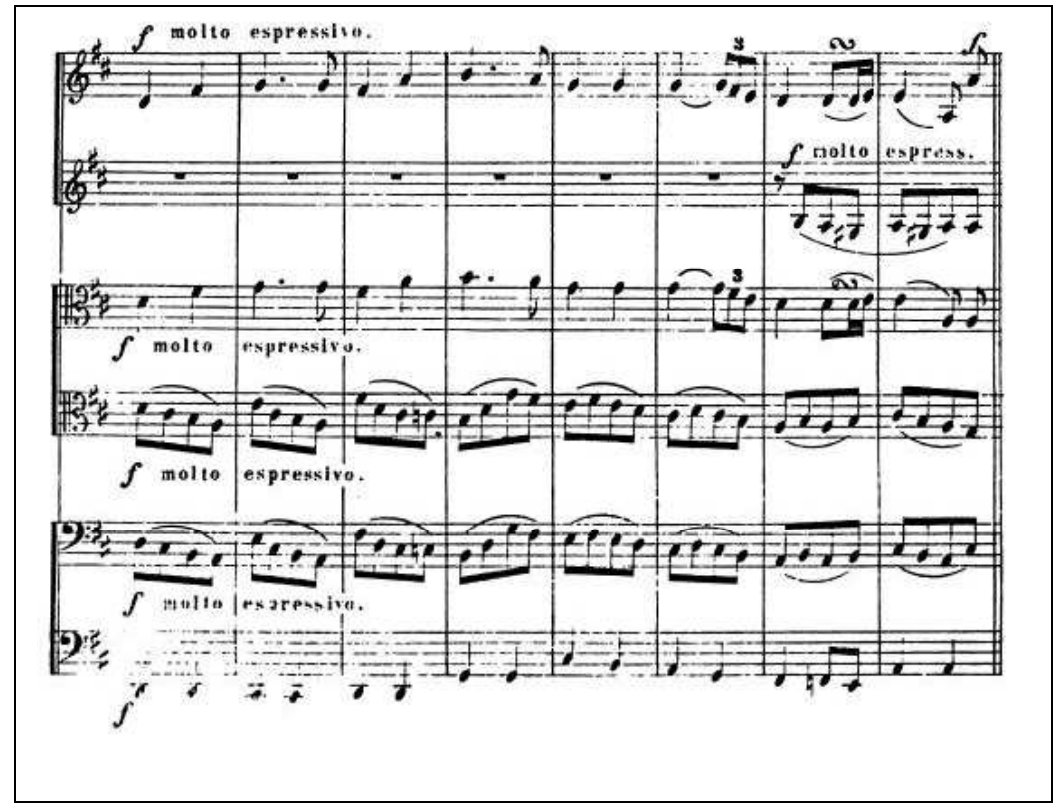

Fig.3.24: Variação IV do Andante, ma moderato do Sexteto N.1 Op.18 de Brahms.

A quinta variação do Andante possui uma contrastante atmosfera de recolhimento, ainda preservando o tom de Ré maior e alguns procedimentos da sessão que a antecede, mas com diferenças que reforçam o ambiente intimista: articulação em ligado dolce $p$ substituido o portato $p$, maior variedade melódica no acompanhamento e harmonização mais rica ${ }^{58}$. As variações IV e V em modo maior não teriam nada de especial se não fosse por um detalhe ambíguo: as três variações iniciais em modo menor evocaram um ethos antagônico ao seu caráter devido às texturas sinfônicas massivas, enquanto que a típica grandiosidade do modo maior nas variações IV e $\mathrm{V}$ foi convertida à delicadeza e à expressividade:

${ }^{58}$ LITTLEWOOD, Op.cit., p. 150. 


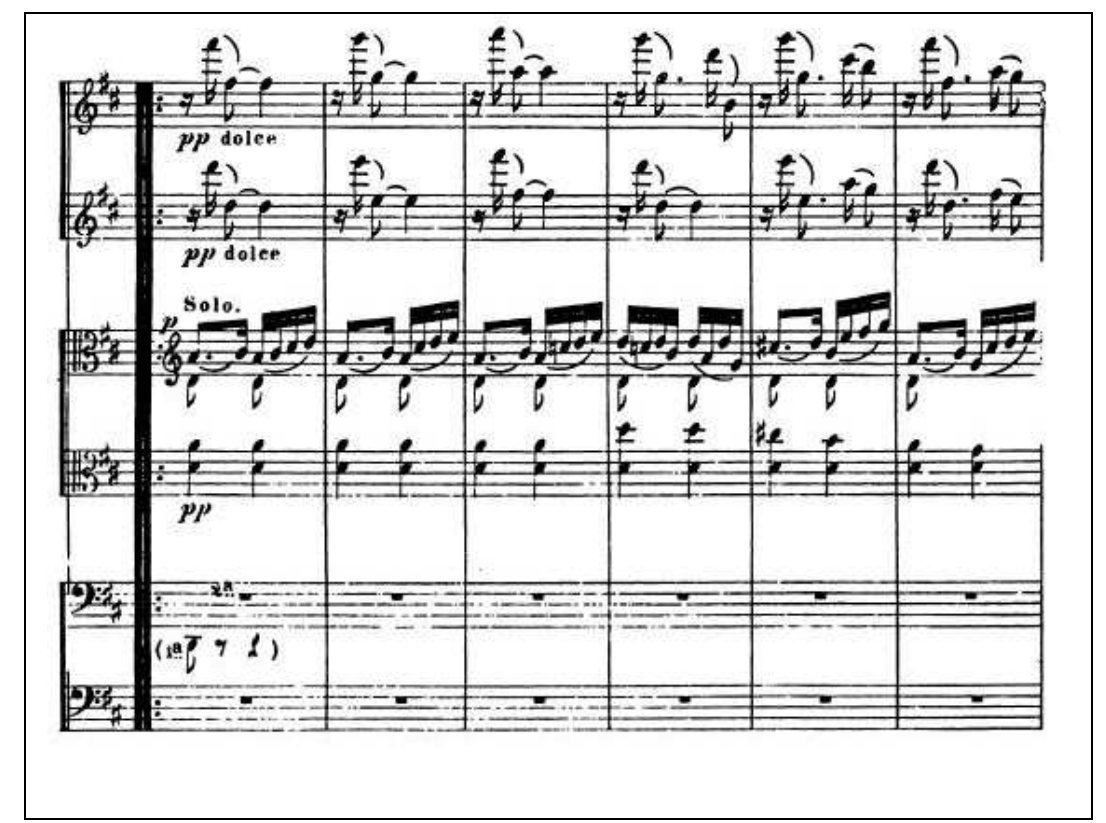

Fig.3.25: Variação V do Andante, ma moderato do Sexteto N.1 Op.18 de Brahms.

A última variação possui texturas transparentes, com muito espaços vazios e mais pausas do que quaisquer das anteriores, prenunciando a característica evanescente da sua coda.

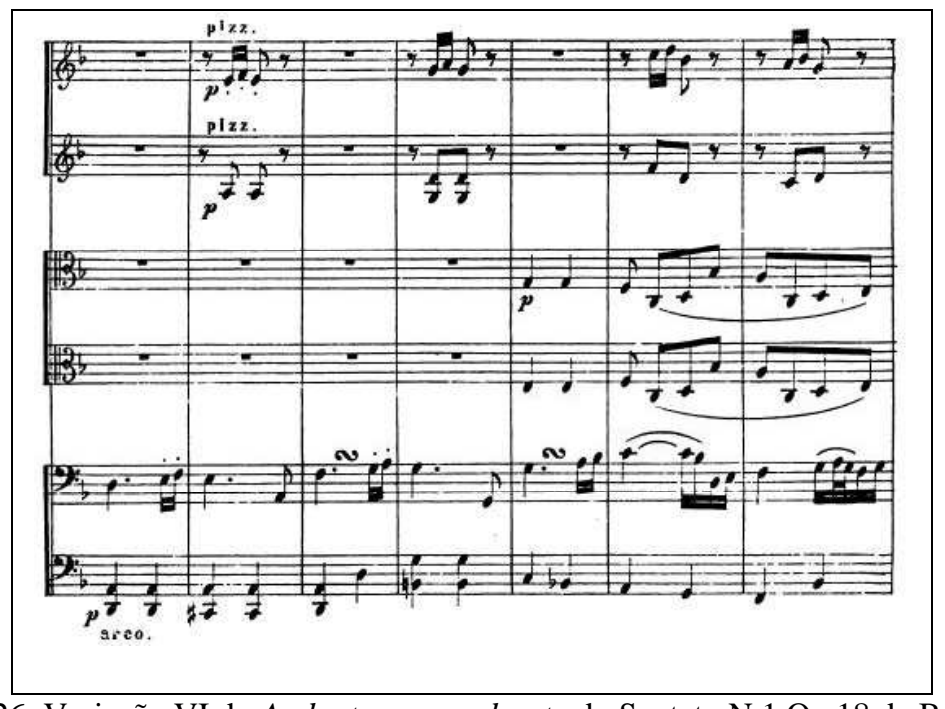

Fig.3.26: Variação VI do Andante, ma moderato do Sexteto N.1 Op.18 de Brahms. 
Após o retorno ao tom menor e ao tema, desta vez exposto direto sem o ritornello ou o double, a coda traz duetos em terças entre os pares de instrumentos, conduzindo novamente ao tom maior, com cada um dos instrumentos calando-se para terminar o movimento em absoluta serenidade.

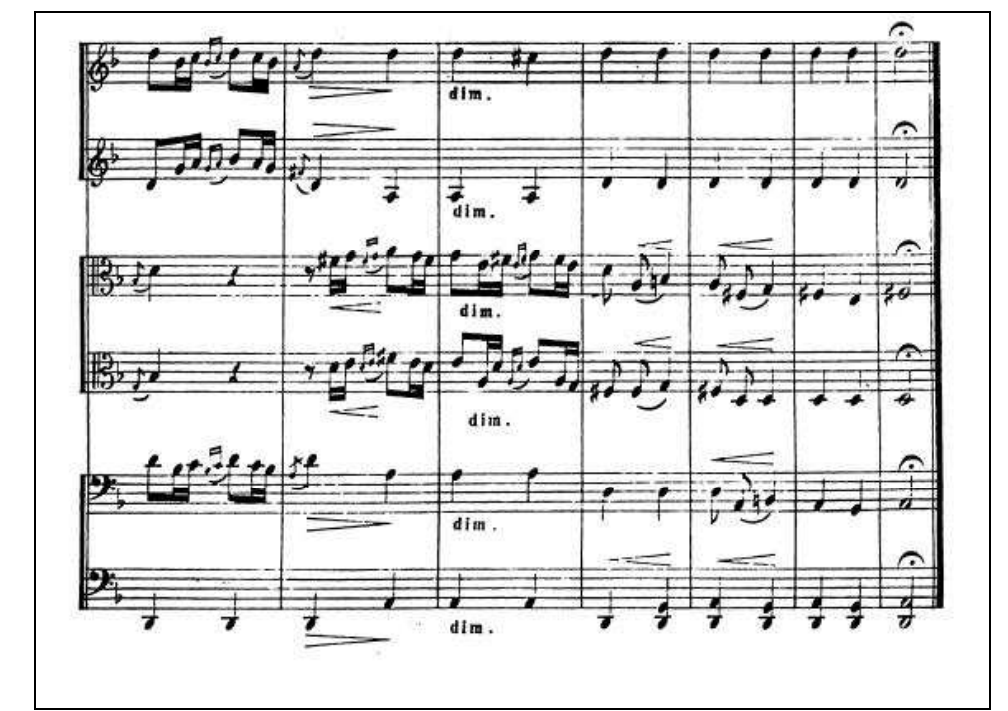

Fig.3.27: Coda do Andante, ma moderato do Sexteto N.1 Op.18 de Brahms.

O famoso pianista húngaro Franz Liszt (1811-1886) era um grande entusiasta da música e das danças folclóricas de toda a Europa, as quais foram utilizadas em muitas de suas próprias composições. Uma dessas inspirações resultou na peça Rapsódia Espanhola escrita em Roma, 1863, e publicada em 1867. É uma obra de exibição até hoje, especialmente na versão de Ferrucio Busoni (1866-1924) para piano e orquestra, de 1894, estreada em 1904 por Bela Bartók com regência do arranjador, em Manchester.

Apesar de Liszt ter sido o primeiro pianista virtuose a fazer uma turnê pela península ibérica, entre 1844 e 1845 , ele não ouviu o tema uma vez sequer nesta viagem, conforme relatou em carta de 1845 ao conde Felix von Lichnowsky: "como você sabe, [Folias de Espanha] é o nome de uma canção perfeitamente conhecida no exterior, mas que 
eu nunca ouvi enquanto estive na Espanha"59 . Não obstante, a experiência do contato com a cultura hispânica contribuiu fortemente para a composição da Rapsódia Espanhola, uma vez que o compositor relatou a Lina Ramann que a peça retrata suas recordações de viagem a Espanha ${ }^{60}$.

Apesar de ser hoje uma das obras mais conhecidas de Liszt, levou tempo para que fosse incorporada ao repertório pianístico. O fato que talvez tenha contribuído para isso é que ela foi publicada durante muito tempo ao lado da primeira das 15 Rapsódias Húngaras $^{61}$.

Sua estrutura é bastante simples, idêntica à das rapsódias húngaras: dois temas contrastantes em caráter seguidos de variações livres, com a diferença de que a lenta introdução (lassu) foi substituída pela Folias de Espanha em ares majestosos, e a dança rápida (friska) pela saltitante Jota Aragonesa ${ }^{62}$. Abrindo com uma das mais amplas e sofisticadas cadenzas de Liszt, a primeira sessão retoma a antiga faceta de solenenidade da Folias de Espanha, desta vez em Dó sustenido menor:

\footnotetext{
${ }^{59}$ LISZT apud STEVENSON, 1979, p.493. No original: "as you know, [folies d'Espagne] is the title of a song perfectly familiar abroad, but one that I never heard while in Spain”.

${ }^{60}$ HOWARD, 1997.

${ }^{61}$ Id., ibid.

${ }^{62}$ A Jota Aragonesa é uma melodia em forma de valsa, acompanhada por guitarras, castanholas e triângulos, trazida por um mouro de Valencia para Aragão no século XII. Permanece até hoje como uma das mais populares danças do norte da Espanha.
} 


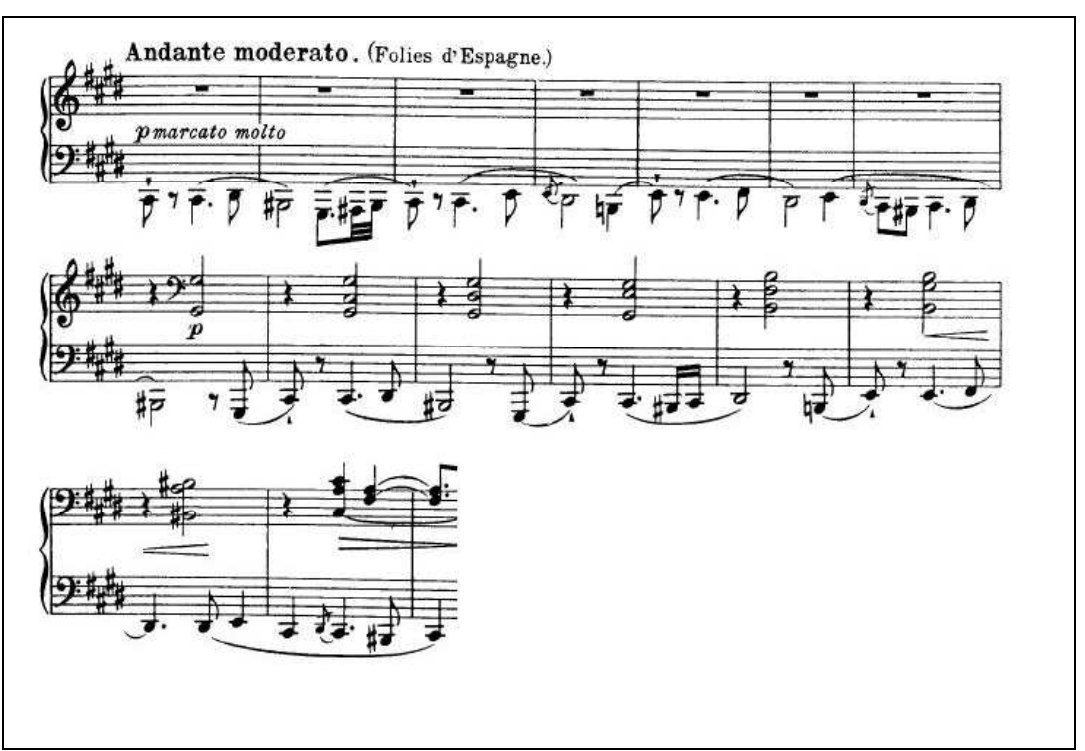

Fig.3.28: Introdução lenta da Rapsódia Espanola, de Liszt, baseada no tema Folias de Espanha.

O ambiente dramático da abertura, explorando a região grave do piano, combinado aos elegantes floreios, evocam as sonoridades da recém-composta peça Legende: St. François d'Assise: La predication aux oiseaux ${ }^{63}$. As variações que se seguem estão desenvolvidas sobra a forma da passacaglia barroca.

A última variação modula para o tom de Ré maior com um suave deslizamento que apresenta delicadamente o tema Jota Aragonesa na região aguda, inaugurando a segunda parte em contraste brilhante:

\footnotetext{
${ }^{63}$ HOWARD, Op.cit.
} 


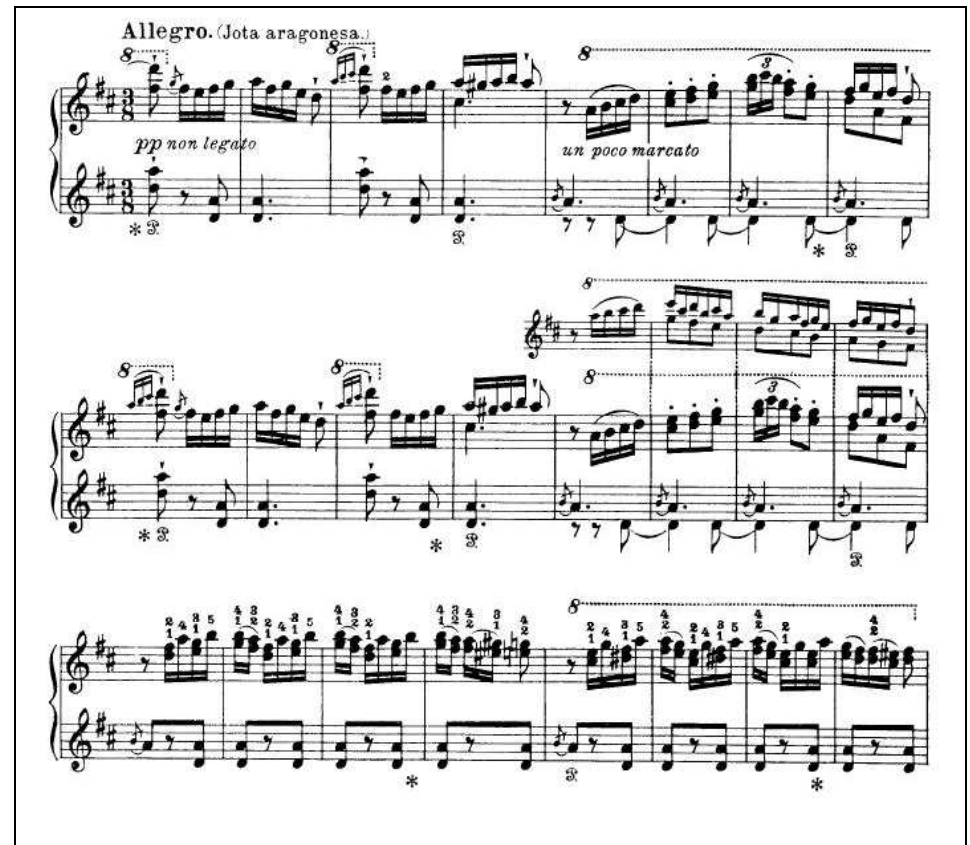

Fig.3.29: Apresentação do segundo tema Jota Aragonesa na Rapsódia Espanola, de Liszt.

A apresentação de um terceiro tema traz consigo uma série de modulações, para os tons de Fá maior, Lá bemól maior, Mi maior e Mi bemól maior, antes de retornar ao tom Ré maior que se reestabelece para a grande reprise da Jota e da Folias na conclusão da obra ${ }^{64}$.

Em geral, a estrutura da Rapsódia Espanhola é menos rapsódica que suas parceiras húngaras, e sua natureza expressiva é mais poética que pirotécnica, sendo necessário uma abordagem mais elegante e menos virtuosística na sua execução.

Uma outra obra de inspiração espanhola anterior a esta, a Grosse Konzertfantasie uber Spanische Weisen - ou simplesmente Fantasia Espanhola para piano, composta em Lisboa em 1845 e publicada postumamente, compartilha apenas o tema da Jota Aragonesa. As inovações da estrutura rapsódica e das colorações espanholas que Liszt criou nas duas peças, assimilando perfeitamente os temas ibéricos ao seu próprio estilo brilhante, abriram

\footnotetext{
${ }^{64}$ HOWARD, Op.cit.
} 
caminho para compositores futuros que também beberiam da fonte da cultura espanhola, como Nicolai Rimsky-Korsakov (1844-1908) e Maurice Ravel (1875-1937) ${ }^{65}$.

Um último eco da tradição em fins do século XIX aparece numa melodia folclórica arranjada em 1874 pelo compositor norueguês Edvard Grieg (1843-1907) no ciclo Melodias Norueguesas, (EG 108, N.25: I Rosenlund i Sagas Hal ${ }^{66}$ ). Desta vez a citação não traz nenhuma carga narrativa ou de historicidade, não obstante trata-se de uma coincidência que traz à tona um fato interessante relacionado ao itinerário da Folias de Espanha na Europa como cultura popular, chegando à Escandinávia.

Como vimos em capítulos anteriores ${ }^{67}$, a prática antiga de usar melodias alheias e o fenômeno da circularidade cultural disseminou a Folias de Espanha por todos os países da Europa. Os próprios músicos se espalharam pelo continente, acompanhando o séquito da nobreza e levando consigo o repertório de outros países. Desse modo, muitas melodias trazidas à Escandinávia a partir do século XVII são provenientes de países como Polônia, França, Espanha, etc. O resultado desse movimento é que muitas melodias do folclore escandinavo são idênticas a temas provenientes de outras nacionalidades, ou variantes deles. Algumas melodias estão preservadas e podem ser localizadas nos arquivos das cortes das cidades de Estocolmo, Upsala e Tronheim ${ }^{68}$.

Assim, não é de causar estranheza o fato de que a Folias de Espanha é uma das mais conhecidas melodias escandinavas, e é muito utilizada em baladas, canções folclóricas e cantigas de ninar. Na Finlândia e na Suécia ela aparece no formato de polska, com oito compassos adicionais. Existe uma versão dessa dança na Islândia, com a temática da

\footnotetext{
${ }^{65}$ STEVENSON, 1979, p.512.

${ }^{66}$ Em Rosenlund nos tempos dos contos de fadas.

${ }^{67} \mathrm{Cf}$. capítulos 1.2 à 1.7 .

${ }^{68}$ KIRTON, 2005, p.4.
} 
bebida $^{69}$, cuja versão finlandesa é intitulada Lampaan Polska ${ }^{70}$. No sul da Suécia há uma versão dessa mesma polca como Fiol i Spann ${ }^{71}$ :

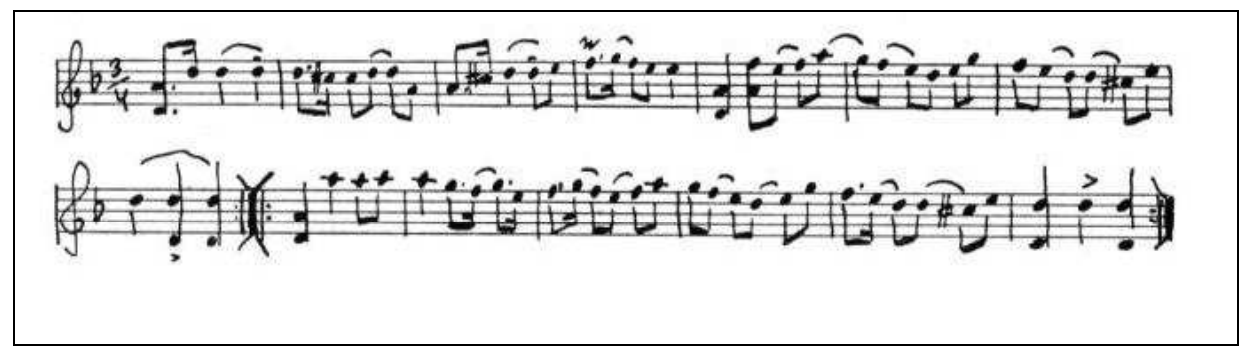

Fig.3.30: Fiol i Spann.

Outra versão sueca muito comum é a balada Sinclairsvisan, baseada num poema de 90 versos escrito por Anders Odel (1718-1773), que descreve o assassinato de um diplomata sueco a mandado do governo russo, em $1739^{72}$. Esse poema tornou-se um lugar comum independente do assunto abordado, com inúmeras variantes e canções, mas sempre com caráter político ou de protesto. O mais prestigiado poeta sueco, Carl Michael Bellman (1740-1795), também musicou a melodia da Folias de Espanha, o que reforçou ainda mais a presença dessa melodia naquele país ${ }^{73}$.

Duas famosas cantigas de ninar suecas, também utilizadas na Noruega, são variantes da já mencionada polca Fiol i Spann:

\footnotetext{
${ }^{69}$ KIRTON, Op.cit., p.4.

${ }^{70}$ Polca da ovelha.

${ }^{71}$ Violino em um balde.

${ }^{72}$ Id., ibid., p.5.

${ }^{73}$ Id., ibid., loc.cit.
} 


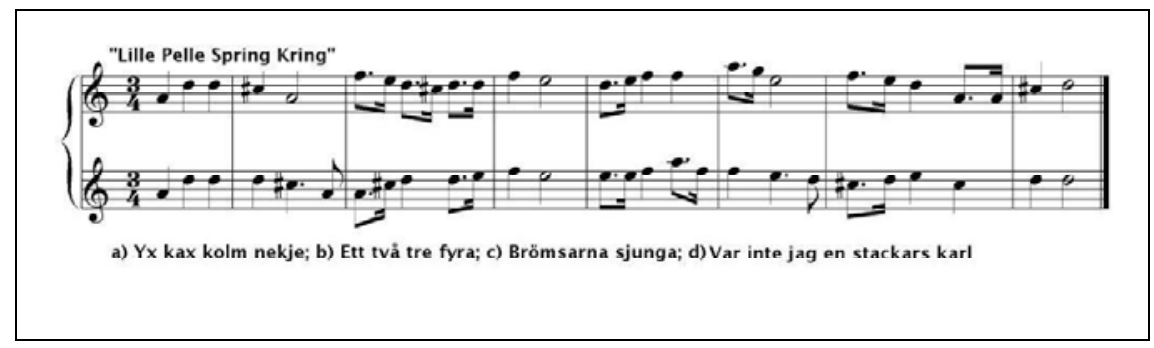

Fig.3.31: Cantigas de ninar suecas. Observe que a segunda melodia serve para quatro cantigas diferentes (a-d).

Na Noruega, a Folias de Espanha é conhecida como I Rosenlund i Sagas Hal. Esta possui, por sua vez, suas próprias variantes em danças, cantigas e baladas. A versão de Grieg foi escrita a partir da solicitação de um editor dinamarquês de que ele preparasse uma coleção de melodias folclóricas arranjadas ao piano para serem publicadas com o título genérico de Melodias Norueguesas. Devido à simplicidade de escrita dos arranjos, o compositor norueguês vendeu os direitos da coleção a Wilhelm Hanssen em 1877, embora Grieg tenha mudado sua atitude em relação às coleções de arranjos de temas folclóricos no final de sua vida ${ }^{74}$.

A antiga dança portuguesa de camponeses percorreu um longo caminho, passando por pontos altos e momentos de esquecimento, embora nunca abandonada. No final do barroco ela representou um dos mais fortes traços unificadores da música instrumental européia, uma base bem conhecida sobre a qual músicos de todas as nacionalidades poderiam improvisar sem nenhuma barreira de linguagem ou tradição musical, e uma fonte de inspiração de sucesso para qualquer compositor que ambicionasse impressionar com suas habilidades a comunidade musical européia. O Classicismo, em sua busca por estruturas evolutivas, perdeu seu interesse nas variações sobre baixos ostinatos, fazendo com que a Folias de Espanha fosse somente redescoberta pelos românticos que

\footnotetext{
${ }^{74}$ NOKLEBERG, 1995.
} 
reconheceram nela atributos para novas inspirações pessoais, unindo mestres tão díspares como Liszt e Brahms. 
CAPítulo 4:

RESSURGIMENTO NO SÉCULO XX 


\subsection{Paródia no Modernismo}

Durante a virada do século XIX para o XX, a estética musical européia passou por profundas transformações de paradigma, como reflexo de uma crise geral que se instaurou nas artes. O chamado "mal-estar" daquela época foi provocado pela incompatibilidade entre o desejo burguês de transpor as barreiras sociais e morais instauradas pela aristocracia e o sentimento de culpa por haver transposto essas convenções. Os artistas não ficaram imunes a esse paradoxo, e seu reflexo imediato está manifesto na oscilação entre as forças apolínea e dionisíaca nas artes, cuja teoria foi formulada por Friedrich Nietzsche (1844-1900): se por um lado havia o desejo de liberar os impulsos individuais, por outro existiam as convenções culturais e civilizatórias da vida em sociedade ${ }^{1}$. Carl Schorske observa que tal fenômeno contagiou todas as artes, provocando um estado de consciência cultural a-histórica:

A arquitetura moderna, a música moderna, a filosofia moderna, a ciência moderna - todas se definem não a partir do passado, e na verdade nem contra o passado, mas em independência do passado. [...]

Paradoxalmente, o esforço de lançar fora os grilhões da história acelerou os processos históricos, pois a indiferença por qualquer relação com o passado libera a imaginação, permitindo que proliferem novas formas e novas construções. (SCHORSKE, 1988, pp.13-14).

A modernidade carregou consigo a marca da tirania estética e moral. Se os patronos das artes eram obrigados a curvar-se à perfeição técnica e à genialidade pessoal dos artistas, o público também deveria elevar-se aos novos parâmetros estabelecidos - vide o caso dos prédios projetados para os trabalhadores por Walter Gropius (1883-1969) e Le Corbusier (1887-1965). Alguns modernistas, em sua atitude hermética, consideravam-se condicionadores da vida: tal posição elitista de indiferença e arrogância estava baseada na visão nietschiano-platônica de uma sociedade controlada por iluminados, cujos produtos deveriam carregar uma força impessoal, universal e trans-histórica, simbolizada pela

\footnotetext{
${ }^{1}$ SEINCMAN, 2008, p.143-146.
} 
máquina. As tradições do passado foram conscientemente descartadas em função dessa nova variedade de elitismo liberal ou de paternalismo idealista ${ }^{2}$.

Entretanto, seria simplista afirmar que esta tirania estética foi o único caminho trilhado pelo modernismo. Simultaneamente surgiram movimentos reacionários que tiveram como diretriz essencial o desejo de resgatar o equilíbrio entre a dimensão estética e social da arte enquanto comunicação e comunidade. Foi a partir desse desejo de comunicação que surgiram os movimentos neoclássicos. Instaurou-se, a partir desse novo pólo, uma cisão da arte em duas poéticas básicas: a dos formalistas e a dos conteudistas:

Os formalistas, atuando como os últimos bastiões de uma postura gestada no Romantismo, aderiram à poética da 'arte pela arte' levada às últimas consequiências, o que causaria a incompreensão e a revolta do público aliada a uma grande dose de incomunicabilidade. Mas os formalistas acreditavam que, se a arte já não se comunicava com as pessoas no presente, é porque elas ainda não estavam preparadas e o futuro iria garantir aos artistas sua verdadeira estatura de 'gênios incompreendidos'. Os conteudistas, por sua vez, ainda sob o impacto das várias revoluções do novecentos e dos movimentos socialistas e comunistas, aderiam ao anonimato da 'arte engajada' que auxiliaria a transformar as massas e a derrubar sistemas, principalmente o capitalista. Na realidade, as poéticas da 'arte engajada' ou da 'arte pela arte' possuem em comum a mesma tendência profética e visionária: desejam instaurar, desde já, um futuro melhor. Quanto à relação obra-ouvinte, enquanto a primeira busca a comunicação 'absoluta' e direta com seus ouvintes colocando a primazia no sujeito, a segunda, enfatizando o objeto, prescindirá até mesmo da comunicação em nome de um diálogo que se dará no futuro. Ambas as atitudes são compreensíveis, pois em todas as épocas há, pelo menos, duas posturas frente à realidade: a romântica e a clássica. No fundo, formalistas e conteudistas adotaram atitudes essencialmente românticas, dir-se-ia dionisíacas e extremadas: eram, em essência, idealistas. (SEINCMAN, op.cit., pp.18-19).

\footnotetext{
${ }^{2}$ JENCKS apud HUTECHEON, 1991, p.49.
} 
Não obstante, houve uma via alternativa que não buscava necessariamente o equilíbrio entre essas duas forcas, mas que utilizava os meios técnicos e expressivos tradicionais sob uma nova maneira de articulação do discurso e de organização formal. Essa poética alternativa inaugurou uma terceira via, a dos relativistas, que utilizavam o passado como matéria prima de suas composições, porém transformando seus materiais radicalmente, em cujas obras:

[...] convivem, lado a lado, o velho e o novo, o sublime e o grotesco, a seriedade e a ironia, o 'alto' e o 'baixo', o equilíbrio apolíneo e os rompantes dionisíacos, o espaço-tempo absoluto e relativo. Tais artistas, em geral, encarnam em suas próprias obras as crises materiais e existenciais da passagem do século XIX ao XX. Pode-se dizer que esta poética 'classicizante', optando pelo 'caminho do meio', foi, muitas vezes, ainda mais contundente que a dos formalistas e conteudistas, pois devido à manutenção, nessas obras, da capacidade de comunicação com o publico, este, ao mesmo tempo, em que reconhecia nelas elementos já repertoriados, era levado ao paroxismo das metamorfoses e transformações inesperadas e acachapantes que tais elementos sofriam, espelhando, com isso, as próprias convulsões dos mundos exterior e interior. (SEINCMAN, op.cit., p. 19).

A partir da exposição do quadro de referência estético do início do século XX, torna-se fácil compreender o motivo pelo qual a Folias de Espanha ficou relegada a poucas obras em estilo neoclássico (três ao todo, compostas entre 1908 e 1932) e por compositores tão díspares entre si: Miguel Llobet (1878-1938), Manuel Ponce (1882-1948) e Sergei Rachmaninoff (1873-1943). Não obstante, elas foram muito importantes para propiciar o impulso que o tema necessitava para recuperar sua evidência no século XX, afinal, se o Modernismo rejeitou o vínculo com o passado, a Pós-Modernidade o revalorizou.

O primeiro compositor a retomar o esquema tradicional das variações sobre a Folias de Espanha foi o violonista, arranjador e compositor catalão Miguel Llobet. Este foi aluno de Francisco Tárrega (1852-1909), cujas reformulações técnicas foram fundamentais para a revitalização da popularidade do violão, que estava em declínio, e da consolidação da 
técnica moderna. As obras de Llobet são descritas como nacional-românticas e possuem influência de Manuel de Falla (1876-1946), porém evidenciando os recursos violonísticos através de dedilhados cuidadosos que exploram uma ampla gama timbrística e amplas tessituras. Tais procedimentos idiomático-instrumentais o fizeram ser chamado de "violonista impressionista" e também comparado ao violoncelista Pablo Casals (1876$1973)^{3}$

Llobet publicou cerca de 100 obras, entre arranjos de melodias tradicionais e 25 composições originais. Suas obras primam por um alto grau de dificuldade técnica e interpretativa, devido à sofisticada linguagem harmônica e ao virtuosismo quase sempre presente. Sua linhagem proveniente da escola espanhola tarreguiana pode ser descrita como uma amálgama entre a concepção instrumental da escola italiana de Giuliani e a temática clássica espanhola de Sor.

O conjunto de Variaciones sobre um tema de Sor Op.15, de 1808, é uma homenagem a seu antecessor catalão. Inicia-se com uma inusual exposição literal do tema e das duas primeiras variações de Sor, adicionando mais oito novas variações intercaladas por um elegante intermezzo. Esta obra possui um perfeito equilíbrio entre inventividade e virtuosismo, pelas harmonizações que remetem aos noturnos pianísticos da segunda metade do século XIX e pelos recursos de brilhantismo exigidos ao longo da peça: passagens em ligados de mão esquerda, campanelas, harmônicos, arpejos de longa extensão, etc.:

\footnotetext{
${ }^{3}$ ANNALA \& MÄTLIK, 2008, p.97.
} 


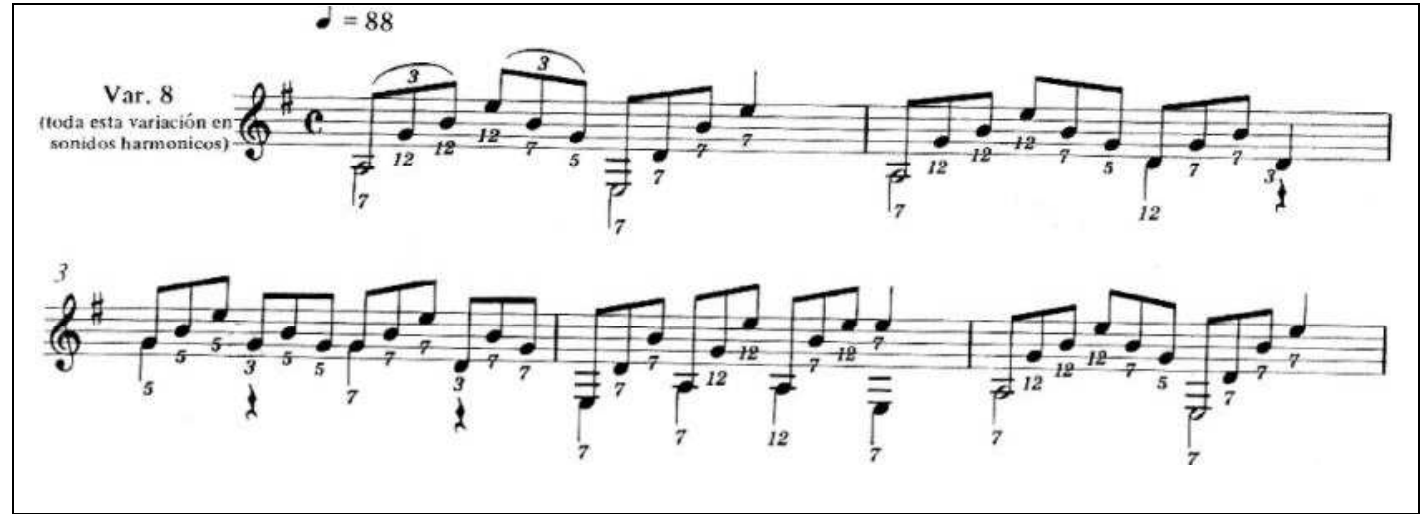

Fig.4.1: Llobet: Variaciones sobre um tema de Sor Op.15 (1808), variação VIII

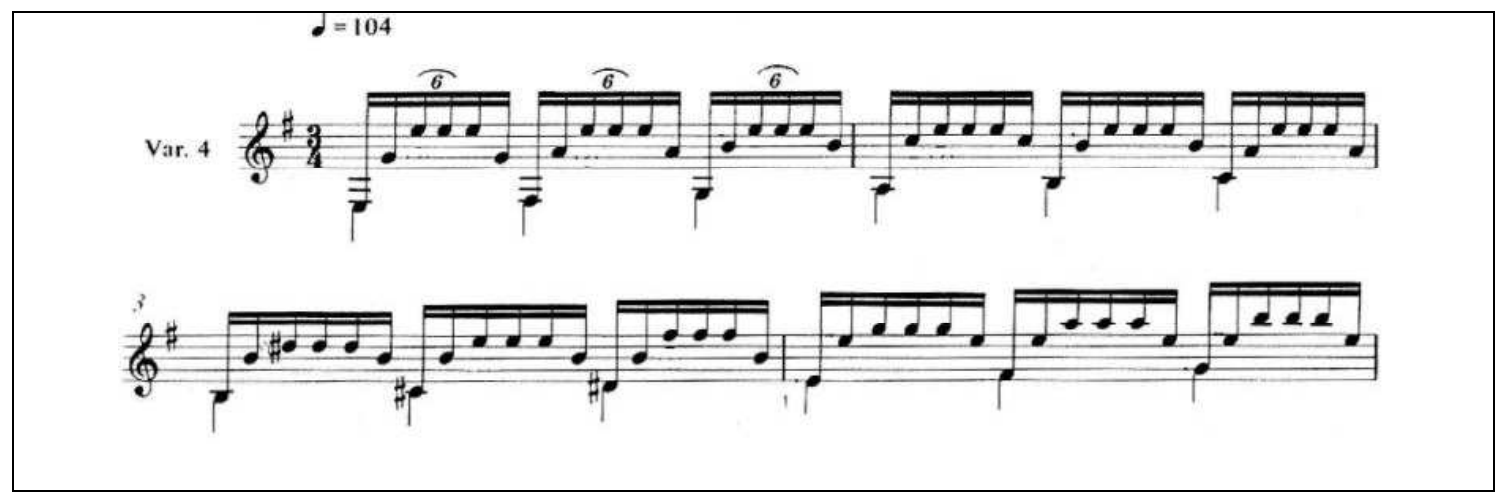

Fig.4.2: Llobet: Variaciones sobre um tema de Sor Op.15 (1808), variação IV

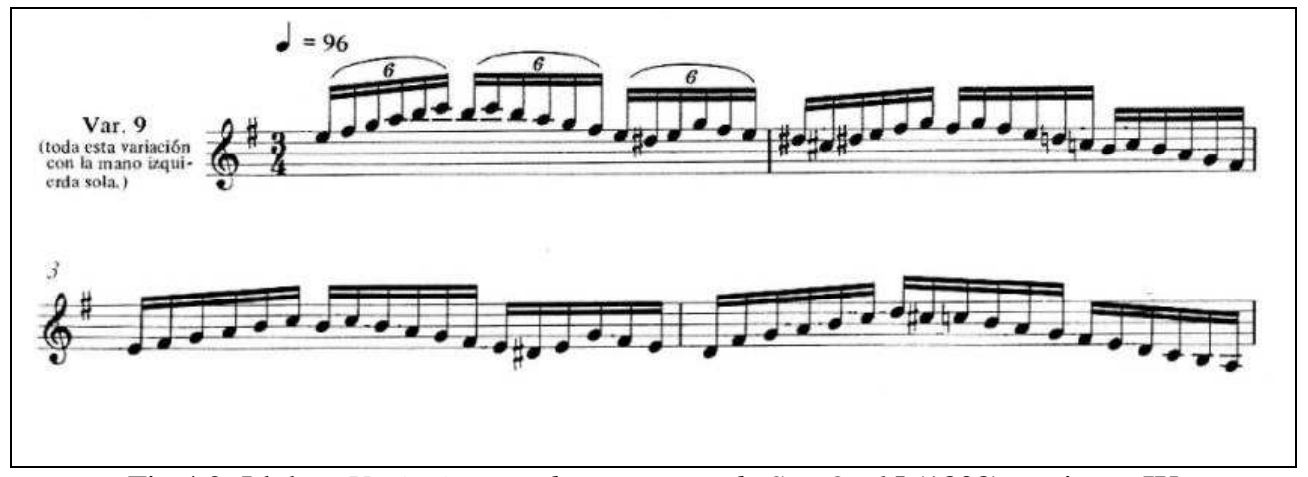

Fig.4.2: Llobet: Variaciones sobre um tema de Sor Op.15 (1808), variação IX

Todas essas características fazem com que essa obra represente um dos mais importantes momentos da criação violonística, com interessantes elementos de temporalidade, tradição e inovação. Uma comparação entre as variações de Sor e Llobet revela aspectos importantes: 


\begin{tabular}{|c|c|c|}
\hline & SOR Op.15/1 & LLOBET (1908) \\
\hline Tema & Andante (coral 3 vozes) & (idem) \\
\hline I & Marcha (terças 3 vozes) & (idem) \\
\hline II & Contraponto (terças 3 vozes) & (idem) \\
\hline III & Acordes rebatidos (terças 3 vozes) & Arpejos descendentes (tercinas, 2 vozes) \\
\hline IV & Imitação (tercinas 3 vozes) & Campanella (sextinas, 2 vozes, melodia baixo) \\
\hline $\mathrm{V}$ & --- & Harmonicos/Terças (2 vozes, melodia baixo) \\
\hline VI & --- & Arpejos ascendentes (tercinas, 2 vozes, melodia baixo) \\
\hline Interm. & --- & Intermezzo (tom maior, 3 vozes, acordes rebatidos) \\
\hline VII & --- & Ligados (3 vozes) \\
\hline VIII & --- & Harmônicos (tercinas, 3 vozes) \\
\hline IX & --- & Mão esquerda \\
\hline $\mathrm{X}$ & --- & $\begin{array}{l}\text { Finale: Acordes/Ligados/Harmônicos (4-6 vozes, tessituras G- } \\
\text { M-A) }\end{array}$ \\
\hline Coda & Minueto (tom maior: AABBA) & --- \\
\hline
\end{tabular}

Tab.4.1: análise comparativa entre as variações sobre Folias de Espanha de Sor e Llobet

A análise dos procedimentos adotados por Llobet nas Variaciones mostra que o compositor soube combinar bem o estilo de escrita coral violonística, típico de Sor, com a enunciação rápida e brilhante do estilo virtuosístico de Giuliani, realizando uma síntese perfeita entre abordagens que permaneceram historicamente separadas.

Um discípulo informal de Llobet, Andrés Segovia (1893-1987), acabou tornando-se o mais influente violonista do século XX. Nascido na Andalusia, cultivou uma carreira que 
incluiu apresentações por 78 anos consecutivos em todo o mundo, incluindo incontáveis apresentações em televisão e rádio. Sua carreira fonográfica não ficou atrás, tendo gravado praticamente todo o seu repertório de 1927 a 1977.

O comprometimento de Segovia com seu instrumento foi além de sua carreira, pois ele pretendia redefinir a imagem pública e a estatura musical do violão no século $\mathrm{XX}$ através da concretização de três objetivos:

- Divulgar um repertório clássico de alto nível ao público geral;

- Consolidar o ensino de violão em todos os conservatórios;

- Estimular publicações especializadas de violão e recrutar compositores a criarem um repertório original para o instrumento ${ }^{4}$.

Segovia inspirou vários compositores não-violonistas a escreverem obras para o instrumento. Entretanto, é preciso lembrar que o violonista espanhol era extremamente conservador em termos de repertório, e por não apreciar as inovações de linguagem que estavam em voga no século XX, desperdiçou a oportunidade de encomendar obras a compositores de prestígio como Bartók ou Stravinsky. Não obstante, graças à sua influência, o repertório do violão conta hoje com obras originalmente escritas por Heitor Villa-Lobos, Federico Mompou, Joaquín Rodrigo, dentre outros.

Um desses compositores foi Manuel Ponce (1882-1948), que nasceu no México e iniciou seus estudos musicais em seu país, continuando-os em Bolonha e Berlim, de 1904 a 1908. Residiu posteriormente em Paris entre 1925 e 1933, e deixou grande quantidade de obras para orquestra, concertos e música de câmara ${ }^{5}$. Segovia tinha especial predileção

\footnotetext{
${ }^{4}$ ZANON, 2009.

${ }^{5}$ OTERI, 2009.
} 
pelas obras de Ponce em relação aos demais compositores recrutados por ele a escrever para o violão, devido às afinidades estéticas e intelectuais entre ambos.

A obra Variations sur "Folia de España” y Fuga foi uma das várias encomendas de

Segovia a este compositor: composta entre dezembro de 1929 e maio de 1931 em Paris, estreada em fevereiro de 1930 em Nova Iorque e publicada em 1932 pela editora B. Schott's Söhne, em Mainz ${ }^{6}$.

De acordo com a intensa correspondência entre ambos no mês de dezembro de 1929

(seis cartas ao todo), o violonista já estabeleceu de antemão a configuração geral que a futura obra deveria apresentar:

Quero que me faças algumas variações brilhantes sobre o tema Folias de España, em Ré menor, da qual te envio uma cópia do manuscrito de Berlim. Num estilo situado entre o classicismo italiano do XVIII e o início do romantismo alemão. Isso eu te peço de joelhos... Se você não quiser assiná-las atribuiremos a Giuliani, de quem há muitas coisas ainda por serem descobertas, e de quem acabam de me dar um manuscrito de Moscou. Quero que esta obra seja a melhor peça dessa época, o pendant das [variações] de Corelli para violino sobre o mesmo tema. Comece a fazer variações e as me envie, e procure incluir todos os recursos técnicos do violão, por exemplo, variações em acordes simultâneos de três notas, em oitavas, em arpejos, sucessões rápidas que ascendam até o $\mathrm{Si}$ bemól mais agudo e que terminem no Ré grave, encadeamentos de vozes em movimentos polifônicos nobres, notas repetidas, um cantabile maior que relace a beleza do tema, entrevisto através do enredo engenhoso da variação, e retornar a ele, para concluir com acordes amplos, depois de exibir toda a nobre astúcia musical de que você é capaz de demonstrar, para distrair o ouvinte da proximidade definitiva do tema...! Doze ou catorze variações ao todo, obra de meio programa que não pareça longa pelos contrastes de cada variação com a que a precede e a segue. O tema é adorável. Faça com que toquem as [variações] de Corelli no gramofone se não se lembra delas, e verá como é um grande pecado que esse tema, cuja versão mais antiga é o manuscrito de Berlim, para alaúde, espanhol, está exilado do violão, ou tratado raquiticamente por Sor, o que é pior. (SEGOVIA apud ALCÁZAR, 1989, pp.4748 , tradução nossa). ${ }^{7}$

\footnotetext{
${ }^{6}$ Mogúncia, distrito urbano da Alemanha.

${ }^{7}$ No original: "Quiero, que me hagas unas variaciones brillantes sobre el tema de las Folias de España, en Re menor, y cuya copia del manuscrito de Berlín te envío. En un estilo que linde entre el clasicismo italiano del XVIII y los albores del romanticismo alemán. Esto te lo pido de rodillas... Si tú no las quieres firmar se las adjudicaremos a Giuliani, de quien hay muchas cosas por descubrir, y de quien acaban de darme un manuscrito en Moscou. Quiero que esta obra sea la mejor pieza de esa época, el pendant de las de Corelli para violín sobre el mismo tema. Ve haciendo variaciones y mándame-las, y procura que contengan todos los recursos técnicos de la guitarra, por ejemplo variaciones en acordes simultáneos de tres notas, en octavas, en arpegios, sucesiones rápidas que asciendan hasta el Si b sobreagudo y que expiren en el Re grave, enlace de voces en nobles movimientos polifónicos, notas repetidas, un mayor cantabile que realce la belleza del tema,
} 
A descrição inicial de Segovia revela um conhecimento satisfatório sobre o tema se considerarmos a falta de informações musicológicas sobre a Folias de Espanha na década de 1920 - embora limitado ao "manuscrito de Berlim", Corelli e Giuliani. O perfil estético solicitado por Segovia, entre o classicismo italiano oitocentista e o início do romantismo, coincide com auge da popularidade do tema, conforme vimos em capítulos anteriores $^{9}$, o que reflete uma interessate intuição por parte do músico espanhol.

Segovia chegou a sugerir que Ponce utilizasse o pseudônimo de Giuliani, recurso utilizado por diversos compositores - como o conhecido caso de Kreisler ${ }^{10}$ - e pelo próprio compositor mexicano em outros trabalhos, que visava dois objetivos: preservar a reputação de compositores que não estivessem alinhados com a estética modernista da primeira metade do século XX e iludir a crítica musical da época, que não dispunha das mesmas ferramentas de pesquisa dos musicológicos e conseqüentemente não conseguia distinguir estilisticamente as obras redescobertas daquelas escritas por compositores desconhecidos que precisavam adquirir alguma reputação. Ponce era essencialmente um compositor neoclássico, que dominava bem as linguagens dos estilos barroco, clássico e romântico e assinou diversas obras sob diferentes pseudônimos, como, por exemplo, a Suite Antigua (1931), atribuída ao alaudista do barroco alemão Sylvius Leopold Weiss (1687-1750) ${ }^{11}$ e praticamente escrita na mesma época das Variações sobre Folias de Espanha. Ponce não

entrevisto a través del enredo ingenioso de la variación, y volver a él, para concluir con grandes acordes, después de derrochar toda la nobre astucia musical de que tú eres capaz, para distrair al que oye, ¡de la proximidad del tema...! En todo doce o catorce variaciones, obra de toda una parte del programa, que no se hará larga, por el contraste de cada variación con la que la precede y la sigue. El tema es adorable. Haz que te toquen en el gramofono las de Corelli, si no las recuerdas, y veras como es un gran pecado que ese tema, cuya version mas antigua es el manuscrito de Berlin, para luth, español, ademas, hasta la medula, esté destarrado de la guitarra, o tratado por Sor, raquiticamente, lo que es peor."

${ }^{8}$ Supostamente a própria Sonata Op.5/12 de Corelli.

${ }^{9}$ Cf. capítulos 2.4 e 2.8 desta tese.

${ }^{10}$ Fritz Kreisler (1875-1962) foi um renomado violinista austríaco que compôs, no início do século XX, várias obras ao estilo de Vivaldi e Corelli, atribuindo-lhes suas autorias. Em 1935 ele desfez o mito assumindo a autoria das obras, e a controvérsia gerada por esse episódio rendeu-lhe a atenção dos críticos.

${ }^{11}$ Ironicamente, a obra para alaúde de Weiss popularizou-se após os epígonos de Ponce. 
julgou necessário valer-se de tal recurso desta vez, pois viu na encomenda uma excelente oportunidade para concretizar um projeto ambicioso pessoal, como veremos em seguida.

$\mathrm{Na}$ correspondência de Segovia a Ponce que se seguiu à encomenda da obra, o violonista elogia um grupo de três variações iniciais enviadas inicialmente, mas destaca que as três seguintes ${ }^{12}$, recém chegadas, são melhores: “As três variações que acabam de chegar são admiráveis [...] As três primeiras estão muito boas, sobretudo a segunda, de que gosto muito. Mas estas três últimas são muito superiores à suas companheiras.",13.

Em seguida, na mesma missiva, pergunta se ele não gostaria de chamar Diferencias, como na tradição da música espanhola antiga, e sugere um final que não seja uma fuga para não "esfriar" o público. Como as réplicas de Ponce não foram publicadas, supomos pelas entrelinhas das próprias cartas de Segovia que o compositor havia sugerido uma fuga ao invés de um gran finale, como o violonista havia solicitado de início.

Na correspondência que se seguiu, Segovia finalmente acedeu ao formato sugerido por Ponce, que consistia em um prelúdio, variações e fuga sobre a Folias de Espanha. Aparentemente, Ponce deve ter se posicionado contra o uso do tema barroco enviado por Segovia (possivelmente por já ter em mente o uso de uma linguagem harmônica mais sofisticada para iniciar a obra), ao que o músico espanhol respondeu afirmando que "se o tema não te agrada, transforme-o ao seu gosto, sempre o fará melhor"14.

Na carta seguinte, o violonista acusa a chegada de mais quatro variações e adverte o compositor sobre uma delas, qualificando-a como portadora de uma "dificuldade

\footnotetext{
${ }^{12}$ Possivelmente as variações VIII, IX e X.

${ }^{13}$ SEGOVIA apud ALCÁZAR, op.cit., p.51. No original: "Las tres variaciones que acaban de llegar son admirables [...] Las tres primeras estan muy bien y sobretodo la segunda de ese grupo, me gusta mucho. Pero estas tres ultimas, son muy superiores a sus compañeras."

${ }^{14}$ Id., ibid., p.51.
} 
insuperável” ${ }^{\prime 15}$. Segovia solicitou a Ponce - que havia prometido o envio de mais cinco variações - que as fizesse com recursos instrumentais, com o uso de harmônicos, por exemplo.

O violonista voltou a posicionar-se contra a presença de uma fuga, argumentando que esta seria adequada para platéias cultas de grandes centros como Berlim, Londres e Paris, mas que para um público "menos elevado" seria mais oportuno ter, como reserva, um final curto e brilhante ${ }^{16}$. Segovia reforça o pedido de envio do prelúdio e da fuga. Ainda em finais do ano de 1929, acusa o recebimento da fuga e elogia enfaticamente seu conteúdo musical, prevendo que a obra em gestação "é o melhor que o violão possui, a grande distância de outras coisas, e depois desta obra a mais valiosa é tua Sonata a Schubert ${ }^{17}$. É impossível dizer-lhe por escrito o quanto estou entusiasmado" $" 18$.

Em janeiro de 1930, Segovia escreve de Bremen dizendo que perdeu duas páginas da primeira versão do prelúdio, e pede para Ponce reescrevê-lo. Na verdade, ele solicita uma nova elaboração em vista da dificuldade que a peça apresentava, muito mais complexa que a fuga e as dez variações já compostas até aquele momento ${ }^{19}$.

Em uma longa carta escrita em Palm Beach e datada de 26 de fevereiro de 1930, Segovia informa Ponce que a nova versão do prelúdio está satisfatória, e que as dificuldades de mãos esquerda desepareceram. Seu entusiasmo é marcante, e ele chega a afirmar que esta é uma das maiores obras do repertório violonístico. Das variações recémchegadas, elogia a primeira e critica as restantes como inferiores em relação ao que o

\footnotetext{
${ }^{15}$ ALCÁZAR, 2000, p.55. Provavelmente a variação XIV.

${ }^{16}$ Id., ibid., p.56.

${ }^{17}$ Sonata Romántica: Hommage a Fr. Schubert qui aimait la guitare (1928).

${ }^{18}$ Id., ibid., p.58

${ }^{19}$ Id., ibid., p.59
} 
compositor já havia escrito até então ${ }^{20}$. Segovia lança, então, uma nova proposta: usar o prelúdio para ser tocado com a fuga, em separado do ciclo de variações, e utilizar o um dos prelúdios (o de N.6 na edição Schott de 1930) como introdução às variações. Como não há mais referências a essa proposição de Segovia, pressupomos que Ponce a rejeitou.

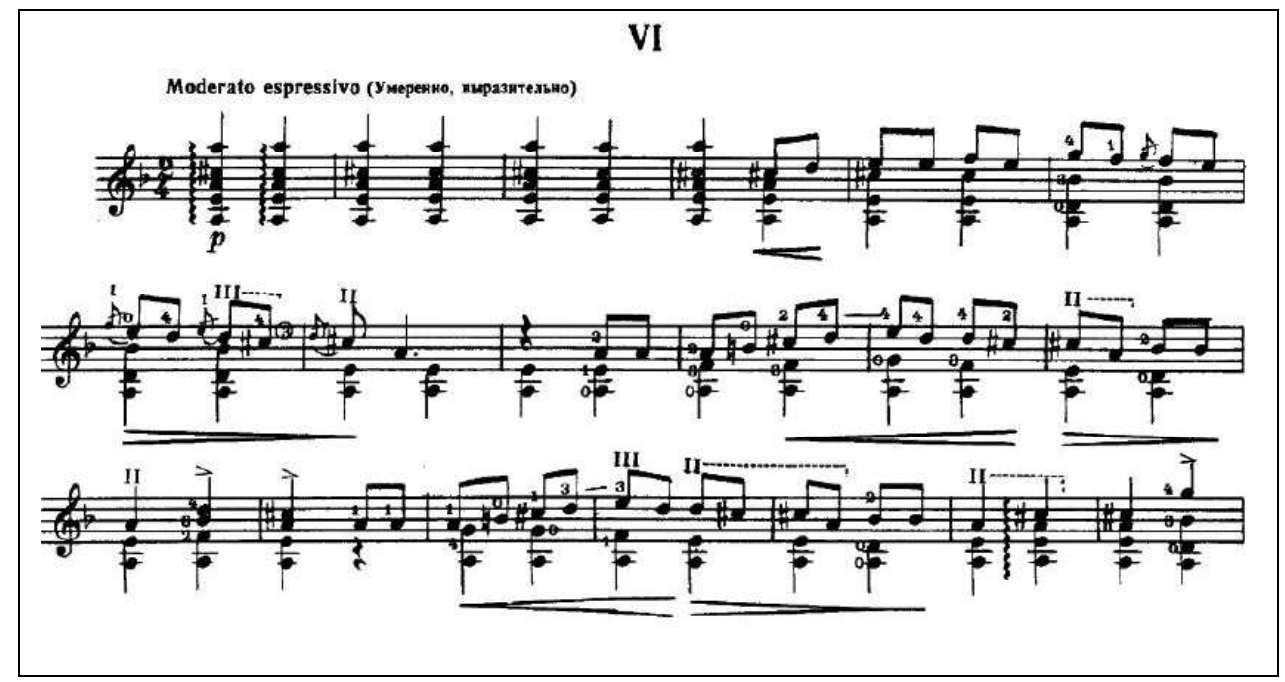

Fig.4.4: Ponce: Preludio N.6

De acordo com as réplicas e argumentações de Segovia, é possível supor que ele e Ponce estivessem negociando o formato final da obra, que provavelmente deveria estar nas seguintes configurações:

- para Segovia: Prelúdio 6 - tema (“manuscrito de Berlim”) - 12 a 14 variações - gran finale; Prelúdio (Postlude) e Fuga (em separado do ciclo);

- para Ponce: Prelúdio - tema (reelaborado) - 20 variações - fuga.

Segovia afirmava que a fuga prolongaria demasiadamante a obra em concertos, e que seria obrigado a sacrificar algumas variações. Em uma carta posterior, de 29 de novembro de 1932, ele solicitou mais uma vez um novo finale, mais curto, argumentando que a fuga sozinha é auto-suficiente ${ }^{21}$. De certa forma, Ponce não deixou de atender

\footnotetext{
${ }^{20}$ Possivelmente as variações XIII, XIV, XV e XX.

${ }^{21}$ ALCÁZAR, 2000, p.134
} 
Segovia neste aspecto, pois os compassos finais da fuga estão escritos com amplos acordes, exatamente como o violonista solicitou em sua primeira carta:

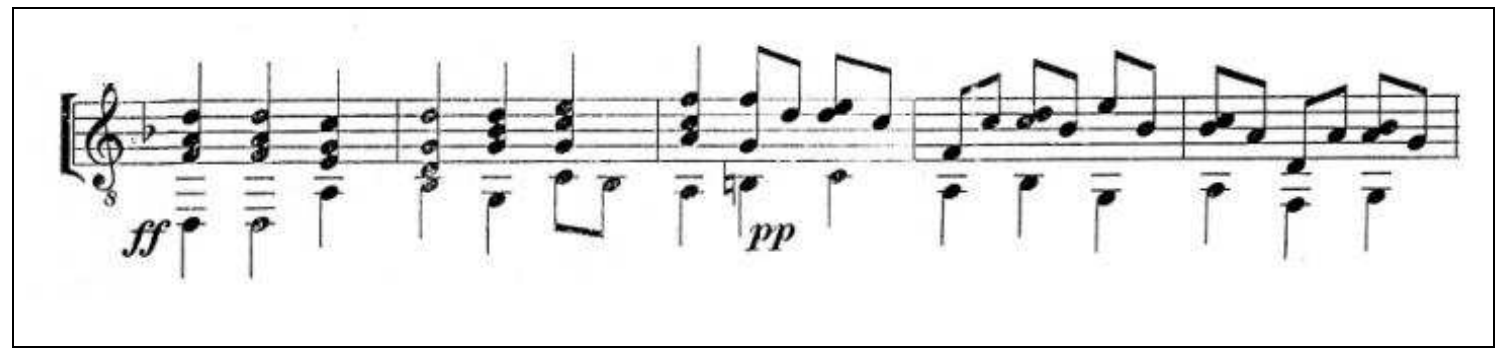

Fig.4.5: Ponce: Variations sur “Folia de España” y Fuga, Fuga, c.93-97

É interessante observar que todo o processo se transformou em uma longa negociação entre os projetos e as ambições individuais entre o compositor (que planejava uma obra de proporções beethovenianas) e o violonista (desejoso de ter em seu repertório uma obra tão brilhante quanto as variações de Corelli), e que está evidenciada na gravação realizada pelo próprio Segovia em outubro de 1930 em Londres, que escolheu a seguinte seqüência:

- Tema (“manuscrito de Berlim”) - variações II, III, VIII, IV, V, IX, X, VII, XII, XX fuga. ${ }^{22}$

- Prelúdio, em separado, intitulado como Postlude.

Podemos auferir que o título Postlude pode ter sido uma maneira sutil que Segovia encontrou para evidenciar o seu desejo de desmembramento da peça do conjunto de variações, como algo excedente, o que reforça a nossa suspeita de que havia uma diferença entre o desejo de Segovia por uma obra virtuosística de caráter neobarroco italiano evidenciado pela carta de encomenda da obra - e o de Ponce, que talvez ambicionasse uma

\footnotetext{
${ }^{22}$ Outros intérpretes efetuaram semelhantes modificações ou redução do material para gravações e performances. O violonista alemão Tilman Hoppstock, por exemplo, realizou uma gravação que buscou uma coerência interna entre as variações agrupando-as em pequenos blocos na seguinte seqüência: I, II, IV, X, IX, XIV, XV, XVI, VI, XII, XVIII, XVII, XIX, Fuga. Cf. HOPPSTOCK, 2000.
} 
obra de proporções beethovenianas. Este último incorporou ao ciclo pelo menos três procedimentos das Variações Diabelli:

a) "Negação do tema" na primeira variação, com evidente contraste entre as métricas (3/4 e 4/8);

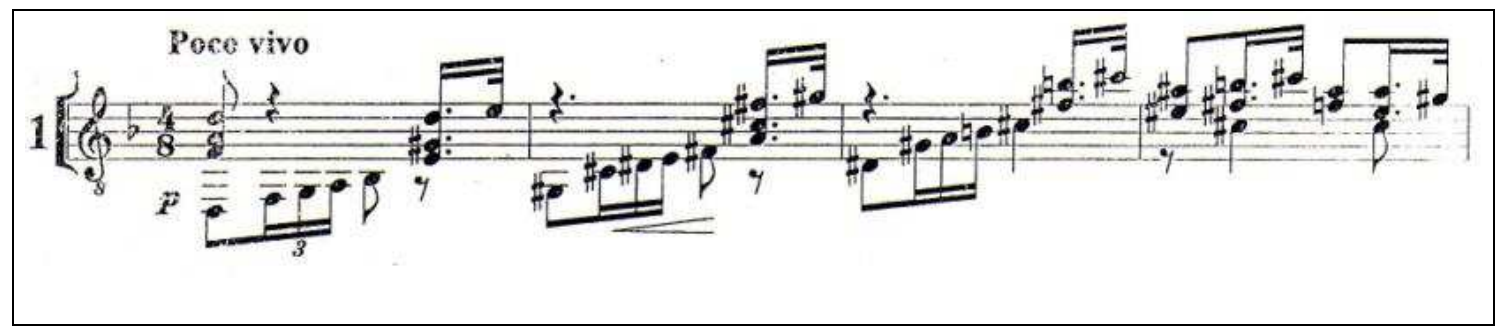

Fig.4.6: Ponce: Variations sur "Folia de España” y Fuga, Variação I

b) Inclusão de uma fuga concluindo um longo ciclo de variações;

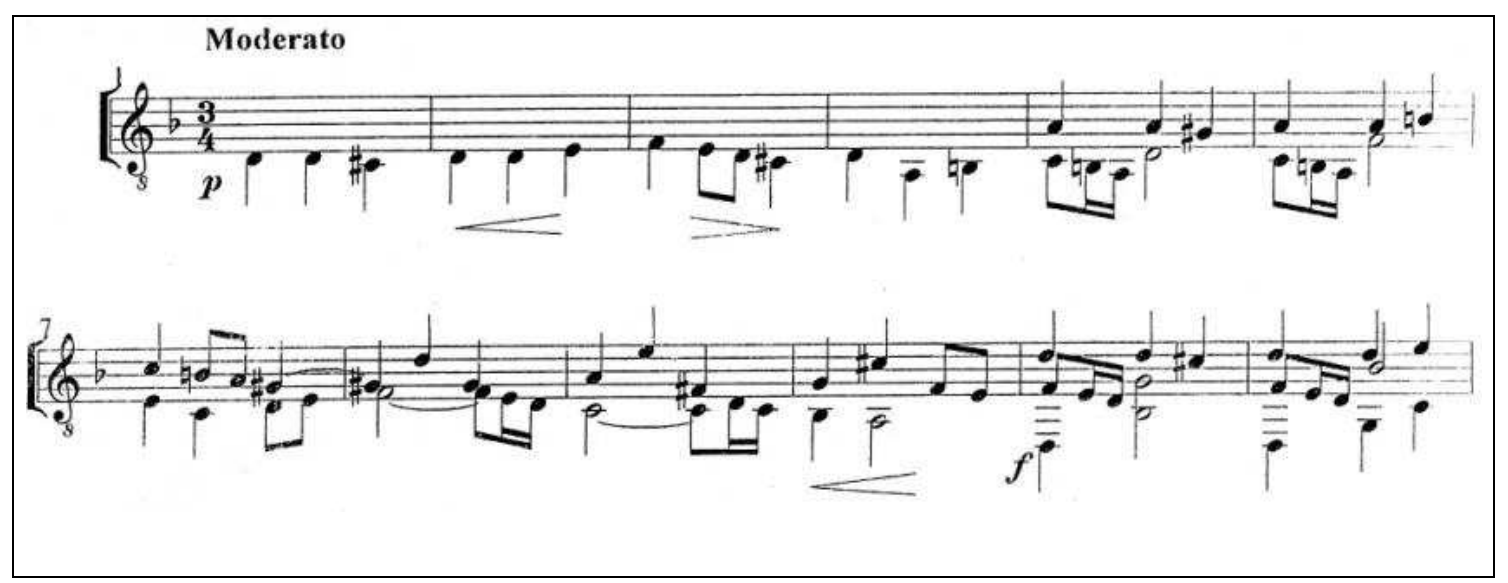

Fig.4.7: Ponce: Variations sur "Folia de España" y Fuga, Fuga

c) Individualização de cada variação com conexões das variações entre si durante a sequiência, ao invés de sempre relacionadas ao tema principal. Uma audição do ciclo completo evidencia que apenas as variações de I a IV são reconhecíveis como derivadas diretamente do tema, e que essa aproximação temática só é retomada nas variações finais (XV-XVI e XIX-XX) e na fuga. 
As correspondências seguintes entre os músicos não mencionam mais sobre o processo de elaboração e revisão da obra, centrando-se em detalhes comerciais de publicação e edição da partitura. Porém, em 31 de maio de 1931, Segovia solicita mais uma variação a ser incluída no set, mais longa e em trêmolo ${ }^{23}$.

Segovia sempre interveio no trabalho dos compositores a quem encomendava obras. A influência do violonista é patente no repertório escrito para ele: predominância de peças fortemente idiomáticas e de fácil aceitação pública, esteticamente conservadoras e que não se alinhavam à vanguarda musical da época. Segovia também sugeria modificações de trechos inteiros sob o argumento de que tais alterações tornariam essas peças mais idiomáticas, o que na verdade tornava essas peças mais próximas de seu gosto musical particular. Praticamente toda peça que Segovia gravava, editava e tocava era sempre uma versão muito distante do manuscrito original. Nem sempre essas divergências eram estruturalmente relevantes, mas alteravam significativamente o resultado sonoro final da obra. Em Ponce essa interferência era maior, e nas variações sobre Folias de Espanha tratase praticamente de um trabalho de co-autoria.

É importante destacar que, de todas as variações de Ponce, existem dois perfis contrastantes: um de natureza técnica-instrumental, visando atender à expectativa e encomenda de Segovia, e outro estrutural-característico, revelando a seriedade estética de Ponce:

\footnotetext{
${ }^{23}$ Variação XVI.
} 


\begin{tabular}{|l|l|}
\multicolumn{1}{|c|}{ Variações Técnicas (Segovia) } & \multicolumn{1}{c|}{ Variações Características (Ponce) } \\
\hline Acordes (IV, XIV) & Prelúdio \\
\hline Oitavas (XV) & Tema \\
\hline Arpejos (VI, X) & I (alusão rítmica ao jazz) \\
\hline Virtuosísticas (II, VIII, XVII) & XI (alusão rítmica ao gênero pastoral) \\
\hline Polifônicas (III, V, VII, XIII) & XIX (alusão rítmica a um foxtrot) \\
\hline Notas repetidas (XVIII) & Fuga \\
\hline Cantabile (IX) & \\
\hline Harmônicos (XX) & \\
\hline Trêmolo (XVI) & \\
\hline
\end{tabular}

Tab.4.2: comparação entre as variações técnicas e características

A escolha de Ponce para a ordem das variações prevaleceu para a publicação pela Schott, em 1932. A demora na publicação, de acordo com Segovia, se deveu ao fato de que o editor pediu-lhe que enviasse obras mais complexas em intervalos de tempo mais prolongados. Observamos um cuidado minucioso na escolha da ordem das variações, pensada de maneira meticulosamente estrutural: as variações características servem como balizas das preponderantemente técnicas, situadas nas pontas (I e XIX) e no centro (XI). Esta última, "pastoral", é a única na tonalidade de Dó maior, em andamento médio (andantino), funcionando como um eixo de contraste tonal no mapeamento geral da obra. 


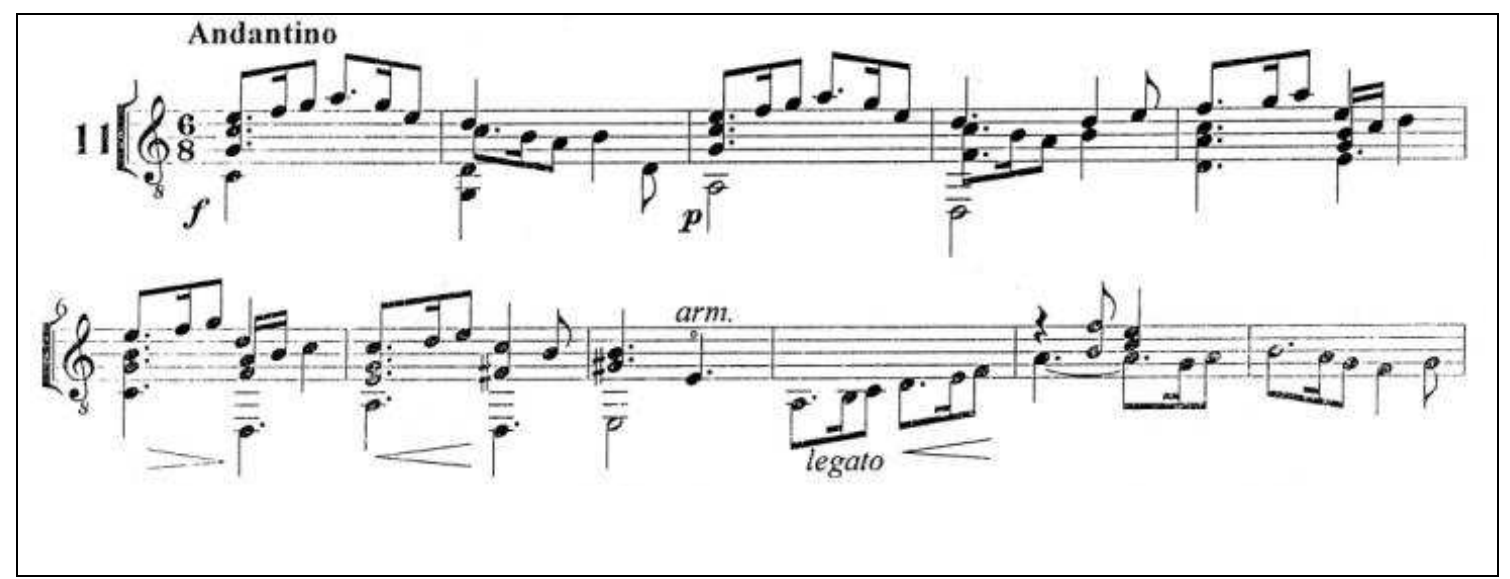

Fig.4.8: Ponce: Variations sur "Folia de España” y Fuga, variação XI

As variações buscam, de modo geral, contrastes entre cores e expressões, porém uma leitura hermenêutica de algumas das variações revela detalhes interessantes, tomando exclusivamente como referência o próprio sentido implícito em cada uma das variações:

- Prelúdio: Postlude: trata-se claramente de uma homenagem à música árabe; talvez Ponce estivesse pretendendo resgatar uma possível conexão com a própria música espanhola.

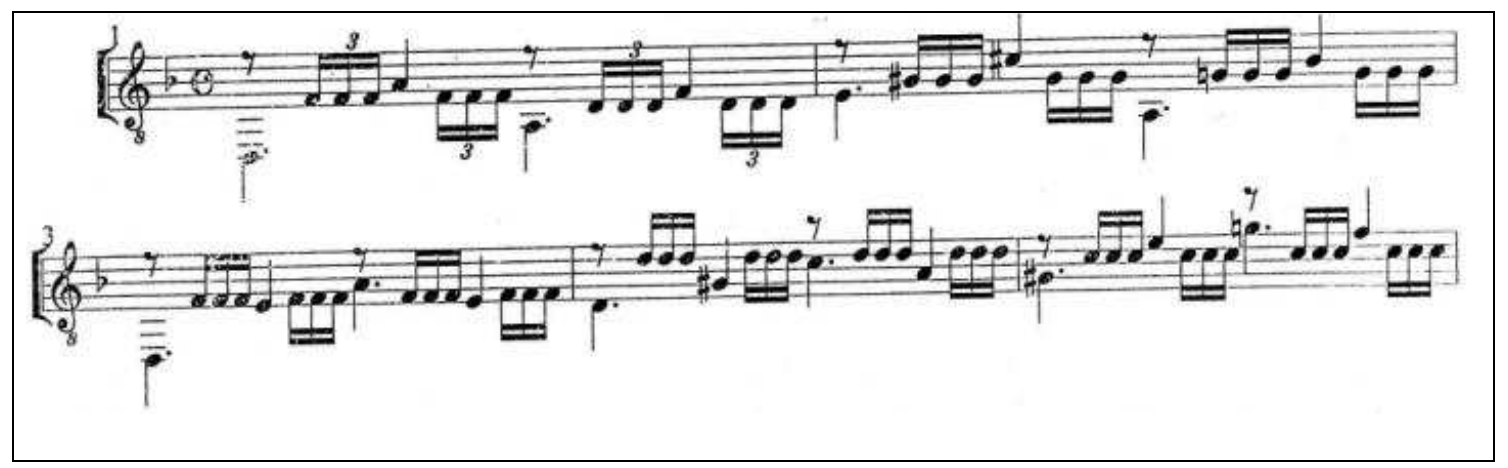

Fig.4.9: Ponce: Postlude

- Thème - Lento: o tratamento do tema enfatiza a sarabanda, como se fosse uma alvorada do universo barroco, porém com uma harmonia enriquecida. Essa mistura traz uma idéia de simultaneidade temporal - é barroca e moderna ao mesmo tempo. 


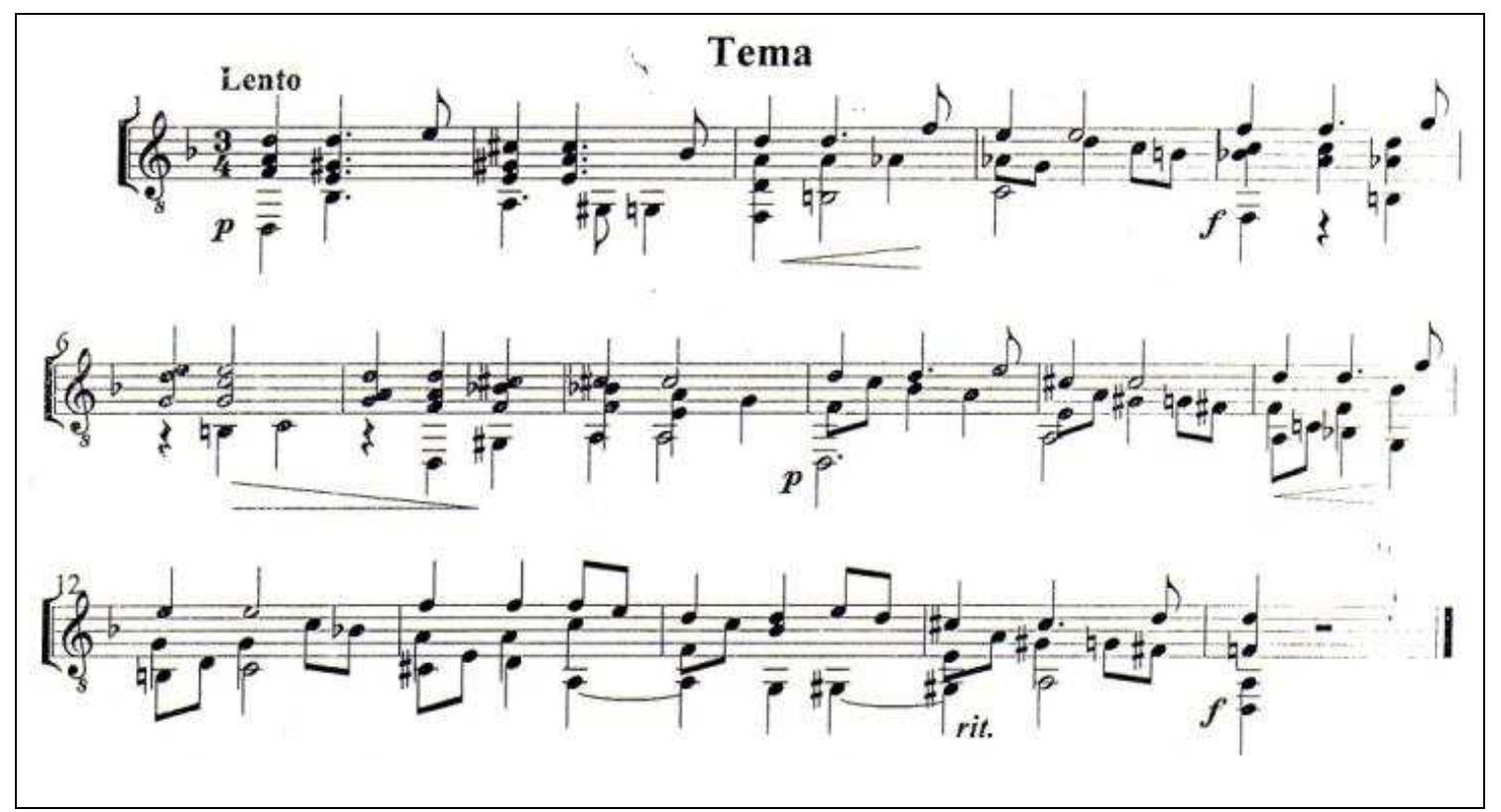

Fig.4.10: Ponce: Variations sur "Folia de España” y Fuga, Tema

- Variação I - Poco vivo: o ritmo empregado remete ao ambiente da música popular, quase jazzística. Este procedimento, como já vimos, é o mesmo que Beethoven utilizou nas Variações Diabelli, com o contraste entre o tema (valsa) e a primeira variação (marcha). O contraste entre danças pode ser lido dentro de um contexto social, em que as tradições da elite e do povo se chocam pela proximidade e pelo contraste gerado pelo tempo ternário e binário.

- Variação XI - Andantino: alusão à estética do Classicismo, com uma escrita em estilo pastoral.

- Variação XVIII - Allegro scherzando: homenagem a Fernando Sor, com empréstimo temático direto. 


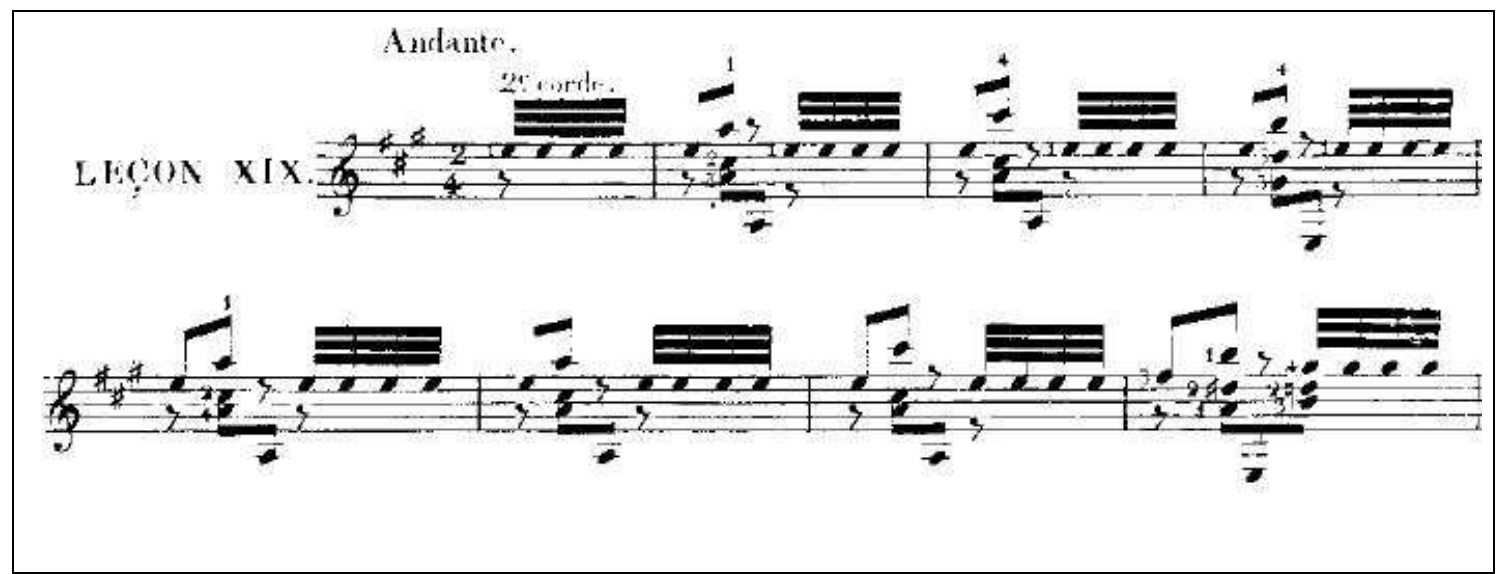

Fig.4.11: Sor: Estudo Op.35 N.19

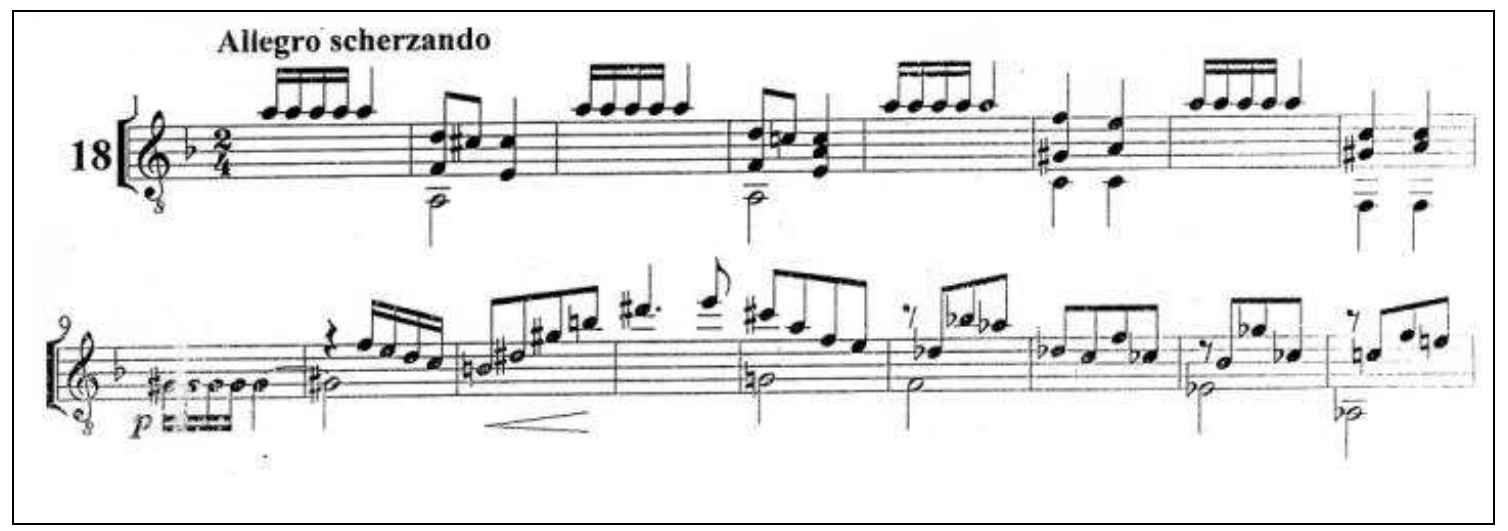

Fig.4.12: Ponce: Variations sur “Folia de España” y Fuga, variação XVIII

- Variação XIX - Vivo e marcato: retornamos ao ambiente da música popular com a inserção do ritmo foxtrot.

- Fugue - Moderato: conclui a obra reafirmando o barroco ao utilizar o velho procedimento de concluir uma obra grande com a fuga, que sintetiza o ápice da elaboração contrapontística e harmônica.

As Variações de Ponce tornaram-se rapidamente uma das peças mais importantes do repertório violonístico, sendo hoje a mais gravada (por mais de 30 intérpretes) dentre todas as composições para violão que se baseiam na Folias de Espanha. 
Já no repertório pianístico, uma das versões mais gravadas do tema Folias de Espanha (cerca de 50) são as Variações sobre um Tema de Corelli Op.42 de Rachmaninoff. A obra resultou da calorosa amizade entre o pianista russo e o violinista Fritz Kreisler, que não resultou em uma composição para violino, como era de se esperar, mas num conjunto de variações para piano solo dedicadas ao violinista. Kreisler lhe apresentou a melodia "La Folia" como sendo de autoria de Corelli, o que justifica o título. O uso que Rachmaninoff faz do tema barroco inclui algumas notas complementares cromáticas. Além disso, ele modificou o andamento Adágio, contido na Sonata de Corelli, para Andante ${ }^{24}$. É também possível que Rachmaninoff também tivesse o Sexteto Op.18 de Brahms - na versão para piano publicada em 1930 - como uma fonte adicional de inspiração composicional.

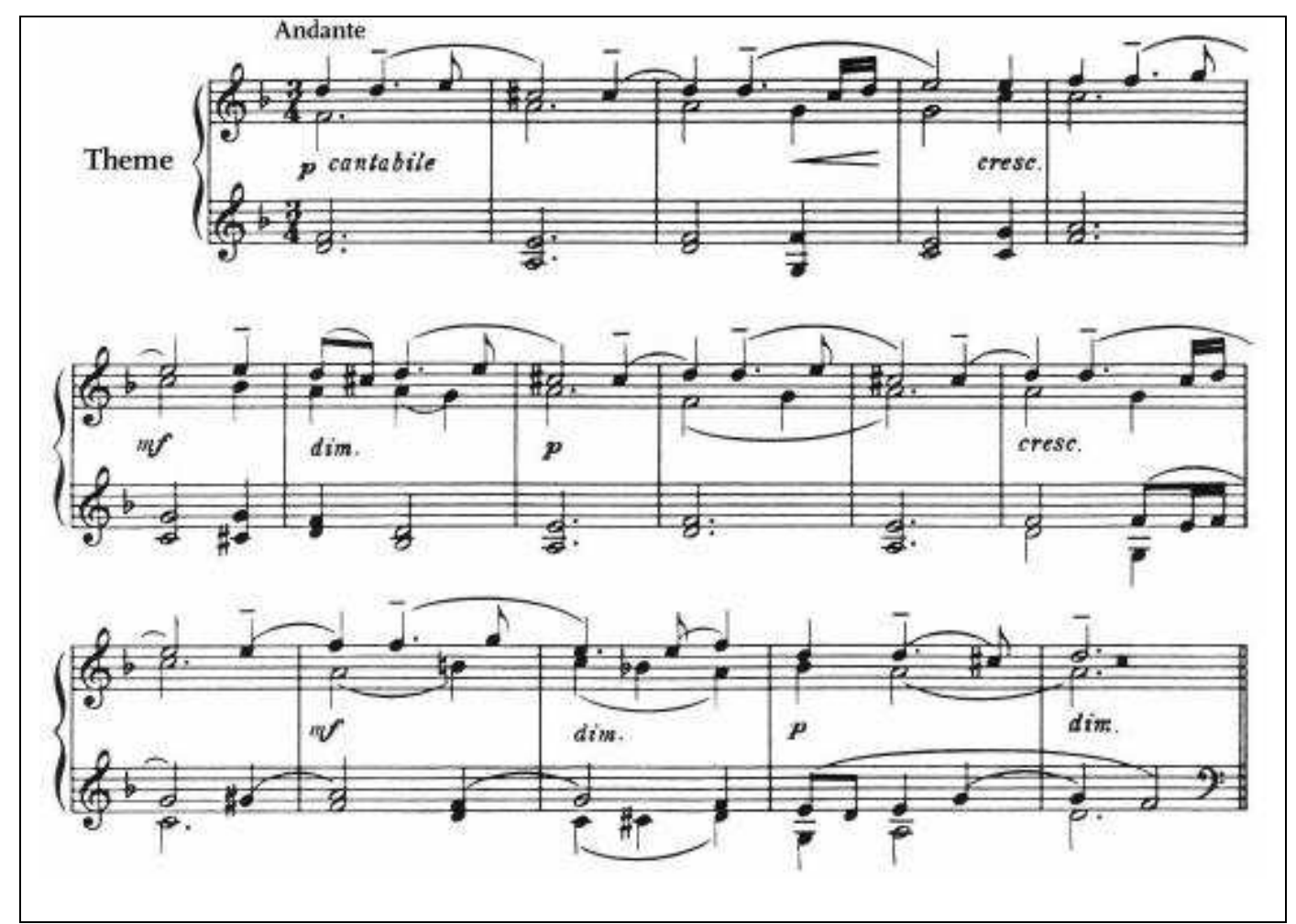

Fig.4.13: Rachmaninoff: Variações sobre um Tema de Corelli Op.42, Tema

\footnotetext{
${ }^{24}$ GLOVER, 2003, p.70.
} 
A obra foi composta durante o verão de 1931 num momento de certa frustração para o compositor, pois em janeiro daquele mesmo ano, seu nome apareceu como um dos signatários de uma carta criticando o governo na Rússia no The New York Times. Dois meses depois, em uma crítica de Moscou sobre a execução de sua composição The Bells, ele foi descrito como inimigo da União Soviética, o que deu início a um boicote ao estudo e às execuções de sua música na Rússia. Embora Rachmaninoff afirmasse estar orgulhoso de ser o objeto de tal ira, isso o feriu profundamente. Apesar disso, ele começou a compor as Variações Corelli no final de maio, em Clairefontaine, França. Embora ele se queixasse de que não tinha tempo para compor e que escrever música naquela idade era mais difícil do que quando mais jovem, ele terminou rapidamente a composição da obra, em 19 de junho de 1931.

Este não é apenas seu último trabalho para piano solo, mas de fato a única obra para piano composta durante seus vinte e seis anos de exílio nos Estados Unidos. Rachmaninoff a tocou pela primeira vez em Montreal, em outubro de 1931. Estas variações marcaram um retorno ao entusiasmo pela composição desde a fria recepção do Concerto para piano No.4 Op.40 (1926), mas apesar de toda a clareza de sua textura, elas foram novamente mal recebidas pelo público. $\mathrm{O}$ excesso de autocrítica que atormentava Rachmaninoff o levou a indicar na partitura que as variações XI, XII e XIX poderiam ser omitidas, caso o intérprete desejasse. Ele escreveu ao seu compatriota, o compositor Nicholas Medtner (1880-1951), a respeito desse trabalho em 1931:

Estou lhe enviando minhas novas variações. Eu as toquei aqui aproximadamente quinze vezes, mas destas quinze apresentações, apenas uma foi boa. As outras foram desleixadas. Eu não consigo tocar minhas próprias composições! E isso é muito chato! Nem uma vez que eu toquei todas elas em seqüência. Eu fiquei guiado pela tosse da platéia. Sempre que a tosse aumentava, eu pulava para a variação seguinte. Sempre que não havia tosse eu tocava na ordem correta. Em um concerto, não me lembro onde - alguma cidade pequena, a tosse foi tão violenta que eu só toquei dez variações (das vinte). Minha melhor marca foi em 
Nova York, onde toquei dezoito variações. (RACHMANINOFF apud HINSON, 1982). ${ }^{25}$

As Variações Corelli representam a segunda vez que o compositor abordou essa forma: a primeira foi com as Variações sobre um Tema de Chopin Op. 22, compostas entre 1902 e 1903; ele ainda retomaria a forma na famosa Rapsódia para Piano e Orquestra Sobre um tema de Paganini Op. 43, para piano e orquestra, de 1934. As Variações Corelli podem ser consideradas como uma espécie de estudo preparatório para a Rapsódia. As variações IV e VIII parecem antecipar certas passagens que são encontradas na obra posterior.

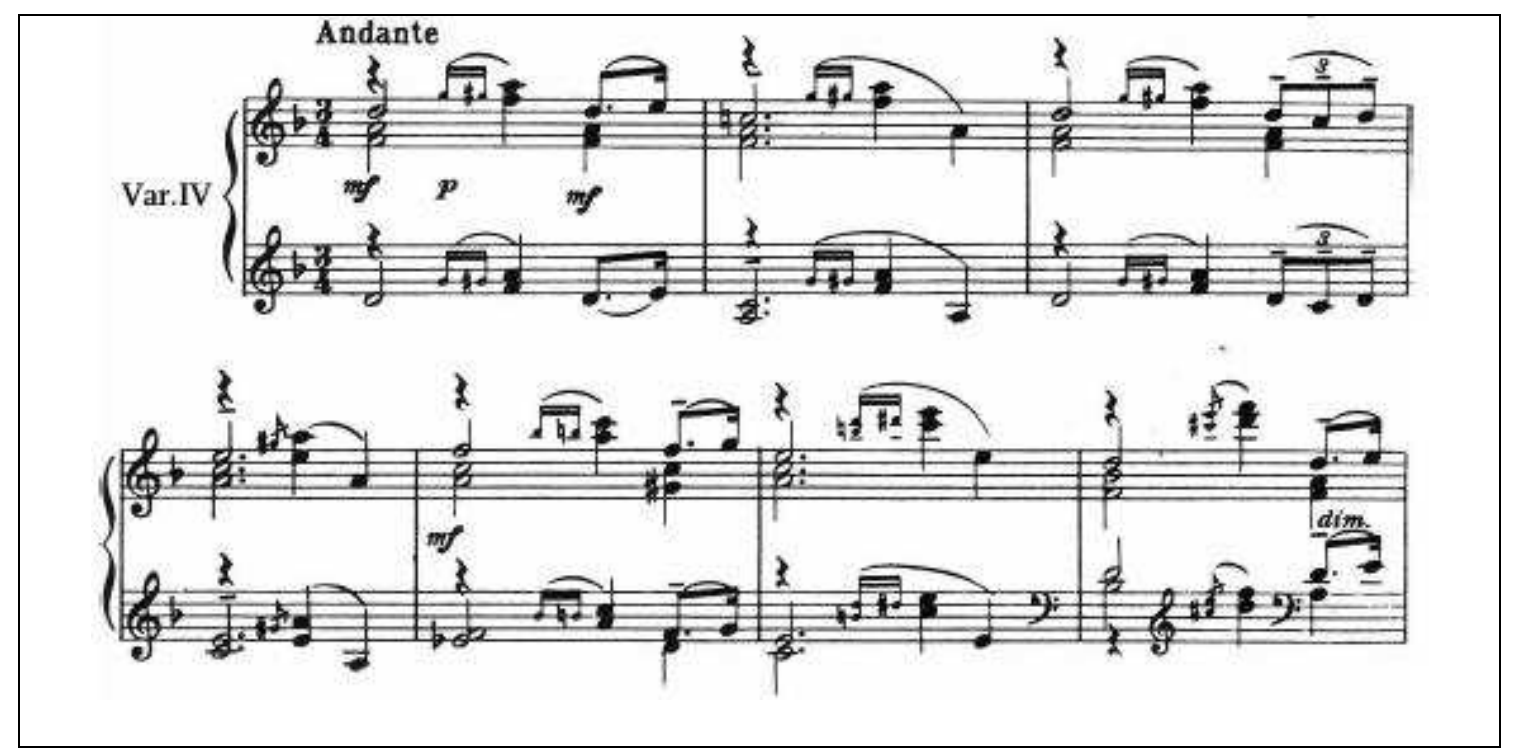

Fig.4.14: Rachmaninoff: Variações sobre um Tema de Corelli Op.42, variação IV

\footnotetext{
${ }^{25}$ No original: "I am sending you my new Variations. I've played them here about fifteen times, but of these fifteen performances, only one was good. The others were sloppy. I can't play my own compositions! And it's so boring! Not once have I played these all in continuity. I was guided by the coughing of the audience. Whenever the coughing increased I would skip the next variation. Whenever there was no coughing I would play the proper order. In one concert, I don't remember where - - some small town, the coughing was so violent that I only played ten variations (out of twenty). My best record was set in New York, where I played eighteen variations."
} 


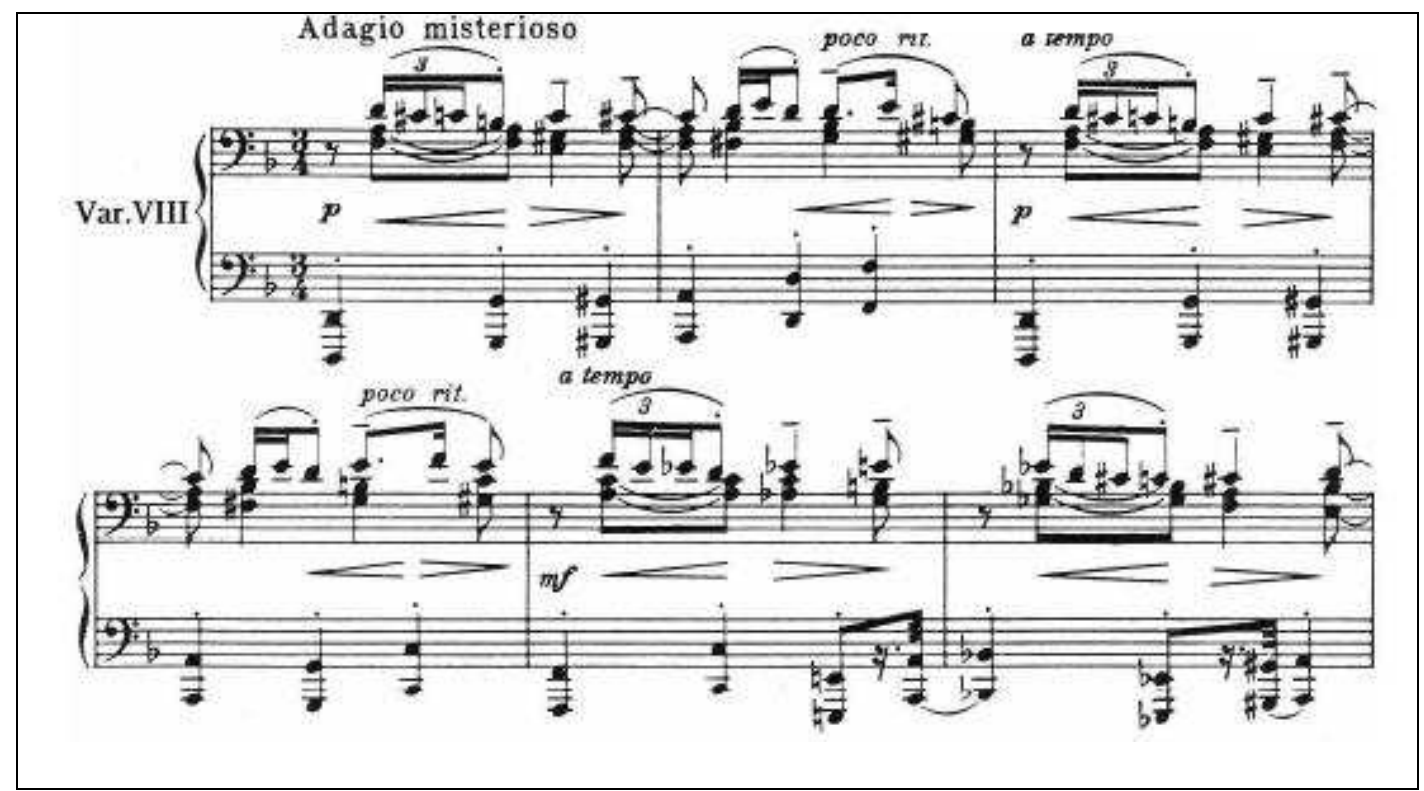

Fig.4.15: Rachmaninoff: Variações sobre um Tema de Corelli Op.42, variação VIII

As Variações Corelli podem ser agrupadas em três seções contrastantes: a) as primeiras treze variações, todas no tom de Ré menor; b) um intermezzo seguido por duas variações na distante tonalidade de Ré bemól maior ; c) as últimas cinco variações e a coda, retornando para o tom inicial.

A primeira variação mantém as harmonias do tema, apresentando a melodia no registro grave; a segunda dá continuidade ao movimento de semicolcheias da variação anterior, retornando ao registro original do tema e se tornando mais cromática. A terceira variação utiliza a transformação melódica para compactar o tema; enquanto a seguinte torna-se mais solene, retornando ao ritmo harmônico original do tema, mas com consideráveis mudanças de harmonia. A quinta marca a primeira aparição de um andamento rápido, enquanto que a sexta enriquece o aspecto harmônico do tema, continuando o movimento da variação precedente. A VII é derivada do tema e possui semelhanças com a segunda; a variação seguinte contrasta em ritmo e dinâmica com a 
anterior; a nona variação prossegue no clima misterioso da precedente, numa textura de acordes. A variação X, em caráter scherzo, é a mais improvisatória e livre em relação ao tema; a décima primeira inclui uma forte figuração rítmica que permeia o trabalho. A décima segunda variação estende o caráter rítmico das duas variações anteriores, apresentando uma figura composta de estrondosas oitavas no baixo; a XIII possui uma figura com ritmo constante ${ }^{26}$.

O intermezzo é, na verdade, uma cadência improvisatória na forma de recitativo, a fim de introduzir as duas variações que seguem no tom de Ré bemol maior. Apresentado na forma de uma fantasia livre, este interlúdio serve como um ponto de divisão no conjunto de variações. A idéia melódica básica deste interlúdio é um embelezamento com passos de semitons.

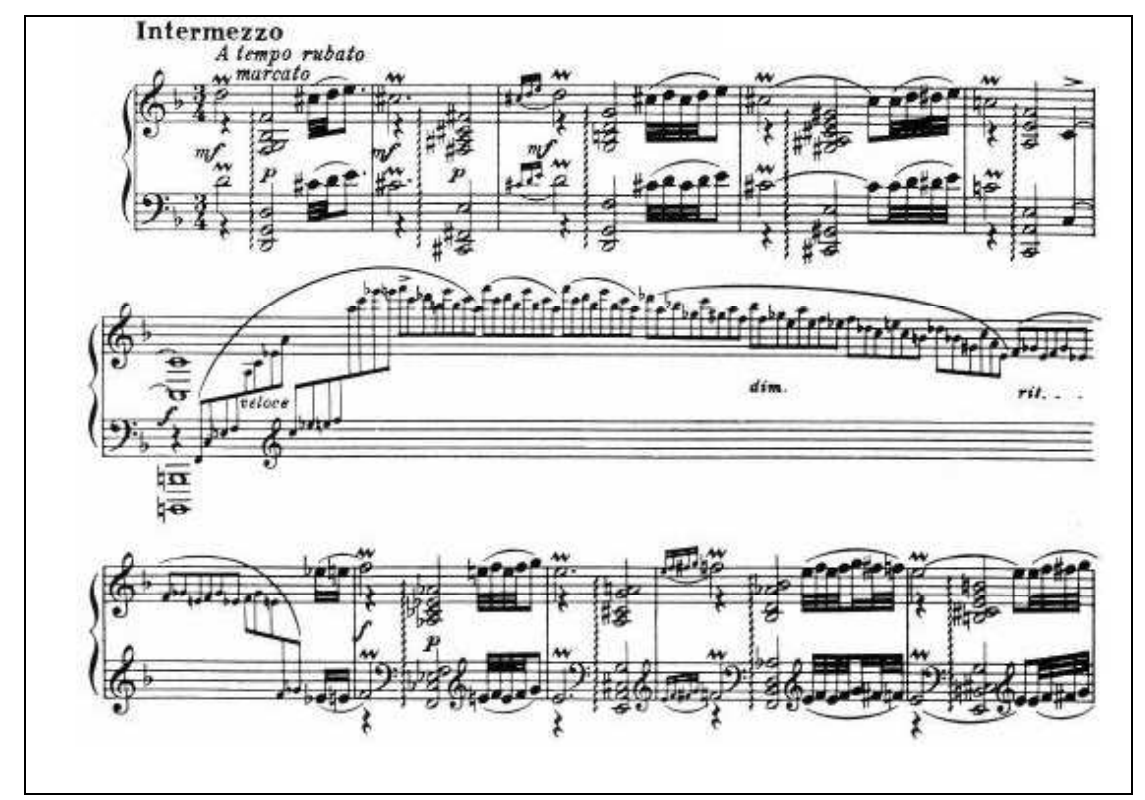

Fig.4.16: Rachmaninoff: Variações sobre um Tema de Corelli Op.42, Intermezzo

\footnotetext{
${ }^{26}$ GLOVER, 2003, pp.71-77.
} 
A variação XIV contém ricos blocos de acordes na nova tonalidade e apresenta a melodia do tema com diversos ornamentos; a décima quinta variação mantém o contorno original da melodia ${ }^{27}$.

A variação XVI retorna ao caráter rítmico apresentado nos quatro variações que precederam o intermezzo; a XVII contém harmonias muito simples e apresenta uma figuração que se expande no ritmo apresentado na variação anterior. A décima oitava variação retoma o ritmo da XIII e corresponde harmonicamente ao tema. A penúltima variação estende o modelo rítmico da anterior, mas ampliando-a para uma figuração em semifusas; a variação final continua a explorar a figura rítmica encontrada em XVIII e XIII variações, sendo a mais exigente devido aos amplos e constantes saltos. A coda retorna para uma apresentação mais lenta e melódica do tema na mão direita, acompanhada por tercinas na mão esquerda com grandes aberturas. Os últimos quatro compassos da melodia original são retomados para encerrar o ciclo ${ }^{28}$.

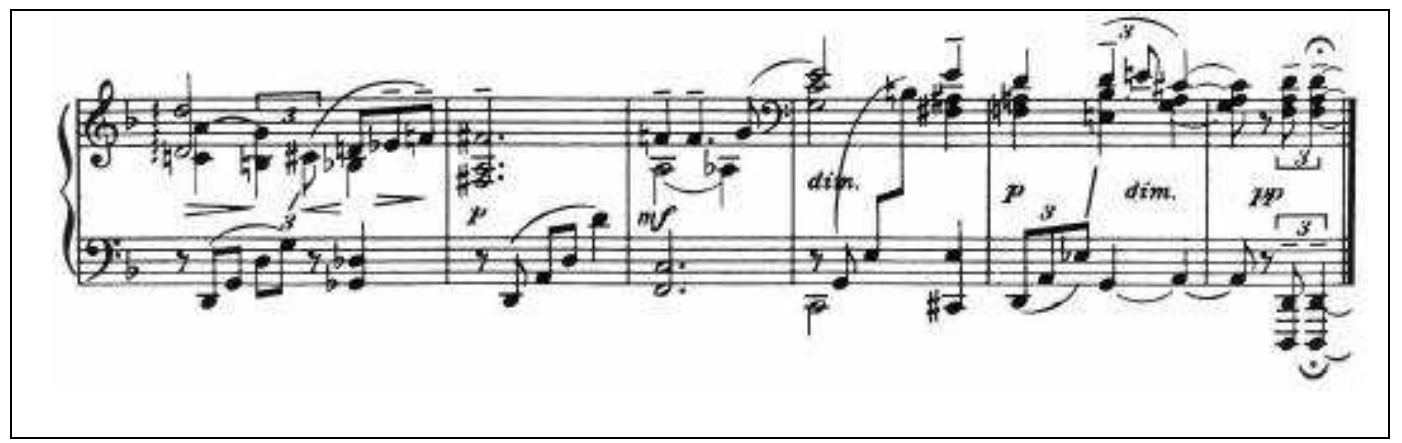

Fig.4.17: Rachmaninoff: Variações sobre um Tema de Corelli Op.42, Coda (6 compassos finais)

Como vimos, os ritmos são mais vitais do que em sua fase russa (aparente, por exemplo, na incisiva variação $\mathrm{V}$, com suas freqüentes mudanças de andamento) e as harmonias são mais ousadas e picantes, sobretudo nas variações III, VIII e IX, e na maestria

\footnotetext{
${ }^{27}$ GLOVER, op.cit., pp.78.

${ }^{28}$ Id., Ibid., pp.78-81.
} 
da modulação de Ré menor para Ré bemol maior na variação XIV, após a suavidade do intermezzo. Essas características representam um estilo mais sutil de expressão, superando o estilo bombástico dos Études-Tableaux Op.39. Assim como as últimas canções de Rachmaninoff, as Variações Corelli deixam um sentimento de pesar pelo fato do compositor russo não ter escrito outras obras para piano solo, que possibilitassem que as características atraentes deste estilo tardio se desenvolvessem plenamente ${ }^{29}$.

Se de um lado, na primeira metade do século XX, o neoclassicismo propôs novos meios de expressão estética baseados em modelos do passado, do outro houve uma tirania estética que dominou o ambiente musical no período pós-guerra, com a escola serialista de Webern e o grupo de Darmstadt. Existiu, no entanto, um grupo de compositores de oposição (Groupe Zodiaque), que negava a arte austro-germânica dominante e propôs novos caminhos para a música contemporânea, baseados na liberdade de expressão musical em face à tirania do pensamento teutônico. Um dos compositores que combateu ostensivamente essa corrente dominante em favor de uma estética transnacional e atemporal foi o compositor marroquino Maurice Ohana (1914-1992). Reconhecido como iconoclasta e individualista, Ohana foi inicialmente influenciado por Debussy e Falla, porém ampliou seu universo pesquisando, ao longo de sua vida, vários aspectos da música medieval, flamenca e africana ${ }^{30}$.

Ao rejeitar os dogmas estéticos do serialismo, o Groupe Zodiaque buscou restaurar o que eles consideravam como a legítima e natural linha de desenvolvimento de suas origens culturais, estudando a música folclórica dos países meridionais e africanos, e o repertório do cantochão e da música vocal dos séculos XIV e XV. Para Ohana, isso

\footnotetext{
${ }^{29}$ HINSON, 1982.

${ }^{30}$ RAE, 1991, p.70.
} 
significou uma investigação mais profunda sobre as formas vocal e instrumental do flamenco e do cante jondo andaluz, além da música tribal do norte da África: "Minha escrita é construída inteiramente sobre o cantochão e pela meditação e observação de minha própria música folclórica"31.

A escrita instrumental do compositor marroquino, especialmente em sua produção violonística $^{32}$, é baseada na escrita de acordes em blocos à maneira do organum, porém privilegiando os intervalos pequenos (às custas de grandes aberturas de mão esquerda), incorporando os intervalos de micro-tons como uma maneira de evocar o sonido negro do flamenco: "sons negros provocam o aparecimento do Duende - esta magia incluída no som, que nos arrebata quando aparece mas que ninguém pode definir" ${ }^{33}$. Sua música para violão, apesar da influência da cultura espanhola, não pode ser rotulada como ibérica, com exceção do Tiento, escrito para violão de dez cordas em 1955 e publicado dois anos depois. Inspirado pelas possibilidades ampliadas deste instrumento, Ohana criou uma paisagem sonora de absorção das ressonâncias profundas, alusões temáticas e originalidade. Toda a complexidade desafiadora do modernismo do século XX está plenamente representada nesse trabalho ${ }^{34}$.

O gênero tiento era originalmente a versão espanhola da toccata, apesar de sua natureza mais expressiva do que o habitual brilhantismo do estilo vistoso da toccata. Pode remeter tanto ao flamenco quanto ao repertório para a vihuela do século XVI. O Tiento de

\footnotetext{
31 OHANA, apud RAE, 1991, p.70. No original: "My writing was built entirely upon plainchant and by meditating and observing my own folk-music."

${ }^{32}$ Sua obra completa para violão inclui as obras: Tiento (1957), as suítes Si le jour paraît... (1963-64) e Cadran Lunaire (1981-82), e o concerto para violão e orquestra Três Gráficos (1957).

${ }^{33}$ Id., Ibid., p.71. No original: "[...] black sounds provoke the appearance of Duende - this magic enclosed in sound which strikes us down when it appears but which can be defined by no-one".

${ }^{34}$ WADE, 2009.
} 
Ohana é uma obra que evoca o clima espanhol numa linguagem moderna, começando com uma afirmação modernista da Folias de Espanha.

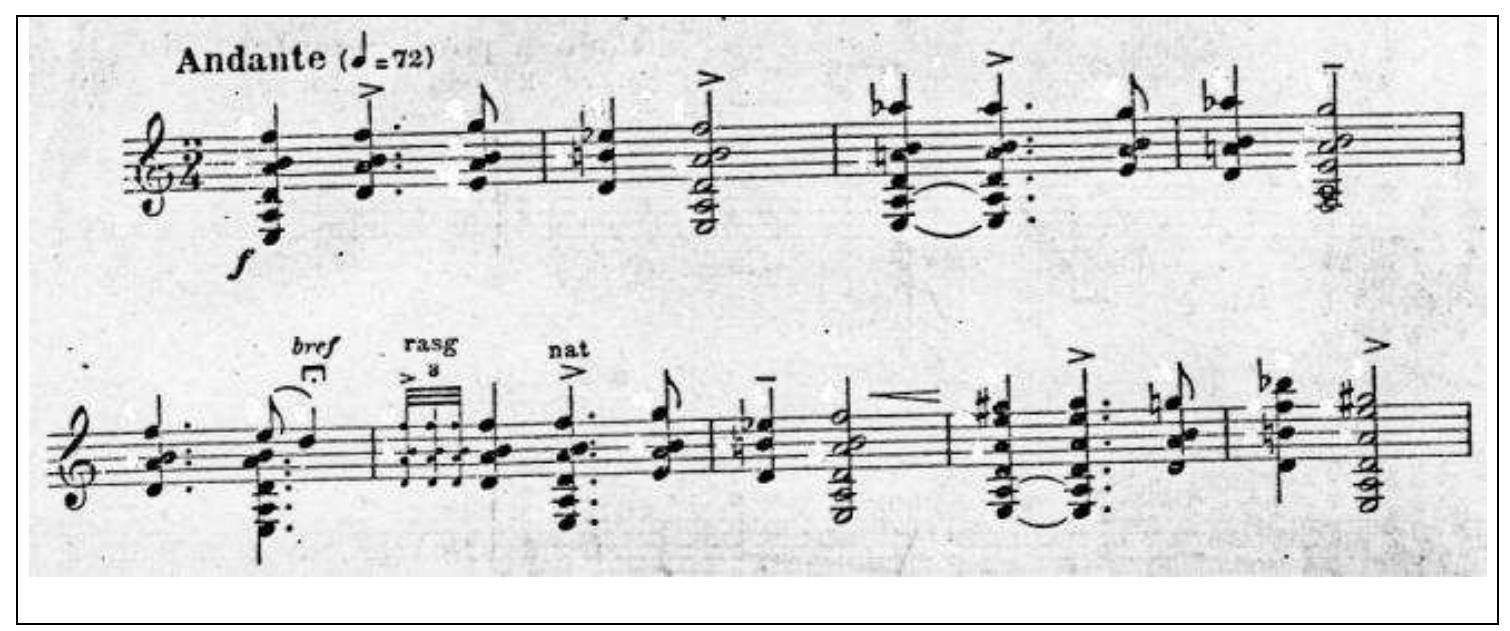

Fig.4.18: Ohana: Tiento

O desenvolvimento temático não é o da variação tradicional, embora apresente seções bem definidas, que evoca alguns padrões rítmicos da habanera, linhas melódicas internas que aludem a temas arcaicos do cantochão, um deles semelhante ao Dies Irae.

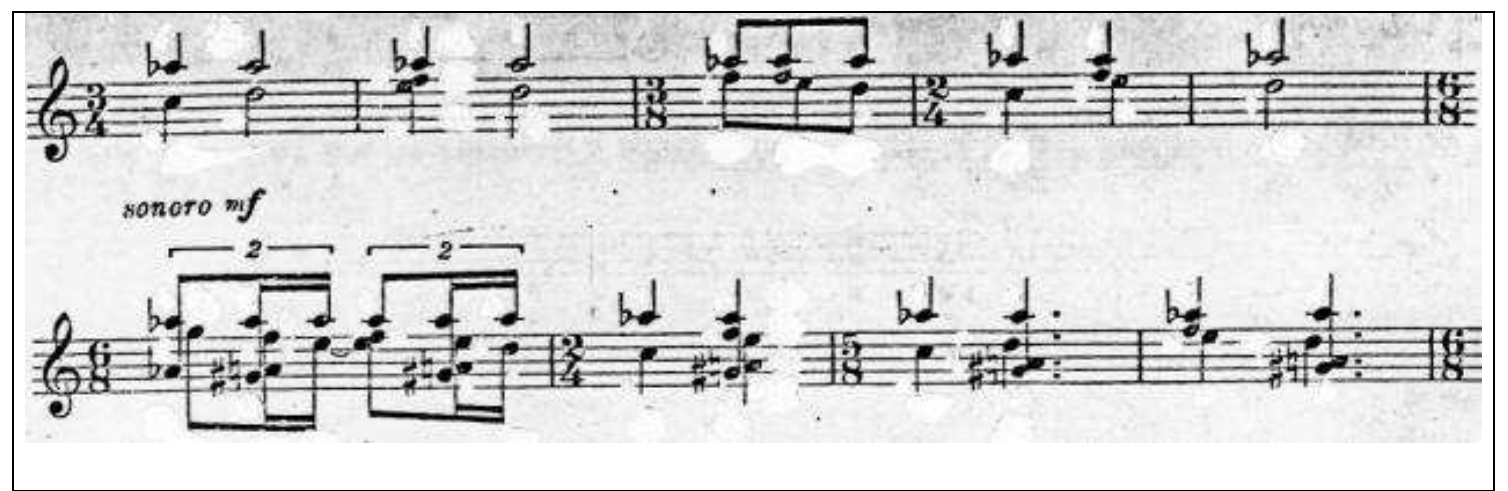

Fig.4.19: Ohana: Tiento (referência ao Dies Irae)

É também possível reconhecer citações de Falla, como a Homenaje Pour le Tombeau de Debussy e o tema do movimento central do Concerto para Cravo. Essas 
referências são habilmente articuladas em conjunto e a peça termina com um pedal sobre a dominante com um sinistro toque de tambor.

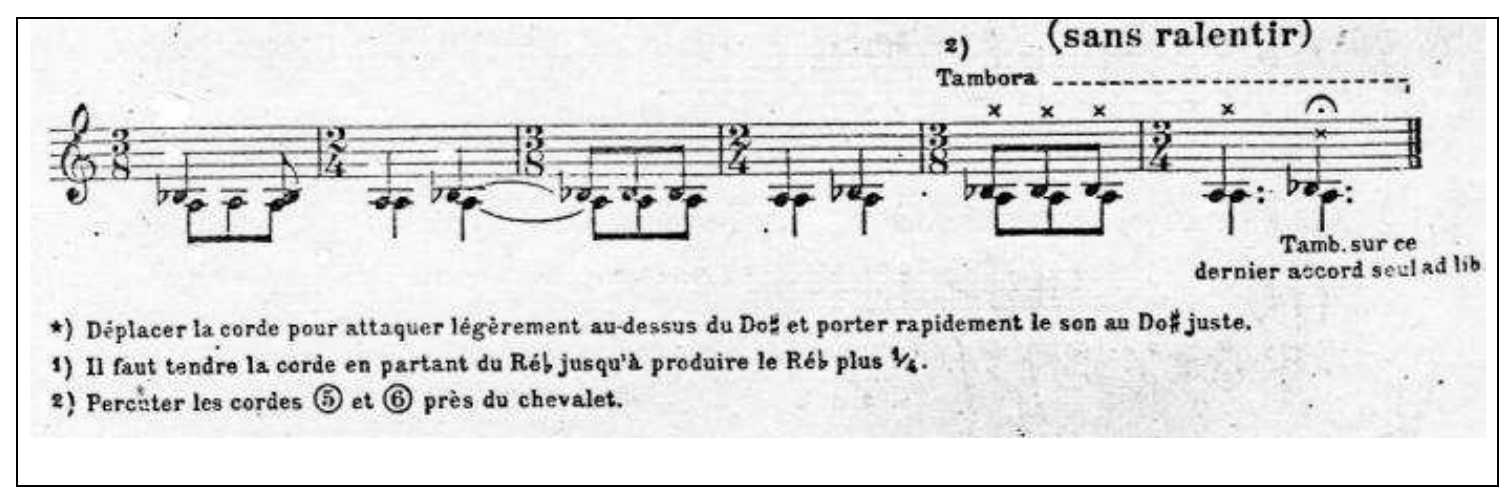

Fig.4.19: Ohana: Tiento (compassos finais) 


\subsection{Interdisciplinaridade: a Folias de Espanha no cinema}

De acordo com Ney Carrasco, o surgimento do cinema separou duas eras, em que a produção artesanal foi substituída pela produção industrial e reprodutível da cultura de massa. Embora o cinema não tenha efetivamente inaugurado as relações entre a música e as outras linguagens, a complexa linguagem cinematográfica herda uma tradição secular da cultura ocidental. Nela, há diversas manifestações em que a música dialoga com a fala, com a estrutura dramática, com o gesto, com a ação e com o movimento. O cinema e a música possuem muito em comum, o que leva as pessoas a relacioná-los, mesmo que intuitivamente ${ }^{35}$.

Se admitirmos que as relações entre música e cinema são quase intrínsecas, podemos afirmar que o épico Barry Lyndon, lançado em 1975, com direção de Stanley Kubrick e fotografia de John Alcott representa a maior variação de Folias de Espanha do século XX. Baseado no romance As memórias de Barry Lyndon, escudeiro de William Marketplace Thackeray ${ }^{36}$, publicado em 1840, narra as memórias da personagem Redmond Barry em sua frustrada tentativa de ascensão social durante o antigo regime. Ambientado no século XVIII, o filme é uma meditação sobre a transitoriedade da vida e conta com a medida majestosa em seus perfeitos enquadramentos, que remetem às pinturas da época. Além disso, possui uma narrativa metalinguística que cria surpreendentes relações de conteúdo a partir dos diálogos travados entre as matrizes verbal, sonora e visual.

O romance de Thackeray é um relato cínico sobre a ascensão e queda na escalada social. Embora Kubrick não tenha sido fiel ao plot do livro - há diversos episódios cortados e outros adicionados, uma vez que o filme trabalha mais no âmbito da representação

\footnotetext{
${ }^{35}$ CARRASCO, 2003, p19.

${ }^{36}$ THACKERAY, 2004.
} 
estética do que da fidelidade temática - ele o foi em relação ao cinismo da idéia central e, a partir dela, construiu um complexo discurso cinematográfico. Kubrick sacrificou o drama, a psicologia e a narrativa em prol do efeito visual, pois sua meta foi ressaltar a transitoriedade da vida das personagens. Em Barry Lyndon, escudeiro, Thackeray estava experimentando a estética da paródia sobre o estilo de Daniel Defoe $(1660-1731)^{37}$, satirizando o sentimentalismo da novela confessional em primeira pessoa: a auto-exposição de Redmond não passa de um discurso formal sobre sua vida. Kubrick, por sua vez, encontrou nesse roteiro a oportunidade para o perfeito equilíbrio cinematográfico entre forma e conteúdo, pois para ele, "Eisenstein é todo forma sem conteúdo, enquanto Chaplin é conteúdo sem forma" ${ }^{38}$.

Dentro da estrutura em duas partes do filme, Kubrick introduz narrativas adicionais em três eixos temáticos recorrentes: duelos, jogos de cartas e pagamentos de dívidas. Essas atividades possuem um sentido metafórico como extensões dramáticas do destino: vidas desperdiçadas em duelos motivos banais; a passagem do tempo e a consciência de sua brevidade nos jogos de cartas; rituais sociais aristocráticos retratados nos pagamentos de dívidas.

Barry Lyndon revela a cisão entre as atividades humanas e suas formas de expressão congeladas na arte e na história. Assim, o filme interpreta e transcende uma era através da exploração e dramatização dos vários níveis da compreensão e percepção, emoção e ironia, comédia e tragédia, história e arte. Um exemplo dessa transcendência é a última frase do narrador que diz "hoje são todos iguais" (que, no romance, localiza-se ao início ${ }^{39}$, mudando

\footnotetext{
${ }^{37}$ Escritor e jornalista inglês, famoso pelo romance Robinson Crusoé.

${ }^{38}$ KUBRICK apud NELSON, 1979, p.46.

${ }^{39}$ THACKERAY, 2004, p.9.
} 
completamente seu significado e sua força), na qual percebemos a busca de Kubrick em preservar na arte a idéia de resistência ao tempo.

Ao invés de ter dado voz ao protagonista como em Lolita e Laranja Mecânica, Kubrick introduziu um narrador (Michael Hordern) cuja onisciência está limitada aos fatos e circunstâncias da estória; além dela, ele não tem nada a nos dizer. Ele até sublinha certas inconsistências entre as aspirações pessoais e a sorte do destino, mas nunca o conteúdo emocional das personagens: estas estão manifestas primordialmente na música e nas imagens da complexa manipulação cinematográfica de Kubrick. O narrador tece comentários cínicos sobre as personagens, como se soubesse muito sobre o aspecto exterior e pouco sobre a psicologia das personagens. Um dos exemplos está na narração na cena de despedida de Barry (Ryan O'Neal) com a camponesa Lischen (Diana Körner), cuja realidade emocional e temporal revelada pela beleza das imagens - com fotografia intimista que remete a um ambiente idílico de encantamento romântico - entra em choque com a ironia machista da fala do narrador: "uma donzela que deposita seu amor em um homem de uniforme precisa estar preparada para mudar de amantes rapidamente, ou sua vida será insuportável". Na Parte I, seu tom é irônico e nos alerta sobre o destino e a sorte das personagens (perspectiva do futuro); na Parte II é trágico e antecipa os fatos cruciais da estória (consciência passada).

O jogo de câmera procura aproximar-se da percepção de tempo do século XVIII, tornando-se mais lenta e estática na segunda parte do filme, transformando os atores em verdadeiras pinturas:

Tal método sugere visualmente o aprisionamento inconsciente de Barry Lyndon em um mundo que se comunica através da dinâmica de uma linguagem social rígida e decorativa [...] Barry não percebe sua própria diminuição e aquela de 
uma sociedade que apenas sabe criar para si própria belas e atraentes prisões. (NELSON, op.cit., p.47-48). ${ }^{40}$

O aprisionamento aos códigos sociais são retratados com tanto rigor, que até mesmo uma cena como o assalto do Capitão Feeney (Arthur O'Sullivan) pode ser enquadradado como um sofisticado ritual, em estilo retoricamente alto. Outro exemplo é a cena do Príncipe de Tübingen (Wolf Kahler) que acusa o Chevalier Balibari (Patrick Magee) de roubar no jogo de cartas, com uma fala extremamente vagarosa. É como se as imagens tentassem escapar do fluxo do tempo transformando-se em pinturas.

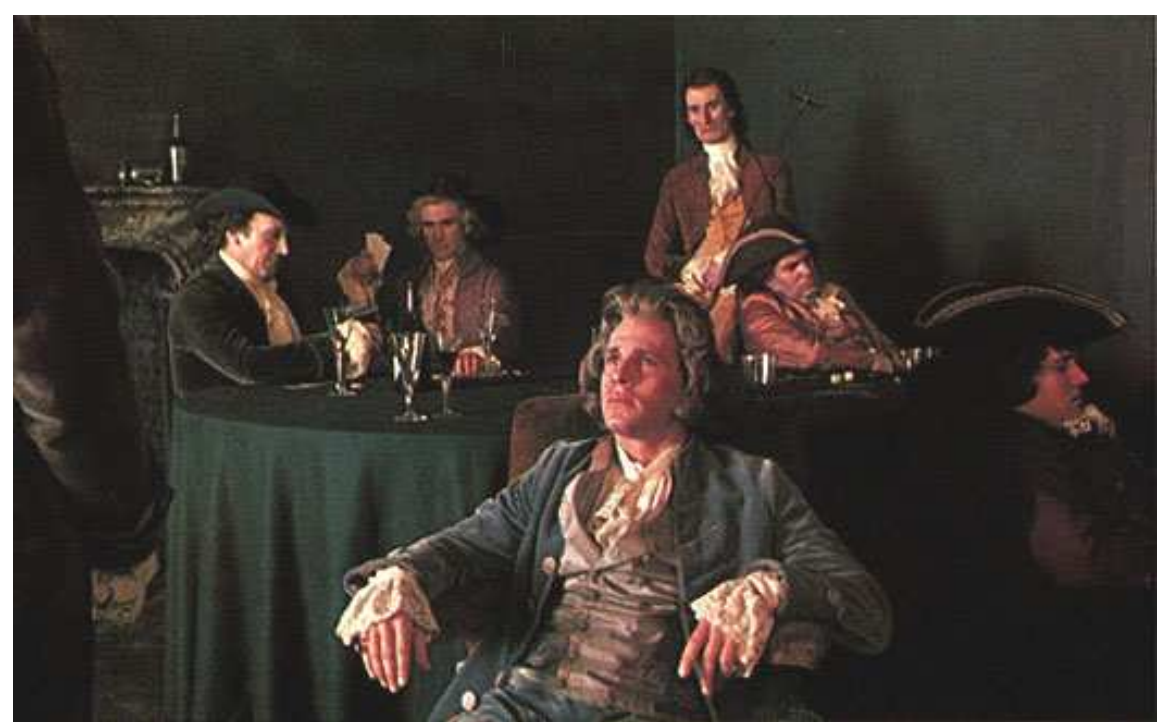

Fig. 4.21: Kubrick\& Alcott: Barry Lyndon: exemplo de imagem estática que predomina no filme

Outro procedimento que manipula a recepção do espectador é a forma de uso da técnica de enquadramento, privilegiando o zoom reverso ${ }^{41}$. Esse procedimento redimensiona a humanidade numa perspectiva atemporal, ressaltando sua evanescência. $\mathrm{O}$ efeito resultante desse procedimento faz com que o espectador observe os fatos do

\footnotetext{
${ }^{40}$ No original: "Such a method visually suggests Barry Lyndon's unknowing entrapment in a world which communicates through the dynamics of a rigid and decorative social language [...] Barry does not perceive is his own diminution and that of a society which only knows how to make for itself beautifully attractive cages."

${ }^{41}$ Procedimento visual que parte do close, ou plano médio, e se afasta gradualmente para os planos amplos.
} 
particular para o geral, representando dessa forma um mundo que diminui e ao mesmo tempo engole as ambições pessoais. Um dos erros fatais de Barry Lyndon foi não perceber as disparidades entre suas origens e sua ambição, faltando-lhe maturidade para transcender seu próprio destino. Se, por um lado, o jogo de câmera denuncia essa falta de percepção no zoom reverso, por outro, a câmera de mão é utilizada nas cenas de maior intensidade, como na luta de punho com o soldado e na briga no salão, criando um forte contraste com a visão pitoresca que domina o filme, envolvendo o espectador num novo tipo de dinâmica que suspende temporariamente a consciência da passagem do tempo.

$\mathrm{Na}$ segunda parte do filme, a manipulação do tempo efetuada pelo diretor passa a ser um elemento fundamental. Nos é permitido experimentar, através de informações temporais precisas, um crescimento emocional no caráter de Redmond muito mais evidente que no romance de Thackeray, mas que tragicamente chega tarde demais. Se na primeira parte não sabemos exatamente quanto tempo cada cena retrata (não é possível saber quantos dias Barry passou com a camponesa, nem onde eles estavam), a segunda parte é constantemente marcada por datas: logo na primeira cena, do casamento, o narrador fornece a primeira datação, 15 de junho de 1773 . É como se o diretor estivesse iniciando uma contagem regressiva para Barry Lyndon que, em seu auge, irá agora jogar uma partida de azar contra o tempo, numa sucessão acontecimentos infelizes: deterioração do casamento, luta pelo título de nobreza, morte do filho, duelo com Lord Bullington (Leon Vitali), etc. O que não deixa de ser mais uma ironia, pois à medida que se elevam o caráter e emoção de Barry, seu mundo social desmorona.

A Parte II revela novos aspectos irônicos na escolha de determinados cenários: a igreja abandonada que serve de palco para o duelo com Lord Bullington não apenas evoca as origens rurais de Barry, mas é local onde ele demonstra um gesto de verdadeira 
dignidade (perder propositalmente seu tiro contra o enteado no duelo), além do fato de que é a única cena em que o protagonista age conscientemente, sem acompanhar os revezes do destino.

Em contraste ao amadurecimento emocional de Barry, à medida que sua esposa (Marisa Berenson), "H. Lyndon" ${ }^{42}$, se torna um motivo visual mais dominante no filme, Kubrick deixa claro que nada restou daquele passado para nos informar sobre a miríade de realidades pessoais de uma determinada época, a não ser os documentos assinados por ela. Ou seja, ninguém possuía de fato uma individualidade no antigo regime, o que levou o crítico Thomas Allen Nelson afirmar que:

A interpretação de Kubrick do final do século XVIII sugere uma crença numa armadilha trágica de um período dentro de seu próprio formalismo racional e mecânico. Ele personifica através de Barry Lyndon a separação entre a vida racional e emocional comum à dependência do século sobre as formas da razão e os medos da imaginação individual; à uma época que buscou obsessivamente manter as formas do seu mundo às custas de sua vitalidade moral e emocional; de uma época que temia a sua própria mortalidade e encontrava refúgio em qualquer quimera do ritual social ou nas incompreendidas formas de arte. Kubrick sugere que apenas os artistas do século XVIII escaparam a esta decorada prisão de pelúcia, não necessariamente através da atribuição de profundo conteúdo em suas diversas realizações artísticas, mas porque o gênio de homens como Bach e Mozart, Gainsborough e Hogarth, forneceu à posteridade aquela sensação de estímulo que enriquece a vida interior e suspende as forças da estupidez e da tirania, que, em todos os níveis da vida social e psicológica, ameaçam a capacidade do indivíduo para uma experiência profunda. (NELSON, op.cit., p.49). ${ }^{43}$

\footnotetext{
${ }^{42}$ Kubrick costuma moldar as personagens de seus filmes com um cuidado obsessivo, entretanto, na construção de Lady Lyndon, não temos acesso a seu mundo interior, pois sua presença é um ícone quase mudo, da qual se conhece apenas a inicial do prenome "H". Seu nome Honoria só nos é conhecido pela fonte literária (cf. THACKERAY, 2004, p.186).

${ }^{43}$ No original: "Kubrick's interpretation of the late 18th century suggests a belief in a period's tragic entrapment within its own rational and mechanical formalism. He embodies throughout Barry Lyndon that divorce between rational and emotional life common to that century's reliance upon forms of reason and fears of individual imagination; to an age which obsessively sought to maintain the forms of its world at the expense of its moral and emotional vitality; of an age which feared its own mortality and found refuge in either the chimera of social ritual or the uncomprehended forms of art. Kubrick implies that only the artists of the 18th century escaped this plush and painted cage, not necessarily through the injection of profound content into their various artistic achievements, but because the genius of men like Bach and Mozart, Gainsborough and Hogarth, provides later epochs with that sense of exhiliration which enriches the inner life and counters those forces of stupidity and tyranny which, on all levels of social and psychological life, threaten the individual's capacity for profound experience".
} 
Um dos atributos mais notáveis de Barry Lyndon é o alto nível de referência visual para a reconstrução de uma época, que insufla vida às personagens. A fotografia de Alcott é, literalmente, uma pintura com luzes naturais em todo o filme: as imagens possuem extraordinária clareza e profundidade, remetendo-nos aos quadros de Hogarth e Gainsborough, não pela simples narrativa visual, mas no próprio ambiente moral e intelectual do século XVIII.

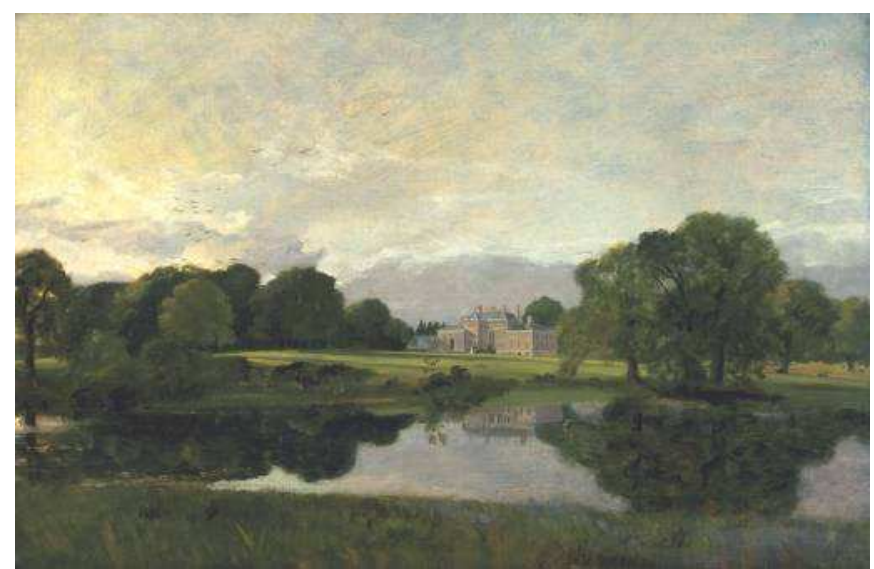

Fig.4.22: John Constable: Malvern Hall, Warwickshire, 1809.

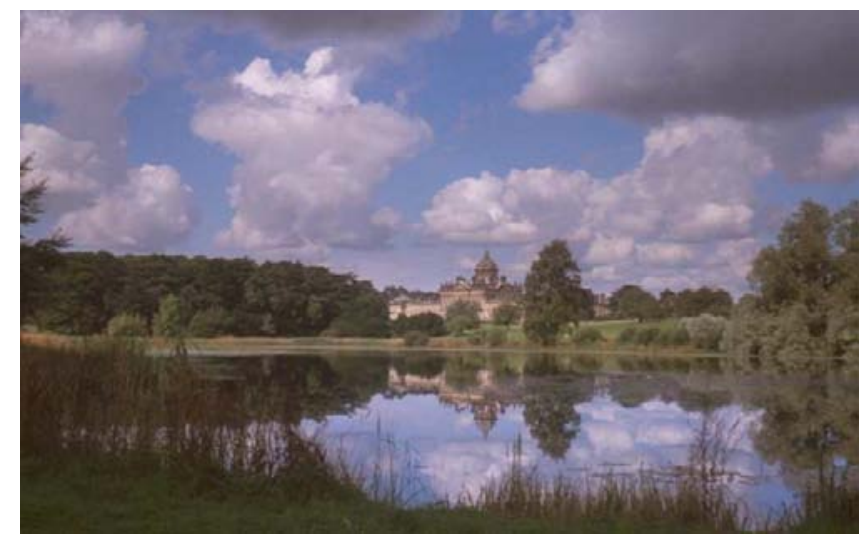

Fig.4.23: Kubrick \& Alcott: Barry Lyndon

A escolha da trilha sonora nos filmes de Kubrick é extremamente meticulosa no sentido de agregar novos significados, além de antecipar fatos e informar o espectador sobre o universo afetivo das personagens. A versão orquestral da Sarabande de Haendel em 
Barry Lyndon, com sua pulsação regular e sonoridade arcaica, resulta numa fusão das linguagens plenamente afinada com a narrativa visual que ostenta a regularidade barroca, produzindo uma grandiosidade formal que redefiniu os parâmetros prevalecentes do gênero épico de filme. Podemos afirmar que a Sarabande é o tema principal do filme, emoldurando-o tanto na abertura quanto nos créditos finais, e que a peça ficou tão associada ao filme quanto o poema sinfônico de Richard Strauss Assim Falou Zaratustra (1896) ao 2001: Uma Odisséia no Espaço (1968). Seu significado é múltiplo, começando pela sua evidente associação à temática da morte: o tema está presente nos dois duelos (Capitão Quinn e Lord Bullington) e na morte de Brian, marcando também duas grandes viradas no destino de Barry (fuga da Irlanda e despojamento de Barry da família Lyndon). Ao mesmo tempo, devido ao aspecto de eternidade imanente à Sarabande e, por extensão, ao caráter de atemporalidade da Folias de Espanha, percebemos que a música não apenas evidencia o eixo temático dos duelos, mas também aponta para o fato de que a humanidade nunca foi capaz de transcender seu próprio destino, uma vez que os duelos foram passados de uma geração a outra.

Outro aspecto de montagem interessante no diálogo entre imagem e som é que os temas musicais antecipam algumas cenas, como na cena da tragédia com o cavalo que mata o filho de Barry: tanto o narrador (dizendo que Barry não deixou herdeiros) quanto o reaparecimento da Sarabande (durante o jantar em que Brian agradece o presente) tornam demasiadamente evidente que a criança não iria viver. Portanto, o tema assume também uma importante função temporal ao pontuar o destino.

Os outros temas musicais podem ser classificados em três gêneros básicos de música, que também reforçam a divisão das camadas sociais: 
a) Rústico: melodias de caráter modal que pontuam os amores juvenis de Barry Lyndon e alguns fatos relacionados às suas origens, como a dança no campo, sua viagem e o assalto do Capitão Feeney. Exemplos: Piper's Maggot Jig e The Sea Maiden (melodias tradicionais); Women Of Ireland e Tin Whistles de Sean O'Riada;

b) Militar: marchas tradicionais e estilizadas sinfonicamente, que ilustram as fases da vida de Barry Lyndon nos exércitos britânico e prussiano, e durante a espionagem do Chevalier Balibari. Exemplos: Hohenfriedberger (Frederico, o Grande), Marcha de Idomeneo (Mozart), Cavatina do Barbeiro de Sevilha (Paisiello), Lilliburlero e British Grenadiers (melodias tradicionais). Esta última também é cantada pelos aristocratas na cena de luxúria, evidenciando que o repertório musical militar era um bem compartilhado entre nobreza e povo ${ }^{44}$.

c) Galante: obras do repertório culto de usufruto da classe aristocrática, marcando alguns personagens, a convivência familiar e certos eventos sociais. Exemplos: Trio em Mi bemól maior, Op.100 (Schubert), Concerto para Violoncelo em Mi menor (Vivaldi), Concerto para Dois Cravos em Dó menor (Johann Sebastian Bach).

Um aspecto que unifica todas as músicas do filme é que todas possuem estrutura circular, sem desenvolvimento. Talvez esse detalhe de escolha musical também seja indicativo de que o diretor quisesse nos revelar, por meio dessas obras, um universo sonoro que refletisse uma sociedade anacrônica, ainda presa às convenções do passado, afinal os compositores da segunda metade do século XVIII já exploravam o desenvolvimento como uma nova forma discursiva na música.

\footnotetext{
${ }^{44}$ Cf. o conceito de Circularidade Cultural exposto no capítulo 1.1.
} 


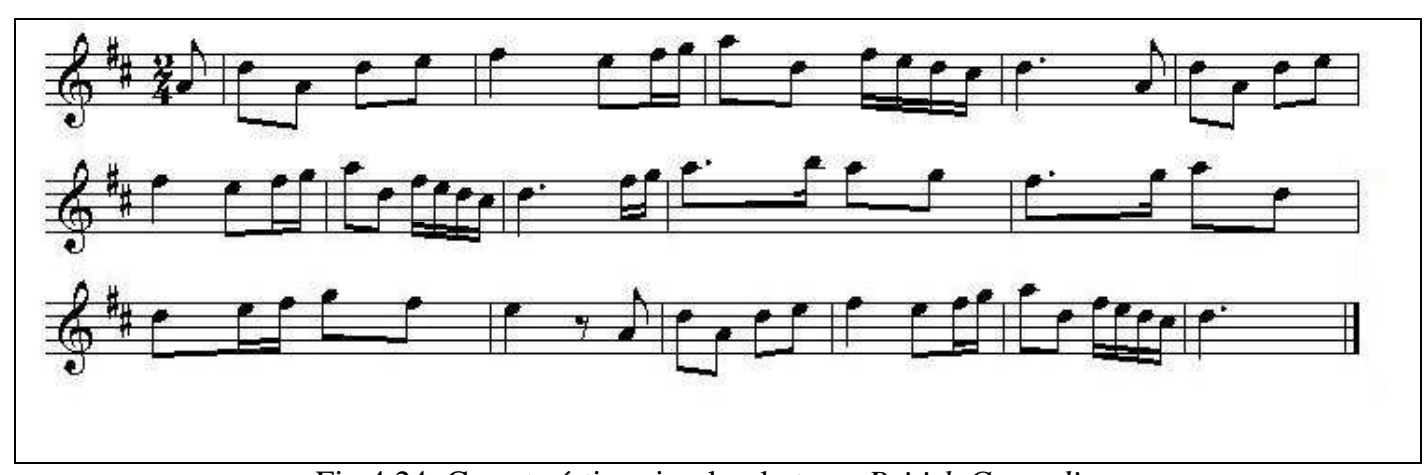

Fig.4.24: Característica circular do tema British Grenadiers

Da mesma forma que analisamos o uso da Folias de Espanha como elemento subtextual $^{45}$, Kubrick percebeu o potencial da versão haendeliana e também a utilizou como elemento metalingüístico. Talvez não seja possível sabermos se o cineasta americano possuía algum tipo de conhecimento sobre a historicidade da Folias de Espanha, o que é irrelevante quando considerarmos o mais importante: o alto nível de elaboração na construção de narrativas - ao invés de uma mera citação vazia, presente em artistas do nível de Bach, Beethoven e Brahms.

Outro exemplo marcante de montagem em dialogar com a trilha sonora é a impressionante composição criada para o duelo final: um ritual elaborado, decoroso na aparência e mortífero na essência. O tema da Sarabande antecipa o duelo na cena anterior, com a marcação do ritmo nos tímpanos, revelando desde antes toda a ambientação de terror que permeará a cena seguinte. A maneira como Kubrick suspende a tensão durante duelo, por quase dez minutos, já é um procedimento tipicamente romântico: o diretor constrói a cena metodicamente, levando o espectador a uma sensação de quase-eternidade.

A escolha do Andante con moto do Trio Op.100 de Schubert possui a mesma característica de pulsação regular da Sarabande de Handel, mas pontuando um novo

\footnotetext{
${ }^{45}$ Cf. os capítulos 2.7 e 3.2 .
} 
aspecto, não circular mas evolutivo. A cena final da assinatura de Lady Lyndon da pensão vitalícia de Barry Lyndon é um exemplo magistral de junção entre imagem e música, sem falas, apenas na sincronia perfeita dos olhares, assinatura e tomada de plano fundo com a música de Schubert. Um detalhe relevante no close da ordem de pagamento desta cena é a datação do documento, dezembro de 1789, que não aparece no romance de Thackeray: a escolha do ano da Revolução Francesa para finalizar o filme parece remeter ao início de uma nova era na Europa, na qual seus protagonistas antigos se reduziram a meros documentos ou foram encapsulados em pinturas.

Kubrick termina o filme com uma pungente imagem congelada de Redmond de costas, como uma metáfora para o declínio pessoal e a perda da batalha do ser humano contra o tempo e seu aprisionamento aos rituais criados por uma sociedade que valorizava mais o decoro do que a própria vida. Talvez o cineasta esteja sugerindo que as disparidades entre os diferentes períodos da história humana podem ser casos particulares de uma condição universal.

Outro filme, de tendência mais comercial e de menor profundidade, é o 1492 Conquista do Paraíso, com direção de Ridley Scott e trilha sonora do compositor grego Evangelos Odysseas Papathanassiou (nascido em 1943), que adotou o apelido artístico de Vangelis. A contribuição deste épico, que ilustra a viagem de Cristóvão Colombo (Gerhard Depardieu) à América, foi ter propiciado o resgate definitivo da popularidade da Folias de Espanha no século XX, iniciada com Barry Lyndon, uma vez que o filme e sua trilha tiveram um impacto comercial de proporções mundiais. O tratamento da Folias de Espanha, dentro poética de Vangelis, é bastante simples, utilizando um acompanhamento percussivo em ritmo ostinato (dáctilo) e um coro masculino, cujo efeito traz ao mesmo tempo um ethos de antiguidade e heroísmo: 


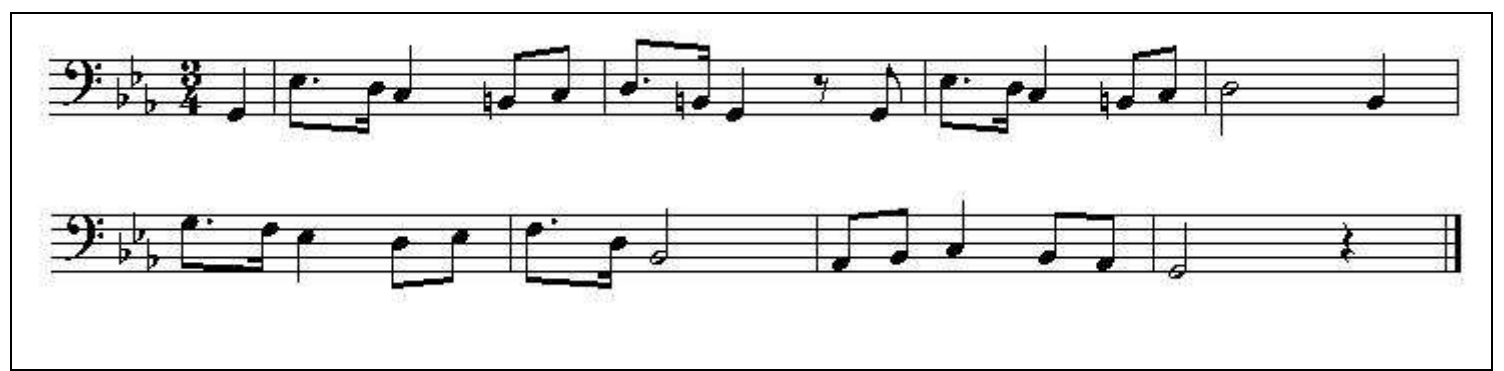

Fig.4.25: Vangelis: tema Conquest of Paradise

A partir da estréia do filme Conquista do Paraíso, o tema Folias de Espanha cresceu exponencialmente como tema para variações, além de outras formas musicais e em novas inserções cinematográficas. O tema de Vangelis também se fixou no imaginário da cultura popular, sendo utilizado recorrentemente diversos e variados contextos, não apenas midiáticos, com seu espaço definitivamente consolidado dentro do repertório clássico ligeiro. 


\subsection{Pós-Modernidade e as novas sonoridades da Folias de Espanha}

O filósofo britânico Terry Eagleton considera que a Pós-Modernidade é uma linha de pensamento que questiona as noções clássicas de verdade, razão, identidade e objetividade, a idéia de progresso ou de emancipação universal, os sistemas únicos, as grandes narrativas e os fundamentos definitivos de explicação ${ }^{46}$.

O pós-modernismo vê o mundo como contingente, gratuito, diverso, instável, imprevisível, um conjunto de culturas ou interpretações desunificadas gerando um certo grau de ceticismo em relação às idiossincrasias e à coerência de identidades. É um estilo de cultura que supera os parâmetros modernistas por meio de uma arte superficial, descentrada, infundada, auto-reflexiva, divertida, caudatária, eclética e pluralista ${ }^{47}$.

A cultura pós-moderna produziu - e continua produzindo - um conjunto de obras ricas, ousadas e divertidas, em todos os campos da arte, derrubando certezas inabaláveis, contaminando purezas protegidas e transgredindo normas opressoras.

O pós-modernismo constitui um fenômeno tão híbrido, que qualquer afirmação sobre um aspecto dele quase com certeza não se aplicará a outro. Numa visão mais sociológica do mesmo fenômeno cultural, o crítico literário Fredric Jameson ${ }^{48}$ propõe que a Pós-Modernidade - também conhecida por outros tipos de generalização sociológica, como sociedade "pós-industrial”, “de consumo", “das mídias”, etc. - é caracterizada, dentre outras coisas, por uma autoconsciente ruptura com os elementos do Modernismo, que foi canonizado na década de 50. Sua estética incorpora aspectos empíricos, caóticos e heterogêneos, além de enfraquecer a clássica fronteira entre alta cultura e cultura de massa,

\footnotetext{
${ }^{46}$ EAGLETON, 1998, pp.7-9. O mesmo autor faz uma distinção entre os termos pós-modernismo (uma forma de cultura contemporânea) e Pós-Modernidade (que se refere a um período histórico específico).

${ }^{47}$ Id., Ibid., p.35.

${ }^{48}$ JAMESON, 2002, pp.27-52.
} 
uma vez que "qualquer ponto de vista a respeito do pós-modernismo na cultura é ao mesmo tempo, necessariamente, uma posição política, implícita ou explícita, com respeito à natureza do capitalismo multinacional em nossos dias" ${ }^{49}$.

Para Linda Hutcheon, a Pós-Modernidade resgatou a função comunicativa perdida na tirania estética do Modernismo por meio da paródia (embora Jameson e Hutcheon utilizem terminologias diferentes - paródia e pastiche, o fenômeno descrito é o mesmo):

Talvez a paródia tenha chegado a ser uma modalidade privilegiada da autoreflexividade formal do pós-modernismo porque sua incorporação paradoxal do passado em suas próprias estruturas muitas vezes aponta para esses contextos ideológicos de maneira um pouco mais óbvia, mais didática, do que as outras formas. A paródia parece oferecer, em relação ao presente e ao passado, uma perspectiva que permite ao artista falar para um discurso a partir de dentro desse discurso, mas sem ser totalmente recuperado por ele. Por esse motivo, a paródia parece ter se tornado a categoria daquilo que chamei de 'ex-cêntrico', daqueles que são marginalizados por uma ideologia dominante. [...] Tanto para os artistas quanto para suas platéias, a paródia estabelece uma relação dialógica entre a identificação e a distância. Assim como a Verfremdungseffekt [efeito de distância] de Brecht, a paródia funciona para distanciar e, ao mesmo tempo, envolver o artista e a platéia numa atividade hermenêutica de participação. (HUTCHEON, 1991, p.58).

Em vista dos novos parâmetros da estética da comunicação musical, e da revalorização do pastiche como um recurso possível de ser encarado seriamente pela teoria e crítica da Pós-Modernidade, temos hoje um repertório contemporâneo que atravessa os estilos históricos evocando não apenas sonoridades passadas de uma maneira mais embasada, sobretudo dentro do movimento da performance histórica associada à musicologia ${ }^{50}$, mas também por meio da revisitação de temas antigos com um tratamento mais contemporâneo, ou simplesmente imitações e emulações descompromissadas de grandes temas do passado. A tecnologia, tanto na recuperação de instrumentos antigos

\footnotetext{
${ }^{49}$ JAMESON, 2002, p.29.

${ }^{50}$ KERMAN, 1987, pp.255 et seq.
} 
quanto na criação e síntese de novos timbres, normalmente é empregada como elemento criativo ou de suporte.

Ao lado dessa nova poética contemporânea, o violão clássico da grande tradição Tárrega-Llobet-Segovia tem sobrevivido e se adaptado às novas sonoridades da PósModernidade. Assim, não é de se estranhar que o repertório violonístico contemporâneo que possuía uma tradição bem estabelecida com as variações de Sor, Giuliani, Llobet e Ponce - continuou a contribuir com a incessante inclusão de "novas" variações sobre a Folias de Espanha. Podemos até falar da existência de uma categoria de repertório exclusiva, embora a maior parte esteja calcada na emulação do estilo barroco "alla Corelli" que não foge do lugar comum - retornaremos a essa discussão mais adiante.

Das obras recentes compostas dentro desta categoria, destacamos algumas da mesma época, entre 1989 e 1990, que possuem algum tipo de interesse por explorar novas sonoridades que, embora não apresentem uma direcionalidade explicitamente tonal, são capazes de despertar articular um discurso coeso e bem estruturado. Um desses exemplos é a obra Variazione sulla Folia: Studi da Francisco Goya, escrita em 1989 pelo violonista e compositor italiano Angelo Gilardino (nascido em 1941). Esta obra variação não apresenta o tema de forma clara, desenvolvendo-se em caminhos beethovenianos de completo distanciamento do tema e de retornos inesperados, de forma caótica e insistente, na qual o autor aborda o tema Folias de Espanha na forma de uma alucinação musical ${ }^{51}$.

\footnotetext{
${ }^{51}$ ATTADEMO, 2001.
} 


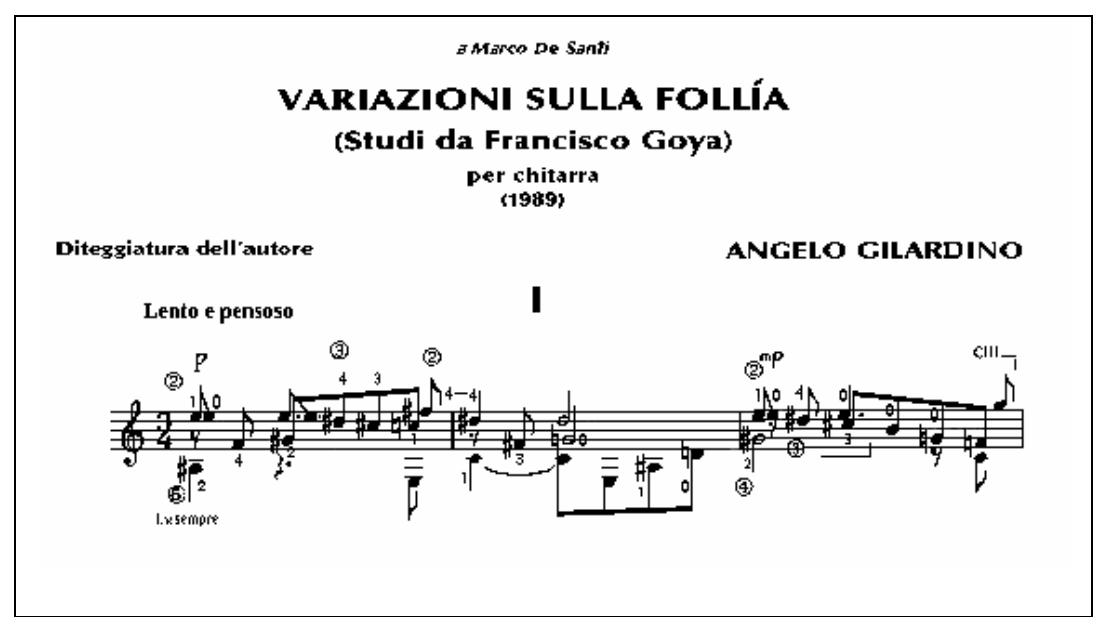

Fig.4.26: Gilardino: Variazione sulla Folia: Studi da Francisco Goya (1989), tema

Uma outra abordagem interessante foi realizada pelo compositor norte-americano Anthony Glise (nascido em 1956) em Theme and Variations on Folias de España, Op. 15 (1990). A obra se desenvolve a partir do tema ligeiramente alterado, através de cinco variações e uma reprise do tema inicial, que não ampliam apenas a idéia temática, mas também sua estrutura formal. Trata-se de uma verdadeira síntese de estilos, uma vez que o autor preserva o perfil renascentista do tema e as variações seguem o modelo de processo dinâmico de desenvolvimento evolutivo, porém com certos elementos harmônicos e rítmicos contemporâneos. Seu ambiente geral explora os timbres escuros do instrumento, em um tratamento mais polifônico: 


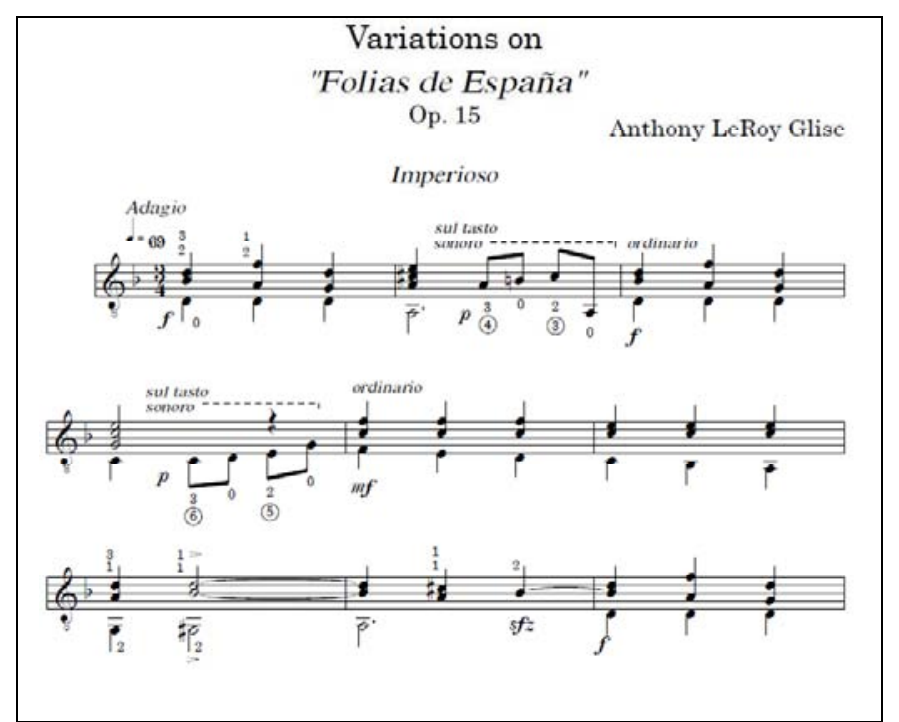

Fig.4.27: Glise: Theme and Variations on Folias de España, Op. 15 (1990), tema

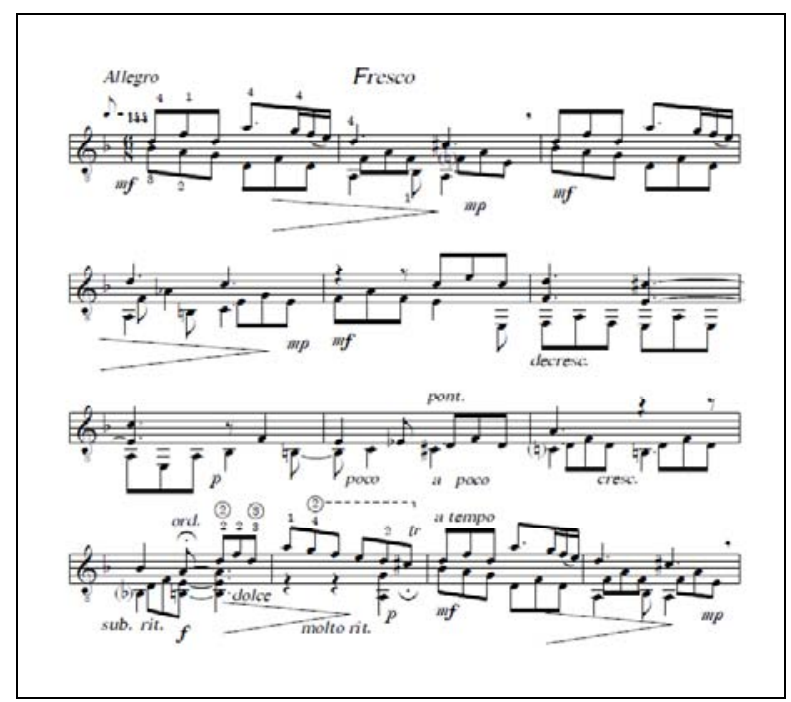

Fig.4.28: Glise: Theme and Variations on Folias de España, Op. 15 (1990), exemplo de polifonia

Mais interessante ainda é o texto que acompanha a partitura, na qual Glise expõe uma espécie de "diário de bordo" sobre a gênese da obra, numa abordagem teológica e filosófica. O compositor sustenta a tese de que "a Folia representa uma progressão harmônica quase-perfeita para escrever variações em um formato quase conservador porém virtuosístico" $^{\natural 2}$. Tomando um modelo teórico desenvolvido pelo escritor tcheco Milan

\footnotetext{
${ }^{52}$ GLISE, 1990, p.3.
} 
Kundera (nascido em 1929), Glise classifica dois tipos de processo composicional: um de expansão - no qual o compositor expande uma idéia temática e a transforma em algo novo - e outro de internalização - em que o compositor busca extrair os elementos temáticos mantendo o formato de um tema. Para ele, esses processos distintos estão relacionados com as culturas ocidental e oriental, sendo que o processo de escrever variações leva o compositor a examinar seu interior subjetivo ${ }^{53}$.

O compositor norte-americano lembra que as modernas religiões do Ocidente estabelecem um tipo de contato com a divindade por meio de uma relação "vertical", que parte do fiel em direção a Deus, o que também levou nossa cultura a um estado geral de individualidade. Por extensão, os processos composicionais tradicionalmente baseiam-se no conceito de expansão "para fora" - e "para cima" no que diz respeito à estrutura harmônica vertical - a partir do material temático. Do ponto de vista do Oriente, os fiéis possuem um acesso indireto e menos pessoal com Deus: a preocupação final é para com a “comunidade" quer se trate do país, região ou comunidade da aldeia. É uma preocupação que parte de um indivíduo para outro de forma linear, e somente então a Deus, numa busca pessoal interna. A conexão com a música estende-se às estruturas lineares e circulares da música modal ${ }^{54}$.

Partindo dessa concepção estético-filosófica, Glise considera que os compositores desenvolvem seu interior ao escrever variações sobre um tema, que representa uma aventura profunda e subjetiva na alma do compositor e até mesmo em sua memória genética/espiritual. Segundo Glise, trata-se de um meio de composição que exige autoconsciência, domínio do material temático e uma abordagem que requer uma

\footnotetext{
${ }^{53}$ GLISE, op.cit., p.4.

${ }^{54}$ Id., Ibid., pp.4-5.
} 
maturidade composicional que poucos compositores conseguiram atingir. E para ele, "a Folia, como tema, é um dos motivos mais acessíveis e flexíveis imagináveis para experimentar essa severa jornada para a alma",55.

${ }^{55}$ GLISE, op.cit., p.5. 


\subsection{Pastiches neobarrocos da Folias de Espanha}

O termo pastiche é etimologicamente derivado da palavra italiana pasticcio (massa ou amálgama) e era aplicado pejorativamente, no campo da pintura, a quadros forjados com tal perícia imitativa que costumavam ser confundidos com os originais. Deliberadamente cultivado por inúmeros autores, o pastiche faz uso de processos como a adaptação (modificação de material artístico de um gênero para outro distinto), a apropriação (empréstimo deliberado), a bricolagem (criação a partir de fontes e modelos heterogêneos), e a montagem. Antigamente, o pastiche aproximava-se da paródia e da sátira, realizando um misto de homenagem com sublimação de textos antecedentes, ressaltando, por um lado, a força e o prestígio da tradição, e gerando, por outro, a provocação pela subversão dos textos antecessores, como uma forma de desqualificar o sistema e o código vigentes. Este processo de escrita não significa degradação ou falta de criatividade, como sustentam certos críticos embasados nas premissas neo-românticas que valorizam a originalidade e desprezam as formas derivativas, rotulando-as de valor estético nulo ${ }^{56}$.

O pastiche ressurgiu durante o neoclassicismo com a colagem e reaproveitamento de moldes e estilemas, reabilitando-se e libertando-se do estigma de um estilo menor. Sua retomada na época pós-moderna está associada ao fenômeno do fim da originalidade e do estilo autoral, à procura de significado e identidade pela apropriação deliberada, e à percepção esquizofrênica do mundo e da cultura como um manancial de fragmentos permanentemente reutilizáveis. O modelo social incorporado pela arte pós-moderna é o americano, em que “[...] a nova cultura pós-moderna global [...] é expressão interna e

\footnotetext{
${ }^{56}$ CEIA \& AFONSO, 2009.
} 
superestrutural de uma nova era de dominação, militar e econômica, dos Estados Unidos sobre o resto do mundo [...., $]^{, 57}$.

A produção cultural passou a ficar atrelada à lógica do mercado, que busca desvairadamente produtos que ofereçam novidades, e à alta velocidade do turn-over, refletido na impossibilidade de se falar na consolidação de um estilo único, mas na pluralidade estilística. Assim, ao contrário do padrão modernista calcado nos estilos pessoais (Picasso, Stravinsky), a Pós-Modernidade não oferece espaço para a consagração de individualidades estilísticas. Essa impossibilidade converte-se em terreno fértil para a retomada da imitação e a busca do passado para suprir a ausência de sentido dos paradoxos da arte contemporânea.

Como vimos em capítulos anteriores ${ }^{58}$, a paródia foi utilizada como um poderoso instrumento narrativo e temporal. No século XX, este conceito perdeu sua função original de crítica social, uma vez que a paródia passou a ser considerada meramente como um desvio momentâneo de uma norma que acabava sendo reafirmada. Ela emergiu da mudança histórica ocorrida com o novo capitalismo: o mundo efêmero e descentralizado da tecnologia, do consumismo e da indústria cultural, no qual as indústrias de serviços, finanças e informação triunfam sobre a produção tradicional, e a política de classes cede terreno a uma série difusa de políticas de identidades ${ }^{59}$. Isso porque a ideologia dominante do capitalismo tardio passou a ser um instrumento menos eficaz de dominação social, uma vez que novos modelos de controle baseados na tecnocracia e no emergentismo garantem outras formas mais sofisticadas de controle da sociedade ${ }^{60}$.

\footnotetext{
${ }^{57}$ JAMESON, 2002, p.31.

${ }^{58}$ Cf. os capítulos 2.7 e 3.2 .

${ }^{59}$ EAGLETON, op.cit., p.189.

${ }^{60}$ Referimo-nos à recente mudança de controle social, antes baseada exclusivamente na esfera do discurso, para as novas estruturas cibernéticas auto-organizadas. O próprio conceito de cibernética foi projetado com o
} 
Jameson afirma que a paródia não encontra mais seu lugar na atual conjuntura cultural, sendo que o retorno às formas do passado encontra seu melhor veículo na expressão na fala anônima do pastiche:

Nessa situação, não há mais escopo para a paródia, ela teve seu momento, e agora essa estranha novidade, o pastiche, vem lentamente tomar seu lugar. $\mathrm{O}$ pastiche, como a paródia, é o imitar de um estilo único, peculiar ou idiossincrásico, é o colocar de uma máscara lingüística, é falar em uma linguagem morta. Mas é uma prática neutralizada de tal imitação, sem nenhum dos motivos inconfessos da paródia, sem o riso e sem a convicção de que, ao lado dessa linguagem anormal que se empresta por um momento, ainda existe uma saudável normalidade lingüística. Desse modo, o pastiche é uma paródia branca, uma estátua sem olhos: está para a paródia assim como uma certa ironia branca - outro fenômeno moderno interessante e historicamente original - está para o que Wayne Booth chama as "ironias estáveis' do século XVIII. (JAMESON, 2002, p.44-45).

Se durante o Modernismo a paródia era um recurso que evocava algum nível de crítica social, na Pós-Modernidade ela se tornou estéril, dando lugar a esse novo recurso, o pastiche, que recria e modifica - da mesma maneira profetizada por George Orwell em $1984^{61}$, um passado ausente, que se torna um simulacro platônico. Essa reinvenção do passado reflete a atual crise da historicidade, espelhada pela recente produção de obras elaboradas a partir de ideologemas recombinados - sempre com o prefixo "neo" (neobarroca, neoclássica, etc.) - e representações de estereótipos do passado. Retomando a reflexão de Jameson, verificamos que a:

[...] situação estética gerada pelo desaparecimento do referente histórico [... passa a] representar nossas idéias e estereótipos sobre o passado (que logo se transforma em 'história pop"). Desse modo, a produção cultural é relegada a um espaço mental que não é mais o do velho monádico, mas o de um 'espírito objetivo' coletivo e degradado: ela não pode mais contemplar um mundo real putativo, ou uma reconstrução de uma história passada que antes era um presente; em vez disso, como na caverna de Platão, tem que traçar nossas imagens mentais do passado nas paredes que as confinam. Se sobrou algum tipo de realismo aqui, é o 'realismo' derivado do choque da percepção desse confinamento e da consciência gradual de que estamos condenados a buscar a

objetivo de construção de um organismo central de controle de ações, ou seja, um sistema que informa diretamente os detentores do poder: o sistema do cartão de crédito, por exemplo, é uma dessas formas de monitoramento. Para maiores esclarecimentos sobre esta temática, cf. SAWYER, 2005.

${ }^{61}$ ORWELL, 1998. 
Historia através de nossas próprias imagens pop e dos simulacros daquela história que continua para sempre fora de nosso alcance. (JAMESON, 2002, p.52).

A partir do evidenciamento da Folias de Espanha no cinema, o tema encontrou um novo terreno para florescer na arte pós-moderna, readquirindo sua antiga popularidade na cultura, desta vez globalizada - ou seja, a partir do modelo de cultura e historicidade "pop" norte-americanos, conforme vimos em Jameson. Essa popularidade não é mais de uma classe aristocrática como no antigo regime, mas de uma categoria semi-especializada de compositores que busca no tema antigo uma fonte de inspiração para articulações em forma de clichês barrocos, uma vez que os modelos utilizados são quase sempre baseados em Corelli, Marais ou Haendel. Não por acaso, a lista de gravações disponíveis no mercado fonográfico mostra que as versões da Folias de Espanha dos três compositores ultrapassam mencionados todos os demais.

Em 1997, foi inaugurada a já mencionada homepage La Folia: a Musical Cathedral, dos colecionadores Paul Gabler e Werner Ircking. Não é preciso dizer que esta fonte de informações aberta também contribuiu para um incremento na circulação do tema entre compositores, intérpretes e ouvintes, em várias localidades do mundo. A página ainda se encontra disponível na rede e tem crescido e se consolidado como uma das mais respeitáveis fontes de informação e divulgação do tema. A autoria coletiva da Folias de Espanha, após a disponibilização na rede mundial, assumiu um caráter emergente e autogerativo $^{62}$.

A lista de compositores que escreveram pastiches neobarrocos a partir de então é imensa, e praticamente impossível de se analisar cada caso isoladamente - novamente,

\footnotetext{
${ }^{62}$ Para um aprofundamento no conceito de emergentismo, cf. JOHNSON, 2003.
} 
abre-se uma nova possibilidade temática para futuras pesquisas deste material. A simples audição dos exemplos em áudio, ou a leitura das características dessas obras quando não há gravações disponíveis, nos permitiu elaborar uma categoria exclusiva de pastiches que engloba aproximadamente $80 \%$ do que foi composto utilizando o tema Folias de Espanha, em um total de aproximadamente 180 obras $^{63}$. Um desses exemplos, que ilustra essa numerosa categoria, é o concerto Folias for Guitar and Orchestra (2002) de Roberto Sierra (nascido em 1953), que segundo o compositor, foi inspirado nas variações de Marais. A orquestração desse concerto é engenhosa e a parte solista para violão possui um tratamento virtuosístico.

Das composições restantes, aproximadamente 30 fogem do lugar comum, ou possuem uma estética mais vanguardista. Passaremos a uma breve descrição de algumas dessas obras, a fim de traçar um quadro geral das inovações que envolvem a Folias de Espanha como um ponto de partida temático para novos processos criativos.

- Riccardo Malipiero (1914): Aria variata sulla Folia (1979), para violão solo. Esta obra não possui fórmula de compasso e possui uma escrita dentro da linguagem moderna, a fim de propiciar uma execução com a liberdade de uma fantasia.

- Jacques Berthier (1923-1994): Laudate Domino (1980). Aparentemente a única obra do fim do século XX que empregou o tema Folias de Espanha na música litúrgica.

- Andrew Stiller (1946): Spanish Folias (1984), para quarteto de violões. Esta composição se destaca por empregar quartos de tom graças às diferentes afinações empregadas no quarteto.

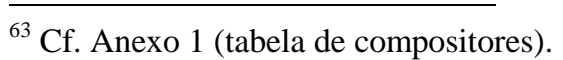


- Richard Bellak (1945): Prelude 'Folia' and Fugue N.6 (1992), para piano. Esta obra utiliza a Folias de Espanha combinando a forma antiga do prelúdio e fuga com a linguagem do jazz.

- Ian Krouse (1956-): Folias (1992), para quarteto de violões. Esta peça transita por diversos estilos musicais, como o Barroco, o Renascentista e o da música contemporânea.

- David Denniston (1957): La Folia Mutations (1996), para sons sintetizados e sampleados em tape. Uma das únicas versões eletroacústicas conhecidas que utilizam o tema, reelaborando-a a partir das novas tecnologias de áudio do século $\mathrm{XX}$.

- Paul Reale (1943): Il Trinfo della Folia (Piano Sonate No8) (1997) para piano solo. O tema foi utilizado em uma sonata de movimento único, dentro da linguagem contemporânea. O tema Folias de Espanha é abordado indiretamente, somente aparecendo integralmente, "triunfante", na conclusão da sonata.

- André Klenes (1954): Folia (1998), para quinteto de cordas e contrabaixo. O respeitado baixista utiliza a linguagem do jazz, mesclada aos ritmos da salsa e habanera, a fim de reforçar o aspecto popular da origem do tema Folias.

- Harry Payuta (1952-): La Folia (2000), para cítara e harpa barroca. O emprego da cítara na obra deste compositor de El Salvador a torna muito rica em termos timbrísticos, além dos ornamentos realizados por Payuta, que acrescentam um toque oriental ao tema Folias. 
- Nobuo Uematsu (1959-): Final Fantsy IX (2000), trilha sonora para game. Possivelmente a primeira versão escrita utilizando o tema Folias de Espanha como trilha sonora para um jogo eletrônico.

- Arnd Sprung (1954-): Reflexiones sobre La Folia (2002), para violão. A introdução com trêmulo e as improvisações utilizando a linguagem do jazz criam uma sonoridade única para esta versão da Folia.

- Tómas Marco (1942-): Vanitas con chaconas y folias (2006), para flauta e orquestra. Esta obra não apresenta uma sequiência lógica e conta com sobreposições de idéias musicais contrastantes; a flauta trava um interessante diálogo com a orquestra. 


\section{CONSIDERAÇÕES FINAIS}

O presente estudo teve como questão essencial descobrir a razão pela qual o tema Folias de Espanha conquistou um lugar permanente ao longo da História da Música. A resposta para a pergunta revelou-se múltipla durante do processo de pesquisa, sendo que a mesma não pôde ser esclarecida por uma resposta simples, mas como uma série de eventos que favoreceu sua posição de destaque nos repertórios de diferentes períodos históricos, estilos e nacionalidades.

Em primeiro lugar, é necessário admitir que a permanência do tema é mais um fenômeno de aparência do que propriamente de perenidade: seu ciclo histórico - strictu sensu - é bem delineado, começando de fato na Península Ibérica em meados do século XVII e terminando em toda a Europa no final do XVIII ${ }^{64}$. Os antecedentes levantados poderiam muito bem ter sido desenvolvidos em outros temas diferentes (e muitos deles de fato o foram); do mesmo modo que o século XIX apenas resgatou o tema como um olhar renovado do passado e a Pós-Modernidade fez dele um pastiche ${ }^{65}$. Mesmo a sua popularidade no repertório guitarrístico do século XIX é um fato esteticamente anacrônico, como toda a produção dos compositores da chamada Época de Ouro do violão ${ }^{66}$.

Em segundo lugar, houve uma confluência de diversos fatores que tornaram o tema Folias um epígono da música instrumental renascentista, sendo que o principal é que este reuniu diversos grounds, como a romanesca, a pavaniglia, etc., inicialmente como linha de baixo e depois como seqüência de acordes ${ }^{67}$. A flexibilidade do tema em incorporar-se e adaptar-se a novos estilos musicais não foi apenas surpreendente, mas também

\footnotetext{
${ }^{64}$ Cf. capítulos 1.1 e 1.2 .

${ }^{65}$ Cf. capítulos 3.4 e 4.4 .

${ }^{66}$ Cf. capítulo 3.3.

${ }^{67}$ Cf. capítulos 1.3 e 1.4 .
} 
característica de sua sobrevivência. Outra particularidade notável refere-se à grande variedade de instrumentos empregados, com uma forte incidência de obras escritas para violão, em que o mesmo tema soa de maneira espontânea e idiomática.

Outro importante fator que contribuiu para a forte popularidade na música instrumental renascentista e barroca foi que tanto a linha de baixo quanto o modelo harmônico posterior eram de fácil assimilação para a prática da diminuição e improvisações, constituindo-se num dos mais importantes modelos didáticos por um longo período de tempo. Uma das possíveis razões pela qual o tema Folias de Espanha foi constantemente retomado na História da Música reside justamente em sua simplicidade harmônica, melódica e rítmica, que oferece um campo de possibilidades extremamente aberto para novas invenções, além do fato de que todo o tipo de técnica de variação se ajustava perfeitamente ao caráter hipnótico que o tema carrega, ao mesmo tempo possuindo uma extraordinária maleabilidade em se transmutar em um caráter distinto de seu ethos original. Assim, a consolidação do tema Folias de Espanha no final do século XVII, no formato que chegou até os dias atuais, representou uma feliz coincidência em termos de elaboração coletiva de uma idéia musical que ascendeu da tradição popular à elite, e abriu caminhos para novas estéticas que surgiriam no curso da História da Música.

Sua trajetória histórica percorreu o seguinte caminho: a) ground, b) esquema harmônico, c) sarabanda, d) paródia, e) pastiche. A transformação do esquema harmônico Folias no tema Folias de Espanha foi o resultado de um processo de transformação coletiva, e não por implantação individual, embora alguns autores insistam em atribuir-lhe uma "autoria": alguns a Lully, outros a Farinelli ou até mesmo a Corelli ${ }^{68}$. O motivo de tais atribuições pode ser deduzido a partir da observação da tabela abaixo, que demonstra que a

\footnotetext{
${ }^{68}$ Cf. capítulos 1.7 e 2.5 .
} 
árvore genealógica da Folias de Espanha possui duas correntes principais: uma "lullyana", de característica mais ligada à música vocal e de dança estilizada, e outra "corelliana", cujas obras possuem uma faceta mais instrumental, utilizadas mais recorrentemente em esquemas de variações e/ou improvisações. A mesma tabela revela ainda o importante papel de alguns renovadores da tradição como Haendel (1727), Cherubini (1798), Brahms (1860), Ponce (1929) e Kubrick 1975.

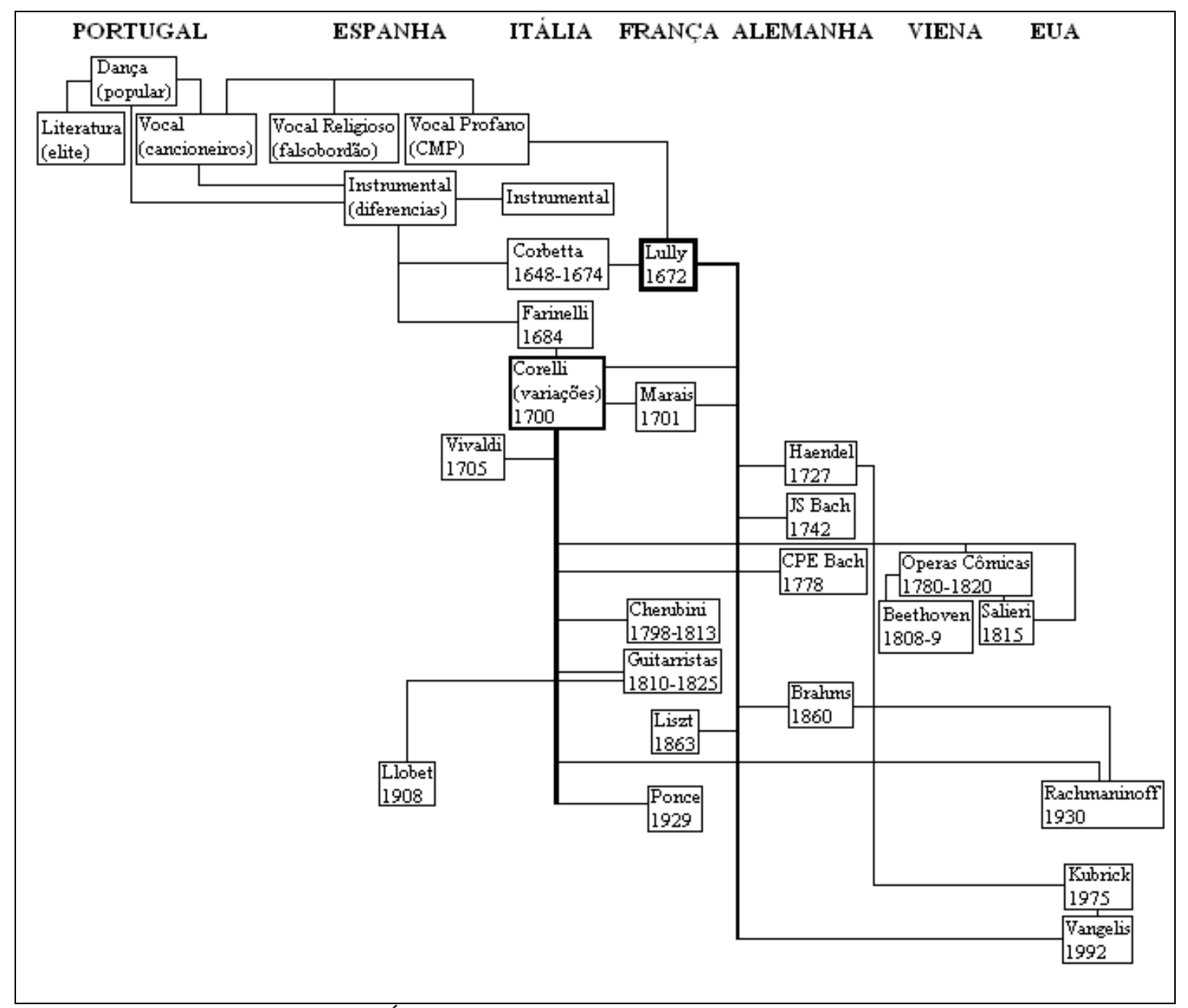

Árvore genealógica da Folias de Espanha 
Outro aspecto, mais psicológico que histórico, refere-se ao fascínio que o tema desperta devido à sua harmonização em forma de palíndromo, que associado ao passo regular e repetitivo da sarabanda gera um efeito quase hipnótico, além de uma sensação estésica de suspensão temporal. Este atributo foi amplamente explorado por compositores e cineastas para gerar interessantes relações de significado ${ }^{69}$.

Em sua primeira fase, como linha de baixo e esquema harmônico (Folias), existia uma forte relação com a escola italiana barroca e com a popularidade da guitarra romântica, sem os quais dificilmente o tema teria tido tamanha repercussão histórica e transnacional ${ }^{70}$. O mesmo fenômeno se repetiu com os compositores da guitarra romântica da escola italiana e espanhola em inícios do século XIX.

Um importante fator que contribuiu para colocar o tema em evidência em determinados momentos, e fazê-lo perder sua importância em outros, foi o desenvolvimento das formas musicais, sobretudo a forma Tema e Variações. A própria trajetória desta forma determinou paralelamente o nascimento, ápice e declínio da Folias de Espanha em função do perfeito ajuste entre conteúdo e forma. Foi também o aspecto formal que garantiu a permanência histórica de uma época determinada e também de sua retomada em outros períodos e estilos posteriores. Esse aspecto pode ser enquadrado em um eixo temporal, sendo que existe um outro eixo, atemporal, que é seu uso como elemento de paródia ou pastiche, que transforma o tema num elemento que remete a um ambiente arcaico e solene ao mesmo tempo. Foi justamente esse elemento que conectou autores tão distantes historicamente como Bach, Beethoven, Brahms e Kubrick, cujas obras analisadas

\footnotetext{
${ }^{69}$ Cf. capítulos $2.7,3.2$ e 4.3 .

${ }^{70} \mathrm{Cf}$. capítulos 1.5 e 1.6 .
} 
nesta tese estão costuradas pelo eixo comum da Folias de Espanha enquanto elemento remissivo e histórico ${ }^{71}$.

Um ponto relevante que nos foi possível verificar, ao longo do estudo, refere-se ao fato de que a melodia Folias apresentava uma grande variedade de formas melódicas harmônicas e rítmicas, uma vez que a linha de baixo era quase idêntica a diversos gêneros, como se ela estivesse em busca, de forma autônoma, de um formato temático bem delineado que seria encontrado em sua forma definitiva no tema Folias de Espanha. O estudo do repertório demonstrou que as obras mais antigas, enquanto o tema estava em formação potencial, eram muito mais diversificadas e criativas; ao passo que ao se cristalizar em uma forma definida, como ato consumado, o tema começou a sofrer de uma certa repetitividade, gerando o desgaste típico de obras que se tornam referências permanentes. Devemos destacar que neste momento a Folias de Espanha passou a representar o próprio paradoxo entre essência e aparência da forma Tema e Variações: no sentido de que qualquer variação pode ser o tema, ou o inverso, o tema pode ser considerado, na maior parte das ocorrências, uma versão "despida" de suas variações. Se tal paradoxo, por um lado, fortaleceu a forma em uma determinada época, por outro lado foi justamente o motivo que determinou sua desintegração na segunda metade do século $\mathrm{XVIII}^{72}$.

Podemos ainda sublinhar uma importante conexão sociológica ao relacionar a Folias de Espanha com a retórica clássica e a política do antigo regime. Um dos aspectos sustentou sua longevidade foi justamente responder de forma muito clara às preceptivas retóricas que formaram a base para a construção da idéia de discurso musical na música dos

\footnotetext{
${ }^{71}$ Cf. capítulos 2.7, 3.2, 3.4 e 4.3.

${ }^{72} \mathrm{Cf}$. capítulos 2.8 e 3.1 .
} 
séculos XVII e XVIII. Essa estreita relação da Folias de Espanha com os códigos retóricos teve uma natural extensão no que se referia ao aspecto do uso ideológico e propagandístico francês durante o reinado de Luis $\mathrm{XIV}^{73}$. Tais conexões coincidiram, inclusive, com o primeiro auge que o tema adquiriu em sua história.

Finalmente, vimos que o fenômeno de ressurgimento no século XX, após um período de ostracismo - pelo menos em relação à produção erudita, uma vez que a popular se manteve em diversas localidades, especialmente na Escandinávia ${ }^{74}$ - foi na verdade impulsionado pelo mesmo motivo que levou Bach, Beethoven e Kubrick a utilizarem a Folias de Espanha: como um elemento arcaico e representativo de um passado revisitado ${ }^{75}$. Não se trata mais de uma forma musical conectada ao seu tempo, mas de uma entidade carregada de um sentido histórico latente, cujo significado dependerá exclusivamente da maneira de uso que o compositor contemporâneo irá empregar - o tema em si já não possui mais o mesmo poder de comunicação que tinha nos séculos XVII e XVIII.

O conceito agostiniano/wagneriano de que só pode ser eterno aquilo que está fora do tempo serve apenas para confirmar que a Folias de Espanha transcendeu sua própria temporalidade.

\footnotetext{
${ }^{73}$ Cf. capítulos 2.1 à 2.6 .

${ }^{74}$ Cf. capítulo 3.4 .

${ }^{75}$ Cf. capítulos 4.1 e 4.2 .
} 


\section{REFERÊNCIAS BIBLIOGRÁFICAS}

\section{LIVROS}

AGOSTINHO, Santo. Confissões. Tradução de J.Oliveira Santos e A. Ambrósio de Pina. São Paulo: Nova Cultural, 1999.

ALCÁZAR, Miguel. Obra completa para guitarra de Manuel M. Ponce. Cidade de México: Ediciones Étoile, 2000.

1989. (editor). The Segovia-Ponce Letters. Columbus: Editions Orphee,

ANNALA, Hannu; MÄTLIK, Heiki. Handbook of Guitar and Lute Composers. Translated by Katarina Backman. Pacific: Mel Bay, 2008.

ARNOLD, Ben. The Liszt companion. Santa Barbara: Greenwood Publishing Group, 2002.

BAKHTIN, Mikhail. A cultura popular na Idade Média e no Renascimento: o contexto de François Rabelais. Tradução de Yara Frateschi. São Paulo: Hucitec, 1999.

BARTEL, Dietrich. Musica Poetica: Musical Rhetorical Figures in German Baroque Music. Nebraska: University of Nebraska Press, 1998.

BAUMGARTEN, A. Meditationes philosophicae de nonnullis ad poema pertinentibus (1735). London: The Ray Society, 1957.

BOULTON, Marjorie. The Anatomy of Prose. Florence: Routledge, 1980.

BOYD, Malcolm (org.). Music and the French Revolution. Cambridge: Cambridge University Press, 1992.

BROYLES, Michael. Beethoven: the emergence and evolution of Beethoven's heroic style. Florence: Routledge, 1987.

BURKE, Peter. Cultura Popular na Idade Moderna. Tradução de Denise Bottmann. São Paulo: Companhia das Letras, 1989.

BURNHAM, Scott G.; STEINBERG, Michael P. Beethoven and his world. Princeton: Princeton University Press, 2000.

BUTT, John. Bach: Mass in B Minor. Cambridge University Press, 1991.

CARRASCO, Ney. Sygkhronos: a formação da poética musical do cinema. São Paulo: Via Lettera, 2003.

CÍCERO, Marco Túlio. El Orador. Madrid: Alianza, 1991. 
DESCARTES, R. As paixões da alma. São Paulo: Ed. Nova Cultural, 1999.

DUBOIS, J. Retórica Geral. Tradução de Carlos Filipe Moisés. São Paulo: Cultrix, 1974.

DUDEQUE, Norton. História do Violão. Curitiba: Editora da UFPR, 1994.

EAGLETON, Terry. As ilusões do pós-modernismo. Rio de Janeiro: Jorge Zahar, 1998.

ERASMO, Desidério. Elogio da Loucura. Tradução de Paulo Neves. Porto Alegre: L\&PM, 2003.

. On Copia of Words and Ideas: De Utraque Verborem Ac Rerum

Copia. Translated by Donald B. King \& H. David Rix. Wisconsin: Marquette University Press, 1999.

ESSES, Maurice. Dance and instrumental diferencias in Spain during the 17th and 18th centuries. New York: Pendragon Press, 1992.

GADAMER, Hans-Georg. Verdade e método: traços fundamentais de uma hermenêutica filosófica. Tradução de Flávio Paulo Meurer. Petrópolis: Editora Vozes, 1997.

GECK, Martin. Bach: Life and Work. Translated by John Hargraves. Boston: Houghton Mifflin Harcourt, 2006.

GINZBURG, Carlo. O queijo e os vermes: o cotidiano e as idéias de um moleiro perseguido pela Inquisição. Traduzido por Maria Betânia Amoroso e José Paulo Paes. São Paulo: Companhia das Letras, 2007.

GROUT, Donald J.; PALISCA, Claude V. História da Música Ocidental. Tradução de Ana Luísa Faria. Lisboa: Gradiva, 1997.

GÜLKE, Peter. Zur Neuausgabe der Sinfonie Nr.5 von Ludwig van Beethoven: Werke und Edition. New York: Peters, 1978.

HARNONCOURT, N. O Diálogo Musical: Monteverdi, Bach e Mozart. Tradução de Luiz Paulo Sampaio. Rio de Janeiro: Jorge Zahar, 1993.

HECK, Thomas F. Mauro Giuliani: virtuoso guitarist and composer. Columbus: Editions Orphée, 1995.

HOPPIN, Richard H. Medieval Music. New York: W.W. Norton \& Co., 1978.

HOUAISS, Antonio (org): Dicionário Houaiss da Língua Portuguesa. São Paulo: Objetiva 2001. 
HUDSON, Richard. The Folia, the saraband, the passacaglia, and the chaconne: the historical evolution of four forms that originated in music for the five-course Spanish guitar. Stuttgart: Hanssler-Verlag, 1982.

HUTCHEON, Linda. A Theory of Parody: The Teachings of Twentieth-century Art Forms. Illinois: University of Illinois Press, 1991.

. Poética do Pós-modernismo: História, Teoria, Ficção. Tradução de

Ricardo Cruz. Rio de Janeiro: Imago, 1991.

JAMESON, Frederic. Pós-modernismo: a Lógica Cultural do Capitalismo Tardio.

Tradução de Marial Elisa Cevasco. São Paulo: Ática, 2002.

JOHNSON, Steven. Emergência: a vida integrada de formigas, cérebros, cidades e softwares. Tradução de Maria Carmelita Pádua Dias. Rio de Janeiro: Jorge Zahar, 2003.

KERMAN, Joseph. Musicologia. Tradução de Álvaro Cabral. São Paulo: Martins Fontes, 1987.

KINDERMAN, William. Beethoven's Compositional Process. Nebraska: University of Nebraska Press, 1991.

LITTLEWOOD, Julian. The variations of Johannes Brahms. London: Plumbago Books and Arts, 2004.

McVEIGH, Simon; HIRSHBERG, Jehoash. The Italian solo concerto, 1700-1760: rhetorical strategies and style history. Suffolk: Boydell Press, 2004.

MERWE, Peter Van der. Roots of the classical: the popular origins of western music. Oxford: Oxford University Press, 2004.

MUSGRAVE, Michael. The music of Brahms. Oxford: Oxford University Press, 1994.

NATTIEZ, Jean-Jacques. O Combate entre Cronos e Orfeu: Ensaios de Semiologia Musical Aplicada. Tradução de Luiz Paulo Sampaio. São Paulo: Via Lettera, 2005.

NETTL, Paul. The Beethoven Encyclopedia: His Life and Art from A to Z. Bridgewater: Replica Books, 1999.

ORWELL, George. 1984. São Paulo: Companhia Editora Nacional, 1998.

PELLEGRIN, Harry. Classic Guitar Method. New York: PAB, 2006. p.178.

ROSE, Margaret A. Parody/Meta-Fiction: An Analysis of Parody as a Critical Mirror to the Writing and Reception of Fiction. London: Croom Helm, 1979. 
Parody: ancient, modern, and post-modern. Cambridge University

Press, 1993.

ROSEN, Charles. Sonata Forms. New York: W. W. Norton, 1980.

SANTAELLA, Lúcia. Matrizes da linguagem e pensamento. São Paulo: Illuminuras, 2002.

SCHAMA, Simon. Citizens. New York: Alfred Knopf, 1989.

SCHMITZ, Arnold. Das romantische Beethovenbild: Darstellung und Kritik. Berlin: F. Dümmler, 1927.

SCHOENBERG, A. Princípios da composição musical. Tradução de Eduardo Seincman. São Paulo: Edusp, 1993.

SCHORSKE, Carl. Viena sin-de-siècle: política e cultura. Tradução de Denise Bottman. São Paulo: Companhia das Letras, 1988.

SCHWEITZER, Albert. J. S. Bach. Read Books, 2008.

SEINCMAN, Eduardo. Do tempo musical. São Paulo: Via Lettera, 2001.

Estética da comunicação musical. São Paulo: Via Lettera, 2008.

STEBLIN, Rita. A history of key characteristics in the eighteenth and early nineteenth centuries. Rochester: University of Rochester Press, 1996.

STOWELL, Robin. The Cambridge companion to the violin. Cambridge: Cambridge University Press, 1992.

THACKERAY, William Makepeace. The Memoirs of Barry Lyndon Esquire Written by Himself and Catherine a Story. Whitefish: Kessinger Publishing, 2004.

TOMÁS, Lia. Música e Filosofia: Estética Musical. São Paulo: Ed. Vitale, 2005.

TRINGALI, Dante. Introdução à Retórica: A Retórica como Crítica Literária. São Paulo: Duas Cidades, 1988.

WESTRUP, Jack Allan. Bach Cantatas. Seattle: University of Washington Press, 1969. 


\section{FAC-SÍMILES}

CARRÉ, Antoine. Livre de guitarre contenant plusieurs pièces... avec la manière de toucher sur la partie ou basse continue. Minkoff-edition, Fac-símile da edição de Paris, 1671. Genebra: 1977.

CORBETTA, Francesco. La Guitare Royale Dedieé au Roy de la Grande Bretagne. Paris: 1670; Facsimile ed. Minkoff, Paris: 1993.

OROZCO, Sebastian de Covarrubias. Tesoro de la Lengva Castellana, O Española. Madrid: por Luis Sanchez, impressor del Rey N.S. 1611.

MATTHESON, Johann. Der Vollkommene Capellmeister (Hamburg, 1739). Kassel: Bärenreiter, 1954.

ORTIZ, Diego. Tratado de glosas sobre clausulas y otros géneros de puntos en la musica de violones, Roma 1553.

REMÉDIOS, Joaquim Mendes dos (ed.). Obras de Gil Vicente. Fac-símile da edição de 1912.

ROA, Francisco; GÉRTRUDIX, Felipe. Libro de música de vihuela de Diego Pisador. Madrid: Editorial Pymalión, 2002. Edição facsimile da edição de Salamanca, 1552.

SALINAS, Francisco de. De musica libri septem. Salamanca, 1577. Edição fac-símile por Macario Santiago Kastner, Kassel-Basel: Barenreiter Verlag, 1958.

VICENTE, Gil. José Victorino Barreto Feio, J. C. Monteiro, J. G. Monteiro. Obras de Gil Vicente. Fac-símile da Edição de Langhoff: Paris, 1834. 
TESES E DISSERTAÇÕES

ANDERSON, Norman Douglas. Aspects of Early Major-Minor Tonality: Structural Characteristics of the Music of the Sixteenth and Seventeenth Centuries. Dissertação apresentada à Ohio State University, 1992.

ASSUMPÇÃO, Sérgio Eduardo. Ascendência Retórica das Formas Musicais. Dissertação de mestrado apresentada à Universidade de São Paulo, São Paulo, 2007.

CAMARGO, Guilherme de. A guitarra do século XIX em seus aspectos técnicos e estilístico-históricos a partir da tradução comentada e análise do "Método para guitarra" de Fernando Sor. Dissertação de mestrado apresentada à Universidade de São Paulo, São Paulo, 2005.

FIORENTINO, Giuseppe. Música Española del Renascimiento entre Tradición Oral y Transmisión Escrita: el Esquema de Folía en Processos de Composición e Improvisación. Tese de Doutorado apresentada a Universidad de Granada. Granada, 2009.

RAYNAL, Catherine. De la folia a la folie d'Espagne. Dissertação apresentada à Universidade de Paris IV [Paris-Sorbonne], 1993. 


\section{ARTIGOS E CAPÍTULOS DE LIVROS}

CROSS, Eric. Corelli and his legacy. In: Early Music, Vol. XXXIV, No. 3. Oxford University Press, 2006.

DEANE, Basil apud DEAN, Winton. Cherubini. In: The Musical Times, Vol. 107, No. 1484 (Oct., 1966), Published by: Musical Times Publications Ltd. pp. 871-872.

DEMPSEY, Michael. Barry Lyndon by Stanley Kubrick. In: Film Quarterly, Vol.30, No.1. California: University of California Press, 1976. pp.49-54.

JOACHIM, Henry. Three Milestones in the History of Violin Playing. I. Corelli. In: The Musical Times, Vol. 73, No. 1076 (Oct. 1, 1932), pp. 888-890.

HOYT, Reed J., Letter to the Editor. In: College Music Symposium 21, 1 (Spring 1982), p. 196-198.

HUDSON, Richard. The Folia, Fedele, and Falsobordone. In: The Musical Quarterly, Vol. 58, No. 3 (Jul., 1972), pp. 398-411.

. The Folia Melodies. In: Acta Musicologica, Vl.45, Fasc. 1 (Jan. -

Jun.,1973), pp.98-119. Basel: International Musicological Society, 1973.

Folia. In: SADIE, Stanley (ed.). The new Grove dictionary of music \& musicians. London: Macmillan, 1980. p.690-693.

KIRTON, Sarah. La Folia: The Greatest Hit of All Time. In: Northern California Spelmanslag News, Volume 15 Number 1, 2005. pp.4-8.

MENGOZZI, Stefano. The Folia As Subtext: Temporal and Narrative Contrasts in the Andante con moto of Beethoven's Fifth Symphony. Michigan: inédito, 2003. 48 páginas.

MICHELI, Lorenzo. Mauro Giuliani's Guitar Technique \& Early Nineteenth-Century Pedagogy. In: Guitar Forum 2. Winter. Londres: EGTA UK, 2003. pp.45-70.

NELSON, Thomas Allen. Barry Lyndon: Kubrick's Cinema of Disparity. In: Rocky Mountain Review of Language and Literature, Vol. 33, No. 1. Snowbird: Rocky Mountain Modern Language Association, 1979, pp. 39-51.

NIECKS, Frederick. Les Folies d'Espagne: a Study. In: The Musical Times 29, 1888. p. 717-721.

RAE, Caroline. Maurice Ohana: iconoclast or individualist? In: The Musical Times, Vol.132, N.1776 (February, 1991), pp.69-74.

RICE, John A. "La Folia" in Late Eighteenth- and Early Nineteenth-Century Vienna. In: Festschrift Otto Biba zum 60. Geburtstag, ed. Ingrid Fuchs, Tutzing, 2006. pp.85-96. 
SCHNEIDER, H. Der Formen- und Funktionswandel in den Chansons und Hymnen der Französischen Revolution. In: KOSELLECK, R.; REICHARDT, R. Die Französische Revolution als Bruch der gesellschaftlichen Bewusstseins. Munchen: Oldenburg Verlag, 1988. pp.421-478.

SISMAN, Elaine R. Brahms and the Variation Canon. In: 19th-Century Music, Vol. 14, No. 2 (Autumn, 1990), University of California Press, 1990. pp. 132-153.

STEVENSON, Robert. Liszt at Madrid and Lisbon: 1844-45. In: The Musical Quarterly, Vol. 65, No. 4 (Oct., 1979), pp. 493-512.

SUÁRES-PAJARES, Javier. Los virtuosismos de la guitarra española: del alhambrismo de Tárrega al neocasticismo de Rodrigo. In: JAMBOU, Louis. La musique entre France et Espagne: Interactions stylistiques. Paris: Presses Paris Sorbonne, 2004, pp. 231-252.

TESAURO, Emanuele. Argúcias humanas (1654). Trad. Gabriella Cipollini e João Adolfo. Hansen. In: Revista do IFAC, Ouro Preto, IFAC-UFOP, dez. 1997, n. 4.

YATES, Richard. G.F. Handel, Sarabande con variazioni, transcribed for guitar. Soundboard - The Journal of the Guitar Foundation of America, Vol. XXX, No. 2, p. 5053, published in October 2004. 


\section{PARTITURAS}

BACH, Johann Sebastian. Cantate "Mer hahn em neue Oberkeet", 1742. B.W. XXIX s/data. 1 partitura. Solistas e orquestra.

BEETHOVEN, Ludwig van. Sonaten: Band II. Edição de Louis Köhler e Rich. Schmidt. Edition Peters. Leipzig: 1943. 1 partitura. Piano.

Kalmus, s/data. 1 partitura. Orquestra.

Symphomy N.5 in C minor Op.76. New York: Edwin F.

BRAHMS, Johannes. Sextett für 2 Violinen, 2 Violen und 2 Violoncelli, Op.18. Bonn: N. Simrock, 1860. 1 partitura. Sexteto de cordas.

CORBETTA, Francesco. Folia (1671b). In: HUDSON, Richard. The Folia, the saraband, the passacaglia, and the chaconne : the historical evolution of four forms that originated in music for the five-course Spanish guitar. Stuttgart: Hanssler-Verlag, 1982. Guitarra barroca.

Folia (1674). In: HUDSON, Richard. The Folia, the saraband, the passacaglia, and the chaconne : the historical evolution of four forms that originated in music for the five-course Spanish guitar. Stuttgart: Hanssler-Verlag, 1982. Guitarra barroca.

CORELLI, Arcangelo. XII. Follia. Revisão de Pierre Gouin. Paris: Les Éditions Outremontaises, 2006. 1 partitura. Violino.

FOSSA, François. 5eme Fantasie sur l'air des Folies d'espagne Op.12. Bonn: N. Simrock, 1825. 1 partitura. Guitarra romântica.

GIULIANI, Mauro. VI Variations pour la Guitarre Sur lês Folies d'Espagne Oeuvre 45. Bonn: N. Simrock, 1814. 1 partitura. Guitarra romântica.

GLISE, Anthony LeRoy. Variations on "Folias de España" Op.15. Edição do autor, 2000. 1 partitura. Violão.

HAENDEL, Georg Friedrich. Sarabande de la Suíte XI, HWV 437. Revisão de Pierre Gouin. Paris: Les Éditions Outremontaises, 2005. 1 partitura. Cravo.

LISZT, Franz. Rhapsodie Espagnole. München: G. Henle Verlag, s/data. 1 partitura. Piano.

LLOBET, Miguel. Variaciones sobre un Tema de Sor Op.15 (1908). In: Guitar Works, vol. 1, 11 Original Compositions. Edited by Ronald Purcell. Heidelberg: Chanterelle Verlag, 1989. 1 partitura. Violão.

LULLY, Jean Baptiste. Air de Hautbois Folies d'Espagne (1672). In: HUDSON, Richard. The Folia, the saraband, the passacaglia, and the chaconne: the historical evolution of four 
forms that originated in music for the five-course Spanish guitar. Stuttgart: HansslerVerlag, 1982. 1 partitura. Quarteto de sopros.

MUDARRA, Alonso. Pavana I (Três librtos de música em cifra para vihuela, 1546). In: FIORENTINO, Giuseppe. Música Española del Renascimiento entre Tradición Oral y Transmisión Escrita: el Esquema de Folía en Processos de Composición e Improvisación. Tese de Doutorado apresentada a Universidad de Granada. Granada, 2009. Vihuela.

Pavana III para guitarra al temple nuevo (Três librtos de música em cifra para vihuela, 1546). In: FIORENTINO, Giuseppe. Música Española del Renascimiento entre Tradición Oral y Transmisión Escrita: el Esquema de Folía en Processos de Composición e Improvisación. Tese de Doutorado apresentada a Universidad de Granada. Granada, 2009. Vihuela.

OHANA Tiento pour guitare. Revisão e dedilhado de Narciso Yepes. Paris: M.R. Braun, 1968. 1 partitura. Violão.

PONCE, Manuel Maria. Variations sur "Folia de España” y Fuga (1929). ALCÁZAR, Miguel. Obra completa para guitarra de Manuel M. Ponce. Cidade de México: Ediciones Étoile, 2000. 1 partitura. Violão.

RACHMANINOFF, Sergei. Variations on a Theme of Corelli, Op.42 (1931). New York: Dover, s/data. 1 partitura. Piano.

SANZ, Gaspar. Folias (1674). . In: HUDSON, Richard. The Folia, the saraband, the passacaglia, and the chaconne : the historical evolution of four forms that originated in music for the five-course Spanish guitar. Stuttgart: Hanssler-Verlag, 1982. Guitarra barroca.

SOR, Fernando. Les Folis d'Espagne, Variées, et un menuet Euvre 15. Paris: Magasin de Musique de Metssonier, 1815. 1 partitura. Guitarra romântica.

VIVALDI, Antonio. Sonata Op.1 N.12 La Follia (1705). Werner Icking, s/data. 1 partitura. Orquestra de cordas. 


\section{ENCARTES DE GRAVAÇÕES EM COMPACT DISCS E LONG PLAYS}

ATTADEMO, Luigi. Folias: Sanz, Giuliani, Ponce, Gilardino, Sor, Ohana. Magazine 'Guitart' compact disc GUIT 2026. 2001.

DUARTE, John W. Andres Segovia: Recordings 1927-1939. London: EMI, 1980.

GOY, François-Pierre. Marin Marais: Les Folies d'Espagne, Suite en mi, Le Labyrinthe. Ensemble Spirale, Marianne Muller viola da gamba and conductor. France: Zig-Zag Territoires, 2006.

HINSON, Maurice. Klavier Variations on La Folia (James Bonn). Pan Records, 1982.

HOWARD, Leslie. Liszt: the complete music for solo piano. Hyperion compact disc CDA 67145, 1997.

HOPPSTOCK, Tilman. Manuel M. Ponce: Variations and Sonatas. Signum compact disc SIC X114-00, 2000.

KELLER, Ginette. Brahms: Sextuor a Cordes N.1. Les Musiciens. Harmonia Mundi compact disc HMC 901073 (ADD), 1982.

KOREVAAR, David. Brahms Variations for Piano. Ivory Classics CD-74004, 2004.

LINDBERG, Jacob. Folias, Follie \& Folie, BIS compact disc, 1997.

NERY, Rui Vieira. Altre Follie. Cd Hespérion XXI, 2005.

. La Folia (1490-1701). Cd AliaVox, 1998

NOKLEBERG, Einar Steen. Grieg, Complete piano music Volume 5. CD Naxos, 1995.

RADO, Giancarlo. Folia from La guitarre royalle, Paris 1671. Erato Disques, Paris, 2001.

WADE, Graham. Maurice Ohana (1913-1992) Tiento - Si le jour paraît... - Cadran lunaire.

In: Ohana: Music for Ten-String Guitar Graham Anthony Devine. CD Naxos, 2009.

WILSON, Christopher. Vihuela Music of the Spanish Renaissance. Virgin Records, 1990. 


\section{INTERNET}

CEIA, Carlos. Paródia. Disponível em:

<http://www2.fcsh.unl.pt/edtl/verbetes/P/parodia.htm>. Acesso em: 7 jul. 2009.

; AFONSO, Maria de Lurdes. Pastiche. Disponível em:

<http://www2.fcsh.unl.pt/edtl/verbetes/P/pastiche.htm>. Acesso em: 7 jul. 2009.

CROUCH, Simon. Bach Cantata Listener's Guide: Mer hahn en neue Oberkeet (We have a new squire), 1999. Disponível em:

<http://www.classical.net/music/comp.lst/works/bachjs/cantatas/212.php>. Acesso em: 24 fev. 2009.

GABLER, Paul. La Folia: a musical cathedral. Disponível em:

<http://members.chello.nl/folia/index.html>. Acesso em: 15 set. 2009.

MOORE, Michael. Program Notes, 2005. Disponível em:

<http://www.mcchorus.org/prognt26.htm>. Acesso em: 9 mai. 2009.

MORAIS, Manuel. A nova música antiga: sobre a nossa Folia. Disponível em: <http://novamusicaantiga.blogspot.com/2005/06/3-sobre-nossa-folia.html>. Acesso em: 29 out. 2008.

ORTIZ, Diego. Tratado de glosas sobre clausulas y otros géneros de puntos en la musica de violones, Roma 1553 de Diego Ortiz (c. 1519-c. 1570). Disponível em:

<http://www.terra.es/personal/joanvips/ortiz.htm>. Acesso em: 29 out. 2008.

OTERI, Frank J. Manuel Ponce, 2009. Disponível em:

<http://www.peermusicclassical.com/composer/composerdetail.cfm?detail=ponce>. Acesso em: 21 mai. 2009.

RILM - Répertoire international de littérature musicale: abstracts of music literature. Disponível em: <http://web28.epnet.com>. Acesso em: 15 nov. 2005.

RESIDA, Wanita. The Early Folia. Disponível em:

<http://www.xs4all.nl/ wresida/homepage/earlyfolia.html>. Acesso em: 01 mai. 2009.

REYES, Julio Sánchez. Cantata 212: Tenemos un nuevo soberano (Cantata campesina), 2007. Disponível em: <http://www.cantatasdebach.com/212.html>. Acesso em: 21 mai. 2009.

SISMAN, Elaine R. Variations. In: Grove Music Online. Oxford Music Online. Disponível em: <http://www.oxfordmusiconline.com/subscriber/article/grove/music/29050pg8>.

Acesso em: 28 abr. 2009. 
SOLOMON, Larry J. Symmetry as a Compositional Determinant: A description and analysis of the various types of symmetry that occur in music. 1973, revised 2002.

Disponível em: <http://solomonsmusic.net/diss.htm\#Preface〉. Acesso em: 19 jul. 2009.

SWARTZ, Luke. An introduction to J.S.Bach Cantatas, 1998. Disponível em:

<http://www.geocities.com/Vienna/2547/aboutsc.html>. Acesso em: 07 jul. 2009.

. Bach's Christmas Oratorio: Oratorio? Original? Regardless - A

Masterpiece. Disponível em:

<http://www-cs-students.stanford.edu/ lswartz/xmas_oratorio.pdf >. Acesso em: 07 jul. 2009.

ZANON, Fábio. A Arte do Violão: Programa III - Andrés Segovia: Gravações 1927-1939. Disponível em: <http://aadv.radio.googlepages.com/zanon_aadv-03.html>. Acesso em: 26 abr. 2009. 


\section{FILMES}

1492: The Conquest of Paradise. Direção de Ridley Scott. Los Angeles: Warner Brothers, 1992. 1 DVD.

BARRY Lyndon. Direção de Stanley Kubrick. Los Angeles: Warner Brothers, 1975. 1 DVD. 